

\section{LIVED RELIGION AND GENDER IN LATE MEDIEVAL AND EARLY MODERN EUROPE}

This study is an exploration of lived religion and gender across the Reformation, from the 14th-18th centuries. Combining conceptual development with empirical history, the authors explore these two topics via themes of power, agency, work, family, sainthood and witchcraft.

By advancing the theoretical category of 'experience', Lived Religion and Gender reveals multiple femininities and masculinities in the intersectional context of lived religion. The authors analyse specific case studies from both medieval and early modern sources, such as secular court records, to tell the stories of both individuals and large social groups. By exploring lived religion and gender on a range of social levels including the domestic sphere, public devotion and spirituality, this study explains how late medieval and early modern people performed both religion and gender in ways that were vastly different from what ideologists have prescribed.

Lived Religion and Gender covers a wide geographical area in western Europe including Italy, Scandinavia and Finland, making this study an invaluable resource for scholars and students concerned with the history of religion, the history of gender, the history of the family, as well as medieval and early modern European history.

Sari Katajala-Peltomaa is Senior Research Fellow at the Academy of Finland Centre of Excellence in the History of Experiences at Tampere University, Finland. She specialises in late medieval hagiography and especially in canonisation processes. Her publications include Demonic Possession and Lived Religion in Later Medieval Europe (2020).

Raisa Maria Toivo is Professor at Tampere University and the Academy of Finland Centre of Excellence in the History of Experiences at Tampere University, Finland. She specialises in history of early modern religion, gender, family and court records. Her publications include Faith and Magic in Early Modern Finland (2016). 


\section{Themes in Medieval and Early Modern History Series Editor: Natasha Hodgson, Nottingham Trent University.}

This is a brand new series which straddles both medieval and early modern worlds, encouraging readers to examine historical change over time as well as promoting understanding of the historical continuity between events in the past, and to challenge perceptions of periodisation. It aims to meet the demand for conceptual or thematic topics which cross a relatively wide chronological span (any period between c. 500-1750), including a broad geographical scope.

\section{Florence in the Early Modern World}

Nicholas Baker and Brian Maxson

\section{Dynastic Change}

Legitimacy and Gender in Medieval and Early Modern Monarchy

Edited by Ana Maria S. A. Rodrigues, Manuela Santos Silva

and Jonathan $W$. Spangler

\section{The Origins of the Consumer Revolution in England}

From Brass Pots to Clocks

Joanne Sear and Ken Sneath

\section{Lived Religion and Gender in Late Medieval and Early Modern}

\section{Europe}

Sari Katajala-Peltomaa and Raisa Maria Toivo

\section{Cultures of Law in Urban Northern Europe}

Scotland and its Neighbours c.1350-c.1650

Edited by Jackson W. Armstrong and Edda Frankot

For more information about this series, please visit: www.routledge.com/Themesin-Medieval-and-Early-Modern-History/book-series/TMEMH 


\section{LIVED RELIGION AND GENDER IN LATE MEDIEVAL AND EARLY MODERN EUROPE}

Sari Katajala-Peltomaa and Raisa Maria Toivo 
First published 2021

by Routledge

2 Park Square, Milton Park, Abingdon, Oxon OX14 4RN

and by Routledge

52 Vanderbilt Avenue, New York, NY 10017

Routledge is an imprint of the Taylor E Francis Group, an informa business

(C) 2021 Sari Katajala-Peltomaa and Raisa Maria Toivo

The right of Sari Katajala-Peltomaa and Raisa Maria Toivo to be identified as authors of this work has been asserted by them in accordance with sections 77 and 78 of the Copyright, Designs and Patents Act 1988.

With the exception of the Introduction, no part of this book may be reprinted or reproduced or utilised in any form or by any electronic, mechanical, or other means, now known or hereafter invented, including photocopying and recording, or in any information storage or retrieval system, without permission in writing from the publishers.

The Introduction of this book is available for free in PDF format as Open Access from the individual product page at www.routledge.com.

It has been made available under a Creative Commons Attribution-Non Commercial-No Derivatives 4.0 license.

Trademark notice: Product or corporate names may be trademarks or registered trademarks, and are used only for identification and explanation without intent to infringe.

British Library Cataloguing-in-Publication Data

A catalogue record for this book is available from the British Library

\section{Library of Congress Cataloging-in-Publication Data}

Names: Katajala-Peltomaa, Sari, author. | Toivo, Raisa Maria, author.

Title: Lived religion and gender in late medieval and early modern Europe / Sari Katajala-Peltomaa and Raisa Maria Toivo.

Description: Abingdon, Oxon ; New York, NY : Routledge, 2021. | Series: Themes in medieval and early modern history | Includes bibliographical references and index.

Identifiers: LCCN 2020025642

Subjects: LCSH: Europe-Religion-History. | Europe-Religious life and customs-History. | Men-Religious life-Europe-History. | Women-Religious life-Europe-History.

Classification: LCC BL689 .K38 2021 | DDC 274.06-dc23

LC record available at https://lccn.loc.gov/2020025642

ISBN: 978-1-138-54455-0 (hbk)

ISBN: 978-1-138-54458-1 (pbk)

ISBN: 978-1-351-00338-4 (ebk)

Typeset in Bembo

by Apex CoVantage, LLC 


\section{CONTENTS}

List of figures vii

List of maps viii

Acknowledgements ix

Chronology $x$

Introduction to medieval and early modern experiences

of gender and faith 1

Lived religion, lived gender 2

Experience: from lived reality to analytical category 11

Medieval and early modern Europe 14

The structure of the book 16

Bibliography 21

1 Lived religion and lived gender in family life

Saint Thomas' virgin in the tavern 25

Husband and wife 35

Married life in practice 39

The violent witch, his whoring sister-in-law and their grieving mother 45

Bad and holy mothers, caring and punishing fathers 49

Conclusions 53

Bibliography 58

Unprinted source material 58

Printed source material 58

Literature 58 
vi Contents

2 Gender in public devotion $\quad 65$

Making the private visible: pilgrimages 66

Manhood and masculinity as lived practice of religion 75

Lay people talking about religion 86

Conclusions 88

Bibliography 92

Unprinted source material 92

Printed source material 92

Literature 92

3 Spirituality, sinfulness and gender

Mother of God and other holy virgins: body and piety 98

The lay Marys: women religious 105

Vade diabolo - go to the Devil! 108

Demonology, witchcraft and gender 115

Sin and faith embodied 121

Conclusions 125

Bibliography 134

Unprinted source material 134

Printed source material 134

Literature 134

4 Conclusions: structures of experiencing gender and religion from the medieval to the early modern period

Index 
FIGURES

0.1 Religion as experience 


\section{MAPS}

0.1 Locations of the major cases analysed in Lived Religion and Gender in Late Medieval and Early Modern Europe 


\section{ACKNOWLEDGEMENTS}

This project can be claimed to have started in January 1999 when we began working with our doctoral dissertations and shared an office. Ever since then we have discussed, pondered and argued about gender and religion - with each other but also within ourselves. This is no wonder since so much has changed in these fields of research during this time. Luckily, we have not been alone in these discussions but have been blessed with colleagues sharing their thoughts and ideas with us. Clearly enough, the debt of gratitude has grown enormous during these years. Without naming people who may not want to be named, we acknowledge that we have benefitted from discussions held both within our Tampere University history community, especially at Trivium - Tampere Centre of Classical, Medieval and Early Modern Studies, as well as elsewhere in conference and network circuits.

Our work has been generously funded by the Academy of Finland, most lately in the form of the Academy of Finland Centre of Excellence in the History of Experiences (HEX) at Tampere University, and Raisa's Academy Fellowships project 'Catholic Reformation in Lutheran Sweden'. We thank the Academy for making our work possible, and HEX, for providing an encouraging and critical research community where we have been able to develop our conceptual and theoretical standpoints. We thank Mathew James for checking the language of the book and Routledge for their patience during this project and for accepting our book for publication.

Finally, we take this opportunity to acknowledge each other. While Sari is an expert on the medieval period and Raisa on the early modern, the whole of this book is more than the sum of our two bits of knowledge put side-by-side. Every sentence and every thought in this book should be credited to - or blamed on - both of us equally. 


\section{CHRONOLOGY}

$1215 \quad$ Fourth Lateran Council

1219-1223 Caesar of Heisterbach writes Dialogus Miraculorum

1220s Birth of Mendicant orders

1234 Canonisation becomes a papal privilege

1245 First Council of Lyon

1274 Second Council of Lyon

1299 The Ottoman Empire is founded

1307 Canonisation process of Saint Thomas Cantilupe

1309-1376 The Avignon Papacy

1311-1312 Council of Vienna

1315-1317 Great Famine in Northern Europe

1318-1319 Canonisation process of Saint Clare of Montefalco

1325 Canonisation process of Saint Nicholas of Tolentino

1337-1453 Hundred Years' War

1347 The University of Prague is founded

1347-1352 Black Plague in Europe

1371 Canonisation process of Charles of Blois

1374-80 Canonisation process of Saint Birgitta of Sweden

1378-1417 Great Schism

1382-1390 Canonisation process of Urban V

1397 The Kalmar Union of kingdoms of Denmark, Norway and Sweden is formed

1414-1418 Council of Constance

1417 Canonisation process of Brynolf of Skara

1417 Canonisation process of Nicholas of Linköping

1420s Prince Henry the Navigator (of Portugal) starts his expeditions

1431-1445 Council of Basel, Ferrara and Florence 
1455-1487 Wars of the Roses in England

1474-1477 Canonisation process of Catherine of Sweden

$1478 \quad$ Establishment of the Spanish Inquisition

$1486 \quad$ Malleus Maleficarum

1512-1517 Fifth Lateran Council

$1517 \quad$ Martin Luther at Wittenberg and 95 theses

1521 The Kalmar Union was disestablished

1523 Gustav Vasa elected King of Sweden

1524-25 German Peasants' War

1527 Protestant Reformation of Sweden begins

$1509 \quad$ Henry VIII of England ascends throne

1545-1563 Council of Trent

1562 St. Teresa of Ávila founds the monastery of St. Joseph, which became the order of Discalced Carmelite Nuns

1562-1598 Wars of Religion in France between Protestants and Roman Catholics

1598-1685 Edict of Nantes

1622 Canonisation of Saint Teresa of Ávila

1596-1597 Cudgel War in Finland

1616-1648 Thirty Years' War

1620-46 Trials for Rosary practices in Finland

1634 Founding of the French Academy (Académie Française)

1642-1651 The English Civil War

1666-70 Witch trials in Åland

1680s Trials for Saints' day celebrations in Finland

1690s Radical Pietists in Finland

1690s Stories of the Sawo Family

1695-1697 The Great Famine in Finland 
$\Leftrightarrow$ Taylor \& Francis Taylor \& Francis Group http://taylorandfrancis.com 


\section{INTRODUCTION TO MEDIEVAL AND EARLY MODERN EXPERIENCES OF GENDER AND FAITH}

The pre- and early modern world has often been described as an inherently religious one. There was no sphere of life where religion was irrelevant. Religion explained the basics of cosmology and society. Belief systems influence social relations even today, and in the medieval and early modern eras, religious ideas shaped some of the most important secular institutions as well as the overall social theory: the three estates were God-ordained with specific duties, and the idea of the two swords - that is, religious and secular power governing the world - was well established (even if constantly debated) by the Late Middle Ages. As such, religion was played out within the web of power relations inherent in societies. In addition, religion stipulated times of work, worship and leisure for everyone; it instructed what people were supposed or allowed to eat and when, and how, they lived, woke up and went about their daily tasks. Furthermore, religion justified social hierarchies, relationships of power and taxation, economic relationships, and politics and warfare. There were, however, many different interpretations of how exactly religion's demands were to be interpreted. Everyone had their own opinions about which of the many aspects of religious or more mundane life was to be given priority in any situation. More importantly, the relationship between religion and mundane private or social life was not one-way. Rather, religion developed in society to meet society's needs, and society developed in a religious culture that guided both expectations or aims and the means to meet them.

This book has two thoroughgoing themes that we intend to investigate from the late medieval period (ca. the 14th century) to the early modern period (until ca. the 18th century). These themes are religion (or faith) and gender, both of which we also understand in a specific way, as lived and experienced. The meaning of these two concepts, religion and gender, has changed in time, space and culture: people in the 14th century understood them differently from those of the 
Reformation period and from what we do today. In the medieval and early modern period, they were evolving processes, not fixed categories. As experienced and lived, they were both individual and shared, and thereby they created the bonds that bound individuals to their communities and ultimately formed societies. Religion created the sense of belonging essential for fostering connectedness within communities. Religion and gender also offered a means of engagement, for example in collective ritual participation. As lived and experienced, religion and gender were also always meaningful and important. They had tangible confluences in people's lives and the ways societies were structured - if they did not, religion and gender were not lived, but remained theoretical, which we are not interested in here. Rather, this book will show people investing energy, time and a considerable amount of emotional, social and economic resources in matters of religion and gender - not, of course, for nothing, but because they found this investment at least potentially productive.

\section{Lived religion, lived gender}

There have been numerous attempts in the last four decades to shed light on the history of popular religion as opposed to official theology and highflying ideology. This move reflects the democratic idea that the 'popular' must have had more practical importance for ways of life, economic choices and even political acts than theological jargon, which the not-so-well-educated nobility and uneducated 'real people' probably understood and cared for as little in the medieval or early modern period as we do today. Trying to get at 'popular' conceptions of religion and faith as separate from what theologians thought or taught - to shift the focus from what a few men thought to what many people did - has led to a dichotomous still-life picture still with often inherently judgemental or devaluative underpinnings. Another problem has been that the members of the populace rarely sat down to write coherent explanations of how they saw their religion. Rather, they went from day to day conducting their lives. Their thoughts on religion were generally only recorded when the authorities tried to pin them down and control them, for example in catechism hearings or church or secular court investigations of religious matters or offences. Such situations are likely to emphasise the dichotomy between the 'popular' and the 'elite(s)'.

Rather than recording what they thought about religion and faith or gender, people lived out their concepts in daily life. This process of living one's life in a way that reflects concepts of religion and gender - in short, whatever they did: signs, gestures and bodily practices - is what this book uses as a channel to access medieval people's concepts of religion and gender. We approach them as normal and inseparable parts of the day-to-day lives of lay people.

We have decided to use lived religion ${ }^{1}$ as our conceptual tool. Lived religion is not a particularly new concept. La religion vécue was used already by French social historians in the 1970s, although it originally meant largely the same as popular religion in the English-speaking world. Nevertheless, La religion vécue emphasised 
the impact and influence of faith and belief in people's daily lives, which later came to denote the essential core of 'lived religion'. ${ }^{2}$ In the anglophone sphere, lived religion was first adopted and developed by the 20th-century US historians and religious anthropologists Robert Orsi, David Hall and Meredith McGuire. The essential starting point was the observation that people did not adopt religious or theological systems in their coherent totality, nor as given, but rather they picked and chose as if from a buffet table. Hall, Orsi and McGuire thought this was an element of modern religion, but since their time, many historians of the medieval and early modern have pointed out that the people of those eras did the same. It was nevertheless important for lived religion scholars, especially perhaps for the historians, that not every action qualified as lived religion: it had to be a purposeful and structural - ritualised - action through which the community or the church defined what it was to be religious or believed. As such, lived religion emphasised practices, intentionality and orientation. ${ }^{3}$

As far as medieval and early modern societies are concerned, it is much more difficult to separate intentional or purposeful ritual religiosity from the less conscious and less directly religious. The spheres of the religious and the secular were inexorably intertwined and entangled. Faith was part of mundane life. We see religion essentially as an element of daily life, a way to live, interact and participate in one's community. For the book at hand, the links between religion and daily life are essential, and we focus on how people used religion in their communal interaction when fulfilling their duties as parents, husbands and wives, and members of the community. The term 'religion' as we use it here does not refer to a single creed or a set of beliefs as defined by one institution; rather, it includes the multiplicity of religious cultures of the period. We aim to show variations in late medieval and early modern versions of Christianity in different strata, in rural and urban cultures, and in trade and political cultures.

We wish to explore how religion worked as a medium between various levels of society, and this book will discuss dogma, theory and institutions as well. So, our focus is not solely 'from below': theological ideas and institutions were inherent elements in religion, and we do not deny the importance of elite teaching or political relations in the study of religion: quite the contrary, they were present in lived religion as integral background elements. However, we see the essence of religion as an active dynamic process; it created a performative space and gave meaning to people's experiences. Hence, religion was not solely defined by the clerical elite, nor was it a superstructure of culture bestowed from above that was deliberately, mundanely or even cynically used to achieve the goals of the elite. Lived religion is formed at the core of communal life, where ideas and religious concepts are experienced, and they are expressed by 'living them out' in everyday life, performance and ritual.

We hope to avoid the dichotomies between elite and popular and theological and mundane. Boundaries were fluid and did not always run according to accustomed lines. For example, allegations of some clergy being illiterate - i.e. not understanding Latin - are not unknown in the Middle Ages, while some laymen 
were literate in both the medieval and modern sense. Clearly enough, there were differences in terms of learning and comprehending the basics of the faith according to one's social status and background, but in our view strict categorisation does not seem to add much to the understanding of the complexity and plurality of medieval and early modern religiosity, although admittedly they do offer tools for constructing neat narratives. Therefore, this book will shift back and forth between theology and church politics, religious teaching and lay life in a way that might be considered eclectic. The intention here is not to provide a systematic categorisation of who believed what, but rather to follow how ideas, events and people influenced other ideas, events and people. Lived religion in the lay context did not have the coherent and ordered structure of a learned dogma, nor was it mere outward ritual. Religion as a lived practice was a social process created by the participants' experiences, expressions, senses, emotions and performances. It meant 'living out' sometimes unexplainable concepts of the world and one's relations with the sacred and the supernatural.

The 'living out' of religion and faith was connected to theory and theology, but it was much more situated in people's own personal lives and the local and cultural communities. The living out of the concepts of faith, magic and superstition not only reflected but also created one's relationship with the sacred and supernatural powers, not to mention one's relationships with other people in the community. However, magic, too, requires faith in its effectiveness: it requires belief in there being a higher power that can be coerced into interaction. Relationships with the sacred and supernatural powers included amicable collaboration as well as the acting out of tensions and conflict. Psychologically, this means that one was more likely to describe one's own relationship with the sacred as faith - and to experience it as such as well: the same deeds would be considered faith or diligence and carefulness when performed oneself, but as ritual magic when performed by others. Magic, despite its alluring potential, seems to have been something which one would suspect others of. Moreover, superstition was always a label imposed from above. The complexity of the lived experience of the concepts prevents narrow definitions at the outset: indeed, the terms 'faith', 'magic' and 'superstition' will inevitably evolve throughout this study, and one of the aims of this book is to see how.

Religion was not merely spirituality either, even if it offered spiritual experiences for the participants. The performance of many religious rituals was private and individual while also partly public, communal and shared. In the surviving evidence, the aspect of publicity, communality and sharedness dominates indeed, communality has been considered one of the key elements of traditional pre-modern religion. Orthopraxis - visible, public deeds, like confessing one's sins yearly and taking the communion; praying in a certain way; and performing pilgrimages, penitential practices and other rituals linked to the calendar and agricultural year with the rest of the community - was a method of ascertaining one's position within community. Instead of being hollow ceremonies or superficial forms, as some traditional criticism would have it, such acts were essential 
elements of lived religion; they created experiences and emotions, enhanced the community's coherence and explained cosmological and social hierarchies. Religious practices were a means of interacting with one's community, and religion was an element of shared identity. The practices of lived religion could work both ways; they could enhance social cohesion but also lead to the disintegration of the community and social exclusion. Religion could break up communities by delineating the boundaries between 'us' and 'them'. ${ }^{4}$

The dominance of communal practices in the source material may also reflect the fact that few lay people wrote down descriptions of their religious sentiments and experiences unless they had an audience in mind. Furthermore, some themes were unspeakable. A lack of faith - and through it, despair - was thought of as a sin that threatened both the individual and the whole community; it was a taboo and therefore unlikely to be discussed by the laity. Consequently, at least two parties had to be involved for any historical source material to be created. During the era of religious change discussed here, ideas of proper dogma and praxis were no longer understood as fixed and stable; rather, certainty was replaced by the experience of doubt and hesitation. We argue that negotiations on and between various social levels manifest the needs, aspirations and resistance behind religious change. The way people lived their religion was intricately linked with questions of the value of individual experience, communal cohesion and interaction, and power relations. Thus contextualised, the trials against people accused of heresy, witchcraft and superstitious practices can be treated as material on the religious life and sentiments of the wider culture. However, religious diversity and flexibility in accommodating different viewpoints and practices to the point of toleration seem essential in the religious atmosphere of the early modern era, which has nevertheless been termed the 'age of persecution'. Religion - as it was lived out in daily life and personal encounters with other people - was different from the dramatic disruptions of the witch hunts or the religio-political wars and massacres. ${ }^{5}$

One part of the interdependency of the religious and the social was the understanding of gender. Modern scholars have approached this interdependency in various ways. Gender historians have often treated gender as a social category that produces social hierarchies and relationships of power. This was highlighted in research focusing on medieval misogyny as reflected in clerical rhetoric, which for the major part dominated the first works on medieval or early modern women. Since women do not particularly stand out in many sorts of medieval source material, the first phase of research was dedicated to finding women in the sources. Negative stereotypes - in addition to saints and queens, women with actual political power - were most easily found; the early phases of the study of medieval women were dominated by the opposite poles of hierarchy, depicting a black and white image of medieval gender order. ${ }^{6}$

Understood as a component of hierarchies and power relationships, gender was also a tool in researching medieval and early modern workshop production and profit division, trade and production, and household order and human 
reproduction. The first developers of medieval and early modern gender history theory were in fact economic historians. The questions that arose from this kind of understanding of gender concerned the exclusion of women from the labour market - especially skilled labour in the early modern period - and from the control of economic means of power, capital and the kind of labour that produced the control of resources. While women certainly worked in households, in care, and even in workshops, gender historians pointed out that their work did not give them power. Trends of explaining gender in the pre-modern at first emphasised either a deterioration of women's positions after the 'golden age' of the Late Middle Ages or a gradual embitterment of everything, gender included, with modernisation. Finally, the emphasis of gender historians, especially economic historians, settled on the notion Judith Bennett epitomises in her History Matters. She states that history shows a 'patriarchal equilibrium' where, despite many changes in women's experiences over the centuries, women's status vis-àvis that of men has remained unchanged - they are and have always been inferior and oppressed. Bennett claims that traditional historians continuously reject such terms as 'women's oppression', 'gender order' and 'gender hierarchy', instead favouring other concepts emphasising difference instead of inequality; this hides from sight the ongoing and major feature of all historical and contemporary societies: men's domination over women. ${ }^{7}$

In this framework of hierarchical gender relationships, religion often is seen as a tool of oppression and a major force of history that holds back both societies and women, preventing freedom, activity and subjectivity. Modern feminism has therefore long advocated secularisation in the hope that it would, with modernisation and rationalisation, bring racial, gender or economic equality. Nevertheless, as Joan Scott says in Secularism and Gender Equality, the hope that secularisation would bring equality did not work particularly well for nonmodern, non-western societies. This is becoming especially evident in globalisation and migration into western societies. In the west, too, secularisation failed to bring the hoped-for equality, whereas various religious and neo-religious movements have different kinds of feminist agendas. Especially for women who want to subscribe to a religion, a version of feminism that condemns religion may not be empowering. ${ }^{8}$

The need for a different kind of understanding of gender is especially visible if we look at pre-modern history or any kind of 'lived histories', histories that try to connect the messy stuff of individual people's action and agency to big pictures of societal structures, policies and ideologies. ${ }^{9}$ Studies trying to link ideologies and structures to individual or shared experiences tend to disrupt the neat narratives, descriptions of development or categorisations of analysis. Such studies often show that the modernist stance - where not only the rights and status but also the subjective self of a person depends on free will - may not be the best way to assess gendered agency in connection to religions or faiths where the subjective self can come into being and exist only as subordinated to (a) greater power(s). ${ }^{10}$ 
Historians of medieval and early modern religion have found Judith Butler's understanding of gender as a performance more fruitful than defining gender as a categorical power relationship. ${ }^{11}$ This approach allows for more culturally sensitive ways of dealing with gender also in contexts where human subjectivity was supposed to be always subjected to a higher power and where human power relationships were therefore by definition of less importance than those between humans and the Divine or transcendent. Therefore, God could be understood as a nurturing mother and monks as brides of Christ. ${ }^{12}$ We follow this lead and understand femininities and masculinities as a way of being and doing, as a matrix or net of qualities where the men and women - also those living in closeknit hierarchal societies - can choose to construct identities. Our aim here is to speak of masculinities and femininities in the plural, allowing for not only gradation and a continuum but also varying scales and directions. For us, then, gender is a lived and experienced process, not a category into which one must fit. Such a gender is not only a tool for research or a category to produce answers, it is also an open question that historians must seek answers to, and ultimately, a result of research. ${ }^{13}$

It is evident from the ample research on medieval and early modern source material that people of the time did not understand gender merely as biological sex. On the contrary, gender was socially and culturally constructed in a matrix of other qualities, such as age, lineage, marital status, wealth, occupation and a number of other hierarchies in workshops, schools, cloisters, marketplaces, fields and cattle sheds. Gender consisted of expectations, roles, practices and possibilities, which people in turn used, re-created and reinterpreted. This book will provide examples of such manoeuvring in various situations and points in time, with different people acting as agents.

The medieval world had its own gender theory, which was largely based on the Bible and the writings of early Christian moralists. The key narratives in this respect were Genesis and the doctrine of the fall, which categorised the gender hierarchy and characteristics of masculinity and femininity. Adam was created first; he was more important, the more perfect image of God. Eve, on the other hand, was created second, which reflected her rank in the hierarchy. Just as important was the fall: since it was Eve who succumbed to the temptation of the Devil, she was deemed to be the weaker vessel with less willpower, rationality and virtue. She was the Devil's gateway and the reason for mankind's fall from grace. $^{14}$

More importantly, this was no singular slip. Eve represented the whole of womankind, revealing its innermost qualities and faculties. Neo-platonic binaries associated men with rationality, logic and reason, and women with emotions, illogic and immorality. The basic hierarchy of genders and their categorisation was clear - except it was not. The Bible itself offers various sources for gender construction, showing it was fluid and inconsistent, and the later exegetical tradition added to the confusion, even creating contradictions. The Bible both affirms and contests gender hierarchy. ${ }^{15}$ To begin with, there are actually two 
different version of Genesis. The first one implies that man and woman were created simultaneously. The other, longer version tells how Eve was made out of Adam's rib. The position of Eve also caused widespread dispute: she was made second, but not from the foot, which would posit her clearly as inferior. She was not made from the head either, which would have made her superior. Indeed, did not the rib imply equality?

The fall was no easier to interpret. Yes, it was Eve who fell into temptation, but should not Adam, if he was indeed more rational and logical, have been stronger in resisting temptation? Could it have been that the sin of Eve was understandable, in a way? She was, after all, the weaker vessel that Adam was supposed to guard and govern. If so, the logical outcome of all this was that Adam's sin was graver.

Even the most misogynistic of moralists could not escape these dilemmas; the interpretation of Genesis and the fall was problematic and led to contradictory arguments. Sure enough, Eve was used as a prototype of Woman, a warning example in exempla, cautionary moral tales used in preaching to educate and entertain the audience. It was clear that every Christian was a potential sinner, and a considerable part of clerical rhetoric was targeted against the dangers of sin. Gendered stereotypes were a tool in this enculturation process. It has also been pointed out that exempla did not claim that all women were like this all the time; they merely showed what women were alike when they were sinful. A potentially more significant caveat is that gender was not the only hierarchy and power relation constructed by such tales. Recent works have shown that the misogynistic tales of women could have been a method to gain or claim control, acquire an elevated hierarchal position for the clergy, and recreate the proper order of society. ${ }^{16}$ Misogyny could have been just a tool to utilise within other societal discussions. Clearly enough, handy rhetorical tools are not mere coincidences. Rather, they reveal wider cultural expectations and social customs.

Gender was a complex matter in theological ponderings: the inferior position of women was based on interrelated physiological, mental and spiritual matters. Female corporeality was not only an aspect of physiology or an individual feature; its interconnection with spiritual matters made it a shared concern. Women and especially their bodies were connected with lust: as an inheritance of early Christianity and the desert fathers, medieval Christianity nurtured the idea of carnal desires arising from the flesh. The urge to repudiate earthly pleasures and see sexuality as a threat to the salvation of one's soul was prominent among patristic writings, where renunciation of the flesh and praise of ascetic ideals were crucial. For early Christian authors, carnality was the main cause of sinfulness, and women were more tightly bound to corporeality. ${ }^{17}$ However, medieval approaches to the body were neither simple nor straightforward, as has been reckoned by the numerous scholars working with the interconnection between gender, the body and religious practices. Especially in literary criticism, one may speak of a 'corporeal turn' because of the popularity and significance of this topic. These works have reassessed the dualism between mind and body. It has 
been shown that bodies - and in the context of late medieval religiosity, female bodies in particular - were ample vessels for the practice of penitence, abstinence and asceticism. The body could be a positive element in religiosity, and it could be a means to both salvation and damnation. ${ }^{18}$

The body was not only biological but also a malleable cultural construct. Female bodily perfection was thought to be achieved via chastity. In addition to a distinct sexual orientation, chastity was a constructed state that needed recognition. It was not just a physical category, since physical virginity did not ensure virtue. Conduct was a crucial element in its construction, and spiritual chastity was more important than its bodily analogue. Virginity and chastity were not necessarily identical. This made chastity also a hierarchical construction; the church insisted on authority in recognising and confirming its crucial components. ${ }^{19}$ To confuse things further, chastity was not a lack of desire but a way of redirecting it to matters of the spirit: the erotic could overlap with the spiritual, which had its clearest manifestation in the mystical marriage between the mystic and Christ. ${ }^{20}$

Chastity bound together corporeality and spirituality. Furthermore, these notions were manifested and created by affective elements. The production of emotions was an essential part of religiosity. The rhetoric of affectivity emerged first in the writings of the Cistercians in the 12th century and then spread to other orders and the laity, and it can be seen as an evident element in all literary genres from the 13th century onward. The use of emotions and affect was encouraged in devotional literature, contemplating Christ's passion and the Virgin Mary's grief at the loss of her son were constitutive. ${ }^{21}$ An increased focus on religious emotiveness promoted a greater emphasis on praising typically feminine virtues, such as weakness, humility and weeping. ${ }^{22}$ Since women were more carnal than men, their corporeality gave them easier access to identification with the suffering Christ. The misogynistic and patriarchal basis of culture that connected the feminine to weakness and emotion gave women the incentive and option to cultivate religion in a way that promoted their own way of practicing religion. The cultivation of affectivity turned the fabric of inferiorisation - misogynistic notions of women's uncontrollable emotionality - into practices of empowerment, shaping understanding of both gender and religion.

Chastity and affective elements were particularly pronounced elements in mysticism, but they were prevalent parts of later medieval culture and discussions of gender and religion in particular. These rhetorical constructions had implications in the lived practices of religion. Men, too, had to be humble and weak before God to be pious, while simultaneously all Christians needed to fight the feminine side of their nature, especially feeling of sexual lust.

Emotions and their production are shaped by the cultural and temporal context, for example by religious practices, and emotions, in turn, shape the communities, rituals and practices they are produced within. The word 'emotion' did not exist before the late Middle Ages, and the concept was understood differently from contemporary notion. Especially in the religious context, emotions were 
comprehended as 'movements of the soul' leading to either salvation or damnation. In addition to the moral component, they included an important inner part. ${ }^{23}$ We use emotion as an analytical category without an intention to advocate ahistorical human universals. For us, emotions are constituents of 'experience' since they were expressed, produced and observed collectively.

The gender theory of medieval and early modern Christianity and its applications within daily life were unstable, leading to multiple gender identities. In the early modern period, especially in northern Europe, gender expectations gained a new emphasis based on Luther's ideas of one's social duties and occupation as a religious calling. Crudely speaking, this meant that everyone had been placed by God Himself into an earthly occupation, the fulfilment of which was not only a social duty but also a duty towards God and the best method any individual could have to worship God. Luther's ideology here was related to the abolition of closed religious orders - the monasteries and cloisters, as well as beguine and similar lay religious organisations - but it also meant a renewal of the connection of the mundane and the religious in terms of gender expectations, along with everything else. Marriage was obviously an important social institution during the Middle Ages, but in Luther's formulations it became a calling. When they were not widows or servants or children, women were presented as housewives and mothers and men as husbands and fathers. However, both also belonged to the classes of parishioners, listeners to the word of God and - in certain situations, like in household devotions - groups of religious teachers.

Sometimes the social construction of gender - situation by situation, in the matrix of other qualities that defined expectations and opportunities - showed that gender was not tied to biological sex in any simple or unambiguous way. Sumptuary codes restricted clothing and appearance according to birth and occupation, sometimes also according to ethnic origin or religion, and crossdressing was legally forbidden in many European countries. Nevertheless, stories of women presenting as men and men presenting as women were frequent enough to show that the idea was far from surprising to medieval and early modern communities. Religious vocabulary also abounds with descriptions of people experiencing a gender change or giving up their gender identity as a mode of ultimate religious experience, true union with Christ, and humbleness towards God and creation. Religious texts let us encounter men who feel like women, and women who have the hearts of men. This may lead one to question whether the long history of heteronormativity is really so long, as early modern and medieval people understood gender in less binary terms than we think they did. It also leads us to ask whether historians could conceptualise medieval and early modern gender in ways that better accommodate the questions that arise from our current society and the collision of new feminism, LGBT, and non-cis sexuality and gender with conservative ideologies, macho cultures and religions that are today labelled as 'traditional'. This book suggests that this need may lead to a concept of lived gender - gender that is performed but also structural - or perhaps a multitude of gender performances that create societal structures. This 
kind of approach enables us to evaluate critically the modernist view of religion as deterring progress and independence, especially that of women. Pre-modern histories and 'lived religion' history, and perhaps 'lived histories' in general, suggest that to acquire a more accurate and sensitive understanding of the connection between religion and gender, gender needs to be approached as an open question rather than as a category.

\section{Experience: from lived reality to analytical category}

We approach 'experience' on three different levels. First, it is part of social reality, what happens to people; second, it is a cultural process to explain and to give meaning to what happens; and third, it is an analytical category to analyse the first two. For us, 'experience' is both a method as well as a result. We ask how experiences were constructed within and by religion and how they, in turn, contributed to the construction of a gender as lived practice.

Works on lived religion often describe their findings as lived experience or even religion as lived experience. This is meant to emphasise the practicality and pragmatic nature of lived religion: it consists of real people's experiences in real life, how things really were as opposed to how things were supposed to be or how they were hoped to be in prescriptive, legal, ideological or didactic materials. Nevertheless, 'experience' is not to be understood as a self-defining collection of anecdotal 'evidence', nor anything universal or a-historical. Rather, experience is, for us, a culturally and situationally bound social process.

Experience has been defined in various other disciplines, as well as in history. The definitions are slightly different, but they point to similar directions. Among philosophers, the definitions approach the concept from two directions at the same time. First, experience is understood as a subjective feeling or understanding of the world or the events in the world, guided to an extent by real facts and events but also, and to an even greater extent, by subjective prejudice and expectation. At the same time, experience is the process of encountering the world that is intersubjectively shared by oneself and other people, and a test of one's subjective understanding against the shared concepts. ${ }^{24}$ In the current post-truth or post-factual culture, this type of understanding of the world is often evoked as a kind of alternative evidence: it matters not whether it was 'actually' or factually true, people's experience of the success of a president or an encounter with social workers is seen as valid regardless. The unclear relation between experience and subjectivity - or indeed, experience, fact and fiction - is made explicit when the concept is used in literature studies and the study of different art forms that explicitly work on fiction and even speech communication - fields that are interested in how the art work or speech act can make the audience 'feel' or 'experience' something. ${ }^{25}$

In historical study, the focus is less clearly on the purposeful performance of communication: a vast number of factors in the material or social world can trigger experiences. Therefore experience is less self-evidently fictional, and it may be easy to forget that it is still interpretative. Experience may reflect physical and 
social or cultural realities in the lives of those who experience, but it also reflects the ways people make sense and explain those realities to themselves and to others. The explanations and interpretations given will not only influence each other and the ways people make sense of what has happened to them but also guide what people expect to happen to them in the future. These expectations, in turn, may guide people's behaviour and expectations, and thereby experiences also have an effect on what actually happens to individuals and groups of people. Moreover, new experiences will add to the framework in which people explain their pasts: therefore, their explanations will evolve and experiences will keep adjusting, too. Historians - who generally try to avoid overly restrictive definitions - might describe experience as mental experimentation with and observation of the world that always includes an attempt to explain and interpret the observations made. As such, experience is an ongoing social, contextual and situationalised process.

As pointed out by Joan Scott during the linguistic turn, ${ }^{26}$ if experience is allowed to remain anecdotal, it really is just a collection of random examples, and it provides no more evidence or argument of the real past than general 'whataboutism'. A similar critique was presented by Gareth Stedman Jones regarding the early modern period, especially pointing out, for example, that though one of the early modern meanings for (religious) experience given by the Oxford English dictionary was conversion, the Reformations in England and Sweden are poorly explained with any reference to the conversion experiences of Henry VIII of England and Gustav Vasa of Sweden. ${ }^{27}$ Both Scott's and Jones' critiques highlight the need to ask what experiences are we talking about exactly. To be useful, experience needs to be conceptualised analytically. ${ }^{28}$ As such, experience is understood to be something more than just a singular occurrence in an individual's life; it is something shared, and it encompasses emotions and corporeal and sensory elements and memories. An experience is something meaningful, and this process of giving meaning is the focal point. The authentic experiences of illiterate lay people of the medieval or early modern era can, at best, be accessible only in mediated form. Indeed, 'experience' is not necessarily something that actually happened to a certain individual at a certain point in time; it can also be something evoked, provoked or imagined, providing a bridge between structures, ideology and individual and communal agency.

The above understanding of experience as a social mechanism is modern, and made to serve a modern historian, but it is not whole foreign to the medieval and early modern not objects of our study. The Oxford English Dictionary defines experience as both a noun and a verb. As a noun, the meanings of the word start from the later Middle Ages: an experience can mean an event, the action of putting to the test (1393); a procedure or operation performed in order to ascertain or illustrate some truth, an experiment (1384, now obsolete), Proof by trial and practical demonstration (1393, now obsolete), Observation of facts or events (1377), A state or condition viewed subjectively, What has been experienced (1607), Knowledge resulting from actual observation or from what one has undergone (1553). As a verb, the meanings are slightly younger: to experience means to make trial or experiment of, to put to the test 
(1541); to ascertain or prove by experiment or observation (1541); To have experience of, to feel, suffer, undergo (1588); To learn by experience (1586).

Two things are apparent in the definitions, as well as also in the corresponding German concept of Ehrfarung (vs Erlebnis): the first is the active and purposeful nature of the term, and the second is its process-like nature. Experience is not just something that exists or that one is given, it needs to be got and gained, produced even. As experience is produced, the observation of the world through one's senses - and the interpretation of that world through understanding and previous knowledge - also shapes one's expectations of the future. As these observations and interpretations are tested and shared with others through intersubjective communication, it is also possible - and, we believe, advisable - to pay attention to and analyse how they are produced, shared, controlled, appropriated, approved of or discarded. After all, they shape how people understand the world in which they - and we - live. While experience is based on both observation and interpretation, and while always communicated between humans, it is created not merely in language; it is an essential part of social reality. ${ }^{29}$

Experience is not only an object of study, however. It is also an approach and a method. As Barbara Rosenwein once noted about 'emotional communities' these same communities could also be a lot of other things: families, groups of friends, certain political circles or something else, it was only the historians' interest in emotion which turned them into emotional communities. ${ }^{30}$ In our understanding of experience, the same is true, and not merely about communities, but the rest of history as well. Experience is an approach that guides what we think is interesting, and also in how we see it. For us, experience gives a holistic and intersectional approach to the past: as a process and something that is done by people instead of given to them completed. Logically, it follows that experience cannot be looked at only as a top-down process, nor a from-below-type of social history: experience is a way to draw attention to the in-between communication, negotiation and transmitting of physical realities and interpretations thereof. Since it looks at both ideals and realities, communication and thought, it is also by definition a trans- or multidisciplinary way of doing history.

Methodologically, we hope that the nature of experience as a social process will give us a way to connect the micro and macro levels in historical observation, investigation and explanation, and bridge the gap between empirics or source material and theory or explanation and generalisation. In the following, we will concentrate on what people do, to get at how they think and experience things that they do not talk about. Since experience is action as well as an analytical category, it can be used to study the forms of action and interaction that eventually create both individual self and the community. But as a contextual and situational phenomenon and approach, experience must always be a genuinely open question throughout time and space. This is what we hope to bring out with a longue durée discussion crossing the traditional boundary between medieval and early modern, and by taking a variety of geographical locations with different cultural and social preferences in each point of time. 


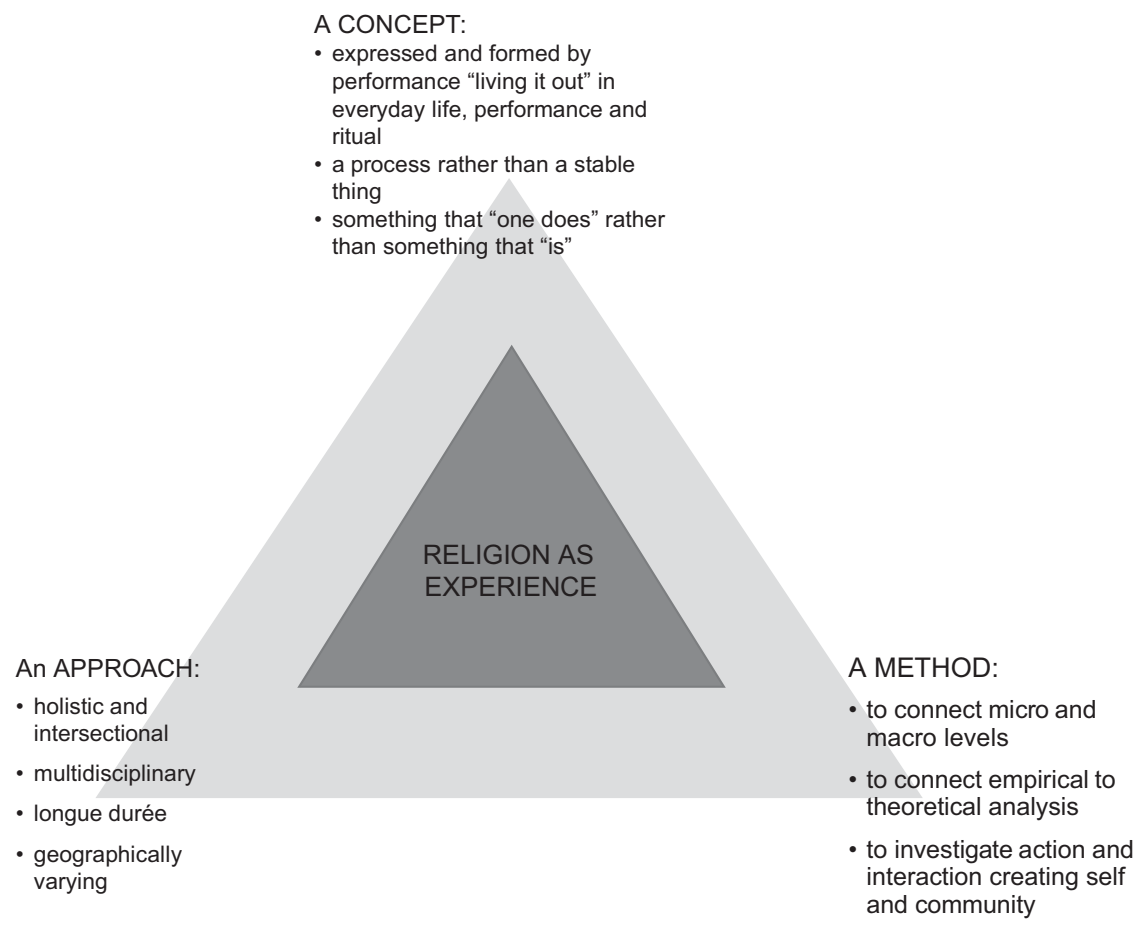

Sari Katajala-Peltomaa, Raisa Maria Toivo

FIGURE 0.1 Religion as experience

Source: (C) Sari Katajala-Peltomaa, Raisa Maria Toivo

\section{Medieval and early modern Europe}

The purpose of this volume is to investigate the religious and gendered experiences of lay people from the late medieval period to the early modern era - that is, across the traditional period boundaries of the Renaissance and the Reformation. We look for change in time, but even more so, we end up showing continuities across the divide between the periods. Indeed, one of the results of this book is that we end up showing that things lived and experienced are at the same time more flexible to adaptation and slower to profound change than any of the written analyses of these changes - either by contemporaries or by later sociologists or historians are apt to show. The lived and experienced are at the same time rooted in the momentary, contingent and changing situation, and in the basics of life, society and survival. They change radically only when the living conditions of people change equally radically. New kinds of wealth, innovation and disease entered the European universe at the break between the medieval and the early modern. However, most of the basic modes of life nevertheless remained the same in the agricultural milieu and even in the mostly small towns' inherently rural conditions. 
The Renaissance and the Reformation are among the crucial thresholds of the shift from the medieval to the early modern. The Reformation has been described both as an abrupt break that revolutionised (or ought to have revolutionised) thinking and religion in a very short time and as a long process over the centuries with phases of turmoil and crisis as well as gradual adaptation over time. The longer version has been termed the 'Long Reformation'. The critical tone towards what the Protestant Reformers would later label the failures of the papacy had become increasingly apparent in the areas of lay and regular piety and theology, and it manifested as a slowly forming nationalist critique of the papacy from the late 14 th century onwards. The Avignon papacy and the following schism can be seen as low points for the Church hierarchy, but disapproving voices against the practices of Renaissance popes grew in volume during the 15 th and 16th centuries. The need for modifications was also acknowledged within the Church, and attempts to achieve conciliar reforms in religious practice and theology were made throughout the history of the Church. ${ }^{31}$ Likewise, the religious changes continued, were reversed and acquired yet new directions in various locations across Europe for at least a century or more after the 'Wittenberg affair'. Other scholars have emphasised the different phases of the crises (rather than the phases of gradual adaptation and establishment) as constitutive of the changes, by discussing Reformations - Lutheran, Calvinist, English, Swedish, Counter-Reformation, Tridentine, people's and princes' - in the plural. ${ }^{32}$

We will be using both of these terminologies and both of the related emphases on where in society and culture, religious and cultural change took place. We acknowledge times of upheaval, but a large part of this book will showcase the importance of the ordinary and expected everyday in shaping, interpreting and establishing change. The everyday is when people have the time and means to create ritual and reinterpret it. The everyday is when some experiences of crises are either forgotten or institutionalised into new social orders. Crises may destroy societies, but in the everyday, societies rebuild themselves and choose new directions.

All of the above obviously affected gender order and the comprehension of masculinities and femininities, but the changes were not simple or straightforward. The interconnection of societal change and gender order has been a crucial question at least since 1977, when Joan Kelly published her seminal work 'Did women have a Renaissance?' Tellingly, the article was published in a compilation titled Becoming visible, as this was the era when women were emerging becoming visible - in both society and academic research. Kelly's main argument was that societal changes affect different people in different ways. We, too, focus on temporal changes, but we do not propose a simple evolution. Societal and cultural changes at the end of Middle Ages had an effect on various levels of society and various groups based on wealth, ethnicity and gender, but they were not straightforward, simple or simultaneous. Since Kelly's article, however, not only have women become visible, so too have various forms of gender and sexual 
identity, the understanding of non-cis and non-binary gender, and LGBT rights. This has, however, not removed the need for this kind of research - quite the contrary. Now it is clear that we need a sharper lens to focus our view on these issues.

One of our methods of achieving this is the careful contextualisation and understanding of geographical and cultural nuances rather than the construction of one universalising discourse of gender and its temporal changes. Geographically, the book covers western Europe from Italy to the Nordic countries. A large part of the material we use is from Italy, England, Finland and Scandinavia, but various cases come from other areas in Europe. As this volume also covers the northern areas of Europe, it will offer some insights and viewpoints that are different from the usual canon of either late medieval or early modern European history, which concentrates on British, German and French areas or the Mediterranean. Especially during the Middle Ages, teaching and dogma created a universalising discourse, but the wide geographical setting enables us to see the nuances and fractures within it. On the other hand, the emerging nation states often form the confines of research, sometimes too rigidly and even anachronistically.

Comparative perspectives and cross-cultural analysis offer us the tools to scrutinise these boundaries, including in terms of if and how they had an effect on the concepts of feminine and masculine. Simultaneously, we acknowledge that histories of gender and religion in Europe were entangled with the histories of the rest of the world, as well as non-Christian faiths and religions within and outside Europe. Nevertheless, the reader should not expect this volume to provide an overview of everything even in European history, or even an equal amount of detail or generalisation for every European area. A detailed country-to-country overview is neither the purpose nor a possibility here. This book is not meant to be a conclusive 'History of the Reformation of Gender in Different Parts of Europe'. We will merely point to comparisons, contrasting notions and similarities in an attempt to gain a wider comprehension of how understandings of religion and gender interacted in the situated and contextualised changes of the everyday.

\section{The structure of the book}

The book has a two-fold strategy: we develop the concept of lived religion from the viewpoint of experiencing religion on various levels, from the institution of the church, control and dogma to daily life, work and family. Secondly, we combine our conceptual work on religion as lived practice into developing an understanding of gender in the intersectional context of religious experience.

The book combines conceptual development with empirical history. We use significant case studies - at least one medieval and one early modern in each chapter - and tell the stories of individual persons and groups of people, which we hope will make the book interesting and easy to read. However, we use them to make a point and to develop the concepts of lived religion and gender, and to compare the medieval and the early modern. Lived religion is explored via 


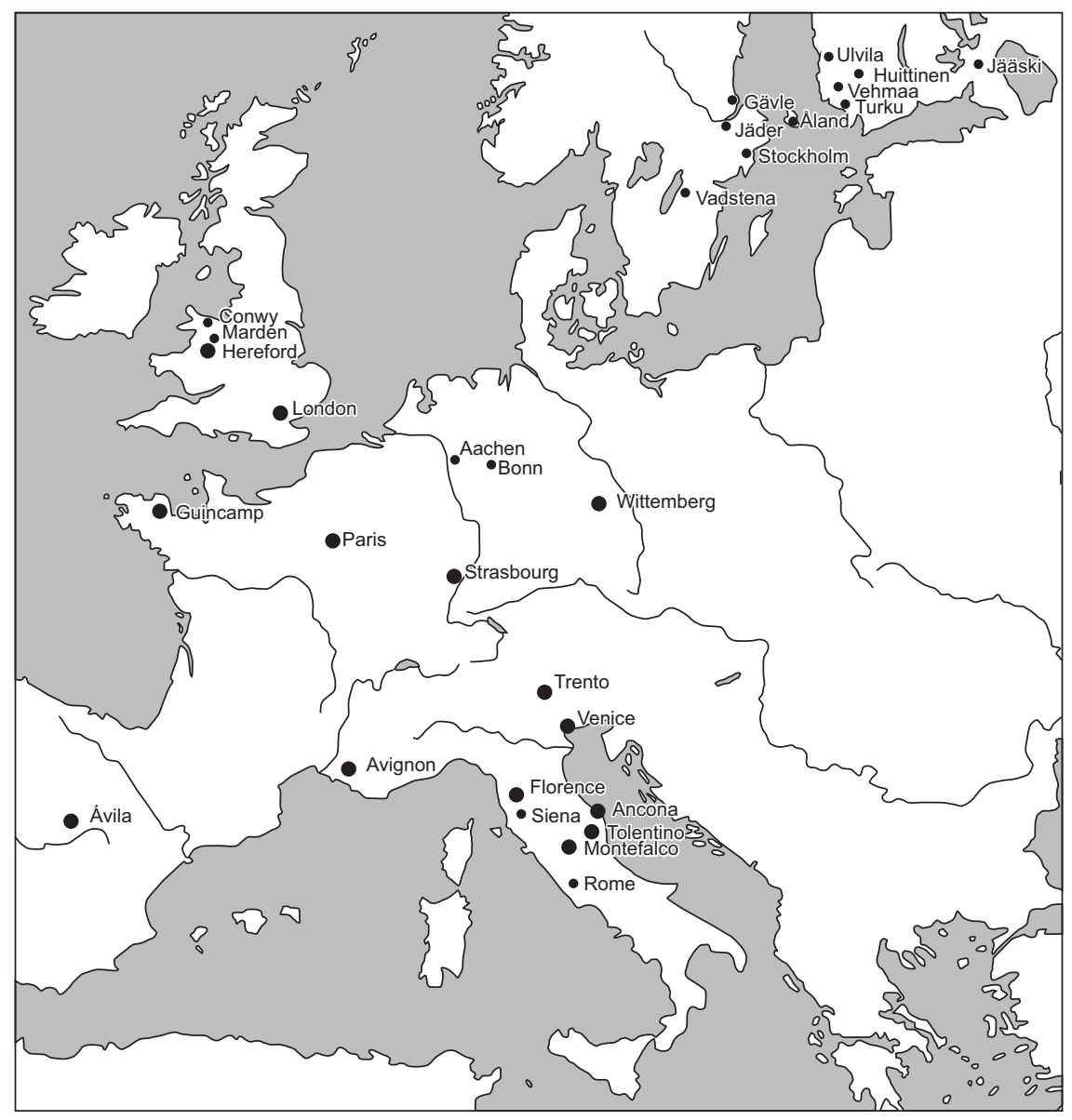

MAP 0.1 Locations of the major cases analysed in Lived Religion and Gender in Late Medieval and Early Modern Europe

Source: (C) Sari Katajala-Peltomaa, Raisa Maria Toivo

various themes, such as the Reformations, power, agency, gender, work, family, miracles and witchcraft. The book is divided into three main chapters, which discuss the interplay of gender and lived religion in different spheres of life, and a conclusion. Each chapter connects the source materials used for the historiography and conceptualisation of lived religion and lived gender.

Chapter 1 asks how religion and gender were performed and experienced in the home, household and family. Marriage was the basic unit of society in religious, legal and social theories as well as in the experiences of daily life. Being a wife and mother or a husband and father were roles society expected of its members - even during the celibacy-admiring Middle Ages. Parenting and taking care of one's household and dependants were religiously prescribed positions 
and moral responsibilities. Correspondingly, a major part of religious participation took place within homes and among family members and kin. Religion as a lived practice influenced the milestones in a person's life course, gendered parental roles and the socialisation of children, respectively; performing these duties formed the nucleus of lived religion. Familial and religious responsibilities, options and choices were amalgamated.

At home, women were often regarded simply as wives and mothers and men as husbands and fathers. This view is justified because most laypeople did indeed marry, and the marriage bed and marital relationship with its joys, sorrows and duties therefore largely defined ordinary people's lives. The source material clearly demonstrates the significance of marriage, especially for women. Court records, for example, typically defined women through men, either as the wives of their husbands or, in case of unmarried women, the daughters of their fathers. From a legal perspective, it was important to know under which man's guardianship and guidance a woman belonged. ${ }^{33}$ Legal and religious theories supported this view, and a similar categorisation was utilised by the clergy during the Middle Ages. It emphasised the moral value of women according to their marital status, but such a classification was also a value-laden political act. ${ }^{34}$

The chapter discusses family roles, parenthood and spousal relationships within the religious or devotional context. We do this by using case studies, especially the miracle story of the drowning and recovery of the five-year-old Johanna because of her parents' devotion to Thomas Cantilupe, and the story of Maria from Ulvila and her son-in-law, who accused each other of witchcraft as they fought for years over the control of a household, farmstead and family. The chapter uses original material from medieval and early modern canonisation processes and secular court records.

Chapter 2 asks how religion and gender were performed in the public sphere, and how those performances interacted. Not only was it ideologically inappropriate for women to have public power, it was also ideologically inappropriate for women to spend time in a public space. Religious teachings highlighted that in their own homes and under the control of their husbands, fathers, or other men of the family, women were safe from dangerous temptations. Space therefore held a moral dimension: virtuous women stayed at home. ${ }^{35}$ Dividing space into the masculine public space and the feminine private space was not a mere myth created by moralists; everyday tasks and duties tied women to their homes more closely than they did men. Nevertheless, it would be wrong to think that women were entirely absent from the streets and marketplaces of medieval or early modern towns and villages: just like men, women also had to take care of their chores and responsibilities, taking them outside the home sphere. In addition to leaving home for everyday jobs, women also attended church, went to the marketplace, appeared in court, visited relatives and embarked on pilgrimages.

The chapter discusses women's and men's public religious devotion and public speech, as well as the interplay between religion and work outside the home or in business. It uses various case studies, including a story of interactions between 
two widows - one living as a secluded noble lady and the other continuing her late husbands' shop - and case of Hans Smek, a knight of the Swedish king who was taught the earthly and heavenly hierarchies by Saint Birgitta and demons. The chapter investigates the ways religion, politics and the economy were interrelated: women could, for example, make political statements by their pilgrimages. Like Chapter 1, this chapter uses original material from medieval and early modern canonisation processes and secular court records.

Chapter 3 discusses how gender and religion were performed in the overtly religious sphere. What roles did women and men play in the church? In medieval and early modern ideologies, lay people in general belonged to the home and the economy, not to guiding the spiritual, despite the Reformation rhetoric of the priesthood of all believers. This was even more clear in the case of women. Both secular and ecclesiastical texts emphasise that women were committed to the home and that women's chores and duties took place in the private space. According to the canon law, for example, women were not allowed to teach, rule or testify in public. The latter restraint was laid down in Gratian's Decretum (circa 1140), although it presumably only applied to criminal cases. ${ }^{36}$ Nevertheless, it was never the whole picture even in ideological or didactic teaching: husbands, masters and housewives were always expected to provide spiritual guidance within their homes, and in practice most of the religious rituals that marked parish life both before and after the Reformations were performed by lay men and women.

How was devotion made to suit feminine or masculine roles or identities? We discuss the roles that Mary, Joseph and a range of saints were given in the medieval era and the Long Reformation Catholicism and Protestantisms. We also consider how these roles were used and imitated by lay devotees. This chapter returns to questions of power, motherhood and sexuality through narratives of heresy, demonic possession and witchcraft trials, including stories of women having copulated or made a pact with the Devil. The chapter uses original material from medieval exempla, canonisation processes and early modern secular court records.

Finally, the Conclusion returns to the questions posed in the introduction: how can this performance be conceptualised as a lived experience of gender and religion? Most importantly, how does such a conceptualisation change the historical investigation of either religion or gender? Our longue durée analysis will also deconstruct and challenge the traditional periodisation used in history research.

Churches as institutions, theology and philosophy are present in the background, but they are not the explicit focus of research in this book. We are interested in uncovering how the micro and macro levels were interconnected, how individual experiences and daily life contributed to and were shaped by dogma and societal factors. We use the conventional English names of rulers and other well-known individuals, while the original version found in the source material is used for persons otherwise unknown. All translations from the original sources were made by the authors.

This chapter is open access with funding from The Academy of Finland project Catholic Reformation in Lutheran Finland 1550-1700. 


\section{Notes}

1 Arnold, 'Histories and Historiographies', pp. 23-41; Katajala-Peltomaa and Toivo, 'Religion as Experience'.

2 Delumeau, 'Le prescript en la religion vécue', pp. 177-211.

3 Hall, Lived Religion in America; Orsi, The Madonna of 115th Street; McGuire, Lived Religion; Norris and Inglehart, Sacred and Secular; Ammerman, 'Lived Religion'; Bell, Ritual Theory, Ritual Practice; Moore, Touchdown Jesus.

4 Katajala-Peltomaa and Vuolanto, 'Religious Practices and Social Interaction', pp. 11-24; Marinković and Vedriš, Identity and Alterity in Hagiography.

5 See e.g. Dixon, Freist, and Greengrass, Living with Religious Diversity; Kaplan, Divided by Faith.

6 See e.g. Klapisch-Zuber, A History of the Women in the West.

7 Bennet, History Matters: Patriarchy and the Challenge of Feminism.

8 Scott, 'Secularism and Gender Equality'.

9 Ågren, Making a Living, Making a Difference.

10 See e.g. works on Islamic women's subjectivity by Mahmood, Politics of Piety; Gökariksel, 'Beyond the Officially Sacred' or Mack, 'Religion, Feminism and the Problem of Agency'.

11 Bynum, 'Holy Feast and Holy Fast'; Heal, The Cult of the Virgin Mary.

12 Bynum, Jesus as Mother; Newman, 'Crucified by the Virtues', pp. 182-209 for Cistercian monks depicting themselves with feminine images, and also their soul as Christ's bride.

13 Boydston, 'Gender as a Question'. See also Joan Scott arguing that gender is only useful as a question (not necessarily a category) in the 2008 American History Review.

14 Dalarun, 'The Clerical Gaze'.

15 Tinkle, Gender and Power.

16 Stephens, Demon Lovers; Katajala-Peltomaa, Demonic Possession and Lived Religion.

17 On Jerome's and Origen's comments, see Tinkle, Gender and Power in Medieval Exegesis, p. 23; Brown, The Body and Society, pp. 174, 188, and 376.

18 Bynum, Holy Feast and Holy Fast; Bynum, Fragmentation and Redemption, and Bynum, The Resurrection of the Body. See also her Christian Materiality, pp. 31-33 for a caveat against taking the body as a synonym for a person or individual. See Biernoff, Sight and Embodiment in the Middle Ages, pp. 23-37 for a critique of the idea that patristic and medieval authors had a dualistic model of the body as a psychosomatic unity and potential site for redemption, and of the flesh as the sinful body encompassing carnal desires. See also de Groot and Morgan, 'Introduction: Beyond the "Religious Turn"?', pp. 1-29. For fruitful theorising, see also Ahmed, 'Some Preliminary Remarks' and Mahmood, Politics of Piety.

19 Kelly, Performing Virginity, pp. 3-7; see also Evans, Salih, and Bernau, Medieval Virginities; Arnold, 'The Labour of Continence', pp. 102-118; Karras, 'Thomas Aquinas's Chastity Belt', pp. 52-67.

20 Karras, 'Thomas Aquinas's Chastity Belt' and Karras, Sexuality in Medieval Europe, pp. 56-57.

21 Bynum, Jesus as Mother; McNamer, Affective Meditation; Lindgren, Sensual Encounters, and Bryan, Looking Inward.

22 Tinkle, Gender and Power, p. 79. See also Corbari, Vernacular Theology, pp. 164-165.

23 Bouquet and Nagy, Sensible Moyen Âge.

24 Backman, ‘Äärellisyyden kohtaaminen', pp. 26-27.

25 Toikkanen, 'Välineen käsite'; Toikkanen and Virtanen, 'Kokemuksen käsitteen ja käytön jäljillä', pp. 7-24.

26 Scott, 'The Evidence of Experience'.

27 Jones, 'Un autre histoire social'; Carr, Experience and History; Lepedit, Forms de l'experience.

28 Boddice and Smith, Emotion, Sense, Experience.

29 Scott, 'The Evidence of Experience'; Jay, Songs of Experience; Lepedit, Les forms de l'experience; on the anthropology of experience, all articles in Turner and Bruner, The Anthropology of Experience. 
30 Rosenwein, 'Worrying', p. 842. Rosenwein's concepts have been criticised for their imprecision, but we use the imprecision here with purpose: the experiencing community is only an example of the spheres where experience is a magnet to the compass guiding the historian rather than a thing on its own. see e.g. Plamper, 'The History of Emotions,' pp. 237-265.

31 Tyacke, England's Long Reformation and Wallace, The Long European Reformation. See also e.g. Spurr, The Post Reformation. On conciliarist ideas in the 14th century, see Oakley, The Mortage of the Past, pp. 209-219. On later developments, see Oakley, The Watershed of Modern Politics. Also Mullet, The Catholic Reformation, pp. 1-28; Bolton, The Medieval Reformation. Arnold, Belief and Unbelief in Medieval Europe. On religious dissent in the Reformation era, see Martin, Venice's Hidden Enemies.

32 E.g. Haigh, English Reformations or Ryrie, The European Reformations.

33 Farmer, Surviving Poverty, p. 40.

34 Partly because of this kind of classification of women, the categorisation of 'single women' was particularly perplexing for the elite. Cordelia, Medieval Single Women.

35 For moral teachings about space and gender, see e.g. Casagrande, 'The Protected Woman', p. 85, and Hanawalt, 'Of Good and Ill Repute', pp. 20-26.

36 For women as witnesses, see e.g. Wetzstein, Heilige vor Gericht, pp. 65-66.

\section{Bibliography}

Ågren, Maria (ed.). Making a Living, Making a Difference: Gender and Work in Early Modern European Society. Oxford: Oxford university Press, 2016.

Ahmed, Sara. 'Some Preliminary Remarks on the Founding Gestures of the New Materialism'. European Journal of Women's Studies 15 (2008): 23-39.

Ammerman, Nancy T. 'Lived Religion'. In Emerging Trends in Social and Behavioral Sciences, edited by Robert A. Scott, Stephen M. Kosslyn, and Marlis Buchmann. Hoboken: John Wiley \& Sons, 2015. https://doi.org/10.1002/9781118900772.etrds0207 (no pagination).

Arnold, John H. 'The Labour of Continence: Masculinity and Clerical Virginity'. In Medieval Virginities, edited by Anke Bernau, Ruth Evans, and Sarah Salih, 102-118. Toronto and Buffalo: University of Toronto Press, 2003.

Arnold, John H. Belief and Unbelief in Medieval Europe. London: Hodder Arnold, 2005.

Arnold, John H. 'Histories and Historiographies of Medieval Christianity'. In The Oxford Handbook of Medieval Christianity, edited by John H. Arnold, 23-41. Oxford: Oxford University Press, 2014.

Backman, Jussi. 'Äärellisyyden kohtaaminen: kokemuksen filosofista käsitehistoriaa'. In Kokemuksen tutkimus VI, Kokemuksen käsite ja käyttö, edited by Jarkko Toikkanen and Ira A. Virtanen, 25-40. Rovaniemi: Lapland University Press, 2018.

Beattie, Cordelia. Medieval Single Women: The Politics of Social Classification in Late Medieval England. Oxford: Oxford University Press, 2007.

Bell, Catherine. Ritual Theory, Ritual Practice. Oxford: Oxford University Press, 1992.

Bennet, Judith. History Matters: Patriarchy and the Challenge of Feminism. Philadelphia: University of Pennsylvania Press, 2006.

Biernoff, Suzannah. Sight and Embodiment in the Middle Ages. Houndmills: Palgrave McMillan, 2002.

Boddice, Rob, and Mark M. Smith. Emotion, Sense, Experience. Cambridge: Cambridge University Press, forthcoming.

Bolton, Brenda. The Medieval Reformation. London: Edward Arnold, 1983.

Bouquet, Damien, and Piroska Nagy. Sensible Moyen Âge: Une histoire des émotions dans l'Occident médiéval. Paris: Seuil, 2015. 
Boydston, Jean. 'Gender as a Question of Historical Analysis'. Gender and History 20, no. 3 (2008): 558-583.

Brown, Peter. The Body and Society: Men, Women, and Sexual Renunciation in Early Christianity. New York: Columbia University Press, 1988.

Brunder, Edward. 'Experience and Its Expressions'. In The Anthropology of Experience, edited by Victor Turner and Edward Bruner, 3-30. Urbana and Chicago: University of Illinois Press, 1986.

Bryan, Jennifer. Looking Inward: Devotional Reading and the Private Self in Late Medieval England. Philadelphia: University of Pennsylvania Press, 2008.

Bynum, Caroline Walker. Jesus as Mother: Studies in the Spirituality of the High Middle Ages. Berkeley: University of California Press, 1982.

Bynum, Caroline Walker. Holy Feast and Holy Fast: The Religious Significance of Food to Medieval Women. Berkeley: University of California Press, 1987.

Bynum, Caroline Walker. Fragmentation and Redemption: Essays on Gender and the Human Body in Medieval Religion. New York: Zone Books, 1991.

Bynum, Caroline Walker. The Resurrection of the Body in Western Christianity, 200-1336. New York: Columbia University Press, 1995.

Bynum, Caroline Walker. Christian Materiality: An Essay on Religion in the Late Medieval West. New York: Zone Books, 2011.

Carr, David. Experience and History. Oxford: Oxford University Press, 2014.

Casagrande, Carla. 'Protected Woman'. In A History of Women, Vol. II: Silences of the Middle Ages, edited by Christiane Klapisch-Zuber, 70-104. Cambridge, MA: The Belknap Press of Harvard University Press, 1994.

Corbari, Eliana. Vernacular Theology: Dominican Sermons and Audience in Late Medieval Italy. Berlin and Boston: Walter de Gruyter, 2013.

Dalarun, Jacques. 'The Clerical Gaze'. In A History of Women, Vol. II: Silences of the Middle Ages, edited by Christiane Klapisch-Zuber, 15-42. Cambridge, MA: The Belknap Press of Harvard University Press, 1994 (1990).

de Groot, Joanna, and Sue Morgan. 'Introduction: Beyond the "Religious Turn"? Past, Present and Future Perspectives in Gender History'. In Sex, Gender and the Sacred: Reconfiguring Religion in Gender History, edited by Joanna de Groot and Sue Morgan, 1-29. Oxford: John Wiley \& Sons, 2014.

Delumeau, Jean. 'Le prescript en la religion vécue. Leçon inaugurale au Collège de France 13 fèvrier 1975'. In Le Christianisme, va-t-il mourir? edited by Jean Delumeau, 177-211. Paris: Hachette, 1977.

Dixon, C. Scott, Dagmar Freist, and Mark Greengrass (eds). Living with Religious Diversity in Early-Modern Europe. Aldershot: Ashgate, 2009.

Evans, Ruth, Sarah Salih, and Anke Bernau (eds). Medieval Virginities. Toronto: University of Toronto Press, 2003.

Farmer, Sharon A. Surviving Poverty in Medieval Paris: Gender, Ideology, and the Daily Lives of the Poor. Ithaca: Cornell University Press, 2002.

Gökarıksel, Banu. 'Beyond the Officially Sacred: Religion, Secularism, and the Body in the Production of Subjectivity'. Social \& Cultural Geography 10, no. 6 (2009): 657-674.

Haigh, Christopher. English Reformations: Religion, Politics and Society Under the Tudors. Oxford: Clarendon Press, 1993

Hall, David D. (ed.). Lived Religion in America: Toward a History of Practice. Princeton: Princeton University Press, 1997.

Hanawalt, Barbara. 'Of Good and Ill Repute': Gender and Social Control in Medieval England. New York and Oxford: Oxford University Press, 1998. 
Heal, Bridget. The Cult of the Virgin Mary in Early Modern Germany: Protestant and Catholic Piety 1500-1648. Cambridge: Cambridge University Press, 2007.

Jay, Martin. Songs of Experience. Berkeley: California University Press, 2006.

Jones, Gareth Stedman. 'Une Autre Histoire Social?'. Annales. Histoire, Sciences Sociales 53, no. 2 (1998): 383-394.

Kaplan, Benjamin J. Divided by Faith: Religious Conflict and the Practice of Toleration in Early Modern Europe. Cambridge, MA: The Belknap Press of Harvard University Press, 2007.

Karras, Ruth Mazo. Sexuality in Medieval Europe: Doing unto Others. New York: Routledge, 2005.

Karras, Ruth Mazo. 'Thomas Aquinas's Chastity Belt: Clerical Masculinity in Medieval Europe'. In Gender and Christianity in Medieval Europe: New Perspectives, edited by Lisa M. Bitel and Felice Lifshitz, 52-67. Philadelphia: University of Pennsylvania Press, 2008.

Katajala-Peltomaa, Sari. Demonic Possession and Lived Religion in Later Medieval Europe. Oxford: Oxford University Press, 2020.

Katajala-Peltomaa, Sari, and Raisa Maria Toivo. 'Religion as Experience'. In Lived Religion and Long Reformation in Northern Europe c. 1300-1700, edited by Sari KatajalaPeltomaa and Raisa Maria Toivo, 1-18. Leiden: Brill, 2017.

Katajala-Peltomaa, Sari, and Ville Vuolanto. 'Religious Practices and Social Interaction in the Ancient and Medieval World'. In Religious Participation in Ancient and Medieval Societies: Rituals, Interaction and Identity, edited by Sari Katajala-Peltomaa and Ville Vuolanto, 11-24. Acta Instituti Romani Finlandiae, vol. 41. Rome: Institutum Romanum Finlandiae, 2013.

Kelly, Kathleen Coyne. Performing Virginity and Testing Chastity in the Middle Ages. London: Routledge, 2000.

Klapisch-Zuber, Christiane. 'Including Women'. In A History of Women in the West, Vol. II: Silences of the Middle Ages, edited by Christiane Klapisch-Zuber, 70-104. Cambridge, MA: The Belknap Press of Harvard University Press, 1994 (1990).

Kukkola, Jani. 'Kokemuksen tutkimuksen metatiede: kokemuksen käsitteen käytön ja kokemuksen ehtojen tutkimus'. In Kokemuksen tutkimus VI, Kokemuksen käsite ja käyttö, edited by Jarkko Toikkanen and Ira A. Virtanen, 41-63. Rovaniemi: Lapland University Press, 2018.

Lindgren, Erika Lauren. Sensual Encounters: Monastic Women and Spirituality in Medieval Germany. New York: Columbia University Press, 2009.

Mack, Phyllis. 'Religion, Feminism, and the Problem of Agency: Reflections on Eighteenth-Century Quakerism'. In Women, Gender and Enlightenment, edited by Sarah Knott and Barbara Taylor, 149-177. Basingstoke: Palgrave Macmillan, 2005.

Mahmood, Saba. Politics of Piety: The Islamic Revival and the Feminist Subject. Princeton, NJ: Princeton University Press, 2005.

Marinković, Ana and Trpimir Vedriš (eds). Identity and Alterity in Hagiography and the Cult of Saints. Biblioteca Hagiotheca 1. Zagreb: Hagiotheca, 2010.

Martin, John. Venice's Hidden Enemies: Italian Heretics in a Renaissance City. Berkeley: University of California Press, 1993.

McGuire, Meredith B. Lived Religion: Faith and Practice in Everyday Life. Oxford: Oxford University Press, 2008.

McNamer, Sarah. Affective Meditation and the Invention of Medieval Compassion. Philadelphia: University of Pennsylvania Press, 2010.

Moore, R. L. Touchdown Jesus: The Mixing of Sacred and Secular in American History. Louisville: Westminster John Knox, 2003. 
Mullet, Michael. The Catholic Reformation. London: Routledge, 1999.

Newman, Martha. 'Crucified by the Virtues: Monks, Lay Brothers, and Women in Thirteenth-Century Cistercian Saints' Lives'. In Gender and Difference in the Middle Ages, edited by Sharon Farmer and Carol Braun Pasternack, 182-209. Minneapolis: University of Minnesota Press, 2003.

Norris, Pippa and Ronald Inglehart. Sacred and Secular: Religion and Politics Worldwide. Cambridge: Cambridge University Press, 2011.

Oakley, Francis. The Mortage of the Past: Reshaping the Ancient Political Inheritance (10501300). New Haven and London: Yale University Press, 2012.

Oakley, Francis. The Watershed of Modern Politics: Law, Virtue, Kingship, and Consent (1300-1650). New Haven and London: Yale University Press, 2015.

Orsi, Robert. The Madonna of 115th Street. Faith and Community in Italian Harlem, 18801950. New Haven: Yale University Press, 1985.

Oxford English Dictionary. www.oed.com/

Plamper, Jan. 'The History of Emotions: An Interview with William Reddy, Barbara Rosenwein, and Peter Stearns'. History and Theory 49, no. 2 (2010): 237-265.

Rosenwein, Barbara H. 'Worrying About Emotions in History'. The American Historical Review 107, no. 3 (June 2002): 821-845. https://doi.org/10.1086/ahr/107.3.821

Ryrie, Alec (ed.). The European Reformations. London: Palgrave Macmillan, 2006.

Scott, Joan. 'The Evidence of Experience'. Critical Inquiry 17, no. 4 (1991): 773-797.

Scott, Joan. 'Unanswered Questions', Contribution to AHR Forum, Revisiting 'Gender: A Useful Category of Historical Analysis'. American Historical Review 113, no. 5 (December 2008): 1422-1430.

Scott, Joan. 'Secularism and Gender Equality'. In Religion, the Secular and the Politics of Sexual Difference, edited by Linell E. Cady and Tracy Fessenden. New York: Columbia University Press, 2013.

Spurr, John. The Post Reformation, 1603-1714. Harlow: Pearson, 2006.

Stephens, Walter. Demon Lovers: Witchcraft, Sex, and the Crisis of Belief. Chicago: University of Chicago Press, 2002.

Tinkle, Theresa. Gender and Power in Medieval Exegesis. New York: Palgrave McMillan, 2010.

Toikkanen, Jarkko. 'Välineen käsite ja välinemääräisyys 2010-luvulla'. Media \& viestintä 40, no. 3-4 (2017): 69-76.

Toikkanen, Jarkko, and Ira A. Virtanen. 'Kokemuksen käsitteen ja käytön jäljillä'. In Kokemuksen tutkimus VI, Kokemuksen käsite ja käyttö, edited by Jarkko Toikkanen and Ira A. Virtanen, 7-24. Rovaniemi: Lapland University Press, 2018.

Turner, Victor, and Edward Brunder (eds). The Anthropology of Experience. Urbana and Chicago: University of Illinois Press, 1986, 3-30.

Wallace, Peter G. The Long European Reformation. Basingstoke: Palgrave, 2012.

Wetzstein, Thomas. Heilige vor Gericht: Das Kanonisationsverfahren im europäischen Spätmittelalter. Cologne: Böhlau, 2004.

William, Tyacke (ed.). England's Long Reformation. London: Taylor and Francis, 2004. 


\section{LIVED RELIGION AND LIVED GENDER IN FAMILY LIFE}

Family life, domesticity and the household were essential constituents of the medieval and early modern world. Since the private and the public were not yet distinct and separate spheres, the home was the site for intimate relationships and the provision of daily necessities, but also for political and economic negotiations and daily labour. The household provided the physical structure for daily life, and the family could include members other than the nuclear family or closest kin. Nevertheless, the idea of domesticity, reflecting privacy and comfort, was emerging during this time. ${ }^{1}$ For medieval and early modern people, the home was a physical, social and mental space incorporating care and affection, but also conflict and competition. Within the home, children were raised and socialised, gendered expectations were negotiated and fulfilled, and religion was practised. Obviously, the physical frames for this space, the material means and the culture varied greatly according to the geographic area, urban or rural space, age, wealth and social status of its members.

Domestic and familial ideologies form the background for the discussion, but as our intention in this volume is to illuminate the lived experiences of medieval and early modern people, family relations are approached from the perspective of two narrations constructed from court cases. The first casts light on a peasant family near the English-Welsh border at the turn of the 14th century, and the latter describes the occurrences of a peasant family in western Finland at the end of the 17th century. Both cases include young women, their parents and potential spouses as protagonists. Intra-family negotiations, both between parents and children as well as between spouses or siblings, are discussed as we follow the fate of Johanna and Dordi.

\section{Saint Thomas' virgin in the tavern}

The life-changing event for the Schirreve family took place on a Sunday afternoon in April, just before Saint George's Day (celebrated on 23 April), as the witnesses testifying before papal commissaries reported. They were not, however, 
unanimous about the year; some witnesses reported the events that had taken place fifteen years earlier while others claimed that twenty years had already passed. The case and its details were recounted to papal commissaries in 1307 , when they interrogated people about the sanctity of Thomas Cantilupe and the miracles he had performed. Ten witnesses testified to the Schirreve family miracle. $^{2}$

It all happened around the year 1290, when Adam Schirreve and his wife Cecilia left their home to visit the tavern in Walterus de la Wyle's house in the nearby village of Marden. The Sunday in question was not a public holiday, but a time for recreation nonetheless: many locals had gathered in the tavern to enjoy themselves. Adam and Cecilia had prepared for an evening out by leaving their children at home, but when they were nearing the tavern, they noticed Johanna, their five-year-old daughter, had followed them.

Adam and Cecilia decided to let Johanna stay at the tavern because other children were also present. Johanna soon started playing in the de la Wyle garden with her godmother's son, Johannes, who was only a little younger than her. The tavern's atmosphere was rowdy and buzzing with conversation; later estimates of the number of people present ranged from sixty to one hundred. Both men and women were present, the conversation was lively, and people started dancing, forming a long line that snaked around the tavern and garden.

Moral writings considered visits to the tavern and dancing in particular as highly condemnable activities. Drink and the revolving movement of dance could confuse even the most sensible men. The physical closeness of dancing made the act lewd, and dancing brought colour to people's cheeks, making even the most modest-looking women look charming and attractive. Moral ruin was thus inevitable. The movement itself was lewd - it was an insult to God and pleasing to the Devil, as the moralists of the era put it. ${ }^{3}$

As spaces, taverns were ambiguous. On the one hand, taverns were usually private homes, like in this case - people had gathered in Walterus de la Wyle's house. On the other hand, taverns were public spaces in the sense that everyone was welcome. Regular visits could, however, gain women in particular a questionable reputation. ${ }^{4}$ The peasants making merry at the de la Wyle tavern did not agree with the notion that tavern visits marred people's reputation: the witness statements showed no sign of condemnation towards any of the attendees, including the women. When asked by the commissaries, all the witnesses described each other as reputable people and good Christians. The attendance of the women - at least with their spouses - at the local tavern gathering therefore presumably did not tarnish their reputation or violate the unwritten moral rules of the peasant community.

General merriment was probably why Cecilia and Johanna Wase, little Johanna's godmother, failed to understand what little Johannes was trying to say. Thomas Schonk, the father of Johannes, however, did understand his son, and he quickly dragged the boy home: while the adults had been celebrating in the tavern, there had been an accident in the garden. A group of dancers later happened 
on the spot and noticed something terrifying: in the middle of the garden there was a deep pond, and in the pond there was a drowned child. How terrible - and how troublesome. This meant that the finders had to call the coroners and later give testimony in court. That was the end of merriment, but worse still, attending court took time and effort, and the people concerned might even be fined for some offence. ${ }^{5}$

The witness statements are not entirely clear on whether the dancers included any women, but it would seem that only men took part in negotiating and planning the actions after the accident. This was understandable because among English peasants, it was mainly the men's right and duty to appear in court. Men pleaded women's cases in court for them, especially in the case of married women, and men were thus more familiar with not only the legal ramifications but also the troubles and dangers of attending court. ${ }^{6}$

Johannes de Pirebok, one of the dancers, was the tavern owner's relative, and he wanted to tell the owner what had happened. The tavern owner was responsible for running the business and ensuring the patrons' welfare, and he also answered for them in court. Others, however, came up with what they thought a better plan: they wanted to dump the body in a nearby river at night to make someone else the finder and pass the responsibilities and legal consequences on to that person. Although this plan may seem cold-blooded and ruthless, it does not necessarily indicate social insignificance of children or demonstrate a lack of emotional commitment towards them. The men assumed the victim was a local beggar's daughter: they thought that the beggar woman had drowned her daughter because of her poverty, misery and hopelessness. So, this was no unforeseen accident, and there was no longer anything they could do about it.

The men did not abandon their idea even after Thomas Shonck learned the victim's true identity from his son: Johannes had pushed Johanna into the pond in the heat of play. Because the pond was deep, with steep edges where only tender grass grew, Johanna could not get out on her own, and so she drowned. Instead of telling Johanna's parents about the accident, Thomas quickly took his son home, possibly believing he was protecting the boy by doing so. However, Johannes ran away from his nurse and at sunset returned to the tavern. He told Cecilia and his mother again what had happened. This time the women understood Johannes and went to the pond in the garden.

Johanna Wase could not swim, but she climbed down into the pond and managed to drag the drowned child out of water. Cecilia looked down on the body Johanna had pulled up. The victim had muddy clothes, a contorted face, and a swollen tongue that stuck out from between her teeth. Was this creature supposed to be her daughter? But then Cecilia noticed the girl's shoes: they had red laces. They were the shoes she had bought her daughter the previous day. Cecilia realised that the victim was indeed her Johanna and burst into tears.

Philippe Ariès, a pioneer in the research of the history of childhood, claimed that in the Middle Ages, childhood was not acknowledged or recognised as a separate period of development in a person's life. He also argued that parents 
and children did not share a strong emotional bond. Ariès' book was originally published in 1960; it is nowadays outdated, and his claims were discredited soon after its publication, but they persist stubbornly, especially in more popular ideas of medieval family life. ${ }^{7}$ His work has had a tremendous affect, and even today scholars feel obliged to dispute and discuss his arguments.

Events at the de la Wyle garden tell another tale of emotional bonds within the family. Cecilia was not the only one crying - everyone mourned - but her grief was so deep that it worried others. Cecilia was with child and near her time, and others worried her distress would cause her to miscarry. When Cecilia refused to let go of her daughter, instead holding the limp, wet, and cold body in her arms, they decided to move Johanna first to the tavern and from there to her own home. When Cecilia still refused to let go of her little daughter, the mother and daughter were tucked up in a bed by a fire.

Expressions of grief and distress are common at the scene of an accident, and parents sometimes displayed extreme emotional reactions. Johannes Piscatoris, for example, was reported to have fallen to the ground unconscious when he found his son Nicholas drowned. One mother, a certain Diomisia, is said to have gone nearly insane after she realised her two-year-old son Rogerus had fallen into a moat in the middle of the night and died. Tears, wailing and the rending of hair are common expressions of emotion at accident scenes. ${ }^{8}$

Obviously, these signs may have been genuine expressions of emotional stress due to the sudden accident remembered vividly and described in detail fifteen years after the accident. At the same time they were, however, part of the proper ritual and narration of a miracle. A desperate situation beyond human help was the prerequisite for a recovery to be considered divine grace. For the commissioners carrying out the official interrogation, these emotions - the desperation, fear and sorrow - were sign and served as a validation of the case as a miracle, as they were the expected responses at this stage of the miracle process, i.e. before divine intervention. From a theological perspective, these 'movements of the soul', if we are to follow medieval understanding of what we today call emotions, were essential constituents of religion leading to either salvation or damnation. ${ }^{9}$ At the same time, emotions functioned in the social context producing and manifesting change: tears and wailing were symbolic communication, both towards the surrounding community manifesting parental loss, but also towards the heavenly intercessor, thus manifesting subordination and the need for help. Pleading for a saint's intercession was a coping strategy in a moment of distress, and it encapsulates the way religion-as-lived intermingled with daily options and responsibilities without leaving spirituality aside.

From a modern perspective, medieval parents often portrayed a confusing mix of strong emotional bonds and trust in their children's ability to make it on their own. Adam and Cecilia, for example, were apparently not concerned about losing sight of their five-year-old daughter for hours on end in a strange place. Diomisia, the mother who went beside herself, first refused to leave an overnight wake to go look for her child, even though the boy's father reported that the two-year-old had gone missing from his bed. 
In Johanna Schirreve's case, the actions of the people present were not limited to mourning. When the victim had been recovered from the pond, they tried to restore the girl to life. When the physical attempts were unsuccessful, they decided on Adam's initiative to plead to a local saint - the former local bishop, Thomas Cantilupe - who they believed could perform miracles. In addition to the parents, many others at the tavern took part in the pleading rituals. They were very persistent in their pleas and called for Thomas' help both by the pond and at the tavern. Later, the helpers followed the Schirreve family home and stayed all night to pray for the girl.

The first signs of life came at sunrise, when Johanna replied to her mother's question. According to Cecilia's statement, she was lying in bed and whispering into her daughter's ear, asking what she had been doing in the water, when Johanna had replied to her mother that Johannes had pushed her. Cecilia told the others this, and people praised God and Thomas Cantilupe. It was a great joy to see Johanna, presumed dead, restored to life, and many community members also participated in offering ritual thanks. A mass was celebrated to give thanks for the miracle at the parish church, and later a large group made a pilgrimage to Thomas Cantilupe's grave in Hereford to express their gratitude.

The Schirreve family's gratitude was long-lived. At the time of the interrogation, more than fifteen years after the incident, the parents reported that the whole family still made annual pilgrimages to Thomas Cantilupe's grave usually barefoot. In the miracles witnessed by English peasants and recounted to commissaries, the whole family typically took part in both pleading for help and giving thanks. Ensuring children's welfare, even if it required divine intervention, seems to have been the duty of both the father and the mother. In light of this story, canonisation records and other legal sources in general, it seems that the caregiving was not - especially in rural areas north of the Alps - solely feminine, and fathers also actively looked after their children. ${ }^{10}$

This may be an illustration of agrarian society's gender roles in general: running a farm required collaboration. Although work and duties were often assigned based on gender, they were guided by a common interest. This is perhaps why in an agrarian society, childcare was also considered a shared duty more often than in other cultural spheres. For example, the miracles recounted in Italy's urban areas portray the caregiving role differently: women and mothers in particular looked after children and the ill, and the carer's role was a feminine duty. Looking after children and the ill was not just a selfless, or indeed, taxing duty - caregiving also awarded the nurturer considerable power. The carer could, for example, decide which cures to use. University-trained physicians and lay healers were available in the urban areas of Italy in the Middle Ages. In addition to asking for the help and advice of seasoned healers, carers also regularly turned to spells and/or saints. Asking for a saint's help created a spiritual bond, because the petitioner had to offer the divine intercessor a counter-gift. It was a grave sin to act ungratefully or break this promise, which was also a financial commitment. 
In medieval and early modern social theory and philosophy, parenthood was gendered, authority in parenting even more so. Both parents were supposed to love and guide their children, but the mother's role was expected to be greater with smaller children, and the father's role was expected to grow as the children grew into young adulthood. Expectations of what parental care included were also divided. Whereas mothers were expected to care, feed and comfort, fathers could also be occasionally required to rock cradles and soothe babies. Physical discipline was more often understood as the father's duty of love: mothers were thought to be too weak to discipline their children in an orderly and rational fashion. In particular, the education of boys older than seven was considered the father's duty. ${ }^{11}$

Maternal care could also challenge masculine authority, as clearly happened in the case of Boniacobus and Angelucia's two-year-old son, Manfredus, who fell into boiling water and hurt himself badly. Boniacobus was a doctor and tended to his son, but to no avail: the boy's right arm was still paralysed a year after the incident. Angelucia then decided to take charge of her son's care and pleaded to Saint Nicholas of Tolentino for help. Manfredus was cured within a month. Only Angelucia's version of the events has survived, but she was certain that she had had a decisive role in the events: she claimed that Manfredus was cured thanks to her plea and Saint Nicholas' help, not by Boniacobus' treatment. ${ }^{12}$

As the Schirreve family case shows, counter-gifts offered to saints could be socially very demanding: the family was committed to revering Thomas Cantilupe even fifteen years after the miracle. Johanna's incident was a life-changing experience; it had far-reaching effects for the whole family. The miracle identified Johanna if not for the rest of her life, then at least up to the point when she and her parents gave statements to the papal commissaries in Hereford in 1307. In his witness statement, Johanna's father reported that even at the time of the interrogation, high-born guests from faraway places were still coming to see Johanna because of the miracle, proving that the memory of the miracle still lived on. After the incident, Johanna was commonly known as Saint Thomas' virgin. Children were often named after the family's patron saint or the saint celebrated on the child's birthday. Although naming practices varied greatly from one cultural sphere to another, it was very common to name miraculously rescued children after their patron saint, and Johanna's case was no different. What was different, however, was that this kind of identification seems to have been uttermost meaningful: Johanna seemed to take her reputation as the virgin of Saint Thomas very seriously. She wanted to remain a virgin and refused to marry, despite her parents' wishes, because of her miraculous cure.

Voluntary celibacy was not unheard of among medieval peasants, but it was rare. At the time of the interrogation, Johanna was probably just over twenty years old. This was presumably the typical age for English peasants - and central and northern European peasants in general - to marry, so Johanna had not yet exceeded the average marrying age. The story's ending remains in the dark: witness statements do not reveal whether Johanna eventually acquiesced to her 
parents' wishes and agreed to marry, or whether she remained the virgin of Saint Thomas for the rest of her life.

Johanna's miraculous cure is an interesting illustration of the social relations and family interactions of English peasants. The story's beginning, the events that took place before the tragic accident and the drowning itself, portray a relatively equal relationship between the husband and wife, the father and mother. Both spent time with their friends and neighbours at the tavern, and both were extremely shocked to discover their daughter's accident, although the mother's emotions are reported to have been somewhat stronger. Childcare seems to have been the duty of both parents, as is emphasised by the fact that both pleaded for the saint's intercession and repeatedly offered their thanks, along with their shared concern and responsibility for their daughter's future in later years.

In her witness statement, Johanna recounts that both her father and mother tried to talk her into taking a husband. Marriage was therefore not solely the father's preference, contrary to what clergymen's writings often suggest. In these writings, the father's responsibility is to offer his household members guidance and instruction and to choose spouses for his children. In the case of the Schirreves, Cecilia also seems to have participated in family negotiations. Witness statements clearly suggest that there may have been an internal conflict within the family, but it appears that Adam and Cecilia did not force Johanna to marry. Her marriage was indeed something the family negotiated and discussed, and perhaps even argued about, but Adam does not appear to have wielded absolute authority on the matter.

Medieval modes of record-keeping strongly influence our ability to gain information about unmarried people, especially women. Women were associated with the reproductive sphere by clerics and secular authorities, meaning they were often identified by the men of their families in documents: they are noted as the daughters of their fathers or the wives (or widows) of their husbands. Unmarried women ruptured the ideal gender order of legal and religious theories, and their marital status is often ignored in documentation. ${ }^{13}$ Plenty of information about unmarried women and men who worked all their lives is available from later times. ${ }^{14}$ Often in the Middle Ages, the only alternative to marriage presented was taking the veil. This was financially possible for upperclass women only, because convents typically required a considerable dowry of their initiates. Hereford and its surrounding areas hosted several monasteries and convents. Perhaps Johanna wanted to settle down in a convent and live not only as the virgin of Saint Thomas but also as a bride of Christ. We cannot be sure, because her witness statement does not explicitly mention a desire to become a nun.

A daughter's marriage was very important in determining the family's future. Although peasant marriages did not form political alliances or significant trade relations, the family nevertheless had a considerable say and influence in the choice of spouse. Families wanted to ensure the viability of the upcoming union, the suitability of the couple and the security of their financial standing so that 
the couple could become independent. Choosing a religious career was likewise something that interested the whole family, because this career choice affected everyone in the family. When family members adopted an ecclesiastical career, they became responsible for the family's relations with the religious sphere: they were expected to pray for their family and elevate their family's social standing. This strategy was not unknown to families of modest background either. ${ }^{15}$

The Schirreve family was also familiar with a family member assuming a life in the church, but the child chosen to pursue a religious career was Johanna's brother, also called Johannes. Witness statements do not reveal whether this choice had been made before Johanna's accident or perhaps as a result of it. In any case, the decision was not simple: Johannes could not be ordained and promoted to the clergy without titulus, a sufficient inheritance or income. Adam Schirreve enjoyed titulus, but he did not want to give it up for his son. Adam himself does not mention this, but it is possible that his reasons related to the financial impossibility of giving up an income that supported the family. Cecilia mentions her son's career but does not explain Adam's reasons; she only states that Adam did not want to renounce his inheritance for his son. Nevertheless, Cecilia did not remain idle. She again pleaded to Saint Thomas, promised her son to him and took Johannes on a pilgrimage to Saint Thomas' grave in Hereford cathedral. This solved their problem: a nearby knight soon offered Cecilia's son an income at his own chapel, where Johannes was later promoted. Cecilia was convinced that this, too, was Saint Thomas' doing.

The commissaries conducting the judicial hearing may have disagreed, because this miracle is not included in later summaries of miracles in the canonisation process. The role of divine help in the events remains unclear, but it is clear that both Johanna and Cecilia seemed to have openly challenged Adam's authority. This detailed story of the everyday life and family interaction of an English peasant family does not exactly confirm the clergy's teachings on the proper place of a man and woman, the husband's authority, or the duty of the wife and children to obey the head of the family.

As the case of Johanna shows, religion offered norms and regulations but at the same created a performative space. Invoking a saint's aid for their drowned daughter and manifesting their gratitude after the recovery offered Adam and Cecilia the opportunity to show their parental care and piety. The repeated pilgrimages to the shrine were also a way to construct a collective identity for the whole family and refresh the memories of their experience, positioning themselves as the beneficiaries of a saint. Clear enough, (near-)drowning experience could have been a life-turning incident for anyone, not least because of the potential physiological consequences. Rather than a singular occurrence, the family took measures to make this unfortunate accident a culturally significant and approved religious experience for the whole family. This was further underlined by the paths taken, namely the repeated pilgrimages as a ritual of collective memory, Johannes' ordination and Johanna's sense of self as a virgin of Saint Thomas. By their ritual practices and repeated narrations of the event, they were 
not only telling a story of a drowning but also of their position and identity. The intended audience was the Divine and themselves, but also the surrounding community inspecting them. The performance of religion, gender and family roles were entangled. Religion as a lived practice and especially the construction of their experience as miraculous guided their life course.

Domesticity could mean the comfort of one's own home, the affective relationships between family members, and care and commitment. At the same time, it meant responsibilities, hierarchy, and the renunciation of personal preferences for the general benefit of the family. This meant different things for different family members. Men were not necessarily the heads of the household, as will be shown shortly; furthermore, taking care of one's dependents did not necessarily mean uncontested authority or just drawing the 'bigger picture' of the future. The connection between femininity and nurturing was and is strong in western imaginary. Maternal caregiving was considered natural in medieval clerical rhetoric, and it is often taken for granted even today. In clerical rhetoric, day-to-day nurturing was traditionally considered to be the mother's task. Quite often, the parental responsibilities were concretised in daily caregiving, which comprised of many aspects - also for men. It included taking care of daily needs, socialising the child into norms and customs, and moral upbringing. Religionas-lived was inherent in all these elements.

Concrete nurturing was part of paternal responsibilities, and this was the case especially among the lower strata. The survival of a child, not to mention many children, required collaboration and commitment from both the mother and father, since both parents had to simultaneously work long days. This does not exclude a gendered division of labour in agrarian production. The categorisation of work was not fixed, but women in general were more involved in dairy work and tasks involving small livestock, while men worked in arable farming and forestry. ${ }^{16}$ The mixture of labour division and joint responsibility for nurturing is reflected in a harsh way in the findings of Barbara Hanawalt. While studying late medieval English coroners' rolls, she found that fathers were nearly as often as mothers the first to find their son after an accident. To be the finder of the victim of an accident obviously implies an interest in the well-being of a child. Mothers and fathers seem to have been equally active in taking care of their sons, while mothers were clearly more often the first finder of their daughters, which may imply their heightened interest compared to fathers. The reason for the fathers' activity in the case of sons may have been their greater commitment to their sons compared to their daughters, but fathers and growing boys also shared many of the daily routines and spaces - as did mothers with their daughters - which facilitated the finding and made it more plausible. ${ }^{17}$

On the whole, we know of actual medieval caregiving practices only through these kinds of occasion - when something had gone wrong and the events were reported to the officials. In addition to secular court records, canonisation processes offer a similar window on the daily performance of parental practices. As many accidents took place during daily tasks, this background situation is 
often also vividly described in the depositions and miracle narrations. Miracles may have been extraordinary occurrences, but they took place in everyday life. Sometimes the depositions offer a glimpse of the flavour of real experience. For example, one morning in the village of Jäder in central Sweden in 1374, the husband of Katerina was lying in bed taking care of their sons, aged eighteen months and four years. The mother was occupied with other tasks when the father stayed with the boys. This morning idyll was broken when the boys were suddenly in pain and soon appeared to be dead. They were recovered through the merits of Saint Birgitta; the mother was apparently the more active in the invocation, but the father participated throughout the miracle process. When Saint Birgitta responded to the prayers by reviving the boys, the parents embarked on a pilgrimage to Vadstena with them. They offered their oblation at the shrine, and both parents were interrogated about the event. ${ }^{18}$

A collective invocation made by both parents was a regular practice in northern Europe. The illness suffered, type of accident and age or gender of the child do not seem to dictate the mode of activity or the active participant. ${ }^{19}$ Furthermore, neighbours seem to have anticipated this shared responsibility in nurturing - it was seen as both parents' responsibility, and negligence was equally seen as a joint failure. Occasionally, a direct accusation of neglect was aimed even at fathers. For example, when the aforementioned infant Rogerus had in the beginning of 14th century strayed from home during the night and fallen into a moat and died, the local official of Conwy accused the father, Gervasius, of deficient custody. Rogerus' parents had been attending a vigil at a church nearby, but this was not seen as an excuse; 'you were not vigilant enough - male custodiasti' was the response. $^{20}$

Fathers were seen as just as responsible, and they could also take the initiative in the field of nurturing alone. ${ }^{21}$ For example, Gudwasti invoked Saint Birgitta's help when his eight-year-old daughter lay mute for nine days without eating. ${ }^{22}$ Similarly, Swenonis, a peasant, was desperately concerned about her daughter, who had been in pain for weeks. The daughter was cured after a plea to Saint Birgitta was made by the father. ${ }^{23}$ A recurrent theme in the depositions of canonisation processes in central and northern Europe is, however, parental collaboration in searching for a cure, invoking a saint and embarking on a pilgrimage following a cure. Only Italian urban spheres seem to have been an exception to this pattern; there women of the same kin group and neighbourhood seem to have collaborated with each other, and nurturing appeared as a feminine duty. ${ }^{24}$ North of Alps, especially among the peasants, this kind of gendered nurturing cannot be found regularly. A case in point is the aforementioned Adam Schirreve, an active participant in the annual pilgrimage made by the whole family to the shrine of Saint Thomas. More than simply participating, many fathers deliberately made their nurturing role visible in the manifestation of their gratitude after a recovered child.

Being a father and a husband was a question of authority, but it was more than that. Fatherhood was one element of masculinity-as-identity; it did not comprise 
only patriarchy but also emotional ties, caregiving and commitment to one's family. Men's commitment to their children affected their identities and sense of self, too. ${ }^{25}$ This was also acknowledged by late medieval authors. For example, Leon Battista Alberti in his Art of Parenting sees fatherhood as a rational craft, yet he also stresses that emotion is equally important in the process of raising children. Fathers needed to experience parenting not only as a responsibility or a burden but also as a joy. ${ }^{26}$

Thus, caregiving could form an element in adult masculinity as well. In societies with high rates of child mortality, a healthy and strong child was a source of pride and happiness, and successful nurturing increased both the father's and mother's status in the community. ${ }^{27}$ Interaction with a saint could require inversions of traditional modes of the manifestation of manliness, as humility and submissiveness were part of the proper invocation. Nevertheless, to take care of one's dependants - even by humbling oneself in front of a heavenly intercessor - was a statement of masculine identity. Therefore, the rituals and practices of invocation to cure an ailing child seem to have been such a moment when the traditional manifestation of masculine authority and power was, quoting Alexandra Shepard, 'eclipsed by other determinants of status and identity'. ${ }^{28}$ Masculine identity was formed not only in opposition to femininity but also in comparison to other forms of manliness and masculinity. ${ }^{29}$

\section{Husband and wife}

From early Christianity on, questions over celibacy and marriage troubled moralists. The hierarchy was encapsulated in the exegesis of the Gospel of Matthew (13:8), which argues that the seed of chastity yields a hundred-fold reward in virgins, a sixty-fold reward in widows, but only a thirty-fold reward in wives: marriage was a morally inferior option to celibacy and virginity. Celibacy's superiority in the teaching was evident, but arguments for the worth of marriage were aired already by patristic authors in late Antiquity. Despite its negative attitude towards sexuality, the medieval church did see something positive in marriage: it was a sacrament that produced offspring and created marital fidelity, summarised as proles, fides, sacramentum. ${ }^{30}$

Nevertheless, the church could not control marriage. Throughout the Middle Ages and early modern period, matrimony remained primarily an agreement between two families, and it was an important institution in securing the family's interests and wealth. The family's interests were therefore of the utmost importance in contracting a marriage - even if the choice of spouse and partner belonged to a person's most private and intimate sphere. Protestant churches relinquished marriage as a sacrament, but in doing so, they also relinquished the notion of the omnipotent virtuousness of virginity. Marriage, although no longer a sacrament, was nevertheless a God-given way of escaping the sins of fornication into which unmarried people would inevitably lapse. In the early modern marriage, sexuality was not a sin - it was a duty. ${ }^{31}$ The change was far from 
abrupt: Dyan Elliot argues that the changing approach was already underway during the Middle Ages: the church renounced prohibitions against sex during lengthy penitential periods in the 12th and 13th centuries. According to Elliot, the emphasis on sexual abstinence during marriage was replaced by an increasing concern for rendering the marital debt by both husbands and wives. ${ }^{32}$ Through marriage, women could gain some religious respect as mothers and wives. Even Mary, the eternal virgin, was made a proponent of marriage: after Jesus was born, she married and also helped plan the Marriage at Cana. ${ }^{33}$

The Protestant Reformations solidified the home as the woman's place and the family as the woman's purpose in life. In Protestant areas, adopting a cloistered life or taking other religious vows lost its meaning as an alternative life path for both women and men, and marriage became the new preferred path for both sexes, the one most people pursued and many ended up adopting. Men could assume other social roles as well, but marriage was often a prerequisite for becoming a master craftsman or a full member of a guild. In rural areas, neither women nor men would be considered autonomous adults until they married; the running of a farmstead needed a husband and a wife, even if, once married, either could be absent for long periods due to war, migration labour or business trips. Marriage was a sign of adulthood, taking on full God-given duties, and, thereby, having rights. For the large part, unmarried men and women worked as hired labour and were ruled by their master and mistress. ${ }^{34}$

Even if men had a wider range of options in terms of social duties than solely becoming husbands and fathers, these events created the core of adult masculinity, a crucial milestone in the life course. A household of one's own gave men power and responsibility simultaneously, as men were regularly held responsible for managing the property of the married couple as well as protecting, educating and disciplining their dependants, which ideologically meant also the wife in addition to the children and servants. Alexandra Shepard, for example, sees manhood as an estate, a positive category of status and a form of privilege. It was based on the age that was between youth and old age, but also on a social position. 'Husbandry' and being a husband, a married head of a household with a respectable social status, were core elements. These age- and wealth-based elements were not enough, however, as behavioural characteristics were required as well, and they, in turn, were often based and defined by religious values. Selfrestraint - avoiding gluttony, lust and pride - was not only a manifestation of devotion but also simultaneously a statement of masculine authority, especially for middling-status men in charge of a household. ${ }^{35}$

Patricia Simons argues that it was virility, not the siring of children, that was the crucial element of manliness and social power for men. Such questions especially troubled celibate men during the Middle Ages, as they could not prove their manliness by sexual acts even if they were considered an essential element of masculinity. Virginity was presented as an ideal model for men as well, and celibate men proved their manliness through the struggle with self-control; they also burned with libidinous desires, but they were able to resist them using their 
willpower and sanctity. ${ }^{36}$ Just like femininity, masculinity and manliness were (re-)created by a performance that was guided by both secular and religious values. They were not the same, but they enhanced each other heavily. This is also manifested in the idea of parenting: a fertile household was a functioning household. Its members did not practise the hidden sins of contraception or abnormal sexual acts. Infertility was a disaster especially for women, but it was considered God's punishment for both men and women. ${ }^{37}$

In theory, the hierarchy of marriage was clear in both the Middle Ages and the early modern period: marriage followed God's order. The husband was the head of the family, and the father had absolute authority in the home. He was to rule, guide and discipline other household members. His job was to see that all the members of the household lived a godly life, had no time to sin and were corrected if they did. The other members of the household were supposed to repay him with deference and obedience. This ideological gender hierarchy did not simply build on the notion that men were supposed to be more rational and sensible and women more easily led by their emotions.

In practical life, women were not seen as worthless beings, and their influence and opinions were not considered insignificant - on the contrary. Teachings reflected the need for women's subordination but also highlighted the importance of wives: a disobedient, unruly and quarrelsome wife destroyed the foundation of a functioning household. ${ }^{38}$ Women held considerable power in ensuring domestic order and, hence, they held the capacity to threaten it. Part of this threatening authority was the power of their words: they were persuasive. Tongue could be a dangerous weapon. Medieval and early modern religious rhetoric associated women and their speech with their bodies - i.e. with their sexuality and sensuality. ${ }^{39}$ Even if talkativeness and nagging were vices typically associated with women and femininity, the situation was not so simple. Not all of women's speech was to be condemned, as women could use their powers of persuasion for both good and bad.

The initiative, talk and actions of a wife are described in a favourable light in a 13th-century exempla recorded by Caesar of Heisterbach. In the story, a usurer's widow travels to the Roman Curia to beg for the right to bury her sinful husband in a Christian graveyard after a bishop had denied her this right. The pope rejects her plea, but the wife does not give up. Instead, she criticises the decision and, according to Caesar, justifies her request by pleading that as a married couple, she and her husband were of the same flesh. She cites Saint Paul: 'For the unbelieving husband is made holy because of his wife' (1 Corinthians 7:14). The widow promises to lead a pious life for her husband, and so she does: she prays, gives alms and fasts. In the end, the pope yields to her request and the widow's acts of piousness release her husband from purgatory. ${ }^{40}$

The words and actions of a wife could also have the completely opposite effect on the salvation of the husband's soul. As a cautionary example, Caesar also tells the tale of a heretic couple. In the exempla, a group of heretics is captured and placed under arrest near Strasbourg. One of the heretics repents, confesses his 
sins and, by the grace of God, is able to carry a fiery-hot iron rod in his hands unscathed, passing the test the accused were subjected to. The man in question is freed and he returns home to tell his wife about the miraculous event. However, his wife is not happy. In a fit of pique, she scolds her husband: "What have you done, you miserable thing, what have you caused? For a moment of pain, you gave up your healthy and holy faith!' 41 Caesar continues the story by stating that anyone could be lured by the snake's voice. So, the man yields to his wife's will and returns to his original faith, and God punishes them both by making them feel the hot iron's burns on their hands. To hide their pain from their neighbours, the couple runs to the nearby forest and howls like wolves. Since exempla had clear didactic purposes, the wicked are punished: both the husband and wife are captured, taken to the city, sentenced to be burnt at the stake and are immolated.

As Caesars' tales show, exempla - educative short stories containing a moral lesson in a simple form - are relevant in revealing both positive and negative stereotypes as well as theological ideas and daily practices. Exempla were used by preachers in their sermons to keep the audience focused and especially to educate the laity that was not learned in theology or philosophy. Therefore, the context of the stories needed to be a familiar everyday situation to which the listeners could relate and recognise. This material was a nexus of learned and lay cultures: exempla were shaped and written by clerics, but the contents needed to resonate with the lived experience and worldview of the audience. ${ }^{42}$

What these stories have in common is that they both display the bond between the spouses and the intertwining of their fates. Moreover, the stories highlight the power of the wife's words and the significance of her actions. Virtuous wives used their powers in their husband's favour, whereas vicious wives dragged others to ruin with them. Medieval and early modern gender constructions associated various qualifiers with femininity, women and womanhood. In matters related to women, it would in fact be more natural to use the plural and talk about femininities. The context of a text's creation and the purpose of the text affected how it defined femininity. Wives were therefore seen in a very different light in practical sermons aimed at married couples than they were in traditional lamentations about the miseries of marriage. ${ }^{43}$

In the early modern period, the importance of the religious role of wives was by no means reduced. In the first century of the Reformation, wives were considered by both the Catholic and the Protestant church to have a great significance in converting their husbands to the correct faith - whichever that was. This was important particularly in 16th-century France and other countries where Catholics and Protestants lived side by side and where interfaith marriages were not only common but also politically necessary. In the 17 th century, Protestants in particular gave up any hope in this matter; they encouraged women to concentrate on raising their children in the right faith instead of trying to convert their spouses. Interfaith marriages remained common in France, but the discussion of interfaith marriages is not relevant in countries with a more unified religious situation. ${ }^{44}$ 
Medieval and early modern women are not portrayed as a unified group or defined solely by their gender and body even within the same source type; women differed from one another due to their individual characteristics and their social background. Sermons, for example, could target different sins depending on the audience's social status. Lower-class people - both men and women - were associated with the body, corporality and sins arising from the flesh, including lust. Middle- and upper-class women were instead thought to be better able to control their bodies and desires; after all, it was their duty to also control others, for example their household's servants. ${ }^{45}$

Women and men of different social classes were also expected to manifest different virtues. Catechisms usually highlight quietness, humility and modesty in actions, words and appearance as women's virtues, but mistresses also had to give orders and run a household. Men also faced different expectations in the Catechisms according to their status and occupation. It mattered - including to one's religious duties - whether one was an aristocrat, a burgher or a commoner, a master or a labourer. ${ }^{46}$

Ecclesiastical writings used allegorical gender depictions for various purposes. God, too, had maternal qualities and Jesus, for example, could be depicted as a mother. Similarly, monks sometimes described themselves as feminine, referring to themselves as the brides of Christ. In doing so, they underlined their own humility: they voluntarily gave up signs of power and their higher position in the hierarchy. They were the humblest of the humble and therefore worthy of salvation. The diverse or ambiguous use of gender images did not alter or remove gender hierarchies; in ecclesiastical literature, masculinity was generally valued over femininity. In everyday life, however, the value scale could be more fluid.

\section{Married life in practice}

In practice, the strict gender hierarchy and the authority of men were not set in stone. With the hierarchy in need of regular renewal, the theme of hierarchy runs through various writings and teachings from Antiquity via the Middle Ages to the early modern period and onwards. Ecclesiastical works discussed this topic for centuries, but secular sources also defined the power relations between the sexes.

Mental authority was not always enough to secure power relations, and hierarchy was sometimes enforced with physical violence. This did not in itself violate medieval or early modern notions of the relationship between a man and wife or some other family member, as violence was, up to a certain point, an accepted and sometimes even expected part of hierarchal relations - be they familial or communal. In fact, several legal acts specifically mention that a man has the right to discipline his wife and children. ${ }^{47}$ This is yet another aspect where legal and religious instructions were in accord, which was seen, for example, in manuals for married life. This genre emerged during the 15 th century, especially in Italy. For example, in his Regole della vita matrimoniale, friar Cherubino of Siena 
recommended that a husband use gentle persuasion and teaching when his wife is committing an offence. Only a wife of rude and poor manners was to be threatened with harsh words. If this did not work, only then was the husband permitted to use a stick to beat the bad behaviour out of his wife, since it was better to harm the body and save the soul than vice versa. Regole della vita matrimoniale, like many other manuals, was written in vernacular, which may imply it was aimed at women readers. Cherubino did grant a similar responsibility to correct one's spouse also to wives. However, they were instructed to use soft words only. If this method did not suffice, wives needed to resort to clerical help. ${ }^{48}$ Similar guidelines can be found in early modern catechisms as well as in household books. ${ }^{49}$ Early modern marriages sometimes showcase how the man's right to discipline his family members could result in violence and marital unhappiness. In Sweden, for example, physically disciplining one's wife, children or servants only became an issue if it caused permanent damage. It was acceptable to slap a maid in the face, but not so hard as to make her deaf. ${ }^{50}$

Traditionally, medieval and early modern culture has been seen as particularly violent, although theories of social civilisation have long been questioned. However, it has been suggested that medieval societies were actually not remarkably more violent than modern ones. They were only violent in different ways. A right to behaviour that modern culture defines as violence was a privilege of those higher up the hierarchy. Visibility was another difference: righteous violence was not shunned or hidden, but openly displayed. ${ }^{51}$

Violence was generally frowned upon in marriage and the family, although it could sometimes be expected of both men and women in the rest of the community, for men especially as a part of a carnevalistic masculinity that required drinking and brawling. Men undoubtedly sometimes brutally abused their wives. Whether domestic violence was more common or more brutal then than it is now is a question that medieval and early modern sources cannot comprehensively answer since reliable quantitative analysis is challenging; statistics on homicides and all cases of domestic violence are not systematic and cases are underreported. It seems, however, that cases of extreme domestic violence were rare. During the Middle Ages, intrafamilial homicide ranged from two to eight per cent of all homicides, while in modern western societies, the proportion can be as high as fifty per cent. ${ }^{52}$ Barbara Hanawalt has studied 14 th- and 15 thcentury English peasants in light of court materials. She cautions that using court cases to study marital relationships risks overinterpretation. Most normal marital relationships never appeared in court, and the relationships found in court records highlight rather more practical aspects of the union: spouses selling or buying land, acting as witnesses or inheriting property. Violent case materials often gain disproportionate attention and should therefore not be used to draw general conclusions about the relationships, emotional bonds or power relations between husbands and wives. ${ }^{53}$

In some cultures, a certain aggressive defence of one's rights and advantages against rival villages and townspeople was expected of both men and women 
from the farming landowning class and the lower bourgeoisie. ${ }^{54}$ These were situations where their authority could be legitimately contested and therefore had to be legitimately defended. If a man had to resort to violence within his family, however, the situation was different. The need to defend his authority within the family already showed a loss of it, and rumours about violence circulating in a village were shameful. Although people were reluctant to intervene in domestic affairs, they would if the situation required it. Generally, the man in question was reproached by the magistrate or parish priest. Countries and towns in which middle-class men were investigated and reproached by magistrates their peers, neighbours, partners and competitors - tolerated violence better. Examples of such areas include German and Italian independent trading towns and Hanse towns. By contrast, attitudes were stricter and punishments harsher in places where the accused was investigated and either punished or conciliated by external authorities - parish priests, dean's or bishop's assemblies, local cathedral chapters, or, in the most severe case, secular court judges. Examples of such areas include Sweden and rural areas in general.

In any case, people generally thought that if a man's domestic issues had to be settled in court, he did not have the authority to deal with them himself. In other words, he had failed either to prevent his family's women from straying sexually or to use suitable means to maintain discipline in the household. All instances of law nearly always sided with the man or the head of the family, who could nevertheless sometimes be a woman. ${ }^{55}$

Resorting to violence was a failure for men in the performance of masculine authority. Although violence was condemnable, it did not cause marriages to dissolve or power relations to shift within the marriage. Marital disagreements were conciliated whenever possible. Conciliation included expressing disapproval of the use of excess violence in maintaining discipline and reproaching the man. Men were sometimes sanctioned to fines or church punishments, but wives were also instructed to show greater humility in future. Parish priests in particular could also advise men to turn to prayer to gain greater self-control. God's will was used as a justification when reproaching either party. Spouses were then encouraged to love one another, live in peace and think of themselves as 'of the same flesh', as both the Bible and catechisms ordered. Becoming one flesh was not just a reminder about the importance of sexual intercourse and especially its reconciliatory effects; instead, it referred to the notion of treating the other person's body as one would one's own: one should not punish one's spouse any more than one would oneself, and one should tend to one's spouse's needs for physicality, food, warmth and nearness as one would one's own.

Despite the importance of conciliation and the disapproval of violence, many researchers have underlined the problematic nature of violent marriages, especially because they were hard or even impossible to leave. Research quotes lengthy and detailed accounts of violent marriages from legal sources to prove women's weaker marital position and their paltry chances of fighting their case in court. In Finland, Anu Pylkkänen pointed out in 1991 that only the grossest 
abuse cases ended up in secular court; the church court managed to successfully conciliate many cases of domestic discord or even violence. Swedish rural courts rarely handled marital disagreements because these were solved in the dean's or bishop's assemblies or cathedral chapters. In many European city states, magistrates handled domestic violence cases. This meant that husbands were judged by their peers - i.e. fellow neighbours - who were likely to support men in the same position and be somewhat reluctant to intrude in their neighbour's business. This could make marital relationships more difficult than when matters were dealt with using outside help, such as the church. ${ }^{56}$

In Protestant areas, divorce was possible, but not easy. The grounds for divorce were strictly regulated: they included adultery, life-threatening violence and desertion. Before a divorce was granted, the couple was advised and sometimes even forced to live together. A formal separation, however, was easier to obtain than a divorce. ${ }^{57}$ In these cases, the couple separated permanently. As marriage was a sacrament according to the Catholic church, humans could not dissolve it; nevertheless, unofficial divorces are known from the Middle Ages, and a marriage could be annulled, for example, for too close a consanguinity. In the early modern period, marriages could dissolve in various ways. In France, it was not uncommon for a couple to claim that they had never entered into matrimony at all. Couples could claim to not have been wed because two legal systems existed side by side: the church emphasised the couple's consent, which was both sufficient and necessary for marrying, while the secular law emphasised that marriage was an agreement between two families and the consent of the families was essential. In a church court, a marriage could thus be annulled due to the couple not consenting, and in a secular court, a marriage could be annulled due to the parents not consenting. ${ }^{58}$ In many cultures in northern and eastern Europe, older notions of marriage based on sex and consummation, which constructed part of the legal bond, were also present in early modern lay, legal and clerical thinking. ${ }^{59}$

In Finland in 1664 (then a part of Sweden), the Turku cathedral chapter granted Per Christersson Broberg, an inspector and a minor customs officer from Turku, a divorce or separation (the wording in the court records could mean either ${ }^{60}$ from his wife, Brita Palm, who was found guilty of adultery. Theoretically, it would have been possible - or maybe legally necessary - to sentence Brita to a capital punishment because of her adultery, but, though legal, such punishments were rarely thought necessary in practice in Sweden. However, the couple could not keep their hands off each other. In 1667, the Turku court of appeal validated the town court's sentence for crimes against chastity because the couple had had a child together after their divorce and committed further fornication with each other even after that. The town court sentenced Per to a fine of 10 taler for the first case of fornication and 20 for the second, and Brita to fines of 10 and 15 taler. In addition, both were issued a church punishment by the cathedral chapter. When the cathedral chapter later revisited the case, it stated that Broberg could no longer abandon his wife and that the divorce had lost its meaning 
when the couple had continued to have sexual relations. However, Broberg was unwilling to live with his wife. To escape this obligation, the cathedral chapter ordered Broberg to prove that Brita had had illicit sexual relations with other men after the couple had got back together after their divorce. According to the chapter's view, he had forgiven the first adultery by moving back in with her. Broberg could not prove his wife had had any other illicit relations, but he was nevertheless unwilling to consent to continuing the marriage. Since the couple had caused 'public indignation', the court of appeal imposed an 80-taler fine on Broberg and church punishment on both. Brita was pardoned the fines because in a way, she had been faithful to her husband after the child had been conceived and the divorce had lost its meaning. ${ }^{61}$

This is not a story of domestic violence, but of the instability of a highly exceptional marriage. As evidenced by this example, it was indeed possible, albeit very difficult, to get a divorce. The story also shows that marriage was in the mid-17th century still - even in urban areas and in the eyes of the Lutheran church - largely about sexual alliances. Finnish folklore also includes various stories, customs and spells that highlight the compatibility and the complementary characteristics of spouses. Laura Stark, who has researched spells used by Finnish women in the 19th century, suggests that the spells related to enhancing sexual compatibility. According to Stark, the emphasis on finding a spouse and recovering from childbirth suggest an equal cultural emphasis on marital solidarity and compatibility. ${ }^{62}$ Peasant marriage researchers stress partnership and common interests that guided the spouses' actions.

Such sources emphasise the peaceable and companionable nature of marriages and the partnership of spouses. People did not marry for love in the modern passionate sense of the word, but spouses were expected to love each other as a charitable duty. In practice marriages were warm and spouses mostly cared for each other. Although romantic love was not a good reason for marrying, spouses were expected to be fond of and to take care of each other. Securing a livelihood and raising children together created a strong bond between spouses. ${ }^{63}$

In northern European peasant marriages, spouses were typically of roughly the same age. Spouses had experience of each other's spheres of life and could better evaluate and appreciate each other's work. Compatibility played an even greater role when people did not marry young, because the couple's empirical world and character had already been formed. Their experiences of the world were not similar, but wide enough to be able to respect each other's duties. Similar stories about finding a compatible partner are, however, also found in southern parts of Europe, for example in Italy, where the situation was different. In southern Europe, the age difference between spouses was often considerable, because men did not marry until they were in their thirties, but girls were married off in their late teens, or even earlier among the nobility. A considerable age difference could further increase inequality in the relationship. ${ }^{64}$

Researchers offer different interpretations of the marriages of patricians and nobles in Italian urban areas. David Herlihy, for one, considers the relationships 
between family members and spouses to have been very idyllic. According to him, wives fell between generations age-wise, thus making them mediators between their children and considerably older husbands. Herlihy also emphasises that mothers had a deep emotional bond with their children. ${ }^{65}$

Focusing on Venice, Stanley Chojnacki also emphasises the role of women as mediators, both between generations and between families; through their marriage, women linked together two families. Chojnacki also highlights women's well-recognised and respected role in caring for and raising children. However, some researchers interpret the status of women very differently. Christiane Klapisch-Zuber has studied Tuscany in the Late Middle Ages and early modern period, focusing on nobles and important merchants. She discusses the same features as the above-mentioned researchers: women married young and stood between families. However, Klapisch-Zuber's interpretation of the situation is completely different. To her, the position of women between two families was proof of their subordinate position: women were exchanged between men. Klapisch-Zuber argues her theory using the financially and otherwise insecure position of widows: if a widow remarried, she could be forced to surrender the children from her first marriage to her deceased husband's relatives. Wives did not belong to their husband's family, and therefore they could not always get custody of their late husband's fatherless children. ${ }^{66}$

Nordic customs prior to the 18th century demonstrate that a woman belonged to her own family and not her husband's, even after they married. Since children were part of both parents' families, a wife could be part of her husband's family through the children if she so wanted. Women could live on their husband's family estate as wives and mothers, but they would have individual rights only to their birthplace. Children were therefore not only women's and men's religious calling but also important for women's financial security. In addition to marriage, having children and keeping them safe through early childhood were important milestones towards 'adulthood' and full independence. According to Swedish legislation, widowed mothers acted as their children's guardians and marriage brokers, but, similarly to Italy, only until they remarried. This did not mean that women were barter goods or commodities; widows were their own marriage brokers and therefore decided whether they wanted to remarry. If they did remarry, however, they became subject to their husband's authority. In such a situation, it was necessary to separate the children's inheritance from the mother's possessions so that the children's inheritance was not put in the hands of an outsider. ${ }^{67}$

This difference in interpretation is also visible in how researchers approach the dowry, the property that women brought with them to the marriage. The purpose of the dowry was to secure a widowed wife's livelihood. Dowry practices varied according to time and place. During the marriage, the dowry could be administered by the husband or sometimes, like in Sweden, by the wife herself. ${ }^{68}$ On the one hand, families competed with each other for power by increasing their daughters' dowry, but on the other hand, potential husbands and their 
families also demanded increasing sums for marriage. In late medieval Italy, this led to a situation that could be interpreted as dowry inflation. According to Klapisch-Zuber, this phenomenon is the culmination of gender inequality, because the lack of an adequate dowry forced many unwed women to join a convent. Moreover, wives who demanded their dowry back when they widowed were considered greedy and evil tyrants who did not care about their children's future. Chojnacki points out that according to legislation, the dowry belonged to the wife. Inflation thus considerably increased women's wealth, which they could control independently as widows. After all, widowhood was relatively common due to the large age differences between spouses. However, families paying large dowries for their daughters also weakened the position of sons: some upper-class sons could not afford to marry because the family wealth had already been used for the daughters' dowry. Families also had to prepare to pay back their daughter-in-law's dowry, should the son die. ${ }^{69}$

Laws, decrees and teachings therefore regulated the lives, everyday routines and worldviews of European women and men in the Middle Ages and the early modern period. Laws and church teachings were nonetheless normative and reflected the author's ideal world more than the reality that people lived. People's liberties, responsibilities, powers and hierarchies were formed differently in different cultural spheres, but what they all had in common was that they were not rigid, unchanged and automatic categories into which people had to cram themselves and their actions and wishes. Legislation and teachings naturally affected and sometimes even directly defined what people could do and think, but inter-family power relations were characterised by negotiation, flexibility and reassessment, if anything.

\section{The violent witch, his whoring sister-in-law and their grieving mother}

In addition to the connections between husbands and wives and parents and children, family relationships included those between the adult generations. Wealth and work, and through them law, played an important role in many family disagreements, but they also influenced the ways people would experience and live out religious convictions in their daily lives. Wealth, work and status also affected the roles of good and evil that people were expected to or could choose to perform. Wealth work and status within the family also had an effect on what kind of experiences they were expected to have, and what they were allowed to experience. This is exemplified in the following story, pieced together from Finnish rural court records.

In 1693, Dordi Matintytär, the eldest daughter of Maria Pertuntytär Sawo from Pomarkku, Finland, sued her brother-in-law Heikki Janckari for defamation: Heikki had called Dordi a whore. Women in early modern Finland would also start their own illicit intercourse cases if they were pregnant or suspected they were, or if rumours of their affairs kept circulating in the community. If 
a child was on the way, women were legally obliged to make the news public, but there were other reasons for taking legal action as well. First, concealing a pregnancy could lead to an infanticide charge if complications arose during childbirth. Second, taking legal action allowed the mother to demand that the father support his child. Third - relevant if only rumours were born of the affair - long-term gossiping often led to the parish priest excluding the couple from communion until the case was closed and any punishments were completed. When the case was closed, the couple could re-enter the community whether or not they married. ${ }^{70}$ In defamation cases women took legal action in such matters fairly often, although there was always the chance that the case could turn against them and result in charges of illicit intercourse. Regardless, a bad reputation had to be cleared. If people were allowed to gossip, rumours would crop up eventually - most likely as accusations of illicit sex. It was thus better to deal with the matter immediately. ${ }^{71}$

At least for family reasons, one could have assumed Heikki would have taken back what he said, but he did not. Instead, Heikki admitted to calling his sisterin-law whore and claimed he could prove that she had kept two suitors at the same time. He implied that both relationships had involved illicit physical contact. Why did Heikki accuse a member of his household? Indeed, they all lived under the same roof: Heikki, his wife (Dordi's sister), Dordi, Dordi's mother and father, and Dordi's maternal grandfather, who owned the sizable place while his daughter ran the business. Families and households were entities in which one member's doings and reputation affected all other members. ${ }^{72}$ It could be that Heikki defamed Dordi out of resentment. He did have a reputation as a shorttempered man. Heikki might also have had a rational reason for his behaviour: it was up to the head of the family to ensure that his family members acted morally and to punish them for any misconduct, if necessary. Any disciplining was usually done within the family, but sometimes the court's help was needed.

In this case, however, Heikki was not the head of the family, even though he was a man living in the same household as his sister-in-law. The head of the family was Perttu Laurinpoika Sawo, the grandfather of Dordi and Heikki's wife. Because Perttu was elderly, he had transferred some of his responsibilities, power and estate representation to his daughter Maria, the mother of Dordi and Heikki's wife. In practice, Maria ran and represented the estate, and she should have made sure her daughters acted morally.

By taking Dordi's alleged misconduct to court, Heikki tried to usurp his mother-in-law's authority, both within and outside the home, and implied that Maria and Perttu were not handling the household members' moral guidance as well as they should. Heikki called his sister-in-law a whore because she had two suitors at the same time and had had sexual intercourse with both. An Anders Skräddare had boasted around the village of having bedded Dordi when the sermon was about the wedding and Cana Galilee. But Heikki had 'on prayer days and other Sundays when everyone else was listening to the sermon at the church' caught Dordi with one Juha Ristonpoika in the bedroom. Once, Heikki had 
even confiscated Juha's shirt as proof that they had not been fully clothed. He implicitly claimed that he had to experience ungodly and licentious behaviour from his family, and, since no-one else took action, he alone was the true godly authority. By taking the matter into court, Heikki tried to validate his experience and impose his interpretation on the rest of the village and the neighbourhood.

When Heikki had confiscated Juha's shirt as evidence, he had been called a thief. Dordi and Juha explained that Juha had taken off his shirt for Dordi to mend. Nothing illicit had happened, except for Heikki taking the shirt and not giving it back. In court, Juha said that although nothing illicit had happened, he had indeed intended to marry Dordi, but nothing had been decided yet. Juha had two reasons for bringing up his intention to wed Dordi. The first reason was common: in Finland at the time, though couples found guilty of illicit intercourse were rarely forced to marry even if they had child together, no punishment was usually imposed if they did marry. The second reason was specific and personal: Dordi was the heir of a wealthy house, and rather than distance himself from a shamed woman, Juha wished to stake his claim for when she eventually decided to marry. This was also the basis for why they demanded the accusations be dismissed: Heikki spread such rumours about her to keep her from marrying, because he was afraid that 'Dordi and her husband would turn him out of the estate because he was only married to the younger sister'. ${ }^{73}$

Clearly, several interpretations could be given to the same events, and different experiences could be created. Some of those experiences were then contested, negotiated and legitimated in community gossip, and eventually in the court trials. The rest of the Sawo household agreed with Dordi: Heikki's only goal was to prevent Dordi from marrying. Heikki himself was only the husband of the younger sister and thus stood a poor chance of becoming the estate's master if the older sister married. At the time, Swedish legislation did not grant the eldest sibling the first right of inheritance, but primogeniture was nevertheless a common custom. ${ }^{74}$ Heikki's chances of ever running the estate were made even poorer by him not being in favour with his mother-in-law or the estate owner. On the contrary, Perttu testified in court that Heikki had 'come to the estate against his will, only because he had seduced the family's daughter'. With all things considered, Heikki was facing the usual fate: he and his wife would eventually have to move out to allow the actual master couple, Dordi and her husband, to take full possession of the estate. Heikki himself had vocalised his concerns publicly in a loud argument with Juha's father, Risto. Heikki had yelled at Risto: 'How could you and your son drive me away from the estate when I have already settled there with my children!'

And as clearly as Heikki had tried to set himself up as the Godly authority, he was now trashed as the ultimate un-godly evil. As the argument continued, Heikki and Juha's father Risto ended up accusing each other of witchcraft. Heikki accused Risto thusly: 'You have bewitched the Sawo son!' Risto replied to Heikki: 'If I have, you were the one who asked for him to be bewitched'. Mikko, Dordi's only brother, had died some time ago. On his deathbed, Mikko 
had had nightmares about Heikki and Risto. Many people heard Heikki and Risto's row, and rumours about Mikko having died due to witchcraft started to spread around the village. At first, suspicions centred on Risto, who had been known as a sorcerer for decades. His witchcraft had been the topic of court cases since the 1680s, and he was also involved in a few active cases. It would have been easy to believe he was the culprit even now. The Sawo family repudiated the rumours and said Risto was not the one to blame for Mikko's death, and that if anyone had cast spells, it was Heikki in his jealousy and anger. ${ }^{75}$

The tide had turned. What began as an accusation of fornication had turned into one of witchcraft against the original accuser. Both accusations combined religious and communal blame and shame with claims of misused power and religiously determined vice.

In 1694, Dordi and Juha were ordered to either marry or take an oath of purification on their innocence (or pay a fine, if they could not take the oath). They decided to marry, which hardly came as a surprise to anyone except Heikki, who seems to have hoped that whereas his premarital affair had opened a way into the household, Dordi's would shut her out of it. This was not to happen. The family clearly sided with Dordi and Juha. When around the same time Risto had to take a group oath of purification in a witchcraft trial that had started in the 1680s, people from the Sawo household were there to swear to his innocence. The whole affair would probably have died down had not Antti Skräddare, Dordi's alleged second suitor, pressed charges against Heikki for defamation. From Antti's point of view, this was a mistake. Heikki stood by his claim that Antti and Dordi had had illicit relations. He even claimed that he had seen Maria and her sister find Antti and Dordi in flagrante delicto in the sauna, and Maria had slapped Dordi's face. When the judge inquired about this, Maria denied remembering any such affair. It soon turned out that Antti had been drunkenly running around the village, boasting about his successes with the heiress girl. Nobody took Antti's drunken babbling seriously, and in the end, the matter was forgotten with no court ruling. ${ }^{76}$

So, Heikki lost his battle. In a final attempt, he even accused Maria of witchcraft. Maria had previously been charged with practising witchcraft with her mother, but Heikki's charge did not stick. Throughout the affair, Maria's position as the head of the household and estate never wavered in the eyes of the villagers or the court. Maria had the full support of her father and the whole estate - with the exception of Heikki, of course - and, to a large extent, the village and court. As the witchcraft trials proceeded, Heikki's situation only grew worse. Despite their public arguments, the whole family still lived on the estate. During the witchcraft trials, Perttu and Maria accused Heikki of a much graver crime, a crime that would be much more likely to end in a death sentence than witchcraft: they claimed that Heikki had physically abused them. It was claimed that Maria had tried to intervene when Heikki had hit and kicked Dordi and pulled her hair when drunk, and Perttu had been met with punches and shoving when he had urged Heikki to rock his crying child's cradle. At first, the matter 
was unresolved because witnesses had not been invited to court in time. Maria withdrew her charge at the next court session - only to renew it a year later. Maria explained that out of a mother's love and 'because she was old and because Heikki Janckari had promised to move out and leave her and her father in peace and treat them with obedience and respect in future, she had helped Heikki as much as she could, even against her better knowledge. However, because Heikki was unwilling to respect his promise', she was now forced to level the charge against him again. Maria said that all she wanted was to live in peace with her husband and father. This meant that Heikki had to leave the estate. ${ }^{77}$

Heikki had tried to find himself somewhere to live, but his reputation as an angry, rowdy and violent drunk - as described to the court by Perttu - had spread far, making it difficult to find a new home. He was probably not wanted in any village in the Greater Ulvila area. It is telling that when Heikki realised he had to leave the estate, he refused to do any work and also forbade his wife from working. At the same time, Heikki began to demand that Maria pay them a full salary for the years they had worked on the estate. This venture failed as well: the court ruled that Maria had already paid the couple what they had earned in addition to their upkeep. It was not until 1698 that Heikki found a farm - it had been abandoned because the previous inhabitants had failed to pay their taxes - and moved in with his wife and children. Out of motherly love, Maria withdrew the charges of witchcraft and violence. As a mother, she said she had been so worried about her son Mikko that it had made her too suspicious, and all she wanted now as an elderly mother was peace.

And so, Maria and Perttu got their peace and Juha and Dordi got their estate, and they seem to have lived fairly happily ever after. The court records do not reveal whether Heikki's wife and children also enjoyed a happy ending. The accusations of whoring and witchcraft were simultaneously very mundane, at the centre of the village life and clearly religious in their nature. They were a way of bringing religious roles into daily life in both virtue and vice. Maria, Dordi's mother, provides a third example of such a religious-mundane double position when she emphasised her role as a good mother grieving for her son - almost like Mary in the priest's sermons. What Heikki had tried to undermine, Maria managed to use to her advantage.

\section{Bad and holy mothers, caring and punishing fathers}

It is no coincidence that Maria Pertuntytär Sawo repeatedly appealed to her 'motherly love', which she used as the reason for both bringing and withdrawing charges against Heikki. Maria and Perttu's attack against Heikki was aggressive, and yet they managed to portray themselves as loving parents and peace-loving elderly people while simultaneously portraying Heikki as a rowdy and violent drunkard who could not even take care of his baby boy. Perttu's story of Heikki abusing him began with a depiction of a crying baby that Heikki had ordered a farmhand to rock. The farmhand did not consider it his duty to soothe the baby, 
and so Perttu told Heikki to lull his own baby himself. Throughout the duration of the case, Perttu kept appealing to his old age and his long-suffering tolerance of Heikki's behaviour due to his age and their family ties. Maria fared even better in explaining how she had stepped in to protect her daughter from Heikki's abuse and been struck herself, ${ }^{78}$ further highlighting the contrast between the parents, who were authoritative and caring, and the adversary, who was a lout, a neglectful father and a bad husband. Perttu and Maria made it look like Heikki deserved to be pushed out of the family community, which was undoubtedly their intention.

Maria earned part of her authority through her role as a mother, which probably helped the people of the estate and village choose her side. As the mother of three adult children, she had proved her experience and capability, and she had become a natural authority for the younger generation. This posed a problem for Heikki: he had to fight an older woman - a mother - for control of the estate, with the community supporting Maria. Yet it was Maria's role as a mother that Heikki attacked when he repeatedly criticised the questionable morals of Maria's daughter, Dordi. Maria had failed to raise her daughter properly, then failed to control her properly and finally failed to punish her properly - or this at least was how Heikki portrayed it. When Maria denied having seen any illicit encounter in the sauna, the court believed her. One could attack a woman by criticising her motherhood and parenthood, but these roles also yielded women authority.

In the Middle Ages and early modern period, motherhood was an uncertain and frightening state, because it involved assuming responsibility for keeping children healthy and raising them. The more absolute power a mother held over her child, the more frightening it was to use that power. On the other hand, women who held great power - like Maria - were usually older women who were tried and tested mothers. Their children had already survived into adulthood and perhaps had children of their own. Motherhood was a milestone for younger women as well, since having children marked the transition into adulthood and signified an important turning point in emotional life. For young women even more than seasoned mothers, motherhood may have been a troublesome tangle of demands and mixed feelings.

Luther's Reformation defined wifehood and motherhood as the religious purpose of a woman's life. Many historians have pointed out that of the two, wifehood is often emphasised in literature because it portrays a subordinate hierarchy more clearly than motherhood. The same historians have viewed the Protestant mother's role in the age of Reformation and Orthodoxy as binding, often even as oppressive. According to the new doctrines, married women could serve God in their everyday lives, but historians state that Luther's model of good motherhood was no easier to follow than that of the Virgin Mary. According to them, impossible expectations were placed on mothers and motherhood. In theory, mothers should have fully devoted themselves to raising their children, but this was not possible because they also had to support their children. Managing a household also came with many responsibilities, some of which took women out of the 
home, not to mention the work women did in the fields, in rearing cattle, at communal baking ovens, in their husband's shops and so forth. These researchers view the discrepancy between expectations and practice as oppressive. They argue that the Reformer's way of making motherhood the only way for women to serve God was a form of oppressing women while praising them. Only one kind of motherhood was acceptable, and it was impossible to fulfil in practice. Women were set up to fail no matter what they did. ${ }^{79}$

Motherhood, like managing a household, was a role that could offer women not only great pleasure but also respect and power. However, it was also possible that something could go badly wrong. Children's lives were fragile. At worst, their short lives could be full of heartbreaking suffering that even their mother was unable to ease. This caused mothers to become anxious and start doubting their worth, which, in turn, could make them aggressive even towards their own children. Few mothers, however, could admit to their inability or aggression, and so women blamed witches for their own failures and sufferings and used them to project their own feelings of hatred and insecurity. In their view, witches turned cream sour and made children fall ill. Women blamed the people they considered witches for their own fears and failures.

According to Roper, a typical witch was an older woman who was past her child-bearing days, and she was therefore thought to be jealous of mothers with children. Ageing women and their barren bodies were also considered signs of death. Instead of feeding children, witches were assumed to suck the blood of babies. Instead of preparing food, they prepared poisons. Instead of cultivating fields, they caused crops to fail. They were everything young women feared. ${ }^{80}$

These thoughts were encapsulated already in the medieval concept of vetula, a negative stereotype of immoral and often lewd old woman. Vetulae featured particularly often in didactic exempla, where they were typically depicted as devious go-betweens, for example, between illicit lovers or between demons and sinners. Quite often they contested clerical authority. The medical lore supported the moralists' teaching, and older women, especially poor ones, were potentially dangerous and poisonous. Post-menopausal changes meant toxic fluids no longer exited their bodies with the menses, and they were thought to be able to poison a child with one look. The medieval concept of vetula may have served as a prototype for the later stereotypical image of the witch. ${ }^{81}$

While motherhood and parenthood certainly were fragile and dangerous, blaming them for the witch trials is a biased view indeed. In fact, the accused were not nearly always older women: in the Sawo case, for example, the accused was a young man. This is also a very narrow view of motherhood. Admittedly, Luther's descriptions of good mothers are depressingly perfect and uniform. These descriptions do not account for any other needs, aspirations or wishes women might have, because they assume that a Christian's only wish is to serve God. Examining the lives of peasant women in early modern Finland, it is obvious that even less than perfect mothering could offer women joy, respect and - like in Maria's case status and power. Maria may have failed in raising her daughters: both seemed 
to have engaged in premarital relations, and both may have had these relations with unsuitable men (Heikki and Antti). Regardless, at least one of her daughters seems to have conducted her experiments as part of what was indeed expected of her - essentially to ensure the compatibility of marriage partners. This daughter ultimately married well and suffered no significant economic or social loss for her experience. With her daughter' status maintained, Maria mother also succeeded well enough in motherhood to use it and the capability it extended to fend off Heikki’s grab for power.

Maria's authority was supported by her father and husband. She ran and represented the family estate from the early 1690s, her father Perttu probably being too old and perhaps too tired for the role. Perttu did, however, occasionally attend court even in the late 1690s. Maria's husband may have been sickly, but he too had represented the estate for some time in the 1680s, until he began to face recurring problems in presenting cases and finally disrupted a court session by turning up drunk. The family and the household chose Maria over other candidates, including men, to represent the estate, and neither the village nor the court objected.

Maria's case also shows how much a woman's position in her household influenced her status in the community. Acknowledged as the head of the estate, Maria had the support of the village community and the rural secular court. Dordi was protected by her family, and that might explain why no witnesses showed up to testify that she had engaged in premarital sex. Researchers often note that in witch trials, a woman's position in her home and family determined who accused her and how. If a woman was respected in her immediate circle and a jealous neighbour tried to use her to attack the whole family, the family would protect her. If a woman was not respected in her family, the family could abandon her. A woman's position in her family also determined the kinds of roles she had outside the family: she might be a mistress or a maid, or she might stay in the comfort of the home entirely.

The events also show how experience influenced the interpretation of the situation: while Heikki accused Dordi of illicit sexual intercourse with Juha, she herself seems to have thought her actions rather normal. In fact, it seems Dordi's conduct was more or less what was expected of her as the daughter of a sizeable farmhouse: to find herself a capable spouse with whom she could in future manage the farm, and, in fact her actions were not unusual. Tiina Miettinen shows that especially daughters of wealthy father could enjoy considerable sexual freedom and still end up in good marriages, both economically and emotionally. On the other hand, previous experience also led the community to judge Heikki as a quarrelsome and untrustworthy drunkard. Nevertheless, both these examples also point that those who had power and wealth were more likely to have experience on their side - and probably more able to get their interpretation and their experience shared by others This power was gendered, although women had a considerable amount of it, through their positions as mothers and household mistresses as well as through village gossip and town rumour. It may 
be that it is only in cases where a man was left powerless that a historian is forced to notice that the important thing was not so much whether women or men were allowed to experience certain things but who had the power, in each situation, to determined which experiences were acceptable, to all individuals of different genders, ages and statuses.

\section{Conclusions}

Family relations and the home were essential in both religious teaching and elements of daily life. Family and home formed some of the social and physical structures that bound individuals to communities and events and interpretations into experiences. Religion and gender were lived out and experienced at home. Secular and religious values regularly supported each other and guided the construction and performance of gender. Being a wife and mother or a husband and father were crucial constituents of adult identity, and these identities were imbued with religious thought and devotional responsibilities. Family roles were a complex matter, though, and theological theories and teaching on gender were often inconsistent and even contradictory. A good wife and mother, for example, also possessed the attributes of a pious Christian: she was meek, humble and obedient, but also dutiful and diligent. However, if the need arose, she needed to correct her dependants. Furthermore, humility and especially self-restraint were also part of being a husband in the religious context. Religion formed the basis for family relations, but it also offered an option for contesting them. Therefore, even if learned ideas generally agreed upon the gender hierarchy, they did not agree on the uncomplicated categories of feminine and masculine. Obviously, the lived experiences, situated in time and society, of medieval and early modern women and men were even more multifaceted.

Since homes and family structures changed slowly, their influence on religion and gender was gradual. It is said that the Renaissance domesticated religion, and the consumer revolution of the time brought a new volume of religious paraphernalia and thereby new forms of religious experience to the home. ${ }^{82}$ This is completely true. However, Reformation ideals of marriage and motherhood were not completely new to society, nor to religion. While the Protestant Reformation's ideals lifted marriage and motherhood up as sacred, the home and the family had long been central to everyday practices of faith and piety. What may have been new was a more forceful divide in the development of the meaning of the home and family in religion: The Catholic church sought to make the holy family as pure and divine as possible while the lay Catholics sought to make it as relatable as possible. ${ }^{83}$ The Protestant churches sought - in varying ways and to varying degrees to extend the purity into the earthly homes and families - the everyday of which the actual members and inhabitants of those families then moulded according to their possibilities, virtues and vices. Home was not merely a built space that formed the material conditions of experience, but an experienced space where the meaning of objects as well as people came from experienced relationships between the 
members of the experiencing community - a community built and defined by those same experiences. In these relationships in the home and the family, the past, the present and the future were intertwined; religion and gender both played multiple roles defining, but also defined by experience.

Of course, different cultural areas of Europe were not alike in every respect. Family structures varied from the southern and eastern multigenerational and sibling households to the north-western nuclear types. Furthermore, no area was uniform: there were large households in England and Scandinavia as well as individual couples with children in nuclear-type households in the Mediterranean. It is essential to understand the contingent nature of all patterns: people lived in many different circumstances. This is essential for understanding the fluctuating nature of gender and piety. Since both were something that people did, performed and lived in connection with other people and other demands around them, something that had to be negotiated, approved and interpreted with others in the community, both gender and piety were also things that could be adapted, appropriated and changed according to situational needs. The communal aspect gave meaning to singular events, turning them into cultural practices, making an individual occurrence into an experience. The next chapter will take these situations from the sphere of the home and the family outside to public religious life.

\section{Notes}

1 On ideas of domesticity, home, and privacy, see Goldberg and Kowaleski, 'Medieval Domesticity', pp. 1-13.

2 The witness statements are available at BAV MS Vat. Lat. $4015 \mathrm{ff} .123 \mathrm{r}-140 \mathrm{r}$.

3 Casagrande, 'The Protected Woman', p. 85, and Jansen, Making of the Magdalen, p. 159.

4 For more on taverns, see e.g. Hanawalt, 'Of Good and Ill Repute', p. 105.

5 On legal practices and duties, see Hanawalt, Ties that Bound, pp. 11-12.

6 Bennett, Women in the Medieval English Countryside, p. 31.

7 Aries, L'Enfant et la vie familiale. On recent discussions of Aries' ideas, see Rosenthal, Essays on Medieval Childhood; Classen, Childhood in the Middle Ages and Renaissance; Katajala-Peltomaa and Vuolanto, 'Children and Agency', pp. 79-99; Katajala-Peltomaa, 'Diabolical Rage', pp. 236-254.

8 Nicholas' case BAV MS Vat. Lat. 4015 ff. 157v-165r; Rogerus' case ff. 188r-203v. For examples about hairpulling, banging of the chest, and violent crying, see e.g. Nicholas testis CXVII, p. 280; testis CII, p. 292.

9 Bouquet and Nagy, Sensible Moyen Âge.

10 Katajala-Peltomaa, 'Parental Roles', pp. 145-155, and 'Fatherhood, Masculinity and Lived Religion'.

11 Grace, Affectionate Authorities; Hanska and Dépéé, 'La responsabilité', pp. 81-95.

12 Il processo per la canonizzazione di San Nicola da Tolentino, testis CCXCIV, pp. 585-586.

13 Beattie, Medieval Single Women; Farmer, Surviving Poverty, p. 40.

14 Miettinen, Ihanteista irrallaan and Piikojen valtakunta.

15 For the motives of families of more modest financial means to choose a religious career for their child, see Hanska, 'Education as Investment', pp. 157-166; for the socio-economic and spiritual motives for practicing ascetism in Late Antiquity, see Vuolanto, 'Children and Asceticism', pp. 119-132.

16 For the allocation of work in 16th-century Sweden, see Pihl, Arbete, esp. pp. 43-105. 
17 Hanawalt, The Ties that Bound, pp. 184-185.

18 Acta et processus, pp. 180-182; for narrations of this case, see also pp. 157, 277-278, 337, 462, 467-468, 547-548.

19 Processus canonizacionis, p. 358. Also 'Vita s. Brynolphi Episc. Scarensis cum processu eius canonizationis, p. 144, 145, 170, 172, 181-182. BAV MS Vat. Lat. 4015 ff. 133v, 162v; BAV MS Vat. Lat. 4025 f. 83r. Katajala-Peltomaa, Gender, Miracles and Daily Life, and Finucane, The Rescue of the Innocents, pp. 99-100, where the author claims that in approximately a third of cases of children's illnesses, fathers made the vow and 'were as deeply involved emotionally as the mothers'. Didier Lett argues that in 12th- and 13th-century French miracle collections, mothers and fathers invoked the saint typically together, and they could play interchangeable roles in the miracle process, in the invocation and the pilgrimage. Contrary to earlier views, he argues for the paternal activity in the case of a sick and injured child. Lett, L'enfant des miracles, pp. 140-141. Christian Krötzl has studied family relations in medieval Scandinavia and argues that 'fathers also participated in various acts of nursing and expressed their devotion to their children'. Krötzl, 'Parent-Child Relations', p. 36.

20 This incident was recorded in the canonisation process of Thomas Cantilupe. BAV MS Vat. Lat. 4015 ff. 189r-203v. For this case, see also Finucane, 'Toddler in the Ditch', pp. 127-148. For other cases with similar interpretations, see 'parententibus ignorantibus et circa alia negocia extra domum habitacionis sue occupatis'. Processus seu negocium, p. 110.

21 On independent paternal activity, see Acta et processus, pp. 128, 130; Processus seu negocium, pp. 98-99; Processus canonizacionis, pp. 322, 330; 'Vita s. Brynolphi Episc. Scarensis cum processu eius canonizationis', pp. 171, 173. The father could have taken the initiative for other family members, too. E.g. Johannes invoked several saints for his wife. Finally, the vow to Saint Birgitta brought relief for the eye disease. Acta et processus, p. 123. On independent maternal activity, see Acta et processus, pp. 120, 125, 128-129, 131, 131, 132, 140, 160. However, in half of these cases (pp. 125, 128-129, 131, 140), it is particularly stated that the mother was a widow, thus explaining the initiative and activity on her own.

22 Acta et processus, p. 132.

23 Acta et processus, p. 128.

24 On the father's role in Italian material, see Katajala-Peltomaa, 'Parental Roles', pp. 145-155.

25 On marriage and masculine identity, see Stuard, 'Burdens of Matrimony', pp. 61-71. See also Neal, The Masculine Self, and Shepard, Meanings of Manhood. On fatherhood and identity in modern-day society, see Marsiglio and Hutchinson, Sex, Men, and Babies, p. 176.

26 For Leon Battista Alberti, parenting was to be based on observations of both the individual child and the composition of the social body. Vitullo, 'Fashioning Fatherhood', pp. 341-354, esp. p. 349.

27 Cf. Katajala-Peltomaa and Toivo, 'Tila ja hoivan käytänteet', pp. 15-28.

28 Shephard, Meanings of Manhood, p. 4.

29 Cf. Bailey, 'Masculinity and Fatherhood', p. 175 for multiple fatherhoods and pp. 167186 for the caring, nurturing, and openly affectionate 'tender father' in the English literature of the 18 th century.

30 Elliot, 'Gender and Christian Traditions', pp. 21-35.

31 An extremely clear interpretation of the second line is offered by Roper, The Holy Household. See also Wiesner, Women and Gender in Early Modern Europe, and Wiesner (ed.), Luther on Women, which include an exhaustive list of literature so far. Luther's thoughts on preaching women are also discussed by Karant-Nunn, 'Continuity and Change', pp. 17-42 and Brauner, Fearless Wives, pp. 179-200. Many studies and articles published at the turn of the 1980s and 1990s discuss women in German towns during the Reformation. Luther's personal and theological attitudes towards women have not been systematically studied; in fact, Brauner is a relatively rare exception. 
32 Elliot, Bride of Christ, pp. 175-177.

33 This line of interpretation is discussed by, e.g. Wünder, He Is the Sun, who does not represent it particularly purely (or at all).

34 Roper, Witchcraft and Fantasy; Eilola, Rajapinnoilla; Ågren, 'Making Her Turn Around', pp. 144-152; Poska, Women and Authority. See also the various articles in Ojala, Migration and Multi-ethnic Communities.

35 Lewis, 'Male Saints', pp. 112-133.

36 Simons, The Sex of Men; Arnold, 'The Labour of Continence', pp. 102-118; Karras, 'Thomas Aquinas's Chastity Belt'. On the construction of masculinity in general, see Karras, From Boys to Men.

37 Daphna Oren-Magidor (Infertility in Early Modern England) has argued that the management and treatment of fertility problems was closely linked to religious beliefs and a strictly gendered social order that functioned together.

38 Krueger, 'Identity Begins at Home', pp. 21-39.

39 On 'sins of the tongue', see Casagrande and Vecchio, I peccati della lingua. The intermingling of clerical and secular discourses as well as elite definitions' infusion into lay institutions is seen in late medieval England where a new category of scold was adapted in the legal records; it was particularly closely associated with women, see Bardsley, Venomous Tongues, pp. 26-44 and 82-89, 126-127.

40 Caesar of Heisterbach, Dialogus Miraculorum, XII, 24.

41 'Respondit illa: Quid fecisti, o miserrime, guid egisti? Ut quid propter momentaneum dolorem recessisti a fide tua sana et sancta?' Caesar of Heisterbach, Dialogus Miraculorum IV, p. 17. In this chapter, Caesar teaches the importance of a true confession. The moral of the story thus has to do with that, and not with a husband and wife's relationship per se.

42 Bremond, LeGoff, and Schmitt, L'Exemplum; Berlioz and Polo de Beaulieu, Les Exempla médiévaux.

43 On sermons, see Schnell, 'Discourse on Marriage', pp. 771-786.

44 Wiesner, Women and Gender; Kettering, Patronage.

45 Sharon Farmer, for one, criticises categorising medieval gender categories in too dichotomous a manner. Church rhetoric formed various gender categories depending on the person's social status, age, wealth, and ethnic background. Farmer, Surviving Poverty, pp. 39-44, 69-70.

46 Hendrix and Karant-Nunn, Masculinity in the Reformation Era; Hallenberg, 'Violence, Masculinity and the State', pp. 132-149.

47 Shahar, The Fourth Estate, pp. 89-90.

48 Cherubino, Regole della vita matrimoniale, pp. 12-13, 23-25.

49 E.g. Becon, Catechism; Brahe; Oeconomia.

50 Karlsson Sjögren, Kvinnors rätt; Hassan Jansson, Kvinnofrid; Lidman, Väkivaltakulttuurin perintö.

51 Cf. Norbert Elias etc. On the visibility of righteous violence, see Brown, Violence in Medieval Europe, pp. 97-99, 288-297.

52 On statistics for late medieval England, see Hanawalt, 'Violence in the Domestic Milieu', pp. 197-214, esp. pp. 198-199; for late medieval France, see Gauvard, De grace especial, p. 573.

53 Hanawalt, Ties that Bound, pp. 206-214.

54 Roper, Martin Luther, Chapter 1; Vilkuna, 'Viina miehen mitta', pp. 92-113; Koskinen, 'Violence and the Peasant Elite', pp. 191-228.

55 Karlsson Sjögren, Kvinnors rätt; Barclay and Carr, 'Women, Love and Power'; Barclay, 'Love and Violence'; Koskivirta, 'Lethal Chastisement of Children'.

56 Karlsson Sjögren, Kvinnors rätt. For a Finnish story, see Eilola, 'Cuckoi päällä kurjanakin'. For the differences between religious and secular law, see Pylkkänen, 'Holhouksen historiaa', pp. 295-296.

57 Karlsson Sjögren, Kvinnors rätt. 
58 Guzzetti, 'Separations', pp. 249-274; Välimäki, 'Vill du äktä denna kvinna?'

59 Korpiola, Between Betrothal and Bedding.

60 A skilije bref.

61 Åbo Hovrätt till Kongl Maijt vol. 4, rotulus oppå criminali saker 1667, 24 May and 15 October.

62 Stark-Arola, Magic, Body and Social Order.

63 Hanawalt, Ties that Bound, pp. 205-209.

64 Hartman, Household.

65 Herlihy, Medieval Households, p. 121.

66 Chojnacki, 'The Most Serious Duty', pp. 133-154; Chojnacki, 'Daughters and Oligarchs', pp. 63-86; Klapisch-Zuber, La maison et le nom, pp. 185-213, 249-261.

67 Pylkkänen, 'Holhouksen historiaa', pp. 98-109; Toivanen, 'Äidillinen valta', pp. 128147; Toivo, Witchcraft and Gender; Andersson Raeder, 'Hellre hustru än änka'.

68 Ågren, 'Decision-making and Retirement', pp. 221-236; Ericsson, 'The Marital Economy', pp. 3-20.

69 Stanley Chojnacki has studied Venice and Christiane Klapisch-Zuber has studied Florence. These geographical differences have undoubtedly affected interpretation just as much as the researchers' different reading of source material. Klapisch-Zuber, La maison et le nom, pp. 185-213, 249-261; Molho, Marriage Alliance. For a contrasting view, see Chojnacki, Women and Men, esp. 198-199, for the historiography of the field, pp. 1-24. For the local differences in women's financial opportunities in Renaissance Italy, see also Cohn, 'Women and Work', pp. 107-126.

70 Pylkkänen, Puoli vuodetta, p. 248 and others.

71 The following story is collected from rural court records in Ulvila on 18-20 October 1693. Vehmaa ja Ala-Satakunta II, KO a 1:431-432. National Archives of Finland, hereafter NAF; Ulvila 14-15 \& 17 September 1694. Vehmaa ja Ala-Satakunta II, KO a 3:282-283 (new page numbers:166v-167). NAF; Ulvila 16 \& 18 June 1694. Vehmaa ja Ala-Satakunta II, KO a 3:239-241 (new page numbers:145-146). NAF, which includes the following quotations. Pylkkänen, Puoli vuodetta, p. 248.

72 E.g. Gregory, 'Witchcraft', pp. 31-66; Liu, 'Le Patrimoine Magique', pp. 13-36.

73 Ulvila 18-20 October 1693. Vehmaa ja Ala-Satakunta II, KO a 1:431-432. NAF.

74 Pylkkänen, 'Forming the Marital Economy', pp. 114-136.

75 'Huru kommer du medelst din son Johan att trängia migh ifràn hemmanet, der jag med mine Barn är bofastblefwen, - Du har ju Sawo son förtollat!' 'Är jagh Sawo sons förgörare, så är du dhen som förgöra låtit!' Ulvila 18-20 October 1693. Vehmaa ja Ala-Satakunta II, KO a 1: 433-435. NAF.

76 Ulvila 18-20 October 1693. Vehmaa ja Ala-Satakunta II, KO a 1:431-432. NAF; Ulvila 14-15 \&17 September 1694. Vehmaa ja Ala-Satakunta II, KO a 3:282-283 (new page numbers: 166v-167). NAF; Ulvila 16 \&18 June 1694. Vehmaa ja Ala-Satakunta II, KO a 3:239-241 (new page numbers: 145-146). NAF.

77 Ulvila 3-5 June 1683. Ala-Satakunta II KO a 1:185-6 (425-v). NA; Ulvila 12-13 March 1694. Vehmaa ja Ala-Satakunta II, KO a 3:35-7 (new page numbers: 42-43). NA; Ulvila 17 \& 19 June 1693. Vehmaa ja Ala-Satakunta II, KO a 1:180-181. NA; Ulvila 16 \& 18 June 1694. Vehmaa ja Ala-Satakunta II, KO a 3:251-255 (new page numbers: 151-153). NA, from which also the quote 'hon eij welat see Janckaris ofärd opa sin alderdohm, utan som han låfwat hemmanet afstijga och sig om annat huusruum försee, sampt lembna henne med sin Man och Fader i roo på hemmanet qwarblifwa, och dem med lydno hädan effter till handa gåå, hafwer hon så myckit möijeligit warit, honom emot sitt bättre wetande hulpit, Men som Janckari sin låfwen icke fullgiöra-'; Ulvila 8-10 January 1695. Vehmaa ja Ala-Satakunta II, KO a 5:26-28. NA; Ulvila 23 \& 25 January 1698. Vehmaa ja Ala-Satakunta II, KO a11: 29v-33. NAF. See also Heijden, 'Contradictory Interests', pp. 355-370 for the relationships between children and their step-parents and parents-in-law.

78 Ulvila 3-5 June 1683. Ala-Satakunta II KO a 1:185-186 (425-v). NA; Ulvila 12-13 March 1694. Vehmaa ja Ala-Satakunta II, KO a 3:35-37 (new page numbers: 42-43). 
NA; Ulvila 17 \& 19 June 1693. Vehmaa ja Ala-Satakunta II, KO a 1:180-181. NA; Ulvila 16 \& 18 June 1694. Vehmaa ja Ala-Satakunta II, KO a 3:251-255 (new page numbers: 151-153). NA; Ulvila 8-10 January 1695. Vehmaa ja Ala-Satakunta II, KO a 5:26-28. NA; Ulvila 23 \& 25 January 1698. Vehmaa ja Ala-Satakunta II, KO a11: 29v-33. NAF.

79 Roper, Oedipus and the Devil.

80 Roper, Witch Craze. See also 'Witchcraft and Fantasy' and Eilola, Rajapinnoilla, for studies on the theory in Finland. For women and motherhood, see e.g. Kettering, Patronage; Poska, Women and Authority. For medieval medical theories on older women, see Jacquart and Thomasset, Sexuality and Medicine.

81 Jacquart and Thomasset, Sexuality and Medicine, pp. 75-76; Miller, Medieval Monstrosity pp. 3, 143-144.

82 Brundin, Howard, and Laven, The Sacred Home, p. 4.

83 Brundin, Howard, and Laven, The Sacred Home, p. 313f.; Forster, 'Domestic Devotion'.

\section{Bibliography}

\section{Unprinted source material}

The National Archives, Helsinki, Finland (NAF): Rural District Court Records: Vehmaa ja Ala-Satakunta I - II.

Riksarkiv, Sweden/Stockholm (SRA): Åbo Hovrätt till Kongl Maijt, vols 2-4.

The Vatican Library, Rome (BAV): MS Vat. Lat. 4015.

\section{Printed source material}

Acta et processus canonizacionis beate Birgitte, edited by Isak Collijn. Uppsala: Svenska fornskriftsällskapet, 1924-1931.

Becon, Thomas. 'The Jewel of Joy'. In The Catechism of Thomas Becon, S.T.P. With Other Pieces Written by Him in the Reign of King Edward the Sixth, edited for the Parker Society. Cambridge: Cambridge University Press, 1844.

Brahe, Per. Oeconomia eller Hushållsbok för ungt adelsfolk. Wijsinborg: Johan Kankell, 1677. Caesar of Heisterbach. Dialogus Miraculorum, edited by Joseph Strange. Ridgewood: The Gregg Press Inc., 1966 (1851).

Cherubino da Siena. Regole della vita matrimoniale, edited by Francesco Zambrini and Carlo Negroni. Bologna: Romagnoli, 1888.

Il Processo per la Canonizzazione di S. Nicola da Tolentino, edited by Nicola Occhioni O.S.A. Rome: Padri Agotiniani di Tolentino and École française de Rome, 1984.

Processus canonizacionis beati Nicolai Lincopensis, edited by Tryggve Lundén. Stockholm: Bonniers, 1963.

Processus seu Negocium Canonizacionis Katerine de Vadstenis, edited by Isak Collijn. Uppsala: Almqvist \& Wiksells, 1942-1946.

'Vita s. Brynolphi Episc. Scarensis cum processu eius canonizationis'. In Scriptores rerum Svecicarum medii aevii 3:2, edited by Claudius Annerstedt, 138-185. Uppsala: Zeipel et Palmblad, 1876.

\section{Literature}

Ågren, Maria. 'Individualism or Self-sacrifice? Decision-making and Retirement Within the Early Modern Marital Economy in Sweden'. In The Marital Economy in Scandinavia 
and Britain 1400-1900, edited by Maria Ågren and Amy Louise Erickson, 221-236. Burlington and Aldershot: Ashgate, 2005.

Ågren, Maria. 'Making Her Turn Around: The Verb-Oriented Method, the TwoSupporter Model and the Focus on Practice'. Early Modern Women: An Interdisciplinary Journal 13, no. 1 (2018): 144-152.

Andersson Raeder, Johanna. 'Hellre hustru än änka: Äktenskapets ekonomiska betydelse för frälsekvinnor i senmedeltidens Sverige'. Ph.D. diss. Stockholms universitet, Samhällsvetenskapliga fakulteten, Ekonomisk-historiska institutionen, 2011. urn:nbn:se:su:diva-60120

Aries, Philippe. L'Enfant et la vie familiale sous l'Ancien Régime. Paris, France: Plon, 1960. [Aries, Philippe. Centuries of Childhood: A Social History of Family Life. Translated by Robert Baldick. New York: Vintage, 1962].

Arnold, John. 'The Labour of Continence: Masculinity and Clerical Virginity'. In Medieval Virginities, edited by Anke Bernau, Ruth Evans, and Sarah Salih, 102-118. Toronto and Buffalo: University of Toronto Press, 2003.

Bailey, Joanne. 'Masculinity and Fatherhood in England c. 1760-1830'. In What Is Masculinity? Historical Dynamics from Antiquity to the Contemporary World, edited by John $\mathrm{H}$. Arnold and Sean Brady, 167-186. London: Palgrave Macmillan, 2011.

Barclay, Katie. 'Love and Violence in the Music of Late Modernity'. Popular Music and Society 41, no. 5 (2018): 539-555.

Barclay, Katie, and Rosalind Carr. 'Women, Love and Power in Enlightenment Scotland'. Women's History Review 27, no. 2 (2018): 176-198.

Bardsley, Sandy. Venomous Tongues: Speech and Gender in Late Medieval England. Philadelphia: University of Pennsylvania Press, 2006.

Beattie, Cordelia. Medieval Single Women: The Politics of Social Classification. Oxford: Oxford University Press, 2007.

Bennett, Judith M. Women in the Medieval English Countryside: Gender \& Household in Brigstock Before the Plague. New York and Oxford: Oxford University Press, 1987.

Berlioz, Jacques, and Marie Anne Polo de Beaulieu (eds). Les Exempla médiévaux: Introduction à la recherche, suivie des tables critiques de l'Index exemplorum de Frederic C. Tubach. Carcassone: Garae/Hesiode, 1992.

Bloch, Howard R. Medieval Misogyny and the Invention of Western Romantic Love. Chicago and London: University of Chicago Press, 1991.

Bouquet, Damien and Piroska Nagy. Sensible Moyen Âge: Une histoire des émotions dans l'Occident médiéval. Paris: Seuil, 2015.

Brauner, Sigrid. Fearless Wives and Frightened Shrews: The Construction of the Witch in Early Modern Germany. Amherst: University of Massachusetts Press, 1994.

Bremond, Claude, Jacques LeGoff, and Jean-Claude Schmitt. 'L'Exemplum'. Typologie des sources du moyen âge occidental. Fasc. 40. Turnhout: Brepols, 1982.

Brown, Warren C. Violence in Medieval Europe. London: Taylor and Francis, 2014.

Brundin, Abigail, Deborah Howard, and Mary Laven. The Sacred Home in Renaissance Italy. Oxford: Oxford University Press, 2018.

Bynum, Caroline Walker. Jesus as Mother: Studies in the Spirituality of the High Middle Ages. Berkeley: University of California Press, 1982.

Casagrande, Carla. 'The Protected Woman'. Translated by Clarissa Botsford. In A History of Women in the West, Vol. II: Silences of the Middle Ages, edited by Christiane KlapischZuber, 70-104. Cambridge, MA: The Belknap Press of Harvard University Press, 1994 (1990).

Casagrande, Carla, and Silvana Vecchio. I peccati della lingua. Disciplina ed etica della parola nella cultura medievale. Rome: Instituto della Enciclopedia Italiana fondata da Giovanni Treccani, 1987. 
Chojnacki, Stanley. 'Daughters and Oligarchs: Gender and the Early Renaissance State'. In Gender and Society in Renaissance Italy, edited by Judith C. Brown and Robert C. Davis, 63-86. London and New York: Longman, 1998.

Chojnacki, Stanley. “The Most Serious Duty”: Motherhood, Gender, and Patrician Culture in Renaissance Venice'. In Refiguring Woman: Perspectives on Gender and the Italian Renaissance, edited by Marilyn Migiel and Juliana Schiesari, 133-154. Ithaca and London: Cornell University Press, 1991.

Chojnacki, Stanley. Women and Men in Renaissance Venice: Twelve Essays on Patrician Society. Baltimore: Johns Hopkins University, 2000.

Classen, Albrecht (ed.). Childhood in the Middle Ages and Renaissance: The Results of a Paradigm Shift. Berlin: Walter de Gruyter, 2005.

Cohn, Samuel K. Jr. 'Women and Work in Renaissance Italy'. In Gender and Society in Renaissance Italy, edited by Judith C. Brown and Robert C. Davis, 107-126. London and New York: Longman, 1998.

Dalarun, Jacques. 'The Clerical Gaze'. In A History of Women, Vol. II: Silences of the Middle Ages, edited by Christiane Klapisch-Zuber, 15-42. Cambridge, MA: The Belknap Press of Harvard University Press, 1994 (1990).

Eilola, Jari. ““Cuckoi päällä kurjanakin; cana alla armaisnakin” - patriarkaalisuus, puolisoiden välinen suhde ja auktoriteetin muodostuminen'. In Arjen Valta. Suomalaisen yhteiskunnan patriarkaalisesta järjestyksestä myöhäiskeskiajalta teollistumisen kynnykselle $v$. 1450-1860, edited by Pia Einonen and Petri Karonen, 100-127. Helsinki: Finnish Literature Society, 2002.

Eilola, Jari. Rajapinnoilla: Sallitun ja kielletyn määritteleminen 1600-luvun jälkipuoliskon noituusja taikuutapauksissa. Bibliotheca Historica 81. Helsinki: Finnish Literature Society, 2003. [On the Bordelines - Boundaries Between the Accepted and the Forbidden in Finnish and Swedish Witchcraft and Magic Cases in the Latter Half of the Seventeenth Century].

Elliott, Dyan. Bride of Christ Goes to Hell: Metaphor and Embodiment in the Lives of Pious Women, 200-1500. Philadelphia: University of Pennsylvania Press, 2012.

Elliot, Dyan. 'Gender and Christian Traditions'. In Oxford Handbook of Women and Gender in Medieval Europe, edited by Judith M. Bennett and Ruth Mazo Karras, 21-35. Oxford: Oxford University Press, 2013.

Erickson, Amy Louise. 'The Marital Economy in Comparative Perspective'. In The Marital Economy in Scandinavia and Britain 1400-1900, edited by Maria Ågren and Amy Louise Erickson, 3-20. Burlington and Aldershot: Ashgate, 2005.

Farmer, Sharon. Surviving Poverty in Medieval Paris: Gender, Ideology and the Daily Lives of the Poor. Ithaca: Cornell University Press, 2002.

Finucane, Ronald C. The Rescue of the Innocents: Endangered Children in Medieval Miracles. New York: St Martin's Press, 2000.

Finucane, Ronald C. 'The Toddler in the Ditch: A Case of Parental Neglect?'. In Voices from the Bench: The Narratives of Lesser Folk in Medieval Trials, edited by Michael Goodich, 128-148. New York: Palgrave Macmillan, 2006.

Forster, Marc. 'Domestic Devotions and Family Piety in German Catholicism'. In Piety and Family in Early Modern Europe: Essays in Honour of Stephen Ozment, edited by Marc Forster and Benjamin J. Kaplan, 97-114. Farnham: Ashgate, 2005.

Gauvard, Claude. De grace especial: Crime, état et société en France à la fin du Moyen Age, 2 vols. Paris: Publications de la Sorbonne, 1991.

Goldberg, P. J. P., and Maryanne Kowaleski. 'Introduction. Medieval Domesticity: Home, Housing and Household'. In Medieval Domesticity: Home, Housing and Household in Medieval England, edited by Maryanne Kowaleski and P. J. P. Goldberg, 1-13. Cambridge: Cambridge University Press, 2009. 
Grace, Phillip. Affectionate Authorities: Fathers and Fatherly Roles in Late Medieval Basel. Aldershot: Ashgate, 2015.

Gregory, Annabel. "Witchcraft, Politics and "Good Neighbourhood" in Early SeventeenthCentury Rye'. Past and Present 133, no. 1 (1991): 31-66. https://doi.org/10.1093/past/ 133.1.31

Guzzetti, Linda. 'Separations and Separated Couples in Fourteenth-Century Venice'. In Marriage in Italy 1300-1600, edited by Trevor Dean and K. J. P. Lowe, 249-274. Cambridge: Cambridge University Press, 1998.

Hallenberg, Mats. 'The Golden Age of the Aggressive Male? Violence, Masculinity and the State in Sixteenth-Century Sweden'. Gender and History 25, no. 1 (2013): 132-149.

Hanawalt, Barbara. The Ties That Bound: Peasant Families in Medieval England. New York and Oxford: Oxford University Press, 1986.

Hanawalt, Barbara. 'Of Good and Ill Repute': Gender and Social Control in Medieval England. New York and Oxford: Oxford University Press, 1998.

Hanawalt, Barbara. 'Violence in the Domestic Milieu of Late Medieval England'. In Violence in Medieval Society, edited by Richard Kaeuper, 197-214. Woodbridge: The Boydell Press, 2000.

Hanska, Jussi. 'Education as Investment. The Childhood of Pietro del Morrone in the Thirteenth Century Abbruzzi'. In Hoping for Continuity: Childhood, Education and Death in Antiquity and the Middle Ages, edited by Katariina Mustakallio, Jussi Hanska, Hanna-Leena Sainio, and Ville Vuolanto, 157-166. Rome: Acta Instituti Romani Finlandiae XXXIII, 2005.

Hanska, Jussi, and Jean-Pierre Dépéé. 'La responsabilité du père dans les sermons du XIIIe siècle'. Cahiers de recherches médiévales et humanistes 4 (1997): 81-96. https://doi. org $/ 10.4000 / \mathrm{crm} .968$

Hartman, Mary S. The Household and the Making of History: A Subversive View of the Western Past. Cambridge: Cambridge University Press, 2004.

Hassan Jansson, Karin. Kvinnofrid. Synen på väldtäkt och konstruktionen av kön $i$ Sverige 1600-1800. Uppsala: Uppsala Universitet, 2002.

Heijden, Manon van der. 'Contradictory Interests: Work, Parents and Offspring in Early Modern Holland'. History of the Family 9 no. 4 (2004): 355-370. https://doi. org/10.1016/j.hisfam.2003.01.002

Hendrix, Scott H., and Susan Karant-Nunn. Masculinity in the Reformation Era. Kirksville: Truman State University Press, 2008.

Herlihy, David. Medieval Households. Cambridge, MA and London: Harvard University Press, 1985.

Jacquart, Danielle, and Claude Thomasset. Sexuality and Medicine in the Middle Ages. Princeton: Princeton University Press, 1988 (1985).

Jansen, Katherine Ludwig. The Making of the Magdalen: Preaching and Popular Devotion in the Later Middle Ages. Princeton: Princeton University Press, 2000.

Karant-Nunn, Susan. 'Continuity and Change: Some Aspects of the Reformation on the Women of Zwickau'. Sixteenth Century Journal 13, no. 2 (Summer 1982): 17-42. https://doi.org/10.2307/2540051.

Karlsson Sjögren, Åsa. Kvinnors rätt i stormaktstidens Gavle. Acta Universitatis Umensis, Umeå Studies in the Humanities 144. Umeå: Umeå Universitet, 1998. [The Judicial Status of Women in 17th-Century Sweden.]

Karras, Ruth Mazo. From Boys to Men: Formations of Masculinity in Late Medieval Europe. Philadelphia: University of Pennsylvania Press, 2003.

Karras, Ruth Mazo. 'Thomas Aquinas's Chastity Belt: Clerical Masculinity in Medieval Europe'. In Gender and Christianity in Medieval Europe: New Perspectives, edited by Lisa 
M. Bitel and Felice Lifshitz, 52-67. Philadelphia: University of Pennsylvania Press, 2008.

Katajala-Peltomaa, Sari. 'Parental Roles in the Canonisation Processes of Saint Nicola of Tolentino and Saint Thomas Cantilupe'. In Hoping for Continuity: Childhood, Education and Death in Antiquity and the Middle Ages, edited by Katariina Mustakallio, Jussi Hanska, Hanna-Leena Sainio, and Ville Vuolanto, 145-155. Rome: Acta Instituti Romani Finlandiae XXXIII, 2005.

Katajala-Peltomaa, Sari. Gender, Miracles, and Daily Life: The Evidence of Fourteenth-Century Canonization Processes. Turnhout: Brepols, 2009.

Katajala-Peltomaa, Sari. 'Fatherhood, Masculinity and Lived Religion in Late-medieval Sweden'. Scandinavian Journal of History 38, no. 2 (2013), 223-244. http://doi.org/10.1 080/03468755.2013.781058.

Katajala-Peltomaa, Sari. 'Diabolical Rage? Children, Violence, and Demonic Possession in the Late Middle Ages'. Journal of Family History 41, no. 3 (2016): 236-254. https:// doi.org/10.1177\%2F0363199016644593.

Katajala-Peltomaa, Sari, and Raisa Maria Toivo. 'Tila ja hoivan käytänteet keskiajalla ja uuden ajan alussa'. Historiallinen aikakauskirja 108, no. 1 (2010): 15-28. http://urn.fi/ URN:NBN:fi:ELE-1493985.

Katajala-Peltomaa, Sari, and Ville Vuolanto. 'Children and Agency: Religion as Socialisation in Late Antiquity and Late Medieval West'. Childhood in the Past 4 (2011): 79-99. https://doi.org/10.1179/cip.2011.4.1.79.

Kettering, Sharon. Patronage in sixteenth- and seventeenth-century France. Variorum Collected Studies Series CS738. Aldershot and Hampshire: Burlington, Vt, Ashgate/ Variorum Cop., 2002.

Klapisch-Zuber, Christiane. La maison et le nom. Stratégies et rituels dan l'Italie de la Renaissance. Paris: Éditions de l'École des hautes études en sciences sociales, 1990.

Korpiola, Mia. Between Betrothal and Bedding: Marriage Formation in Sweden 1200-1600. Leiden: Brill, 2009.

Koskinen, Ulla. 'Violence and the Peasant Elite in Lower Satakunta (1550-1680)'. In Aggressive and Violent Peasant Elites in the Nordic Countries, C. 1500-1700, edited by Ulla Koskinen, 191-228. Cham: Palgrave Macmillan, 2016.

Koskivirta, Anu. 'Lethal Chastisement of Children in Pre-industrial Finland (ca 17001860): Reasons, Practices and Control'. In Interpersonal Violence: Differences and Connections, edited by Marita Husso, Tuija Virkki, Marianne Notko, Helena Hirvonen, and Jari Eilola, 46-66. Abdingdon and New York: Routledge, 2017.

Krötzl, Christian. 'Parent-Child Relations in Medieval Scandinavia According to Scandinavian Miracle Collections'. Scandinavian Journal of History 14 (1989): 21-37. https:// doi.org/10.1080/03468758908579162.

Krueger, Roberta L. 'Identity Begins at Home: Female Conduct and the Failure of Counsel in Le Menagier de Paris'. Essays in Medieval Studies 22, no. 1 (2005): 21-39.

Lett, Didier. L'Enfant des miracles: Enfance et société au Moyen Âge (xiie - xiiie siècle). Paris: Aubiers, 1997.

Lewis, Katherine J. 'Male Saints and Devotional Masculinity in Late Medieval England'. Gender and History 24, no. 1 (2012): 112-133.

Lidman, Satu. Väkivaltakulttuurin perintö. Sukupuoli, asenteet ja historia. Helsinki: Gaudeamus, 2015.

Liu, Tessie P. 'Le Patrimoine Magique: Reassessing the Power of Women in Peasant Households in Nineteenth-Century France'. Gender \& History 6, no. 1 (1994): 13-36.

Marsiglio, William, and Sally Hutchinson. Sex, Men, and Babies: Stories of Awareness and Responsibility. New York and London: New York University Press, 2002. 
Miettinen, Tiina. Ihanteista irrallaan. Hämeen maaseudun nainen osana perhettä ja asiakirjoja 1600-luvun alusta 1800-luvun alkuun. Acta Universitatis Tamperensis 1756. Tampere: Tampere University Press, 2012.

Miettinen, Tiina. Piikojen valtakunta. Nainen, työ ja perhe 1600-1700 luvuilla. Jyväskylä: Atena, 2014.

Miller, Sarah. Medieval Monstrosity and the Female Body. London: Routledge, 2010.

Molho, Anthony. Marriage Alliance in Late Medieval Florence. Cambridge, MA: Harvard University Press, 1994.

Neal, Derek G. The Masculine Self in Late Medieval England. Chicago: University of Chicago Press, 2008.

Newman, Martha G. 'Crucified by the Virtues: Monks, Lay Brothers, and Women in Thirteenth-Century Cistercian Saints' Lives'. In Gender and Difference in the Middle Ages, edited by Sharon Farmer and Carol Braun Pasternack, 182-209. Minneapolis: University of Minnesota Press, 2003.

Ojala, Maija (ed.). Migration and Multi-ethnic Communities: Mobile People from the Late Middle Ages to the Present. Berlin: De Gruyter, 2018.

Oren-Magidor, Daphna. Infertility in Early Modern England. London: Palgrave Macmillan, 2017.

Pihl, Christopher. Arbete. Skillnadsskapande och försörjning i 1500-talets Sverige. Uppsala: Acta Universitatis Upsaliensis, 2012. urn:nbn:se:uu:diva-182392.

Poska, Allyson. Women and Authority in Early Modern Spain. Oxford: Oxford University Press, 2005.

Pylkkänen, Anu. Puoli vuodetta, lukot ja avaimet. Nainen ja maalaistalous oikeuskäytännön valossa 1660-1710. Helsinki: Lakimiesliiton kustannus, 1990. ['Half of the Bed, Locks and Keys'. Woman and the Agricultural Household in the Light of Court Records 1660-1710].

Pylkkänen, Anu. 'Holhouksen historiaa - Edusmiehyydestä huoltoon'. In Suomen oikeushistorian pääiirteet sukuvallasta moderniin oikeuteen, edited by Pia Letto-Vanamo, 98-109. Helsinki: Gaudeamus, 1992.

Pylkkänen, Anu. 'Forming the Marital Economy in the Early Modern Finnish Countryside'. In The Marital Economy in Scandinavia and Britain 1400-1900, edited by Maria Ågren and Amy Louise Erickson, 114-136. Aldershot: Ashgate, 2005.

Roper, Lyndal. The Holy Household: Women and Morals in Reformation Augsburg. Oxford: Clarendon Press, 1989.

Roper, Lyndal. 'Witchcraft and Fantasy in Early Modern Germany'. In Witchcraft in Early Modern Europe: Studies in Culture and Belief, edited by Jonathan Barry, Marianne Hester, and Gareth Roberts, 207-236. Cambridge: Past \& Present Publications, 1998 (1996).

Roper, Lyndal. The Witch Craze. New Haven and London: Yale University Press, 2004. Roper, Lyndal. Martin Luther: Renegade and Prophet. London: Bodley Head, 2016.

Rosenthal, Joel T. (ed.). Essays on Medieval Childhood: Responses to Recent Debates. Donington: Shaun Tyas, 2007.

Schnell, Rüdiger. 'The Discourse on Marriage in the Middle Ages'. Speculum 73 (1998): 771-786.

Shahar, Shulamith. The Fourth Estate: A History of Women in the Middle Ages. London and New York: Routledge, 1983.

Shepard, Alexandra. Meanings of Manhood in Early Modern England. Oxford: Oxford University Press, 2003.

Simons, Patricia. The Sex of Men in Premodern Europe: A Cultural History. Cambridge: Cambridge University Press, 2011. 
Stark-Arola, Laura. Magic, Body and Social Order: The Construction of Gender Through Women's Private Rituals in Traditional Finland. Studia Fennica Folkloristica 5. Helsinki: Finnish Literature Society, 1998.

Stuard, Susan Mosher. 'Burdens of Matrimony: Husbanding and Gender in Medieval Italy'. In Medieval Masculinities: Regarding Men in the Middle Ages, edited by Clare A. Lees, 61-71. Minneapolis: University of Minnesota Press, 1994.

Toivanen, Jenni. 'Äidillinen valta, lapselle kuuluva kuuliaisuus - patriarkaalisuus, leskiäitien ja lasten välisissä suhteissa 1700-luvun loppupuolen Sisä-Suomessa'. In Arjen Valta. Suomalaisen yhteiskunnan patriarkaalisesta järjestyksestä myöhäiskeskiajalta teollistumisen kynnykselle v. 1450-1860, edited by Pia Einonen and Petri Karonen, 128-147. Helsinki: Finnish Literature Society, 2002.

Toivo, Raisa Maria. Witchcraft and Gender in Early Modern Society: Finland and the Wider European Experience. Aldershot: Ashgate, 2008.

Vilkuna, Kustaa H. J. 'Viina miehen mitta: Vapaa-ajalla rakennettu miehekkyys 15501850'. In Näkymätön sukupuoli: Mieheyden pitkä historia, edited by Pirjo Markkola, Ann-Catrin Östman, and Marko Lamberg, 92-113. Tampere: Vastapaino, 2014.

Vitullo, Juliann. 'Fashioning Fatherhood: Leon Battista Alberti's Art of Parenting'. In Childhood in the Middle Ages and the Renaissance: The Results of a Paradigm Shift in the History of Mentality, edited by Albrecht Classen, 341-354. Berlin: Walter de Gruyter, 2005. https://doi.org/10.1515/9783110895445.341.

Vuolanto, Ville. 'Children and Asceticism: Strategies of Continuity in the Late Fourth and Early Fifth Centuries'. In Hoping for Continuity: Childhood, Education and Death in Antiquity and the Middle Ages, edited by Katariina Mustakallio, Jussi Hanska, HannaLeena Sainio, and Ville Vuolanto, 119-132. Rome: Acta Instituti Romani Finlandiae XXXIII, 2005.

Wiesner, Merry E. Women and Gender in Early Modern Europe. Cambridge: Cambridge University Press, 2002 (1993).

Wünder, Heide. He Is the Sun, She Is the Moon: Women in Early Modern Germany. Cambridge MA: Harvard University Press, 1998. 


\section{2}

\section{GENDER IN PUBLIC DEVOTION}

In the medieval and early modern world, inner spirituality was an essential part of religion, but it was nevertheless only one part. Religion was encapsulated in symbols, gestures and rituals - acts that could be inspected by others. Quite often these performances were also meant to be inspected. Proper religious practice, be it Catholic or Protestant, required the use of spaces outside the home. Religion was simultaneously private - intimate even - and communal, visible and public. One could say a quick silent prayer when hearing the bells for Matins ringing and turning on one's side in bed, but religion was on the whole a communal practice. By attending masses, listening to sermons or embarking on a pilgrimage together with one's family, kin and neighbours, a collective identity - a devotional community - was created. Collective performance in a widely accessible space lay at the very core of religion as a lived practice.

The medieval and early modern public sphere in general has been thought of as dominated by men if not men only, perhaps even more so when it related to religion. Ideology often pointed that way. In practice, women could not escape entering the public sphere entirely. Women bought and sold things at markets, baked at communal baking ovens and had grain ground at mills, but they also left their homes to conduct their duties as mistresses or tradeswomen, serve penance, go on pilgrimages and attend church. The image is further complicated by the fact that even if 'private' and 'public' were as spaces and concepts present in the pre-modern world as well, they were not formed following the same categorisations as today. Judicially, medieval and early modern people comprehended space according to the public-private divide: some places were under private ownership and some in communal usage. Sometimes these elements commingled: a marketplace could have been judicially privately owned yet in communal usage. In addition to judicial definitions, the social meaning of a space was crucial. The public and publicity were elements that could be negotiated, contested and 
re-created. In fact, the status of a space and significance of a performance was a social process requiring constant redefinition.

This chapter deals with how life in the public sphere was reflected in terms of what lived gender and lived religion meant to late medieval and early modern people. We focus on people's actions; on symbols, rituals and performances; and on forms of devotion that were intertwined with mundane activities lived among everyday routines and troubles. One major element consists of rituals that were public or deliberately made so. We start with pilgrimages, which were public rituals often having a background motivation in domestic relations and family life. In addition to pilgrimages, medieval and early modern religiosity embraced various other public performances as constitutive elements. They were a way to contest and confirm gendered expectations. A heated topic, for example, was the act of preaching by both lay men and women. It challenged not only gender expectations but also essential societal hierarchies.

\section{Making the private visible: pilgrimages}

A journey to a sacred place was a typical mode of religiosity from antiquity onwards; physical contact with a saint's shrine, relics or other place connected to the cult was crucial in experiencing the sacred. It created a bond between the Christian and the Divine. Being physically present at the sacred place, seeing, hearing and even smelling it, as well as touching its objects, was a particularly relevant element of medieval religiosity. Sensory elements lay at the core of understanding and living out religion, making it tangible and comprehensible, creating an experience of the sacred. The Reformation did not erase the need for a sacred space in religious practice, nor the need for bodily practices and sensory elements. In Catholic areas, pilgrimages as devotional performances continue to the modern day.

Pilgrimages were such a typical form of medieval religiosity that it has been estimated every Christian embarked on such a journey at least once in his or her lifetime. This indeed seems plausible, as the length, background motivation and actual performative practices varied a lot. Some pilgrims travelled to the other side of continent from Finland to Santiago de Compostela or from Iceland to the Holy land, but a journey to the next village or other side of one's hometown could just as well have been meaningful as a religious experience.

Pilgrimages were in principle devotional practices that were available to everyone. Needless to say, geography, age, economic status and health significantly dictated if and how these rituals could be performed, as they required time, effort, and money. ${ }^{1}$ Travels could be tough and even dangerous. They seem to have been quite a gendered phenomenon: men formed the majority of longdistance pilgrims, whereas women were eager to travel to nearby shrines. This was undoubtedly due to quotidian conditions: household tasks, small children and cattle were not easily left behind for longer periods. Therefore, to embark on a journey to a sacred space was not a decision made lightly or purely out of devotion. Some of the risks of travelling outside the home were also gendered: 
only women faced the risk of rape, for example. Some of the hindrances were also based on cultural expectations put forth especially in the moralists' writings. In them, straying too far and for too long from the home and its environs would tarnish a woman's reputation. The basic cultural assumption linking domesticity and femininity influenced the image of women as pilgrims as well: all widely travelled women could be seen suspicious or wanton. ${ }^{2}$

As is the case for the majority - if not all - of medieval and early modern religious performances, pilgrimages were not only a question of piety or spirituality. They were acts of devotion but inextricably linked to the political power relations of the area as well as the social demands and communal position of participants. Travelling to a sacred space could sometimes be considered a liminal moment of direct communication with the Divine. However, pilgrimage was seldom performed alone. They were joint efforts and visible to others: they were public rituals involving formalised, collective and repetitive symbolic action. They communicated various aspects to the travelling companions and congregation at the shrine. They were thus a way to make the private public.

There were many grounds for medieval Christians to embark on a pilgrimage, but interaction with a saint was a major motivation. Petitioners sought the saint's assistance at his or her grave or gave thanks for the help received. Since the saint's aid was sought for within daily troubles, the interaction and invocations for help as well as manifestation of devotion were also closely linked to daily life. By participating in a pilgrimage, the participants could manifest various aspects in their status and identity. Successful nurturing, devotion and even political opinion could be made visible by embarking on a journey to a local shrine.

The visibility of the performance could be enhanced by adopting ascetic modes of travelling. For example, Zona Ricii promised to whip herself while entering the city gates of Tolentino on her way to the shrine of Saint Nicholas of Tolentino. Similarly, domina Cathalina's pilgrimages to the same shrine were a real spectacle, as she promised to take her son Nanczus there as well and lead him with his hands bound. She also promised to offer a wax leg to the saint. A few years later, she promised to do the same with her daughter Andriola, but in addition to leading the girl there with the child's hands bound, she also promised to walk barefoot. The mother would carry a candle as long as the girl to the shrine. Nanczus had fallen from a wall and injured his leg badly, and he had lain unconscious for two days; the doctors had abandoned all hope of his recovery. Andriola, in turn, suffered from falling sickness. Hence, the situation was precarious and both children suffered from a severe condition. ${ }^{3}$

These common devotions also created a freer space for women to operate. They were a way for women to combine their gendered everyday duties with their religious practice, perhaps even increasing their spiritual prestige or social status in the process. One way to combine everyday duties with the practice of faith was interacting with a saint. Saints had supernatural powers, an ability to save and cure, and so people often pleaded for a saint's help in the midst of everyday chores, for example in finding a cure for a sick child. ${ }^{4}$ 
An integral part of this interaction was offering a gift to the divine intermediary in return for help. The gift was often a wax figure in the shape of the ailing limb, but saints were also offered other material and immaterial gifts. For example, the gift could be a promise to name a child after the saint or to give the cured child to the monastery or convent dedicated to the saint. These promises were binding and could not be abandoned lightly. Although churchmen considered decisions about a child's future to be the father's, canonisation processes offer practical examples of such decisions being made by mothers.

Personal penances were also offered as gifts, such as prayers, fasting and charity. Women were free to create a binding bond with a divine intermediary and commit themselves to various religious practices - sometimes even for life - by promising to give annual gifts on the saint's feast day. Some promises of gifts, such as jewellery or silverware, could cause financial distress or power struggles in the home, but all promises affected the whole family in one way or another. Some promises were also noticed outside the home, in the village or town community. Such promises included cutting one's hair, making drastic changes to one's appearance by giving up jewellery and other ornamentations, or making an ascetic pilgrimage barefoot, in a hair shirt or while flogging oneself. ${ }^{5}$

The surrounding community interpreted these manifestations to mean that the person's plea for help had been answered and that the person had formed a particularly close relationship with the divine intermediary. Humbling oneself to public penance could indeed be a way of stressing one's spirituality; being a beneficiary of a miracle could elevate a person's religious standing in the community. ${ }^{6}$ It also signified successful nurturing: help had been received and the patient had been saved. Gifts of thanks to saints therefore linked everyday life and the demonstrations of one's position in the community. Quite often the intention was not, it seems, to break the boundaries of gendered behaviours, but rather to strengthen them and manifest the success one had in fulfilling the expectations of the surrounding society, by being an observant mother, productive nurturer and a devout Christian - even a saint's chosen one.

Even if men could also invoke a saint's help for others and engage in ascetic practices as a counter-gift, both of these features seem to have been heavily gendered in the Italian context. In Italy, it was especially mothers and other relative women who occupied the nurturing role and invoked a saint's aid in the welfare of family members. In other parts of Europe, this responsibility seems to have been more equally shared, as argued in the earlier chapter. Typically, the Italian form of interaction seems to have been the highly public mode of the pilgrimage as a gift to repay a saint's intercession. ${ }^{7}$ As the example of Cathalina shows, such acts were not enough in themselves; she promised material offerings as well. However, as public rituals, these pilgrimages were a form of communication, towards the Divine in expressing one's gratitude, but simultaneously towards the surrounding community. In this case, they told a story of piety and devotion, obviously, but also one of successful nurturing. References to barefoot pilgrimages can be found all over Europe, but walking with one's hands bound seems 
to have been typical solely of votive offerings to Saint Nicholas of Tolentino. A saved and cured child was a source of pride and joy in a society with high levels of child mortality, and the reason for these pilgrimages and Cathalina's successful interaction hardly went unnoticed when she was carrying a human-sized votive oblation and her children were travelling in an ascetic mode.

Cathalina was clearly making her private caregiving role visible by these rituals. This is particularly emphasised in the cure of Andriola, as Cathalina said she made the vow silently in her heart while watching her daughter suffer a seizure. The successful result was, however, presented to everybody. It seems that a pilgrimage was a way to emphasise an accomplishment in the demands of daily life. Religion reinforced both gendered responsibilities and options.

The Italian urban sphere was an eminently suitable context for noticeable modes of pilgrimage. The city states had their own patron saints, and the petitioners had various options, saints and shrines, to choose from. At the same time, the area, and also the cult of saints, was clearly connected with political strife. Cults of patron saints were used in political propaganda, and the choice of intercessor could be a politically laden act. As an example, we may take the aforementioned cult of Saint Nicholas of Tolentino. Didier Lett has estimated that Pope John XXII (1316-1334) may have wanted to reward reliable allies by opening a canonisation hearing on their patron saint's sanctity in 1325. In pre-modern Italy, regions, cities and elite families were in constant aggressive competition with each other. The political turbulence was by no means alleviated by the rivalry of the Guelphs and Ghibellines, the two powerful political factions active in the area, the first supporting the pope and the latter the Holy Roman Emperor. ${ }^{8}$

Canonisation was a papal privilege, and popes also used it in their claims for power; it could be a way to reward loyal supporters by granting official recognition of - or at least opening a hearing to investigate claims about - their patron. Nicholas himself had not been a political figure, nor was he connected to the power struggles between the Guelphs and Ghibellines. He was an Augustinian friar well-known for his humility and ascetic way of life, but his cult and the way his canonisation process was carried out were closely linked to the manifestation of political power. The canonisation hearing was held in the cities of the Marches of Ancona, which belonged to the Guelph faction that supported the pope. The local elite families of Guelph background dominated the hearing as witnesses. Their political adversaries and allies of a more modest background were not interrogated on the matter. ${ }^{9}$ Therefore, when the local elite - both men and women - embarked on a pilgrimage to Nicholas' shrine, they were not only living out their personal piety. Pilgrimages may have been connected to personal tribulations and recoveries, like in the case of aforementioned domina Cathalina. In a politically turbulent era and in an area divided by two political factions, the journeys simultaneously contained political messages proclaiming devotion for a Guelph saint and support for a Guelph city.

Some miracles themselves draw their origin from the political milieu or public incidents. This was the case, for example, in the miraculous liberation of 
Bartholoctus in Montefalco Umbria at the beginning of the 14th century. Bartholoctus, the husband of Andreuctia, had got into a fight and severely injured a man. He was taken captive and put in prison. Andreuctia and Bartholoctus' kin were afraid he was going to face the death penalty, as the injured man seemed to have died. The kinsmen took very practical measures at this point to avoid this outcome: they tried to break into the prison to help Bartholoctus escape. The reason for the aggression and killing is not mentioned, but since the kin was active in course of action, it may have been a wider affair. Late medieval Italian towns were notorious for vendettas between families. A vendetta was considered a legitimate means of resolving a conflict by the participants. Active participation by the relatives may imply this was the case here, as the kinsmen did not show a heightened respect for the official judicial system. Breaking out of prison was not a completely unknown survival strategy, as medieval prisons were not particularly enclosed institutions. For example, family visits were quite common. Bribing the guards may have been more typical a procedure than concretely tearing down the walls, though. ${ }^{10}$

Andreuctia did not take part in this endeavour. It was a risky business and required a lot of physical strength. As a woman, she did not have many legal options to resolve the case either, since the legal capacities of women were heavily restricted in medieval Italy, even if there was no clear consensus on the limits of women's judicial power and the different legal systems were partly contradictory. For example, Roman civil law did not grant mothers the right to serve as the guardians of their children, but canon law did. Ius commune and some authoritative commentators claimed that women could serve as arbitrators or procuratrix for their relatives. ${ }^{11}$ This may have been optional for Andreuctia, but she chose another way to solve the situation. She may have been in a disadvantageous position in regarding physical strength or judicial capacity, but she was by no means helpless or inactive: she resorted to divine help. Andreuctia invoked a local holy woman, Saint Clare of Montefalco, saying: 'Blessed Saint Clare, I beg you to help me in this tribulation so that my husband will not die such a death, and if you do this, I will come barefoot to your grave and bring a wax of two pounds and I will make my husband come there, too'. Andreuctia was soon comforted, as Saint Clare appeared to her urging her to pray to her mother - meaning Clare herself - and her husband would soon be liberated. This indeed happened; the next morning the town council (curia) set him free unharmed.

The inquisitorial committee was interested to know by what means Bartholoctus was liberated - after all, an administrative decision hardly qualifies as divine grace - but the case was nonetheless accepted among the miracles investigated in the canonisation process of Clare of Montefalco. Liberations from captivity were a topos among miracles, and quite often the background element was a sense of injustice; the beneficiary was typically a victim of elite tyranny and imprisoned for unfair reasons. These miracles were not necessarily too marvellous or fantastic; the bounds could have been loosened miraculously, but just as typical was taking advantage of the right moment: the guard could have left the 
door unattended and the captive could have just walked out. ${ }^{12}$ Therefore, Bartholuctus' case was not completely atypical among this kind of miracle. Furthermore, Andreuctia's vow and vision functioned as certifications. Sure enough, this case was not among the most popular or well-known miracles: it did not make it into the miracles listed in the official list of questions, ${ }^{13}$ and Andreuctia was the only witness in the case. However, a barefoot pilgrimage to the shrine while carrying wax was a clear indicator of special status and the occurrence of a miracle. It was a method to make the caregiving role visible, but in addition to that, in this particular case, it was also a comment on family hierarchies. Andreuctia had indeed been a dutiful wife and saved her husband, but by doing this she had also gained control over some matters in family life - she was responsible for their relations with the Divine. Therefore, she could boldly promise to make her husband participate in the ritual of thanksgiving, thus commixing public and private roles, gender hierarchies and inner spirituality with public performance.

Case of Andreuctia and Bartholuctus shows the different ways the public and private intermingled in the field of religion. Another kind of commixture can be found in the following cases. One October at the beginning of 14th century, Cecca was helping her relative with the harvest. She was outside her home and apparently alone. Mediterranean culture had a strong prejudice against women's activities in the public sphere, but even here - not to mention the rest of the Europe - the gendered allocation of space could not be enforced outside the elite. In the lower strata of society, one salary was not enough to provide for the family, so women also had to work for a living. Sharon Farmer has shown that in medieval Paris, for example, the poorest women, even if they were married, had to beg to support their family. ${ }^{14}$ Presence in the spheres outside the home was not necessarily a sign of privileged status - it could be the exact opposite. This unprivileged position was clear in Cecca's case, too, since along came the rasbaldini - a band of seven robbers - who tried to rape her. Cecca was terrified, but she explained that she would have rather killed herself by one of their knives than surrender to them. She recommended herself to Saint Clare and defended herself with such vigour that the robbers did not molest her. ${ }^{15}$

Others were not so lucky. In 1370s, a mad woman - a rape victim labelled as a demoniac - was cured at the shrine of Charles of Blois in Guincamp, Brittany. Reportedly, she was raped by powerful men of 'high society'. Afterwards, due to the assault and her fear that her husband would hate her for it, she lost her mind and became demens ac demoniata. ${ }^{16}$ Brittany was ravaged by the Hundred Years War and violence was endemic. The case may be connected to this background. She had been wandering around aimlessly and had happened on Charles' shrine apparently by chance. We may ponder whether Clare actually helped Bartoluctius and Cecca or whether some other way of explaining the result is more plausible. However, it is indisputable in all these cases that religion offered a coping mechanism in times of distress. This element is particularly underlined in this case of a raped, unnamed woman. In modern terminology, this woman's condition would likely be defined as post-traumatic stress disorder. Medieval people 
were obviously not familiar with such terms, but it was understood that violence and forced sex caused severe anxiety. Religion may have increased the pain, since she had engaged - even if unwillingly - in an illegitimate sex act. Religion, however, also offered a coping mechanism: the intercessions of saints were successfully sought for various afflictions. In this case, religion added an extra layer to the coping mechanism. This woman and the people seeing her had translated her experiences into the language of the demonic by explaining the symptoms in terms of demonic presence. It was a means for the victim to voice her distress, to make it known to the surrounding community, and to allow the community to comprehend and help ameliorate it. ${ }^{17}$ Religion was a way to make private tribulations public. It offered a way to make situations comprehensible and to communicate personal experiences to others.

During the era of the Reformations, many religious ceremonies and rituals had a particularly public nature. Various performative practices often including the laity's ritual participation were traditional already in the Middle Ages. In the struggles over proper religious belief and correct religious practice, the political messages of these customs were heightened. Protestants labelled many Catholic traditions vain or even superstitious, but for Catholics they were a useful tool to activate and incorporate the congregation in the practice of religion. This is concretely illustrated in cases of demonic possession, which were a prominent phenomenon especially at the beginning of early modern era. Demons as active forces were present in Christianity from Antiquity onwards, but some doctrinal and political turning points made their presence more evident. The first milestone was the Fourth Lateran council, which defined the Devil as a fallen angel and thus clearly inferior compared to God. He was a mighty adversary nonetheless, and Christians needed to be careful, as the Devil and his demon minions enticed them to sin and sought to lead them to eternal damnation. The declaration of the annual confession of sins for every Christian, also made at the Fourth Lateran Council, produced an upsurge of warning examples of demonic tricks and the birth to new source material, such as exempla and manuals for confessors.

Since they were superior in their physical and intellectual powers, demons did not only entice people to sin, they could also violently possess an innocent victim's body. Demoniacs and delivery miracles had biblical prototypes, and examples can be found through the Middle Ages. This phenomenon was particularly significant during the early modern era, however, which has even been defined as 'The Golden Age of a Demoniac'. ${ }^{18}$ A case in point illuminating the usefulness of public exorcism for denominational propaganda was the possession and subsequent exorcism of Nicole Orby in 1566. Her case gained widespread notoriety in France, and she was exorcised in a particularly public way by a bishop. The ceremony included long processions in front of large crowds, allegedly 150,000 people. A host in a monstrance was used first to promote a hostile response from the demon inside the possessed girl and then to drive it out. The demonic presence was a personal tragedy, but it also enabled 
the airing of various kinds of religious fears. Simultaneously, the exorcism practices offered assurances of the efficiency of the sacramentals and traditional religious practices. Nicole Orby's case was part of the power struggles between the Huguenots and Catholics: it was the polluted France itself that was purified by driving out the malign spirits within the girl. Since Protestant denominations did not embrace such a variety of ceremonies and were hesitant if not outright hostile towards the sacramentals, they were not equally well equipped to handle public exorcisms: joint prayers and hymn signing were not such an ostentatious display of religious character and authority compared to the Catholics' processions, sprinkling of holy water and oil, relics and official exorcism ceremonies performed by priests. Potentially, because of this, there were far more Catholic than Lutheran - not to mention Calvinist - demoniacs. ${ }^{19}$

During the early modern era, the deliveries for demonic powers were turned from a miracle that was uncontrollable by humans into a priest-ordained ceremony. Women had a prominent role in these public rituals, but as objects, not as independent agents. On a general level, the early modern period witnessed sterner attitudes to women's public devotions and rituals. The church's objective of compartmentalising various phenomena and institutions more strictly may also explain the increasingly negative attitudes towards women's public expressions of faith. This objective was already strong in the Middle Ages, but it only grew stronger in the early modern period. A previously permissive attitude to different manifestations of faith became more controlled and organised, leaving less room for informal initiative and innovation. Devotional guidebooks, prayer books, exemplum collections and catechisms came out in the Middle Ages, but their number grew larger in the early modern period as books became cheaper thanks to advances in paper-making and printing. Codes of conduct and 'oeconomia' - books - collections of maxims and tips with advice on just about everything - were also published for the nobility. The starting point for quite a few of these works was that women should stay in the privacy of the home, away from the public sphere, while the men handled public responsibilities. ${ }^{20}$

At the same time, a public presence was required of women. This presence involved the field of religion but also their roles as carers and household mistresses, representatives of their family and managers of their businesses. These roles were all intermingled. When 'Ménagier' of Paris instructed his newlywed fifteen-year-old bride, in addition to providing food recipes and instructions on growing roses and raising hounds, he advised on proper behaviour in church. Regular attendance at mass was expected, and therefore religious practices took the women outside the home even while religious teaching warned against it: contradictory requirements were inherent in gender construction. When going to mass, the young bride should be attended by respectable matrons and avoid suspect company, especially dishonourable women; she should keep her head high (after all, she was of noble background) but her eyes lowered to avoid contact with other people, especially men. This was not enough, though, as proper 
attire was part of publicity as well. Therefore, the elderly man advised his young wife not to have her hair in disarray or dress in a muddle. Indecent dress, like new fashions, excess ostentation and a disgraceful way of walking, would bring dishonour and shame to her husband and her family. ${ }^{21}$

Ménagier de Paris was a household guide for a wife. It included not only literary loans and narrations, practical recipes and advice but also prayers and direct advice on pious behaviour. These elements were not so eclectic as one might think at first glance; they were all aspects of proper conduct. Religious practices penetrated both the private and public spheres, and together they formed an amalgam that could be labelled the good life - i.e. a respectable, orderly kind of life that follows status and gender expectations. To attain this, public appearances did not need to be completely avoided by women, only appropriately controlled. This kind of advice and regulation was gender-specific but not exclusive; men faced similar expectations of conduct and attire, even if they were not often so clearly propagated.

Some researchers, including Merry E. Wiesner-Hanks, a researcher of early modern women's history since the 1980s, think that people stopped viewing the opinions contained in the conduct books as mere opinions and started taking them as scientific or religious truths. According to these researchers, the notion that women should stay at home was no longer just an opinion to early modern people; it was a simple fact that followed from what women actually did. Women were best suited for minding children and managing the household. As ideologies gradually became lived truths, everyday practices began to reinforce these ideologies. ${ }^{22}$ Lyndal Roper also suggested in 1989 that German teachings focused on Luther's notions of women as wives and not as mothers partly because the woman's subordinate position was perfectly clear in the relationship between the wife and husband. People did not want to muddle this clear hierarchy by exploring the different relationships between mothers and their children or women and their servants. ${ }^{23}$ In Sweden, too, the relationship between the husband and wife was considered to reflect all social relationships between men and women, or in fact any reciprocal relationship in general.

This kind of interdependence between ideologies and real life was enforced by codes of conduct, the works of religious philosophers, confessor's guides and sermon collections. These texts often illustrate teachings with examples taken from real life - or at least examples allegedly taken from real life. People had to be able to believe these stories or imagine themselves in a similar situation. When they did, the stories could be used to describe normal life. It is of course clear that the stories had been chosen and modified to reflect the church's teachings and serve a specific purpose. The clergy's writings took a stricter tone on women in the Late Middle Ages, and speech and writings likewise extolled patriarchal power relations and the withdrawal of women from public life in the early modern period. This rhetoric was caused by women, wives, widows and daughters being more open and daring in public, in the market, in the economy and in religion. ${ }^{24}$ 


\section{Manhood and masculinity as lived practice of religion}

People - men and women - and their activities were also evaluated by social norms and standards in daily life. An important field for closer scrutiny was work, and this could be accomplished by guild systems in towns. In the countryside, there was no such official system, but the evaluation took place as a natural part of people's everyday actions and interactions. Masculinity was similarly expressed in work and competence within it. In rural areas, masculinity was closely tied to farming and the representation of the household in the spiritual world. All around Europe and especially in the rural areas, the official church calendar was complemented by a range of unofficial religious celebrations according to the calendar and harvest year. These formed the platform for regular religious performance, tying daily life, work and devotion tightly together. These feasts included celebrations of church holy days - Easter, Christmas, etc. Spring in particular was a time for various official and unofficial rituals and celebrations to ensure the fertility of the fields. For example, Rogation Days, the timing of which days varied according to the date of Easter, were celebrated with processions to secure the harvest, as was the Feast of the Invention of the Holy Cross (celebrated on 3 May). Typically, these days were celebrated by processions and the Litany of the Saints prayer, but there were also festivities of a less penitential nature. Saint's day celebrations connected to mid-summer festivities, for example, were often celebrated by dancing. Sometimes the disputes between the clergy and laity over proper ritual practice - who was allowed to dance, where, when and in what company - led to accusations of heresy, superstition, and demonic presence. Even if dancers were typically of both genders, these conflicts were gendered: dancing was a corporeal practice seen to lead to promiscuity, a sin typically connected to femininity in the minds of medieval moralists. ${ }^{25}$

Saint's day celebrations were part of the liturgical calendar and the rotation of the agricultural year and seasons. They were important constituents of religion in action and shared public practices. The marking of the passage of time with certain rituals was deeply rooted in agricultural societies. Interaction with the saints had a spiritual meaning, but ritual participation was also a way to mark one's position as a member of the community. These needs were not displaced simultaneously with the intercessory position of saints during the Reformation. For example, in Lutheran Finland, Corpus Christi continued to be an important feast in post-Catholic times. In Jääski in 1686, a villager called Tuomas Pullinen testified against his neighbour, Berend Tappain, and incriminated himself at the same time by explaining that he knew of his neighbour's practices because 'he did well celebrate the same Corpus Christi and Saint Catherine's days, by putting on his best Church clothes, and drinking special beer, with no strangers or servants but only those born at home and their own folk'. Furthermore, Pullinen said that he slaughtered a lamb and cooked it as a dedication to God. ${ }^{26}$ The celebration of most Catholic saint's days had been renounced by the Swedish church at various points around the turn of the 16th and 17th centuries, but 
the neighbours also admitted to celebrating Saints George and Olaf of Norway with special ale. Usually the celebrations included psalm singing and prayers. In a couple of cases, the lay people were also reported to have celebrated an 'irregular Mass' - these descriptions include elements of blasphemy, although at least some of these celebrations seem to have been done in all earnestness. ${ }^{27}$

These features also likened the celebration in various ways - by dress, singing and prayer - to the celebration of holy days in church. The villagers and householders had brewed special beer or ale and drank toasts in honour of the saints celebrated. Such toasts to the Virgin Mary or the saints had been an important part of convivial piety throughout Europe. The late medieval Baltic Sea region was no exception in this, and this form of devotion was particularly important in Livonia. ${ }^{28}$ A special meal was also a common feature: a lamb or calf was slaughtered and prepared beforehand to be consumed in honour of the saint, especially Saints Catherine of Alexandria and Olaf. Sometimes the meals took place in the cattle sheds, sometimes in the house, and occasionally the meals included presentations in specially built or ad hoc offering places. ${ }^{29}$

Finnish historians used to locate these celebrations in the remote and therefore peripheral areas, arguing they were held among the poorest and least educated populace, who were thought to have been subject neither to the proper teachings nor to the control of the church. In reality, however, saint's day rituals were not restricted to the peripheries, nor to the poor and ignorant. They could occur in densely inhabited areas, where the vicar and chaplain could see everything that went on, as well as in the more remote regions, where catechism hearings and sermons were more easily avoided. The participants were often relatively well-to-do freeholding or landowning peasant farmers, sometimes wealthy ones, people who were familiar with the generally accepted manners and rules, even if not formally educated. The types of masculinity the participants represented were therefore at the centre of the rural community, the most hegemonic but also the most contested.

In the Jääski case, for example, the first offender, Berend Tappain, was a local peasant farmer. Whereas all of the ordinary people living in the rural countryside are today sometimes called 'the peasantry', at the time those who considered themselves to hold some sort of ownership or permanent right to a landholding distinguished themselves from the rest of the rural folk as 'the settled folk' - bofast bo(e)nde in Swedish or talonpojat in Finnish (literally meaning 'sons of the house'). Ownership meant different things to different people, and in the eyes of the elites, some of these people were only renting the land from the crown. Nevertheless, the talonpojat, be they freehold or tenant farmers, were the better-off stratum of the rural non-gentry. At the end of the description of the court session, when the parties had been sentenced to fines and the sentence was referred for the approval of the Court of Appeal, the records also note that both parties were 'well able to pay their fines'. This was not always the case, and especially when servant folk and landless people were sentenced, the monetary fines had to be commuted to corporal punishment: consequently, the ability to pay is evidence of relative prosperity. ${ }^{30}$ 
Tappain seems to have worked as a juror in the court sessions of the previous year. In the Swedish secular courts (Finland was a part of Sweden at this time), the office of juror was a position of trust in the community: the same men held the office from one year to the next. Jurors were often used as local experts in court, not only to give an opinion on how matters should be judged but also to act as tools of the crown in carrying out both court decisions and all other sorts of local government business. ${ }^{31}$ Tappain was certainly not poor or ignorant by contemporary village standards, but rather a prominent member of the community. While this tells little about Tappain's religious or other education, it shows both that he was in a position to know how the legal court operated, and that he probably knew very well what kind of customs were generally accepted in his village. It should not be assumed that he naively admitted to behaviour he would think could be considered suspicious. His testimony, therefore, reflects what a good if not major part of the community thought.

These saint's day celebrations were calendar festivals held to cater to the needs of a northern agricultural society well into the Protestant 17 th century. They abound with hierarchical references to kin members and outsiders or landowners and the workforce, and there is much eating and lighting of fires in reference to the sufficiency of food, warmth, light and so on. Travel to sacrificial places is also sometimes recorded, but these rituals away from the homestead lack the sort of domesticity and intimacy of the devotional pilgrimage rituals in the medieval cults of saints in the southern parts of Europe. One of the reasons could be a different gendering of the ritual. This may account for some differences in the expressions of intimacy, since intimacy between men and between women was different. Even when both men and women performed the rituals, however, they worked differently: in southern Europe, many of the pilgrimage rituals were performed by women for reasons that related closely to their personal and family circle - to pray for a miracle or express gratitude for the curing of their children or family members - as part of their care and duties as mothers and wives. In Finland, the regular calendar celebrations were often masculine events, although women did take part in some of them. Whereas people did request cures for their family members or cattle, they seem to have performed the duty as household masters and mistresses, representatives of the household rather than fathers or mothers of a close family. Nevertheless, as we will show below, different methods of personalisation can be seen in the more ad hoc type of saint's celebrations women resorted to when they found themselves in a situation of special, pressing need. ${ }^{32}$

In other words, active religious participation was important to the parishioners. The practices mentioned above used to be labelled bargaining by scholars, and they do have a strong negotiation trait, but they should not be seen cynically as empty of spiritual meaning. They were also about claiming religious agency and subjectivity. It is true that at some points this subjectivity could be representative: one did not always have to take part personally in the action, and one could send a representative, such as a neighbour or a member of the household. 
Representation in household and kin matters - as well as matters concerning the whole village - was an accepted principle in secular matters. The more personal the matter, however, the greater the duty it was to take a personal part in the religious activity. ${ }^{33}$

Both in church and on irregular holy days, a meal was central in the ritual and worship. The participants in the saint's day celebrations drank beer, slaughtered an animal, cooked a meal and ate it. The participants let out their cattle in a specific way and knelt down in prayer. The farmers' own practice was one of tangible action and performance instead of words. ${ }^{34}$ Various levels of agency are evident in the saint's day rituals. Most of the rituals were performed by men, although presumably (it is not mentioned) the meals would be prepared by women. Except for the rituals of letting out the cattle, the place of women and children was standing and watching nearby. Although the examples cited above give scant detail of these specifics, the court records detail the use of magic in the letting out of the cattle, and women and children played a major part. Children made a noise with rattles and horns to frighten away beasts and bad spirits, while women led the cattle out over a fire or stood over the gateposts with their legs spread to ritually protect the cattle. ${ }^{35}$

Many of the descriptions note - as does the one from Jääski - that in the household rituals only 'those born in the house' participated, instead of the whole household with servants, live-in workers and more distant relatives - sometimes even a spouse that had moved in was left outside. The rituals thus marked not only the external boundaries of the household but also those within - the boundaries of kin and family. In marking and enforcing the community, the private celebration also enforced the hierarchies within the household in a way comparable to seating orders in church.

As they relate to daily work and livelihood, the rituals also reinforced a sense of belonging to the community in which the work and rituals were performed. These were rituals where members of a certain household, family, kin group or village were separated from others and marked as belonging together. The same took place on a larger local scale in the church, where the parish was collected into one community among - but slightly different from - other Christians. Sharing a meal is universally thought of as a mark of unity and equality. In the church services, and especially in the communion, the unity of the whole parish was enforced, with both past and future generations being symbolically present. This was important for both the parishioners and the realm, but the unofficial celebrations put smaller communities at the centre. Communality is an oft-noted characteristic of pre-modern religiosity. ${ }^{36}$ The communality was enhanced by tying the religious together with the mundane, especially with drinking. For instance, C. Scott Dixon suggests that attendance at the church service accompanied a visit to the alehouse, which integrated villages, communities and kin. ${ }^{37}$ In rural areas with no alehouses, drinking during the celebration served to integrate the household. ${ }^{38}$

In the religious rituals, gender roles related to the everyday life and livelihood of everyone, regardless of status - those who owned land, those who were either 
born in the house or entered a landed family through marriage, and those serving others. They were reinforced in the sphere of the sacred. This was not simply an ordering of the community into neat rows of pews in the church according to their wealth and status: it was a performance in which everyone had to take their own place and agree to the places taken by others. It is not surprising that although there were women involved, sometimes as very important agents, this was also a sphere where masculine dominance was most visible. It was the husband who represented the household, both in the village and in the sacred.

People could create a private space around them in public places. In church or the marketplace, they could do this by wearing certain apparel, such as a veil or scarf, or by acting in a certain manner, for example by looking down. 'Public' has never meant only the things that are known as opposed to the things that are secret; it has always also meant how things that are shared or public relate to the things that are private. Illicit intercourse and other sins were therefore never private, although modern ideas might lead us to think so. God's collective wrath towards sinners originated in early Christianity, while the transformations of the Reformation era added to its weight: it was a collective duty of the parish to support illegitimate children in the absence of a father, and this made sins markedly the business of everyone.

The interconnection between lived religion and masculinity was a complex matter; independence, authority and responsibility were attributes connected to masculinity. Alexandra Shepard, for example, defines manhood as an estate; it was a positive category of status and a privilege. In addition to sex, it was based on age and social status. 'Manhood' could be acquired (only) by those who were adults between youth and old age, and another important aspect was householding, meaning being a married head of a household with a respectable social status. Derek G. Neal calls this kind of masculinity 'husbandry', meaning middling status men in charge of their household dependants. Managing and controlling the household and chastising its members as needed were thus part of socially privileged masculinity. ${ }^{39}$ However, humbleness and devotion were positive elements in every Christian's position. It could be challenging to be a man of status and pious Christian simultaneously.

However, being a man did not just depend on status markers: behavioural characteristics were similarly crucial. To be the head of a household was not enough, one needed to manage it with honour and prudence. Socially and religiously correct deportment was a status marker especially for those aspiring to a higher social position, like masters in the merchant class in late medieval cities. Early Christian ascetics and the vitae of the Desert Fathers could be used to create an image of the industrious, worthy, esteemed, yet modest merchant. The right kind of masculinity was not easily accessible, however, but it was nonetheless also available to women. Aspiring Christians of both genders needed to overcome the feminine side of their nature, and conquer worldly temptations (particularly sexual lust) in order to maintain a properly spiritual lifestyle'. Thus, only the strongest were able to adopt inner manliness, but the strongest could 
have just as well actually been women. ${ }^{40}$ So, while gendered attributes and status markers were used to create an image of oneself as respectable and devout, the very same identity-making process could have overshadowed them up to the point they were temporarily irrelevant: consequently, gender identities were multiple, particularly in the field of religion.

A particularly multifaceted matter was clerical masculinity, especially the sexuality of these celibate men; it is relatively well attested in the sources, and due to its complexity it has aroused a keen interest among scholars of medieval history. Sexual prowess and virility were crucial constituents of masculinity. Begetting children was a prerequisite for dynastic aspirations and an inevitable component of being the head of the household. However, at least some of the clergy held an elevated social position, even if they were unable to prove their ability in this field. True enough, chastity was a virtue, but it was nonetheless a cultural category - it did not ensue from physical virginity alone, and moral purity could be combined with fighting against sexual lust, or so it seems.

Virginity as a life-long career choice emerged in Late Antiquity; it marked the cultural transition caused by Christianity. In the medieval world, chastity was an important cultural model, but it was also a cultural sore point because of its fluidity and difficulties in categorisation. It was seen as a distinct sexual orientation that had a deep societal impact. Chastity was linked to the sexed body and changes to that body; it was not a lack of desire, but a way to redirect it to matters of the spirit. According to Ruth Mazo Karras, there was a fundamental difference of identity between the sexually active and the chaste. The erotic could overlap with the spiritual, but it was nonetheless distinguished from the carnal. ${ }^{41}$ The importance of this kind of sexual orientation is emphasised further by Jacqueline Murray, who argues it made a decisive difference to a person's identity. According to her, 'Chastity took human beings back to the prelapsarian one flesh that was created in God's image'. Therefore, she sees chastity as a third gender category. ${ }^{42}$

Rather than viewing it as a distinct gender category, the importance of chastity is best attested in the way it multiplied gender expectations and also highlighted the difference between masculinity and femininity. While fighting the sin of lust was of crucial importance for mystics, for men the preservation of their virginity was usually narrated as a form of willpower; it was a contest with and victory over one's own flesh and desires. For men, then, temptation was something to be overcome, and hence it offered an opportunity to prove one's masculinity. Celibate men manifested their masculinity in a struggle for selfcontrol. For women, sexual temptation was more readily a taint, since resistance to temptation was a masculine virtue. ${ }^{43}$

Canon law also forbade the clergy from using violence and physical aggression. This did not always prevent them from participating in the field of war, for example, or from aggressive political manoeuvres. Typically, clerics thought the pen mightier than the sword, and they constructed their identity, created an esteemed position and sought power by rhetorical means. A competition 
between clerical and secular masculinity - among other things - can be seen in the following example from 1370s Sweden.

Hans Smek was a knight of German origin serving the Swedish king, Albert of Mecklenburg (1364-1389). Albert was originally the Duke of Mecklenburg, and German nobles played an important role in the Swedish realm during his reign, causing the Swedish nobility to fear the loss of their privileges. This incident is recorded in the canonisation processes of Birgitta, and it took place in 1374, when her relics were being returned to Sweden from Rome, where she had died. Birgitta had been a member of the high aristocracy and active in politics. Her acts in the political field were not unanimously accepted, nor was her sanctity after her death. Hans Smek was one of those who doubted her saintly position. Seeing the relics being carried, he mocked them, saying: 'What do I have to do with this old hag (vetula) and her remains?' An exclamation of this sort can be taken as a manifestation of his noble status - religious practices and veneration of the common flock were of no importance to him.

In addition to status-based dismissal, Hans had a gendered, even a misogynistic trait in his scorn. Not only did he doubt Birgitta's position as a saint, he also used an exceptionally pejorative term, vetula. It carried strong connotations of, if not magic and superstition, at least sinful behaviour. An old woman, a vetula, was an archetype of a notorious sinner in both moral and vernacular texts. ${ }^{44}$ In addition to moral condemnation, the image of the vetula was reflected in medical discourses where older menopausal women could be seen as dangerous or even poisonous, since the toxic fluids no longer exited their bodies with their menses. Later, the vetula also served as a prototype for the witch. Thus, this was not a minor insult. The punishment needed to be in accordance with the severity of the insult, and so it was. Following his defiling words, Hans became so crazed that he not only saw a multitude of demons but also fled to a forest, took off his clothes, kneeled in front of a tree and whipped himself severely. Later he rode to a church, closed the doors and flagellated his body and head with sticks and whips, shouting at his friends: 'You accursed robbers and oppressors (tyranni), you have spoken just as badly of that blessed domina Birgitta as I have, you are just as deserving of malediction and the company of demons as I am'.

Birgitta's cult was used in political endeavours after her death and the quantity and quality of punishing miracles testify to the firm resistance as well as the active shaping of her image as a saint, the latter being done by the Vadstena clergy recording the miracles. Her image was constructed in the canonisation process as a saint fighting against demons and urging Christians to confess their sins. ${ }^{45}$ Birgitta's position in the hierarchy was clearly established, but the case constructed and reflected earthly hierarchies as well. This knight was forced to take off the signs of his elevated social position: without his clothes he was only a man, not a member of the elite; his kneeling and flagellating further emphasised his self-abasement. Even if he himself carried out the performance of humility, it can hardly be defined as voluntary.

The political element is explicit: Hans Smek's peers were likely other Germans, and to label them tyranni is an accusation of bad and illegitimate government. 
Similarly, to label this noble entourage as robbers was an accusation, likely of robbing Vadstena and competing for economic wealth and privileges. By the time of the incident, the position of Vadstena was not yet established or secure, since the abbey was not dedicated until 1384. The local clerics recording this case and other miracles had been closely associated with Birgitta; they were learned men of authority and experience. Recording these details was not a mere coincidence; the case was famous and these exclamations were part of different versions of it. Hans Smek and his companions were considered to compete with the abbey and to seek to suppress its position and influence. Later, during the 15th century, the abbey became an influential centre where the council of the realm met several times; the priest brothers held considerable political authority and used their sermons to deliver political advice. ${ }^{46} \mathrm{~A}$ similar kind of aim can be detected in this earlier material as well. The ethnic dimension of the political struggles and the activity of the Vadstena clergy in this field are also reflected in Vadstena Abbey's memorial book. A later note depicting these years describes the situation in a following manner: 'then birds-of-prey occupied the hilltops since the Germans tyrannised the country'. ${ }^{47}$

With the inherent ethnic dimension, the elite's struggle for power is clearly demonstrated in this case. Nevertheless, it can also be read in the context of competing ideas of masculinity. As this case is recorded in the canonisation process of Birgitta, humiliation caused by demons was not the end of it. After a while, Hans regained his senses and promised to make a pilgrimage. First, he intended to make a journey to Aachen in his home country, but he was severely re-afflicted. He got better only after understanding that he needed to pay tribute to the very same relics he had reviled. With the utmost humility, he approached Vadstena Abbey and the relics of Saint Birgitta, and then he was cured. Humility was an underlined element of the narration, but the delivery not only required self-abasement in front of Birgitta's relics but also in front of the Vadstena clergy as well.

Hans could not perform the accustomed role of knight after he had violated the cosmological hierarchy. Both demons and saints had power over humans. Adult men of high social status were not the most typical victims in cases of demonic possession in general. Nevertheless, when recoding miracles for Birgitta's canonisation process, the Vadstena clergy did not shy away from this categorisation. They used it to manifest the superior powers of Birgitta as a saint and the importance of Vadstena Abbey as a sacred place housing the relics of this heavenly intercessor. Competing here were not only the disrespectful Christian versus the saint commanding demons but also two different types of masculinity as well. On the one side, there was the rich and powerful but sinful and disrespectful knight; on the other side, there were the obedient and devout clerics who lacked many typical means to manifest masculine status and prove their manliness. However, the latter had an overpowering back-up force: their gendered patron saint. Wealth and social prestige did not ensure the proper performance of ideal masculinity, and virility and sexual prowess were but one aspect 
of it. The clerics in charge of recording this case seem to have had various methods of identification, also concerning gender. They relied on social prestige and links to the ruling class - that is, Birgitta and other Swedish nobility - taking advantage of Birgitta's cult for their own enterprises. It was Birgitta, the heavenly domina who was at the top of the hierarchy, and the priest brothers in Vadstena Abbey were merely her humble servants. Furthermore, in social hierarchies they were subservient to the abbess, who was in charge of the abbey. These humble servants were nevertheless able to differentiate the righteous from the sinners and define piety and proper ritual practice, for example whether a pilgrimage and other acts of gratitude were sufficient or not. The priest brothers were on the same side as the heavenly intercessor in opposing blasphemers and disrespectful sinners. Gender was an important element in this, since they, as priests, were able to spread the proper word of God - including propagation for their patron saint. They did not possess worldly treasures, but their abbey did. It was their duty to guide others as well to the path of salvation. An indispensable part of this was the simultaneous promotion of the cult of their patron, domina Birgitta and the position of their abbey.

During the Middle Ages, celibacy was a well-established and highly esteemed yet debated gender category for both men and women. It was not an unproblematic one, as Ruth Mazo Karras has shown. Gender took one queer step further in ideal models and the imagination. The idea of virgins as brides of Christ emerged already in Antiquity, but in the Middle Ages it could be applied to monks as well. It was at the same time an affirmation of a close personal relationship with Christ and a comment on gender hierarchies. If the last shall be the first; are not those most deserving of redemption the ones who had voluntarily renounced worldly positions? At the same time, God could be depicted as a mother and Jesus as nursing the faithful from the wound in his side. The bodily, sexual, gender and interconnected hierarchies were in flux: they were negotiated and re-organised time and again.

A time for reorganisation took place yet again during the Reformation, when Protestant areas rejected the idea of clerical celibacy and the ideal of celibate masculinity. Male and masculine qualities focused even more clearly on patriarchal power and control in connection to family and marriage, even in the case of the Protestant clergy, which now sought to distance itself from the Catholic clergy. As the mundane everyday was sacralised in Lutheran social teaching, the sacred was also made much more mundane. This left less space for sacred weakness that could find bodily or erotic expression. It nevertheless left room for gendered role-twisting and the purposeful fussing of ideals, but this was to take different forms that emphasised control and intent rather than passion. Such paradoxes were also an important part of the portrayals of important religious figures such as Luther, Melanchton and a number of Jesuits and later Protestant Pietists whose life narratives went through sinfulness, contrition, ascesis and justification. Again, to be justified meant that one first had to be a sinner - to be the highest among the saved, one had to be the lowest among the sinners. 
An example of the meaning of the ostentatious stripping of traditional signs of masculinity for early modern piety is provided by the early radical Pietists at the turn of the 18th century in Finland (then part of Sweden). Laurentius Andears Ulstadius was the son of the vicar of Ii parish and rector of the school in Oulu town in northern Finland. Like his father, he had had a formal education to become a priest. However, he failed to gain a chaplaincy in the parish of Oulu in 1681, and he started to become increasingly depressed. As he struggled to come to terms with failing to get the tenure, he fasted, kept a nightly vigil and read religious literature, including the works of the German Pietists. The result was that he drifted away from his regular studies and his physical health deteriorated fast. The feverish young Ulstadius used gunpowder to blow up the philosophical library he had inherited from his father, and he wanted to go through public confession and absolution. The new vicar of Oulu refused such public manifestations, which led to Ulstadius becoming convinced of the utter depravity of the official church. He resigned from the clerical estate at the end of 1682.

After his illness had subsided, Ulstadius travelled to Turku on the south-west coast of Finland. He begged the Cathedral Chapter to allow him the public confession he felt he needed. The Bishop of Turku seems to have been as reluctant as the vicar of Oulu was, and it took until 1685 before it was organised. Thereafter, Ulstadius embarked upon ascetic repentance. He let his hair and beard grow wild - Finnish 17th-century clergy traditionally had long hair and long beards, but they were styled and well kept, not wild and unkempt - he refused to have his clothes washed or mended so that eventually he was dressed in rags, and he appeared at every service held in the cathedral. ${ }^{48}$

On one of these days, in the summer of 1688, he interrupted the sermon, shouting accusations and cursing both the church and the clergy for their spiritless depravity, greed and laziness. As he was arrested and physically detained in the church, his ragged clothes fell off and, for a while, he stood there naked screaming that the collective shame of the clergy would yet one day be exposed like he was at that moment. He turned the physical actions of the town guards into a symbolic action of his own with quite the opposite meaning. He continued this process: after having first been sentenced to penal labour, he was pardoned in 1719, and he stayed voluntarily in the prison of Smedjegård, Sweden.

Laurentius Ulstadius was not the only one of his kind. His friend Petter Schäfer, from a bourgeois background, joined Ulstadius. Like Ulstadius, Schäfer renounced his university degrees as signs of worldly ambition and vanity, and he soon became a leading figure of the small movement. As Ulstadius' actions were already under investigation, Schäfer was soon included and his views were pronounced non-orthodox. He was imprisoned, but since he acted remorsefully and begged for mercy, he was released on the condition that he renounce his views publicly. Instead, Schäfer fled to Russia, the Netherlands, England, German areas, and even to North America. As he travelled, he met other religious critics such as Philipp Jakob Spener. In 1700, Schäfer fell ill after a radical fast. 
The illness brought on a spiritual crisis, and Schäfer decided to return to Turku, despite the danger involved, in order to preach his truth.

Like the young and eager Jesuit missionaries in all corners of the world, Schäfer courted martyrdom. Schäfer had begged for mercy at his heresy trial, but as he had fled, the case had never been resolved. Upon returning, he retracted what he now considered a dishonest plea. In 1707, he forced the Court of Appeal to hear his case of conscience: the Lutheran Church had, in his view, become heretic; it would bring damnation on the whole of Finland, and everyone should repent before the 1000-year Kingdom descended. The Court of Appeal sentenced him to death in 1709 , but the sentence was commuted to life imprisonment, first in Turku, and later on, after the Russian invasion of Finland in 1713, in Gävle. During his imprisonment, he kept a diary describing his ascesis, temptations and challenges - including breaking his fast, masturbation and relationships with at least four different women - in graphic detail. He wrote of his anxiety because of his sins and the very practical measures he endeavoured to take to combat temptation: for example, he refused to open the door to those who brought food or carnal sights into his cell. In 1712, he performed a marriage ceremony himself in order to marry Anna Wargentin, but according to his diary, the relief from temptation was only partial. He died in prison in $1729 .{ }^{49}$

Early modern manhood was normally defined by virility, self-control and selfdiscipline - the latter especially among the upper classes. However, the Radical Pietists such as Ulstadius and Schäfer turned the loss of control and admissions of utter sinfulness into virtues in their own right. Humility and (self-)humiliation became matters of pride, and the understanding of one's own sinfulness, combined with the stripping of worldly status, became forms of proving one's salvation and religious status. In this sense, the physical illnesses that both men suffered were not only triggers of mental crisis. They also started the forceful decline of everything that was considered traditionally masculine in their surroundings: physical vigour, strength and stamina. Whereas the illnesses ended these young men's youthful potency in a physical and worldly sense, a radical religious interpretation turned the same loss into a symbolic beginning.

Nevertheless, the ascetism of the Radical Pietists was fundamentally different from that of the earlier Lutherans. In Lutheran orthodoxy, self-doubt was a natural and essential part of faith and salvation, the basis upon which true faith lay. In the medieval tradition, Ascesis was part of a long-term practice, the meaning of which was to learn to communicate with God. The Radical Pietists were perhaps closer to the medieval tradition, because they rejected the idea that a person could be simultaneously sinful and justified, and they separated their own penance from that of those not yet born-again. ${ }^{50}$ What is relevant here is that outward signs of masculinity, their meaning and their veracity were irredeemably intertwined with expressions and experiences of religion and faith.

Obviously, masculinity was not one single category; it was bound to culture and society, and defined differently in each context. Even idealised masculinity was not a single unity - it has variations and nuances. Indeed, we should rather 
speak of 'masculinities' in the plural. Lived religion, as a concept that combines ideals and norms with practices and performances, offers a suitable perspective for the analysis of masculinities; it is sensitive to both ideological underpinnings and individual enterprises. Even so, lived religion's perspective on masculinity was problematic. In ideals pertaining to the whole pre-modern era, both the cosmos and societal relations were built on hierarchies, and everyone had their specific place in it. Clear enough, supernatural powers - whether benign or malign, i.e. gods, God, angels, saints or demons - were superior in power in relation to humans. Worship included due respect and personal humility; this, in turn, was not always in accordance with worldly hierarchies. Combining the display of an elevated social status with devotional practices could be an anxious enterprise.

\section{Lay people talking about religion}

Religion was a social process connecting individuals and communities; it was played out within the web of power relations inherent in medieval society, as the example of Hans Smek demonstrates. It was, however, only one of the many processes, and the interconnection of religion and political power is well established. Religious and secular life were inseparable in the Middle Ages and early modern period. The church's main sphere was religion, but it was also involved in public life. Crises, be they personal, such as family emergencies, or communal, such as the Reformation, the wars of religions or other symbolic peaks of change, often forced a merger of the private and the public for those involved.

Laypeople did have a need and desire to discuss religious matters, as is demonstrated by the rise of lay preachers during the Reformations. The ability to teach and preach gave a person great religious power - perhaps even too great a power, because all Protestants soon started to take a very uncomplimentary attitude towards these expressions of general priesthood. Laypeople in general were supposed to read religious writings, but not preach, teach or interpret them. Luther especially assumed this stance soon after the German Peasants' War, which had clearly shown that society was not ready for laypeople to become teachers. All reformers were unanimous about women preachers contravening the teachings found in Paul's letters; women were supposed to be silent parishioners and obey their husbands. Laymen preachers were almost as suspect as women preachers. Preaching was only a part of clerical authority and masculinity, and in the matters of faith, laymen were also listeners.

The Reformations created more space for the public side of religion. Individuals, groups and political and religious parties tried to shape customs and institutions to better support their views and persuade or force others to join them. In the Middle Ages, overseeing people's religious life mainly concerned the clergy, but during the widespread disagreements of the Reformation era, it became everyone's concern. In various parts of Europe, this resulted in unrest, riots and even rebellion. Protestants destroyed pictures, paintings, statues, altars and even churches that Catholics held holy, and Catholics rioted just as violently 
in defending their sacred spaces and holy items. This often resulted in both camps destroying property belonging not only to the church but also to the broader populace.

In both Catholic and Protestant areas, laypeople also engaged in public displays of faith, especially in the early stages of religious change; they taught and preached. In the medieval church, laypeople - men and women alike - were explicitly banned from preaching. However, prophesying mystics could evade this ban by talking about their visions, as they came directly from God. Attitudes towards lay women's speech and words had been problematic ever since early Christianity, despite the public speaking of women being depicted approvingly in the Bible. It was a woman who delivered the most important message at Easter: Mary Magdalene had found the empty grave on Easter morning and informed the disciples. The disciples, however, deemed the apostola apostolorum's speech idle babble. This was a repeated tradition: the quiet Virgin Mary was considered the ideal woman, and idle talk, gossip and quarrelling were considered typical feminine vices. Mulier linguata, a woman who talked abundantly, idly and evilly, was the archetype of educational tales. Yet, in Mary Magdalene's legend, her message was found not only to be correct but also important. ${ }^{51}$

The church could take a favourable stance towards the public religious address of lay women on occasion. One such exception was the witnessing of a miracle in a church. A typical miraculous experience included pleading for help in a moment of distress and promising the heavenly intercessor a gift in return. After receiving the saint's help, a cure for example, the promised gift - a wax figure or torch, a candle, a piece of jewellery or an altar cloth among the wealthy - was offered to the saint. Giving a gift at the intercessor's shrine was part of the interaction and the petitioner's way of fulfilling his or her side of the pact.

The custodians guarding a saint's shrine interviewed pilgrims offering donations about their miraculous experiences. The most trustworthy stories were then written down in the records kept at the grave. Often, especially in the early stages of a cult, the miracles were also announced in church. Bells were tolled to call parishioners in to hear the announcement. Those who had experienced a miracle - be they men or women - could then stand up and share their religious experience with the clergy's approval and encouragement. After hearing the story, the parishioners praised God and the heavenly intercessor in question. It was rare for laypeople's words to warrant such attention in church, and these testimonies did not always run smoothly. Although laypeople had no right to teach in public, they certainly had opinions about church affairs and matters of faith. This meant that laypeople could deny a divine intercessor's powers or disagree with the religious practices and experiences of other parishioners.

Initially, the progress of the Reformations was considered more important than the ban on preaching. In many marriages, spouses represented different denominations, and so both Protestant and Catholic sides stressed that women had to stay silent in the parish when a man was spreading God's word, but they were allowed to speak after all the men were finished. Obeying God was naturally 
more important than obeying one's husband, but expressions were slightly unclear on purpose. At least clergymen representing the woman's denomination seemed to have thought that women should remain in their own faith and try to convert their nearest and dearest whenever possible. After the Protestant and Catholic Reformations had consolidated their positions, Protestant women's religious activities became more private again. Women were ideally only seen in public attending church, and even then, sitting in the pews quietly, listening to the sermon with their family. ${ }^{52}$

\section{Conclusions}

The boundaries between appropriate and inappropriate private and public spheres were also connected to the virtues and sins promoted by the church. Throughout Europe, secular courts supported the church in disseminating and enforcing these notions, and no single authority defined virtue and vice, honour and disgrace, or private and public. Honour and disgrace, like all the others, were closely linked to people's public roles in their community. Public opinion was important in defining public and private space and actions in fairly small medieval and early modern communities where all members knew each other. Honour and disgrace were important concepts in public opinion, which was constantly produced and lived out in the everyday life of people. Through public opinion, even those members of the community who remained in the home sphere could participate in the (mental) public sphere.

Although most women could not create legislation or execute regulations as officials, they had unofficial power. In pre-modern communities, public opinion regulated the lives of people just as much as laws, court rulings and religious teachings, and women were active agents in forming public opinion. They actively defined what was permitted and appropriate in the community, as well as what was not permitted and inappropriate. So, instead of being the objects of the restrictions dictated by common norms, women participated in producing these norms. Religion was both a platform and a medium for these processes of production giving meaning to the individual occurrences; in other words, turning them into culturally meaningful experiences.

The discussions about women's participation in the public sphere display a continuum. The dangers of women's public participation were already presented in medieval writings, and the definition of the public and private spheres and actions remained at the heart of religious teachings in the early modern period. The religious changes that took place in the early modern period due to the Protestant and Catholic Reformations are often considered to have confined women more closely to home. It is nevertheless wrong to think of the idea that women were only suited to the private sphere as an inevitable historical development that culminated in the enclosure of Victorian noblewomen. Despite the religious and societal changes, medieval and early modern religious writings shared a similar ideal of the gendered use of space, but practices nevertheless remained colourful and diverse. 
The differing and partly conflicting views of researchers are based on their use of different source materials, methods and starting points. Despite it being the ideal, few researchers claim that women were enclosed in their homes in the Middle Ages or the early modern period. Correspondingly, withdrawing into the not-so-private confines of one's home and eventually giving up household duties was a sign of a privileged position in a wealthy household, not of submission and oppression. In discussing women's public actions in medieval and early modern communities, we should bear in mind that the line between private and public as we understand it now was not created until in the bourgeois culture of the 19th century. In previous centuries, public and private had different definitions.

This chapter has further pondered the questions of accepted and disapproved or rejected experiences or faith and gender. One of them were pilgrimages which can be seen, in addition to a devotional act, also a method of appropriating a personal event. Rituals were a form of symbolic communication and important for social dynamics as pilgrimages were joint efforts. By embarking on a journey to a sacred space, people showed their gratitude but also manifested their position as a beneficiary of a miracle; they were social and spiritual performances at the same time. They were a way to give meaning to past event, to form it as an experience. Ritual participation enabled pilgrims to take the initiative and take charge of the interpretation of events: a suffering patient was turned, by God's grace, into a beneficiary of a miraculous recovery. This had wider than personal significance; simultaneously they manifested the power of God and the saints; the power of clerics, orders or monasteries housing the shrine; and finally they enabled the empowerment of a group of pilgrims or an individual. This empowerment might have been spiritual, when the Divine was experienced at the shrine. Within the social context, the pilgrims' path - the tribulations and subsequent recoveries reinforced the coherence of a community.

But just as approved experiences can create a community and give status in it, disapproved or rejected experiences can lead to persecution and hatred and, in some individuals, a quest for martyrdom as the final way of seeking legitimation in the eyes of God if not humans. The Radial pietist men described in this chapter, actively sought martyrdom and refused pardons that were offered to them on the condition that they recanted their beliefs and submitted their bodily and mental manhood to the authority of the traditional establishment. Seeking martyrdom and ascetism became an ultimate rebellion of corporeal and spiritual experience.

\section{Notes}

1 Pilgrims and pilgrimages have attracted a lot of scholarly attention. Pilgrimages have been categorised in several ways. According to the distance travelled, pilgrimages have been classified as long-distance (Fernpilgerfahrt), over-regional (Überregionale Pilgerfahrt), and local pilgrimages (Lokalen Wallfahrt). Schmugge, 'Die Anfänge des Organisierten Pilgerverkehrs', pp. 1-83, esp. p. 2. See also Caucci von Saucken, 'Le distanze nei pellegrinaggi medievali', 
pp. 297-315. They have also been categorised according to the motivation of the pilgrim as Bittpilgerfahrt to petition for a favour and Dankpilgerfahrt to give thanks for the grace gained. Krötzl, Pilger, Mirakel und Alltag, pp. 27-28. On categorisation according to the goal or motivation, see Sigal, 'Les différents types de pèlerinage', pp. 76-86.

2 Morrison, Women Pilgrims; Bowers, 'Margery Kempe as Traveler', pp. 1-28; Craigh, Wandering Women.

3 Il Processo per la Canonizzazione di S. Nicola da Tolentino, testis CXIII, pp. 308-310.

4 For more on this initiative and interaction, see Katajala-Peltomaa, Gender, Miracles, and Daily Life.

5 For gender roles in women's ascetic pilgrimages, see Katajala-Peltomaa, Gender, Miracles, and Daily Life, pp. 95-104.

6 Smoller, 'Miracle, Memory, and Meaning', pp. 429-454.

7 Katajala-Peltomaa, 'Devotional Strategies', pp. 21-45.

8 On political relations in the area, see Cecchi, 'Tolentino al tempo di San Nicola', pp. $129-157$.

9 On the practicalities of this hearing, see Gentili, 'Introduzione', IX-XXVII; San Nicola, Tolentino, le Marche; Lett, Un procès de canonisation.

10 On vendetta and other forms of reconciliation, see Jansen, Peace and Penance. On medieval prison, Geltner, The Medieval Prison.

11 Kuehn, 'Person and Gender in the Laws', p. 92.

12 Ashley and Sheingorn, Writing Faith, pp. 46, 113-115; Goodich, Violence and Miracle, pp. $48-57$.

13 In a canonisation process, articuli interrogatorii were formulated by the local proctor; they were a list of questions concerning the details of life and miracles of the candidate. In Clare's case there were 222 of them, both on the life and miracles of Clare.

14 Farmer, Surviving Poverty.

15 Il processo per la canonizzazione di Chiara da Montefalco, p. 512.

16 'Quod ipsa existens coniugata rapta fuerat per aliquos de magna sotietate. Super quo in tantum turbata fuit et etiam metu ne maritus suus propter haec ipsam odio iieret quod ipsa demens et demoniata fuit effecta'. BAV Vat. Lat. 4025, f. 124r. See also Levack, The Devil Within, p. 178 for a similar case of a servant girl becoming possessed after being raped, and Elliott, Proving Woman, p. 251 for a victim of incestuous rape. For a pregnant woman with vagationis errore, see the miracle collection of Laurence, Archbishop of Dublin. Bibliothéque Sainte-Geneviève, MS 1367 ff. 131r-131v. See also Actes anciens et documents concernant le Bienhereux Urban V Pape, pp. 67, 468.

17 See also Ferber, 'The Abuse of History', pp. 29-41 for possibilities and challenges in retrospective diagnosis; dissociative symptoms could have been provoked by sexual abuse and trauma and later turned into the language of the demonic.

18 On the evolution of the concept of demonic possession, see Caciola, Discerning Spirits; Sluhovsky, Believe Not Every Spirit; and Levack, The Devil Within.

19 Levack, The Devil Within, pp. 259-262. On public exorcisms as political manifestations of conflict between Catholics and Protestants, see Ferber, Demonic Possession; on Nicole Orby, pp. 68, 86.

20 Wiesner, Women and Gender, pp. 13-14. Also e.g. The English Book of Common Prayer from 1549, pp. 123-133 or Becon, The Catechism, pp. 459-465. In Finland, e.g. the home chart in Gezellius' catechism Yxi Lasten Paras Tawara from 1666, pp. 28-32.

21 Greco and Rose, Le Ménagier de Paris, on prayers and attire in public, esp. pp. 55-59.

22 Wiesner, Women and Gender, pp. 13-14.

23 Roper, The Holy Household.

24 Tague, 'Love, Honour and Obedience', pp. 76-106; Hartman, The Household, pp. 144ff; Dalarun, 'The Clerical Gaze', pp. 15-42.

25 Hanska, Strategies of Sanity, pp. 33-41, 68-77. On exempla of dancing, Etienne de Bourbon, Anecdotes historiques, p. 217 and Caesar of Heisterbach, Dialogus Miraculorum, IV, 11. On dancing, proper ritual practice, and demonic presence, see Katajala-Peltomaa, Demonic Possession and Lived Religion, pp. 151-155. 
26 Jääski 2-3 June 1686. Jääski, Ranta ja Äyräpää, II KO a:3: 227-229. NAF.

27 Ruokolahti 18-20 February 1689, Jääski, Ranta ja Äyräpää, II KO a:3: 183. NAF. See also Malmsted, 'In Defence of Holy Days', pp. 103-125; Kuha, Pyhäpäivien vietto.

28 E.g. Mänd, Pidustused keskaegse Liivimaa linnades; Kaljundi, 'Pagans into Peasants', pp. 357-392.

29 Talve, Suomen kansankulttuuri, pp. 251, 262-263.

30 Jääski 2-3 June 1686. Jääski, Ranta ja Äyräpää, II KO a:3: 227-229. NAF.

31 Jutikkala, Suomen talonpojan historia.

32 Haavio, Karjalan jumalat, pp. 19-20, 136-137; Nenonen, Noituus, taikuus ja noitavainot, pp. 69-72; Nenonen, 'Envious Are All the People', pp. 77-91. The same goes for the rest of Europe, see Katajala-Peltomaa, Gender, Miracles, and Daily Life, pp. 207-213.

33 On the secular representative nature of the household or village, see e.g. Eilola, Rajapinnoilla. On personal duties towards saints in personal matters like illness, see e.g. KatajalaPeltomaa, Gender, Miracles, and Daily Life.

34 Cf. Appel, 'Vaerdige Gaester', pp. 15-48.

35 Toivo, Witchcraft and Gender; Stark-Arola, Magic, Body and Social Order; Malmsted, Bondetro, pp. 159, 185.

36 E.g. Malmsted, Bondetro; Scribner, Popular Culture.

37 Scott, Reformation and Rural Society, p. 109.

38 Bossy, 'Counter-Reformation', pp. 51-70, esp. p. 62ff.

39 Shepard, Meanings of Manhood; Neal, The Masculine Self, pp. 57-71. On marriage and masculine identity, see Stuard, 'Burdens of Matrimony', pp. 61-71.

40 Lewis, 'Male Saints', pp. 112-133, quotation on p. 123.

41 Karras, 'Thomas Aquinas's Chastity Belt', and Karras, Sexuality in Medieval Europe, pp. 56-57.

42 Murray, 'One Flesh', pp. 34-51. As it promoted celibacy, the early Church was often strongly against marriage. The purpose of the nuptial images may have been to emphasise the proper gender order and women's subjugation. Wedding imagery may have been developed to counteract the idea that consecrated virgins were free from their gendered subordination; virgins were freed from sexual activity, which led, according to some arguments, to freedom from the constraints of their female bodies. Elliott, 'Tertullian', pp. 16-33.

43 Arnold, 'The Labour of Continence', pp. 102-118; Karras, 'Thomas Aquinas's Chastity Belt', pp. 52-67. See also Simons, Sex of Men, for virility as an element of manliness and social power.

44 On the origins of the concept of the vetula and its use in moral and vernacular treatises, see Mieszkowski, 'Old Age and Medieval Misogyny', pp. 299-319, and Pratt, 'De vetula', pp. 321-342. On old women in medical lore, see Jacquart and Thomasset, Sexuality and Medicine, pp. 75-76.

45 On Birgitta's image as a saint, He $\beta$, Heilige machen, pp. 201-204. On this case and the use of demonic presence in Birgitta's process, see Katajala-Peltomaa, Demonic Possession and Lived Religion, pp. 138-148.

46 On Vadstena Abbey's position and political relations, see Nyberg, Birgittinsk festgåva. On the brothers' preaching agenda, see Andersson and Borgehammar, 'The Preaching of the Birgittine Friars', pp. 209-236. In their sermons, the brothers were even constructing the supremacy of the ideal priest. On the political activity through their sermons, see Berglund, Guds stat och maktens villkor.

47 'Tunc aves rapaces preoccupaverunt cacumina moncium. Nam Theutunici tyrannizaverunt in terra multis annis'. Diarium Vadstenenese, p. 117.

48 Ruuth, Kansallinen elämäkerrasto: Lauri Ulstadius; Kansanaho, 'Suomalaiset yltiöpietistit', pp. 99-214; Kansallisbiografia: Lauri Ulstadius; Ullstadius, Lars to Turku Court of Appeal 22 July 1688: In Nomine Jesu. In Akiander (ed.), Historiska upplysningar, pp. 23-30.

49 Schäfer, Minä Pietar; Ylioppilasmatrikkeli: Peter Schäfer; see also Akiander (ed.), Historiska upplysningar, pp. 13-22, 30-53. 
50 Wallman, Der Pietismus; Laine, 'Sosiaalihistoriallinen näkökulma', pp. 405-420.

51 For the role and example of Mary Magdalene, see Jansen, Making of the Magdalen, pp. 265-270. For the sins of the tongue and their connections with femininity, see Casagrande and Vecchio, I peccati della lingua, pp. 407-417.

52 Lehmijoki-Gardner, Worldly Saints, pp. 146-165.

\section{Bibliography}

\section{Unprinted source material}

Bibliothéque Sainte-Geneviève, Paris: MS 1367.

The National Archives, Helsinki, Finland (NAF): Rural District Court Records: Jääski, Ranta ja Äyräpää.

Vatican Library, Rome (BAV): MS 4025.

\section{Printed source material}

Actes anciens et documents concernant le Bienhereux Urban V Pape, edited by Joseph M. H. Albanès and Ulysse Chevalier. Paris and Marseilles: Picard \& Ruat, 1897.

Akiander, Mathias (ed.). Historiska upplysningar om religiösa rörelserna i Finland. I. Helsinki: Suomen Historiallinen Seura, 1857.

Caesar of Heisterbach. Dialogus Miraculorum, edited by Joseph Strange. Ridgewood: The Gregg Press Inc., 1966 (1851).

The Catechism of Thomas Becon, S.T.P. with Other Pieces Written by Him in the Reign of King Edward the Sixth. Edited for the Parker Society. Cambridge: Cambridge University Press, 1844.

Diarium Vadstenenese. The Memorial Book of Vadstena Abbey. A Critical Edition with an Introduction, edited by Claes Gejrot. Stockholm: Almqvist \& Wiksell, 1988.

English Book of Common Prayer from 1549. In: The Two Liturgies, Set Forth in the Reign on King Edward VI. Griffits: Parker Society, 1844.

Etienne de Bourbon. Anecdotes historiques, légendes et apologues tirés du recueil inédit d'Etienne de Bourbon dominicain du 13e siècle, edited by A. Lecoy del a Marche. Paris: Librairie Renouard, 1877.

Gezelius, Johan (senior.). Lasten Paras Tawara. Turku: Peter Hannuksenpoika, 1666.

Il processo di canonizzazione di Chiara da Montefalco, edited by Enrico Menestò. Spoleto: Centro italiano di Studi sull'alto medioevo, 1991.

Il Processo per la Canonizzazione di S. Nicola da Tolentino, edited by Nicola Occhioni O. S. A. Rome: Padri Agotiniani di Tolentino and École française de Rome, 1984.

Schäfer, Peter. Minä Pietar ja Minä Anna: päiväkirja vuosilta 1707-1714, edited by Matti Piispa. Helsinki: Kustannusosakeyhtiö Otava, 2000.

\section{Literature}

Andersson, Roger, and Stephan Borgehammar. 'The Preaching of the Birgittine Friars at Vadstena Abbey (ca 1380-1515)'. Revue Mabillon 8, no. 69 (1997): 209-236. https:// doi.org/10.1484/J.RM.2.305583.

Appel, Charlotte. 'Vaerdige gaester ved herrens bord. Sognepraesternes rolle I administrationen af skriftemål og altergang efter reformationen'. In Religiös tro og praksis $i$ 
den dansk-norske helstat fra reformasjonen til opplysningstid ca. 1500-1814, edited by Arne Bugge Amundsen and Henning Laugerud, 15-48. Bergen: Universitetet i Bergen Institutt for lingvistiske, litterære og estetiske studier, 2010.

Arnold, John. 'The Labour of Continence: Masculinity and Clerical Virginity'. In Medieval Virgnities, edited by Anke Bernau, Ruth Evans, and Sarah Salih, 102-118. Toronto and Buffalo: University of Toronto Press, 2003.

Ashley, Kathleen, and Pamela Sheingorn. Writing Faith: Text, Sign, \& History in the Miracles of Saint Foy. Chicago and London: University of Chicago Press, 1999.

Berglund, Louise. Guds stat och maktens villkor. Politiska ideal $i$ Vadstena kloster, ca 13701470. Uppsala: Uppsala Universitets bibliotek, 2003.

Bossy, John. 'The Counter-Reformation and the People of Catholic Europe'. Past and Present 47, no. 1 (1970): 51-70. https://doi.org/10.1093/past/47.1.51.

Bowers, Terence. 'Margery Kempe as Traveler'. Studies in Philology 97, no. 1 (2000): 1-28.

Caciola, Nancy. Discerning Spirits: Divine and Demonic Possession in the Middle Ages. Ithaca: Cornell University Press, 2003.

Casagrande, Carla, and Silvana Vecchio. I peccati della lingua. Disciplina ed etica della parola nella cultura medievale. Rome: Instituto della Enciclopedia Italiana fondata da Giovanni Treccani, 1987.

Caucci von Saucken, Paolo. 'Le distanze nei pellegrinaggi medievali'. In Spazi, tempi, misure e percorsi nell'Europa del bassomedioevo, 297-315. Spoleto: Centro italiano di studi sull'alto medioevo, 1996.

Cecchi, Dante. 'Tolentino al tempo di San Nicola'. In San Nicola, Tolentino, le Marche. Contributi e ricerche sul Processo (a. 1325) per la Canonizzazione di San Nicola da Tolenino. Convegno internazionale di studi (Tolentino, 4-7 settembre 1985), 129-157. Tolentino: Tipolito A. Pezzotti, 1987.

Craigh, Leigh Ann. Wandering Women and Holy Matrons: Women as Pilgrims in the Later Middle Ages. Leiden: Brill, 2009.

Dalarun, Jacques. 'The Clerical Gaze'. In A History of Women, Vol. II: Silences of the Middle Ages, edited by Christiane Klapisch-Zuber, 15-42. Cambridge, MA: The Belknap Press of Harvard University Press, 1994 (1990).

Dixon, C. Scott, The Reformation and Rural Society: The Parishes of Branderburg-NasbachKulmbach 1528-1603. Cambridge: Cambridge University Press, 1996.

Eilola, Jari. Rajapinnoilla: Sallitun ja kielletyn määritteleminen 1600-luvun jälkipuoliskon noituus- ja taikuutapauksissa. Bibliotheca Historica 81. Helsinki: Finnish Literature Society, 2003. [On the Bordelines - Boundaries Between the Accepted and the Forbidden in Finnish and Swedish Witchcraft and Magic Cases in the Latter Half of the Seventeenth Century.]

Elliott, Dyan. Proving Woman: Female Spirituality and Inquisitional Culture in the Later Middle Ages. Princeton: Princeton University Press, 2004.

Elliott, Dyan. 'Tertullian, the Angelic Life, and the Bride of Christ'. In Gender and Christianity in Medieval Europe: New Perspectives, edited by Lisa M. Bitel and Felice Lifshitz, 16-33. Philadelphia: University of Pennsylvania Press, 2008.

Farmer, Sharon. Surviving Poverty in Medieval Paris: Gender, Ideology and the Daily Lives of the Poor. Ithaca: Cornell University Press, 2002.

Ferber, Sarah. Demonic Possession and Exorcism in Early Modern France. London: Routledge, 2004. Ferber, Sarah. 'The Abuse of History? Identity Politics, Disordered Identity and the "Really Real" in French Cases of Demonic Possession'. In Women, Identities and Communities in Early Modern Europe, edited by Stephanie Tarbin and Susan Broomhall, 29-41. Aldershot: Ashgate, 2008.

Geltner, Guy. The Medieval Prison: A Social History. Princeton: Princeton University Press, 2008. 
Gentili, Domenico. 'Introduzione'. In Il Processo per la Canonizzazione di S. Nicola da Tolentino, edited by Nicola Occhioni O. S. A. Padri Agotiniani di Tolentino, IXXXVII. Rome: École française de Rome, 1984.

Goodich, Michael. Violence and Miracle in the Fourteenth Century: Private Grief and Public Salvation. Chicago: University of Chicago Press, 1995.

Greco, Gina L., and Christine M. Rose (eds and trans.). The Good Wife's Guide: Le Ménagier de Paris. A Medieval Household Book. Ithaca: Cornell University Press, 2009.

Haavio, Martti. Karjalan jumalat. Uskontotieteellinen tutkimus. Helsinki: WSOY, 1959.

Hanska, Jussi. Strategies of Sanity and Survival: Religious Responses to Natural Disasters in the Middle Ages. Helsinki: Finnish Literature Society, 2002.

Hartman, Mary S. The Household and the Making of History: A Subversive View of the Western Past. Cambridge: Cambridge University Press, 2004.

$\mathrm{He} \beta$, Cordelia. Heilige machen im spätmittelalterlichen Ostseeraum. Die Kanonisationsprozesse von Birgitta von Schweden, Nikolaus von Linköping und Dorothea von Montau. Berlin: Akademie Verlag, 2008.

Jacquart, Danielle, and Claude Thomasset. Sexuality and Medicine in the Middle Ages. Princeton: Princeton University Press, 1988 (1985).

Jansen, Katherine Ludwig. The Making of the Magdalen: Preaching and Popular Devotion in the Later Middle Ages. Princeton: Princeton University Press, 2000.

Jansen, Katherine Ludwig. Peace and Penance in Late Medieval Italy. Princeton and Oxford: Princeton University Press, 2018.

Jutikkala, Eino. Suomen talonpojan historia. Helsinki: Finnish Literature Society, 1958.

Kaljundi, Linda. 'Pagans into Peasants: Ethnic and Social Boundaries in Early Modern Livonia'. In Re-forming Texts, Music and Church Art in the Early Modern North, edited by Tuomas M. S. Lehtonen and Linda Kaljundi, 357-392. Amsterdam: Amsterdam University Press, 2016.

Kansallisbiografia, The National Biography of Finland. Biographical Centre of the Finnish Literature Society. https://kansallisbiografia.fi/

Kansanaho, Erkki. 'Suomalaiset yltiöpietistit Lauri Ulstadius ja Pietari Schaefer'. Suomen Kirkkohistoriallisen Seuran Vuosikirja (1954): 99-214.

Karras, Ruth Mazo. Sexuality in Medieval Europe: Doing unto Others. New York: Routledge, 2005.

Karras, Ruth Mazo. 'Thomas Aquinas's Chastity Belt: Clerical Masculinity in Medieval Europe'. In Gender and Christianity in Medieval Europe: New Perspectives, edited by Lisa M. Bitel and Felice Lifshitz, 52-67. Philadelphia: University of Pennsylvania Press, 2008.

Katajala-Peltomaa, Sari. Gender, Miracles, and Daily Life: The Evidence of Fourteenth-Century Canonization Processes. Turnhout: Brepols, 2009.

Katajala-Peltomaa, Sari. 'Devotional Strategies in Everyday Life: Laity's Interaction with Saints in the North in the Fourteenth and Fifteenth Centuries'. In Lived Religion and the Long Reformation in Northern Europe c. 1300-1700, edited by Sari Katajala-Peltomaa and Raisa Maria Toivo, 21-45. Leiden: Brill, 2017.

Katajala-Peltomaa, Sari. Demonic Possession and Lived Religion in Later Medieval Europe. Oxford: Oxford University Press, 2020.

Krötzl, Christian. Pilger, Mirakel und Alltag. Formen des Verhaltens im skandinavischen Mittelalter (12.-15. Jahrhundert). Helsinki: Suomen historiallinen seura, 1994.

Kuehn, Thomas. 'Person and Gender in the Laws'. In Gender and Society in Renaissance Italy, edited by Judith C. Brown and Robert C. Davis, 87-107. London and New York: Longman, 1998. 
Kuha, Miia. Pyhäpäivien vietto varhaismodernin ajan Savossa (vuoteen 1710). Jyväskylä: Jyväskylän Yliopisto, 2016. [The Observance of Holy Days in Early Modern Savo (Eastern Finland)]. http://urn.fi/URN:ISBN:978-951-39-6598-3.

Laine, Esko M. 'Sosiaalihistoriallinen näkökulma pietismintutkimuksessa'. Teologinen aikakauskirja 5 (1992): 405-420.

Lehmijoki-Gardner, Maiju. Worldly Saints: Social Interaction of Dominican Penitent Women in Italy, 1200-1500. Helsinki: Suomen Historiallinen Seura, 1999.

Lett, Didier. Un procès de canonisation au Moyen Âge: Essai d'histoire sociale. Nicolas de Tolentino, 1325. Paris: Presses universitaires de France, 2008.

Levack, Brian. The Devil Within: Possession E Exorcism in the Christian West. New Haven: Yale University Press, 2013.

Lewis, Katherine J. 'Male Saints and Devotional Masculinity in Late Medieval England'. Gender and History 24, no. 1 (2012): 112-133.

Malmsted, Göran. Bondetro och kyrkoro. Religiös mentalitet i stormaktstidens Sverige. Lund: Nordic Academic Press, 2002.

Malmsted, Göran. 'In Defence of Holy Days: The Peasantry's Opposition to the Reduction of Holy Days in Early Modern Sweden'. Cultural history 3, no. 2 (2014): 103-125.

Mänd, Anu. Pidustused keskaegse Liivimaa linnades 1350-1550. Tallinn: Eesti Keele Sihtasutus, 2012.

Mieszkowski, Gretchen. 'Old Age and Medieval Misogyny: The Old Woman'. In Old Age in the Middle Ages and the Renaissance: Interdisciplinary Approaches to a Neglected Topic, edited by Albrecht Classen, 299-319. München: Walter de Gruyter, 2012.

Morrison, Susan Signe. Women Pilgrims in Late Medieval England: Private Piety as Public Performance. London: Routledge, 2000.

Murray, Jacqueline. 'One Flesh, Two Sexes, Three Genders?'. In Gender and Christianity in Medieval Europe: New Perspectives, edited by Lisa M. Bitel and Felice Lifshitz, 34-51. Philadelphia: University of Pennsylvania Press, 2008.

Neal, Derek G. The Masculine Self in Late Medieval England. Chicago: University of Chicago Press, 2008.

Nenonen, Marko. Noituus, taikuus ja noitavainot Ala-Satakunnan, Pohjois-Pohjanmaan ja Viipurin Karjalan maaseudulla 1620-1700. Helsinki: Finnish Literature Society, 1992.

Nenonen, Marko. “Envious Are All the People Witches Watch at Every Gate”: Finnish Witches and Witch Trials in the 17th Century'. Scandinavian Journal of History 18, no. 1 (1993): 77-91.

Nyberg, Tore (ed.). Birgittinsk festgåva: studier om Heliga Birgitta och Birgittinorden. Uppsala: Svenska kyrkohistoriska föreningen, 1991.

Pratt, Karen. 'De vetula: The Figure of the Old Woman in Medieval French Literature'. In Old Age in the Middle Ages and the Renaissance: Interdisciplinary Approaches to a Neglected Topic, edited by Albrecht Classen, 321-342. München: Walter de Gruyter, 2012.

Roper, Lyndal. The Holy Household: Women and Morals in Reformation Augsburg. Oxford: Clarendon Press, 1989.

Ruuth, Martti. 'Kansallinen elämäkerrasto V'. In Kansallinen Elämäkerrasto, edited by Kaarlo Blomstedt, Gabriel Rein, Martti Ruuth, Gunnar Suolahti, Väinö Voionmaa, Yrjö Karilas, and Ragnar Rosén. Porvoo: WSOY, 1927-1934.

San Nicola, Tolentino, le Marche. Contributi e ricerche sul Processo (a. 1325) per la Canonizzazione di San Nicola da Tolenino. Convegno internazionale di studi (Tolentino, 4-7 settembre 1985). Tolentino: Tipolito A. Pezzotti, 1987.

Schmugge, Ludwig. 'Die Anfänge des Organisierten Pilgerverkehrs'. Quellen und Forschungen aus italienischen Archiven und Bibliotheken 64 (1984): 1-83. 
Scribner, Robert. Popular Culture and Popular Movements in Reformation Germany. London: Routledge, 1987.

Shepard, Alexandra. Meanings of Manhood in Early Modern England. Oxford: Oxford University Press, 2003.

Sigal, Pierre André. 'Les différents types de pèlerinage'. In Wallfahrt kennt keine Grenzen, edited by Lenz Kriss-Rettenbeck and Gerda Möhler, 76-86. München: Schnell \& Steiner, 1984.

Simons, Patricia. The Sex of Men in Premodern Europe: A Cultural History. Cambridge: Cambridge University Press, 2011.

Sluhovsky, Moshe. Believe Not Every Spirit: Possession, Mysticism, E Discernment in Early Modern Catholicism. Chicago: University of Chicago Press, 2008.

Smoller, Laura Ackerman. 'Miracle, Memory, and Meaning in the Canonization of Vincent Ferrer, 1453-1454'. Speculum 73 (1998): 429-454.

Stark-Arola, Laura. Magic, Body and Social Order: The Construction of Gender Through Women's Private Rituals in Traditional Finland. Studia Fennica Folkloristica 5. Helsinki: Finnish Literature Society, 1998.

Stuard, Susan Mosher. 'Burdens of Matrimony: Husbanding and Gender in Medieval Italy'. In Medieval Masculinities: Regarding Men in the Middle Ages, edited by Clare A. Lees, 61-71. Minneapolis: University of Minnesota Press, 1994.

Tague, Ingrid H. 'Love, Honour and Obedience: Fashionable Women and the Discourse of Marriage in the Early Eighteenth Century'. Journal of British Studies 40, no. 1 (2001): 76-106. https://doi.org/10.1086/386235.

Talve, Ilmar. Suomen kansankulttuuri. Helsinki: Finnish Literature Society, 1990.

Toivo, Raisa Maria. Witchcraft and Gender in Early Modern society: Finland and the Wider European Experience. Aldershot: Ashgate, 2008.

Wallman, Johannes. Der Pietismus. Göttingen: Vandenhoeck und Ruprecht, 2005.

Wiesner, Merry E. Women and Gender in Early Modern Europe. Cambridge: Cambridge University Press, 2002 (1993).

Ylioppilasmatrikkeli 1640-1852 [List of University Students in Finland], edited by Yrjö Kotivuori. Digital edition in 2005. https://ylioppilasmatrikkeli.helsinki.fi. 


\section{3}

\section{SPIRITUALITY, SINFULNESS AND GENDER}

In clerical rhetoric, gender was a factor that actively steered (and restricted) what people could do and what skills and opportunities they could have. Sins were gender-specific, and the virtuous life meant different things for men and women. Attitudes towards various forms of religious exercises were also partly contradictory. Everybody was supposed to attend mass, but spending time in public places, even listening to a sermon in church, could lure women into temptation because of their weak morals; exchanging meaningful glances with men during public sermons could lead women into temptation. Attitudes towards pilgrimages show a similar contradiction. In principle, making a pilgrimage to a holy place was good for the salvation of the souls of both men and women, but for women, a pilgrimage meant leaving the home and the home sphere, home quarter or home village. In medieval literature, women as pilgrims are often depicted as having loose morals; travelling too far from home jeopardised a woman's reputation. Wandering the country did not fit with the public notion of a pious woman. ${ }^{1}$

The nature of piety only added to the confusion. Official religious ceremonies and forms of devotions were defined by men - priests, bishops, travelling preachers and confessors - and the church's internal hierarchy was also formed by men. Abbesses, prioresses and mother superiors of wealthy convents could hold considerable power, but women could not be ordained into the priesthood. Despite these gendered structures, the heart of religion was within the individual, beyond the reach of any external control. Furthermore, most devotions were unofficial; clergymen could not control the religious practices laypeople engaged in in their everyday lives, such as interacting with a saint, offering votive gifts or making pilgrimages. Many voluntary penances were also not directly controlled by the clergy. 
This chapter looks at recognised and contested means of spirituality and sinfulness, with sainthood and witchcraft and demonism as the extreme opposite ends of the continuum of gendered religious experience.

\section{Mother of God and other holy virgins: body and piety}

God's grace and power did not work solely through the church's official hierarchy and cult. God's gift of grace, charisma, for example the gift of tongues or prophecy, could fall on men and women alike. A person who received the God's gift was considered holy and could bend many rules, ranks and lines of action in church. Thanks to their virtuous lives, saints were closely in touch with God. The godly power of virtus acted through saints, and, after their death, through their relics. For her role in the incarnation, the Virgin Mary was especially close to the triune God. The Gospels actually speak very little of her; Proteuankelium Iacobi provides the foundation for her cult, and ecumenical councils defined her position. Mary was a virgin, but also the mother of God. She was completely unique and different from other women, but also bound by her femininity. ${ }^{2}$ Mary was also awarded many characteristics of a monarch. She was a hallowed and noble lady, domina nostra, and the queen of heaven, regina coeli, who also symbolised power. In a theological sense, Mary was seen as an intermediary, a redeemer of sinners, but her unique role in the incarnation made her a ruler of heaven and earth. Mary had a unique role in salvation and the redemption of sins, and was therefore perceived as the new Eve, the mother of all living things. ${ }^{3}$

The Marian cult underwent significant changes during the Middle Ages, and it varied from one place to another. There was no one uniform and constant idea of Mary. It is questionable whether Mary was supposed to be a role model for women in the first place, since she was elevated to a position others could not reach. However, her pain at the foot of the cross was used as an emblem within piety. Contemplating her suffering, often depicted as five swords piercing her heart, was crucial in affective meditation. She became an example and an encouragement to feel strongly. ${ }^{4}$

Mary's manifold power is emphasised by the previously cited Caesar of Heisterbach. His works include a story in which a priest lures a nun called Beatrice, a convent custos, into carnal sin with his tempting words. They flee the convent, but the priest soon abandons his lover, and Beatrice does not dare return to her convent. She has no other income, so for years, she makes a living as a prostitute. In the end, Beatrice decides to return to the convent, beg for her sins to be forgiven and hope to be accepted back. When Beatrice is about to step into the convent's church, she has a vision of the Virgin Mary telling her not to tell anyone of her error; all these years, Mary had appeared in the sinful nun's place at the convent, leaving everyone in the abbey none the wiser about Beatrice's sins. ${ }^{5}$

It was understandable that nuns and monks who adopted a cloistered life young and sometimes against their will could regret the decision and change their mind, but that is not the point of Beatrice's story. The moral of her story 
becomes clearer when we learn that in her time at the convent, Beatrice was a dedicated devotee of the Virgin Mary. Mary's miracles typically portray her as very compassionate and merciful towards sinners if they were devoted to her. Mary was less compassionate towards the less devoted and took vengeance for any supercilious words and insults against her. Beatrice's case is an extreme example of what mutual loyalty could produce. Marian miracles often focus on dedicated Christians who were rewarded: Mary did not abandon her own. Mary was like a feudal ruler, the Queen of Heaven, but not only that, many stories emphasised her motherhood. Mary could be like a mother to sinners, gentle and merciful.

Caesar also highlights this aspect. He recounts a tale of a simple lay brother who prayed to Christ to help him resist temptation. To his prayer, he added a threat: he would let Christ's mother know if his plea was not answered. ${ }^{6}$ The stories that portrayed Mary as a mother may have presented to listeners a familiar story of a gentle and loving mother who guided her son. These stories thus testified to the value of motherhood in general, although women could not be compared to Mary as individuals.

Mary was not the only woman considered a saint by the medieval church. The Late Middle Ages in particular saw a growth in the number of saints overall, but also in the number of women saints. This has been explained by people taking a new approach to saints. Biblical and historical role models were no longer enough for Christians; to dedicate themselves to a saint, they required a personal commitment and an emotional bond with their heavenly intercessor. This bond was easier to form with a person who was either geographically or temporally close. Another explanation for the popularity of new saints is that these new intermediaries needed a group of supporters to establish their place in the divine hierarchy. Because they were eager to gain supporters, new saints were thought to be keen to listen to the believers' worries and quick to respond to their pleas for help. ${ }^{7}$

People in need of help could also take advantage of the fact that new saints needed publicity. Ceccholus, for example, promised to share news of the powers of Saint Clare of Montefalco with one hundred people if she cured his toothache. ${ }^{8}$ This promise was recorded in Clare's canonisation process, during which papal commissaries interviewed people about the miracles Clare had performed and the virtuousness of her life. These interviews were naturally conducted before the canonisation, the official declaration of sainthood, and it can be thought that Clare needed to gain devotees and loyal supporters at the time of Ceccholus' toothache to strengthen her cult and give it official status. Apparently, this was a successful exchange: Ceccholus was cured, the story of Clare's sanctity was spread and eventually she gained official papal recognition of her sainthood.

Although the church recognised Saint Clare of Montefalco as a saint, she was not compared to the Virgin Mary. Clare and other female saints were gendered differently from Mary: physical motherhood or motherliness were not central to their sainthood. Saintly women were characterised especially by virginity, severe asceticism and often also mystical visions; they fasted and mortified their flesh 
in various ways. Women's vitae did not highlight female corporality, such as motherhood, although some saints did nurse the infant Christ in their mystical experiences. The predominant trend was the rejection of sexuality, while corporality played an important role in their devotion. ${ }^{9}$

Bodily integrity was crucial in women's chastity already in Late Antiquity; the newly emerging idea of perpetual virginity changed not only the individuals' lives but also society and culture as a whole. The public cults of the traditional polytheistic religion of Ancient Rome demanded the participation of all members of society. From a gender perspective, many of the cults were based on a complementary gender model: the active performance of both men and women was required and tasks were clearly defined, even if these tasks could have subverted what was generally expected of men and women. ${ }^{10}$ Christianity brought with it a more profound need for the queering of the gender system. Firstly, it introduced the rank of 'laity' as opposed to those who were professional experts in religion. Typically, in polytheistic religion, the position of the priest was temporal and it did not exclude ordinary societal functions. Just as profound a change was celibacy as a life choice, which Christianity launched. This meant turning upside down traditional values and social expectations also for men. Being a pater familias crystallised patriarchal power - and celibate religious men renounced this opportunity voluntarily. During the Middle Ages, celibacy was a well-established and esteemed position, yet it was not unproblematic.

Virginity did not mean only physical chastity, but also mental purity; thoughts and actions did not differ much from one another. Chastity equalled freedom from sin, so people were no closer to salvation if they replaced one pleasure with another. Spiritual chastity was more important than its bodily analogue: virginity could be lost only by thinking about sex. By the strictest definitions, only people who had never wanted sex or been desired by another person could be virgins. This was because the lust women aroused in others was considered to be their fault. Early Christian authors thus concluded that only a woman who had never been seen by a man could be a virgin, because the moment a man saw a virgin, there was a possibility he desired her. This logic was taken so far that virginity almost became a synonym for martyrdom. These definitions of virginity were therefore almost impossible to meet. ${ }^{11}$

Virginity was a complex matter indeed, since it required chastity and bodily integrity, but physical purity in itself was insufficient since it did not ensure virtue. Most medieval female saints were virgins, although some women who were or had been married and had children were also considered to be saints in the Late Middle Ages. Virginity and chastity were not identical, and chastity was also a hierarchical construction: the moralists insisted that it was the church's responsibility to recognise it and its constituent elements. ${ }^{12} \mathrm{~A}$ chaste person could be a virgin mentally, although she was not a virgin physically. ${ }^{13}$ Therefore, virginity as a constituent of chastity was in need of re-construction and manifestation. ${ }^{14}$

The deposition in the canonisation process of Clare of Montefalco leads us to assume that Clare was aware of such chastity requirements. For example, she 
hung a veil between herself and the person who came to talk to her in the convent because she did not want people to see her through her chamber window. Clare did this even with her own brother. ${ }^{15}$ According to her convent sister's statement, Clare went so far as to declare that she would rather spend the rest of her earthly life in hell than lose her virginity, and that she would rather endure hellish physical mutilation than be (mentally) separated from God. ${ }^{16}$

Abhorrence of the flesh - as opposed to the spirit - is visible in the patristic writings; early Christian authors often linked corporality with carnality and sinful lust. Carnality was the main cause of sinfulness, as temptation arose from the flesh. ${ }^{17}$ However, medieval approaches to the body were not simple or straightforward. They proposed a dualistic model: the body was a psychosomatic unity and potential site for redemption, but the flesh encompassed carnal desires. Bodies could be utilised as tools for the practice of penitence, abstinence and asceticism. The body enabled encounters with both God and the Devil; it could be the means to both salvation and damnation. ${ }^{18}$ Both sides are visible, for example, in the narration from Saint Birgitta's youth when she was around thirteen years of age. As Birgitta was married off young, her mother-in-law played an important part in raising her. One night she found Birgitta out of bed naked, crying on her knees. Suspecting something illegitimate was going on, she took a whip to educate the girl. However, when it hit Birgitta's back, it crumbled into small pieces. She was both astonished and alarmed, and asked if Birgitta had uttered fallacious prayers. Birgitta denied doing so and explained that she only got out of bed to pray to the one who was always quick to help her - Christ on the crucifix before her eyes, she explained further. This tale was told to the lay audience on Birgitta's feast day. ${ }^{19}$ Obviously, its main goal was to promote the sanctity of Birgitta, but simultaneously it informed the audience of the many positions the body held within religion. The naked female body was a clear indicator of sexual lust, something to be wary of even by women themselves, as is clear in the mother-inlaw's reaction. At the same time, within religious practices, the body could be a manifestation of the utmost humility and, in Birgitta's case, piety. In either way, body was the site where religion was experienced and the body affected the way religion was comprehended, felt and practised.

Saints aimed to mortify their carnality, but the body was also an important tool and means of religious expression. Controlling bodily functions, movement and gestures was a way to express one's devotion. This could mean maintaining one's virginity, strict fasting, wearing a hair shirt and other penitential garments or appurtenances, flagellating oneself or following a strict clausura. Bodily punishment was, however, not an externally dictated necessity: women could refuse it or use it to control their bodies. For them, it was a freedom of expression and a way of creating a private space. ${ }^{20}$ According to sisters at the Augustinian convent of Montefalco, Clare kept a very strict fast. She ate only one meal a day, and even that was often just water and bread. Sometimes she would eat vegetables and herbs, but no bread. The sisters wondered how anyone could survive on such a paltry amount of food and eventually encouraged Clare to give up such strict 
asceticism because it would prevent her from serving God devoutly and lead to a premature death. Clare was not willing to give up fasting, but she did adopt a less strict ascetic practice upon doctor's orders - in addition to her other virtues, Clare was also humble and obedient. ${ }^{21}$

Clare fell gravely ill in later life and was in ailing health in her final years. She is said to have been patient and humble regarding her physical condition, which may have been God's way of trying her or a result of her severe asceticism. Patience before worldly trials was a virtue, because it showed that one submitted to God's will. Illnesses thus offered an opportunity for spiritual growth because they enabled communication with God. ${ }^{22}$ Illness was, thus, one form of her sanctity, since suffering was an essential element in the connection with Christ's body. This was clearly an admirable element in her life, but not necessarily something to be imitated. Like many other saints, Clare took ideals and customs to extremes; such severe asceticism hardly served as a model for ordinary Christians. $^{23}$

Those other people considered to be saints - and who considered themselves saints - may consciously have learned and taken their cues from the vitae of earlier saints. Biographers may have described the life of a saintly protagonist in a way that fitted into earlier models and made the lives of contemporary saints more understandable to common Christians. ${ }^{24}$ Biographers may have played a particularly significant role in the lives of such women, both in terms of narration and experience, because few holy women wrote down their experiences in the Middle Ages. For this reason, some features typically attributed to the lives of women saints may be questioned. It seems that especially in the High Middle Ages, women themselves did not yet focus on asceticism when they wrote about their lives and practices. At least some of the stereotypes of holy women, such as strict fasts, seem in fact to be features highlighted by biographers and not things women themselves considered vital in their lives. ${ }^{25}$ Previous literary models influenced not only the narratives but also the way people perceived their own experiences.

The relationship between women saints and their confessors reflect the gender expectations and hierarchies in many ways. Dyan Elliott, for example, links this kind of relationship with marriage, owing to its intimacy and heterosexual hierarchy. Women in general were considered to be more prone to supernatural influences, be they bad or good. This meant they were seen as ample vessels to attain God's charisma and have mystical experiences, but they needed masculine authority to back up their experiences. Without a supporter - a confessor or cleric - to encourage such women and validate their words and visions, women mystics were vulnerable to accusations of delusion, possession, heresy and, at a later date, witchcraft. ${ }^{26}$

The mystical experiences of Saint Clare of Montefalco also connect her to other women saints of the time. Like many other medieval saints, Clare achieved direct contact with God and gained empirical knowledge of Him through her mystical experiences, visions and revelations. Christ-mysticism was an essential 
part of the lives of many medieval women saints, and many of its descriptions are, at least to modern readers, surprisingly close to descriptions of physical love. Nevertheless, Clare's mystical experiences differed from many of those of her contemporaries. Unlike Angela of Foligno, Clare of Montefalco did not experience the physical presence of Christ, drink from the Christ's wounds or lie with him in his grave exchanging kisses after he had been taken down from the cross. The convent sisters who reported Clare's experiences also did not mention a mystical engagement with Christ or Clare wearing an invisible engagement ring like Catherine of Siena. Regardless, as Clare was a nun, the medieval community viewed her as a bride of Christ. ${ }^{27}$

Nuptial images in the lives of women ascetics emerged already in Late Antiquity. By the end of the Middle Ages, the set of rituals connected to a girl's path to becoming a nun closely resembled actual wedding ceremonies. Both taking the veil and marrying can be considered related versions of the same act: there was a change of social status and the celebration of giving a woman to a man. ${ }^{28}$ The same ideas were also reflected in the mystical literature; the idea of a nun or a mystic as a sponsa Christi and especially the mystical marriage to Christ emerged in the later Middle Ages, first in northern Europe among the Beguines of the Low Countries and then, in the 14th century, in the hagiography of Italian penitents. Sarah McNamer even argues that the consecration rituals not only mimicked wedding ceremonies; they actually signified the making of a marriage contract with legal efficacy. The nuns were actually married to Christ, even if their marriage could not be consummated in this world but had to wait until the hereafter. McNamer sees this as the major incentive for gendered devotional practices; religious women had a greater incentive to cultivate compassion for the suffering of Christ, since part of proving marital fidelity was showing maritalis affectio. Men could not enter into legal marriage with Christ, and they were not expected to participate in the suffering in such an affective way. However, pain on account of Christ's suffering could prove that the virgin or nun was worthy of the marriage and its rewards in heaven. ${ }^{29}$

Compassion for the suffering Christ was essentially a feminine emotion and a crucial element of affective piety, which was a major trend in late medieval religiosity. The rhetoric of affectivity emerged first in the writings of the Cistercians in the 12th century and then spread to other orders and the laity. It was an evident element in all literary genres from the 13 th century onward. ${ }^{30}$ The use of emotions was encouraged in devotional literature; the intention was to create a personal relationship with Christ and other holy persons. Contemplating Christ's passion and the Virgin Mary's grief at the loss of her son were particularly important elements of this form of religiosity. ${ }^{31}$ The increased focus on religious emotiveness was associated with the feminisation of religious language and with feminine virtues, such as humility and weakness. It promoted an increased emphasis on humility and a tendency towards lachrymose prayer among the faithful, not just women. Furthermore, affective elements should not only be seen as an expression of gentler, supposedly feminine virtues, since affective 
religion also encompassed rage, ferocity, pride and intolerance. ${ }^{32}$ Production of emotions was part of power relations; they were a tool for control but also a method of empowerment shaping understanding of both gender and religion.

Although Clare's experiences differed from those of other women saints, she also had a clear physical connection to Christ. On some occasions, Clare claimed that she had Jesus Christ in her heart. For example, when she refused to accept the sign of the cross, she said: 'What are you doing? I do not need the sign of the cross, for I have the crucifix, Jesus Christ, in my heart'. At first, her contemporaries, other convent sisters and confessors all took Clare's words to be figurative and a sign of her mystical experiences and identification with Christ's suffering. However, Clare was so determined and persistent in her words that in the end, she convinced especially the sisters at the convent to take her words literally. The sisters were able to convince local clergymen and doctors, and so immediately after Clare died, they performed an autopsy on her body and indeed found a crucifix and other signs of penance in her heart.

In the end, Clare's virtuous life with its strict fasts, the miracles she performed both during and after her life, and the miraculous artefacts in her heart finally convinced the papal curia: Clare was declared a saint and venerated by the entire Catholic Church, but not until 1881. Although in addition to the sisters at Clare's convent, several hundred laypeople and clergymen witnessed the miracles she had performed and her gift of grace in the canonisation process in 1318-1319, contemporaries were divided over Clare and other women considered to be holy. Some believed in their holiness, but some were averse to the severe spiritual strivings, fasts, penances, and mystical visions and experiences.

An early modern example of the union of the bodily and the spiritual is Saint Teresa of Ávila, also called Saint Teresa of Jesus (1515-1582). She came from a converso family in Spain, and had become a nun after her mother died in 1529. She became one of the great mystics and religious women of the Roman Catholic Church and the leader of the Carmelite Reform, which restored and emphasised the austerity and contemplative character of primitive Carmelite life. During the emphasis on religious renewal in the Council of Trent, Teresa thought that the Carmelite Order should return to its original observance of austerity, which had been relaxed in the 14th and 15th centuries. Austerity was a feature of Tridentine Catholicism in general, but it has been suggested that although Teresa never alluded to her background, the common prejudice against Jews and conversos as being extravagant and ostentatious may have prompted in her a reaction in the other extreme. ${ }^{33}$ She required utter withdrawal so that the nuns could meditate on divine law and, through a prayerful life of penance, exercise what she termed 'our vocation of reparation' for the sins of humankind. Reception was utterly divided: with Pope Pius IV's authorisation, she opened the first convent (St Joseph's) of the Carmelite Reform in 1562. At the same time, both religious and local lay authorities were suspicious and hostile, especially because the convent existed without endowment. Nevertheless, seventeen convents throughout Spain were established under the restored Primitive Rule, 
known as the Discalced (or 'Unshod') Carmelites. Further hostilities emerged between the Restored and the Mitigated convents, meaning Teresa alternated between disfavour and exile and favour and mission work.

The legend emphasises how, despite her continuously failing health, Teresa travelled thousands of miles and managed to organise numerous communities and spread the reform. Teresa's legend and depictions - like the classical Ecstasy of Teresa by Gianlorenzo Bernini in 1651, with it explicitly sexual symbolism utilised her ill health and frail body by emphasising them in a mystical union with Jesus and God. Her bodily suffering and spiritual ecstasy are contrasted in her own writings, where she uses the vocabulary of marriage, fire and purification both from Jewish and Islamic writings but also - as a matter of course - from Tridentine Catholic writings to express her spiritual and bodily love of God. Though the Reformations - the Protestant as well as Catholic - emphasised the rational and the inner, they in no way left out the body or the gendered nature of the experience. ${ }^{34}$

\section{The lay Marys: women religious}

Defining gender and gender roles and then queering them is of crucial importance for any power structure, and Christianity was no exception. Disputes over gender were inherent in pre-modern Christianity. Debates about masculinity and especially femininity were active already in Late Antiquity; they were going on with various intensities all through the Middle Ages and grew more heated during the Renaissance. The Reformation probably did not immediately change the role of women in society or religion, but reformers did summarise the prevailing ideas of women and the place of women in society in their writings and words. Although the Bible includes examples of prophesying and preaching women (e.g. Hannah, Anna and Mary Magdalene), they seem to be missing during the reformers' time - not that reformers tried to find them. Even Luther's Käthe, despite her important role in running the household, had to keep away from the men's dinner table and quietly listen to her husband and his comrades preach and joke over dinner. ${ }^{35}$

The model of humility and obedience for Protestants continued to be Virgin Mary: she accepted the fate the angel announced to her with no questions asked, agreed to give birth to Jesus and then let her baby accept his destiny. Mary was used as an example of humility especially for young women, for Mary herself had been a young unmarried woman when the angel appeared to her. In the surviving visitation sermons of bishops, Mary is portrayed not only as a devout and humble believer but also as a young girl who was eager to serve her family and relatives and content to stay in the confines of her home. ${ }^{36}$

Reformation-period theology should be viewed as a debate about both dogmatic and social questions. Researchers who focus on Protestants criticise Luther of his unenlightened views on women, but the same criticism can be applied to the Catholic Church in the Late Middle Ages and Renaissance. Although 
convents acted as meeting places for politicians and as hubs of information, thus offering some women considerable political power, convent life was possible only for the richest women who were supported by their family. Others had to make do with a secular life. If Luther's notion of motherhood created a restricting, one-sided role for women, the Catholic Church hardly offered many feminine role models that could be emulated.

Like the Protestant Reformations, the Catholic Reformation initiated a major change in the position of women. Printing houses began to disseminate the writings and biographies of mystics, such as Teresa of Avila, that could be accessed by women in the highest strata of society. In the early 17th century, a Carmelite order spread to France and established fifty-five convents in four decades. These convents became centres of the new Catholic religion, but Carmelite nuns also aimed to influence the surrounding society. Although the clergy - in other words, men - strongly controlled the church, these women became the advisers and confidantes of several important political leaders. The early stages of the Catholic Reformation were also strongly characterised by feminine mystics. Many of the early communities gathered around individual charismatic characters, and these communities had a great impact on their environment. ${ }^{37}$

The Catholic Reformation also included a large-scale attempt to educate the masses. Popular education was part of the Catholic Church's attempt to convert people back from Protestantism, which itself claimed to attract believers through popular education, reproaching its Catholic competition for ignorance and a lack of education. These rebukes were largely propaganda; the Protestants' own popular education was not very progressive at first, but counterpropaganda required the Catholics to offer popular education, as did the new forms of Catholic faith that began to emerge little by little after the Council of Trent (1545-1563).

The Catholic Reformation's needs gave birth to new religious orders, such as the Society of Jesus, the Discalced Carmelites and the Ursulines. The particular focus of the Society of Jesus was on missionary work and educating the clergy, and the schools founded by Jesuits drew in higher-level students. By contrast, the focus of the two secular orders for women established in the 17th century was on popular education. Devotées almost stormed in to teach the catechism.

In the early stages, devotees mostly aimed to apply Christian values to all aspects of their life as visibly as possible: in their marriage, family life, parenting, education and pilgrimages. They wanted to gain God's favour for themselves and their entire community by serving Him impressively and by acting as an example to others. Chastity was a virtue above all others especially for women, but an extravagance of faith and leading by example were also of great value. Loyal devotees would therefore kneel at the church doorstep in the morning and wait for the church to open its doors. Later, when the Company of the Most Blessed Sacrament was falling out of favour, third- and fourth-generation devotees took up Jansenism.

Although the Catholic Church was not very keen on women's orders at first and efficiently ushered the reformed Ursulines back into enclosed convents, women's 
orders spread. The rapidly changing society called for counter-reformative catechism education, but despite a clear social need, women's work 'in the midst of people' faced strict resistance. A similar phenomenon had been noted in the Late Middle Ages with lay Penitents. They were religious women living 'in the world', but living a life of prayer, abstinence and charity. They had taken a vow of chastity and did not fit into the conventional models set out for women. Their way of living caused confusion, fear and resistance both in the church and among laypeople. Attitudes towards Penitents grew stricter in the Late Middle Ages when they were more closely enclosed in cloisters. ${ }^{38}$

The mid-17th century saw women surging into the arms of the Catholic Reformation. Europe was just coming out of its religious wars, and women felt the need for a social reform. Lay religious movements now had to admit that they could not keep calling their members nuns (who were, by definition, confined with the convent walls) while at the same time keep operating outside convents. Devotee groups stopped calling themselves religious orders, although they continued in this tradition. The main duties of devotees became running girls' schools, nursing in community hospitals, and teaching the catechism.

As the post-Reformation developments demonstrate, the wants and needs of women for a public religious life did not disappear. Most devotee movements in the early 17 th century withdrew to enclosed convents under pressure, but women continued to teach in the convents. Nuns had previously been allowed to only teach in closed communities; in practice, they could only teach girls who lived in the convents. The pope allowed the first day-school taught by a woman in 1607, with women teaching girls only. Allowing young men into a convent community would have posed too great a danger to the nuns' chastity. It is also possible that parents would more readily allow girls to attend all-girl schools. Girls had never before been systematically educated on such a large scale, so these schools had a considerable social significance. As the schools for young girls established their place, women's seminaries and communities started springing up to meet the needs of the next generations of students. ${ }^{39}$

Protestant areas saw the birth of similar movements in the late 17 th century. They demanded penance of the world and aimed to reform ecclesiastical and individual religious life, thereby forcing lay men and - more strikingly - lay women into action. These movements were called pietistic movements; they challenged Protestant orthodoxy and typically centred around a young, radical clergy. Pietism originated in the work Pia desideria, or Earnest Desire for a Reform of the True Evangelical Church, published by pastor Philipp Jacob Spener in Frankfurt in 1675. Pietistic thoughts reached Finland thirteen years later when aforementioned Laurentius Ulstadius - the young son of a priest - interrupted a sermon and began to demand improvements from the parish and the clergy. At the time, new thoughts spread through networks: Pietist groups were scattered sparsely around Europe, but interested parties typically travelled to visit other groups. ${ }^{40}$

Women had an important role especially in maintaining these networks. The 18th century witnessed a change in the nature of Pietism: in Finland, too, 
Pietism transformed into a fanatical anticipation of the end of the world. The Finnish revival originated in Kalanti in 1756, and it was characteristically led by women until the early 19th century. Like Liisa Eerikintytär, who was the first to experience ecstasy, these preachers were peasants, burghers or maids, not noblewomen. In France, the Daughters of Charity gathered together bourgeois women in the 17th century, but in Sweden, ordinary women only formed their own religious communities a century later. Just like the devotee groups, leaders of Ecstatic Pietism were also men; in Finland, the Pietist movement was headed by Abraham Achrenius, the vicar of Nousiainen. ${ }^{41}$

It remains unresolved whether women's religious movements during the Catholic Reformation and Protestant Pietism were the result of social pressure or whether the abundant supply of active women caused the demand for education and nursing. This is relevant in determining how active women were: did the needs and initiative of women launch the change, or did women merely respond and react to an external need? In reality, it is also possible that the needs of women and society aligned neatly.

Although both Catholic and Protestant leaders wanted their Reformations to be controlled and centrally led, neither side succeeded in this. The objectives and methods of the Reformations both united and separated each denomination. The church did not want to suppress women's religious activities - it only wanted more control over them. In Protestant countries, women's duties involved educating their children and their servants, but this had to be done at home. In Catholic countries, catechisms and codes of conduct involved similar teachings, but their results were somewhat different. ${ }^{42}$

\section{Vade diabolo - go to the Devil!}

Some people thought that rather than being holy, women ascetics and prophets were, if not evil, at least deluded or possessed by the Devil. According to the pre-modern worldview, both God and the Devil operated actively in the world. The Devil lured people into sin, but he could also penetrate bodily boundaries by force and possess an innocent person. Medieval stories demonstrate a wide spectrum of how this could take place. ${ }^{43}$ For example, the Devil possessed a wife when her irritable husband snapped 'Vade diabolo - Go to the Devil!' at her. ${ }^{44}$ The majority of medieval victims were considered to be innocent, since the Devil or demons could only possess people's bodies, while their souls remained unharmed. Furthermore, they were not guilty of any actions caused by the malign spirits. For some, however, possession was a punishment for their misdemeanours, such as in the case of Hans Smek, whom we met in the previous chapter. The idea of possession had changed by the turn of the early modern era. Demoniacs were at that time more readily seen as willingly having submitted to the Devil or else as victims of another person's malediction. ${ }^{45}$

Signs of possession included, for example, speaking in languages, prophesying, screaming and violently tearing at one's hair or clothes. Some of the mystical 
experiences of saints were described in a very similar way. According to the church, demons were fallen angels and thus belonged to the spiritual realm. They therefore had in-depth information about matters of faith - information Christians did not have. Since a woman possessed by the Devil was not in control of her body, she did not violate the church's teachings in making prophecies; the Devil spoke through her. It was no wonder that contemporaries could be confused over the similar expression of possession and sainthood. According to Barbara Newman, possession could have been knowingly used by women to gain respect and wider opportunities in the field of religion. Nancy Caciola, on the other hand, argues that these women considered themselves to be possessed by the spirit of God. Demonic possession was an interpretation made by the community, which saw the religious practices of these women in a negative light. ${ }^{46}$ The women considered themselves inspired by and occupied by the divine spirit, but they were increasingly suspected of being possessed by malign spirits. As phenomena, mysticism and demonic possession were not close: they were opposites and infinitely far apart, although they could be manifested in bewilderingly similar ways. Demonic possession was partly a gendered phenomenon: the majority of the victims were women, but adult men could also be found among the demoniacs. ${ }^{47}$

As far as we know, Clare of Montefalco was never suspected of possession during her lifetime. This may have been because her strict asceticism and her mystical experiences took place within the confines of a convent, and the convent community responded to them with understanding and respect rather than suspicion. Even Clare did not enjoy unconditional admiration and veneration, however - she was suspected of heresy. ${ }^{48}$ In northern Italy at the time, the Heresy of the so-called Free Spirit was fairly common, it was very loosely grouped movement that criticised the church's role and importance in salvation. Clare was accused of being part of this group or at least collaborating too closely with its members. She had apparently interacted with brother Bentivenga da Gubbio, a Free Spirit follower convicted of heresy in 1307. The nuns at Clare's convent and Clare's brother - the Fransiscan Francischus Damiani - who gave statements in Clare's canonisation process point out that she had had heated discussions with followers of the Free Spirit and objected to their thinking. According to the same statements, Clare had actively helped catch these heretics and convict them of their errors. The sisters claim that the interaction was merely a bother, inconvenience and threat to Clare. Franciscan brother Thomas Boni de Fulgineo interprets this interaction in another way. According to him, Clare was on friendly terms with the aforementioned Bentivenga, various Free Spirit heretics and other people of ill repute. Thomas Boni de Fulgineo founds his claim on his own experience as the chaplain of the Montefalco cloister. ${ }^{49}$

As phenomena, demonic possession, heresy and witchcraft were all linked within the discussions of the Christian cosmography of evil. There can be seen a temporal change in the church's focus, but the chronological evolution of these phenomena is not straightforwardly linear. In the 13th and 14th centuries, the 
Catholic Church was concerned with various heretical groups. In turn, witchcraft and magic became burning issues for the church in the 15th century, giving birth to demonology and the witch craze. Cases of demonic possession can be found already in the Bible, and cases were recorded throughout the Middle Ages. However, it is the early modern era that is characterised as 'the Golden Age of the Demoniac' ${ }^{50}$

Religious participation during the Middle Ages and early modern era was both individual and communal; inner spirituality was a prerequisite, but religion was practised together. Religious practices were also a means to create togetherness on a familial, communal or patriotic/national level. The comprehension of 'us' could also mean the construction of privileged sub-groups. A regular part of processes creating communality and collective identity is its counterpart: alterity. Since identity-building is a fluid process characterised by boundary maintenance, the construction of 'the Other' was often part of defining 'us' within religion-as-lived. As Christian thought also heavily built on binary oppositions of good and evil, saints and sinners, forbidden and prescribed, demonisation of the enemy was a rhetorical practice from early Christianity on. During the Middle Ages, various groups deemed as heretical were seen as the main opponent by the church. In anti-heretical polemics, 'heretical depravity' - deviation from the truth of the church and a contestation of its position or papal prerogatives - was considered to be the work of the Devil. Leaders of these groups were seen as the Antichrist. Conversely, a similar rhetoric was used among these groups against Catholics, and especially against inquisitors and the pope. ${ }^{51}$

The demonisation of the world at the beginning of the early modern era was no doubt one result of the Reformations, the fragmentation of the universal church, disputes over proper rites, and contradictory opinions on what was sacred. The prevalence of the diabolical in early modern discussions reflects the fear of the soon approaching Judgement Day and a crisis of confidence in the efficacy of the sacraments. In addition to institutional changes, all of this was reflected in the nascent demonology and witchcraft accusations. ${ }^{52}$

Augustine of Hippo had explained that people could make a deal with the Devil, and the earliest written evidence of a pact with the Devil is the story of Theophilus from Late Antiquity. The story was apparently written in Greek and translated into Latin in the 9th century. In the High Middle Ages, vernacular versions and other narrative examples of the pact were in circulation, and they demonised minorities like Jews, heretics and Muslims. ${ }^{53}$ The idea of the demonic pact emerged as a more immediate concern in the mid-15th century and at the end of the Renaissance. As early as in the first decades of the 15th century, court records began to mention witches making deals with the Devil and flying to the witches' Sabbath to celebrate the deal with dreadful orgies, child murders and other crimes. ${ }^{54}$ Old folk tales from around Europe describing striga women or benandanti men who fly like birds, shamanistic seers that travel to another world, and the traditional battles between good and evil began to merge with the Christian division of God and the Devil. Stereotypes of old conspiracy myths 
also began to seep in through the battles between God and the Devil and the clergy's authoritarian views. The alleged orgies, in which group members kill and eat children, rape their relatives and commit the worst sins and crimes imaginable, were similar to what other secret enemy groups had been imagined having done for ages. Such crimes have long been foisted on groups that threaten society or are feared by authorities. More important than what actually happened or even what people thought happened in a certain place at a certain time was the immemorial content of these myths. This content was then adapted in each trial to better suit the people's own worldview. ${ }^{55}$

Demonology essentially involves the witch making a pact with the Devil. Thomas Aquinas wrote in the 13th century that a pact with the Devil could be made tacitly and even unintentionally by an illicit ritual; verbal consent, a written pact or consummation of the deal by copulation was not required. Calling out to demons would make the pact explicit; it was an intent to make a formal contractual agreement. ${ }^{56}$ During the Middle Ages, the pact was not yet considered to have an irreversible outcome - it could be undone. Ideas changed in the early modern era: humans involved in such relations were obliged to pay homage to the Devil, and the pact was a result of either seduction or the witch's own initiative.

In early modern witch trials, male witches deliberately presented themselves as witches and sometimes also made deals with the Devil. More often than men, women seem to have unintentionally ended up in situations where they were considered to have made a pact with the Devil. The Devil could seduce men as well, but in both theoretical cases and actual trials applying demonology, men often seem to have done deals on purpose to gain power or succeed in war. The lower a soldier was in rank, the more likely it was that not getting killed counted as success. Benefiting from the deal was even considered a criterion for it being valid: if the man who signed the deal did not receive payment for selling his body and soul, there was reason to suspect that the Devil had not accepted the deal. In such cases, then, the matter was perhaps not witchcraft at all. ${ }^{57}$ In Sweden, for example, men usually took the initiative in making a written deal with the Devil, whereas women were tricked or seduced into the deal. When a person had faced adversity and was in a receptive state of mind, the Devil would appear and promise to turn things around by offering money, a husband or security in general, and sometimes even help in repaying wrongs. When the person accepted the Devil's offer, the Devil would brand his sign on the person and use the person for sexual purposes. After the Devil had raped the person, the promised money disappeared or turned to dead leaves, but it was too late to back out.

Both women and men gained magical powers and familiar spirits - some sort of embodied evil spirit or domestic demon - from the deal. Men had fewer familiars and used them to serve their own purposes and do mischief on their behalf. Women, in turn, had to feed the familiars upon their own bodies, and the familiars nevertheless did all sorts of mischief independently, even things witches did not want or tried to prevent. ${ }^{58}$ As Diane Purkiss points out, it was 
in the best interests of women to say that familiars were just like teenage boys or untrained dogs, always up to mischief despite their best efforts. This narrative was probably easier for them to believe as well. ${ }^{59}$ With demonological theories and trials for occult pacts feeding into one another, it is difficult to discern to what extent women's descriptions of their reluctance originate from demonology as opposed to women wanting to present themselves in the best possible light in court despite their difficult situation. Few men bragged in court about deciding to become a witch either. It is often impossible to determine whether a person ended up practising magic or threatening others with witchcraft out of volition or out of necessity.

Demonology, the study of the relationship between God and the Devil and the work of the Devil and demons, was born and soon gained importance in the 15 th century. Some historians think that this happened because the relationship between God and the Devil became an important part of people's worldview so quickly that no serious philosopher could ignore it. ${ }^{60}$ Others say that few bothered with demonology, but those that did, did so whole-heartedly. The latter group is probably right. Of the early modern philosophers, social scientists and theologians, few took any interest in witches, and of the ones that did, only a few believed witches posed a serious threat to Christendom. Others were interested in how the Devil could make some people think they were witches or trick a person's immediate circle into believing that the person was a witch, and yet others were appalled at how innocent people were harmed in the hunt for non-existent witches. Demonology never became a uniform science with united practitioners. As the theorists argued with each other, the mixed ingredients of the early ideas never formed a united witch theory. Furthermore, only a small number of the witch trials reflected any theory. ${ }^{61}$

Perhaps the most well-known and first proper demonological guide, the Malleus Maleficarum, published in 1486 or 1487, explained witchcraft in terms of women's insatiable carnal lust. This may have collided with other changes in society since in the early stages of the religious Reformations, attitudes towards sexuality did indeed grow stricter all over Europe. This is evidenced by the fact that illicit intercourse trials become more common, church marriages were emphasised increasingly, and the clergy had to constantly remind their flock that men should not be allowed to herd cattle alone. Nevertheless, negative attitudes towards sexuality did not cause the number of witches, witch literature, witch trials and witch-related concerns to grow. The fascination with demonic copulation exhibited by some demonologists may be explained by the misogyny of the church. Walter Stephens, however, argues that the verification of other aspects of Christian truths was the main motivation. Women copulating with demons would prove the reality of demons' bodily existence through the physical interaction and simultaneously verify Catholic dogmas, confirm the value of the sacraments, and hence support faith. Religious vindication, not prurience or misogyny, was the main motivator in his view. ${ }^{62}$ Demonic sex was an important element of the learned theories of demonology, but most witch theorists of 
early modern era - often lawyers - were not terribly interested in the sexuality of witches. Promiscuity was sometimes a background reason for accusations of witchcraft aimed at both men and women, but peer accusations in courts of law focused more on maleficium, harmful magic.

Researchers offer many interpretations for the narratives and rites of witches, and for their importance in society. Writing in 1966, Carlo Ginzburg seemed to consider tales of the benandanti witches' nocturnal flights to be true - or at least actual dreams people had - and interpreted them as vestiges of an old fertility cult. In 1975, Norman Cohn took a different stance: he explicitly states that all the tales were made up, as they probably were. ${ }^{63}$ The debate goes on and the positions scholars take depend greatly on the material they work with, because witch trials, too, were very different in different areas. For us, the 'truth' of the stories is not relevant. It does not necessarily even matter whether people thought the tales were true: it was enough that they began to think they might be true. When elements of various narratives collided, new narratives were born. They included some aspects that were old and familiar and some that were new and interesting. They also included something characteristic of the time and place of the tale or of its teller and audience. This made the narratives at least potentially credible. In any case, these new ideas spread just before the Reformations began, with both Catholics and Protestants pursuing witch trials equally eagerly.

Some of the key concepts of demonology, such as physical interaction and even copulation with demons, were present already in medieval theories. It may well have been the concept of the incubus, a demon in male form, that gave birth to the idea of physical interaction with demons. Sensual, even erotic elements were present in late medieval mystics' visions and experiences of divine love. The nuptial imagery and idea of the mystical marriage with Christ included ideas of desire, and Dyan Elliott has recently argued for a continuum between these phenomena. She sees an interrelation between the cultural changes involved in the rise of mysticism, the interest in demons and the birth of witchcraft theories: mystics' visions of the mystical marriage with Christ contributed to the idea of women having intercourse with spiritual creatures - in other words witches copulating with the Devil. ${ }^{64}$

The association between demonic sex and wedlock was proposed in the medieval didactic material. For example, Caesar of Heisterbach told a story of an illegitimate daughter of a priest named Arnoldus; she was seduced and defiled by a demon. The unnamed daughter was very beautiful and an object of interest to young men in general and to the clerics of Bonn - her hometown - in particular. Apparently, Arnoldus was aware of the libidinous desires of men and the frailty of feminine virtue, since he guarded his daughter attentively. He used to lock her up in the yard of the house when he went out. These precautions were insufficient, since the Devil appeared in the house and tried to make the girl to fall in love with him using flattering words. ${ }^{65}$

The loss of virginity lies at the heart of Caesar's other stories. There was a need for this kind of cautionary tale as virginity was the ideal model for the 
potential reader, particularly the nuns for whom the stories of The Dialogue on Miracles were also read. ${ }^{66}$ This case, however, illuminates how cultural and societal changes, and not just misogyny, may have provided material for demonic copulation. Excessive emotions and a lack of mental strength were qualities typically linked with femininity, and they, rather than unstoppable lust, seem to have been the reason for the moral stumbling of the priest's daughter: the poor thing (misera) gave in to temptation and was corrupted, and the Devil took her several times onto the path of sin. One day Arnoldus found her crying in misery, and eventually she confessed what had happened. As a result of the diabolic tricks and her own anguish, the girl was so gravely afflicted and out of her mind that she put worms in her mouth. Eating worms was a clear sign of alienation, even animalisation; the girl was transgressing the boundaries of human behaviour. ${ }^{67}$ The saddened father sent his daughter over the Rhine hoping that the change of air would ameliorate her condition. Changing location was also one of the remedies demonologist Johannes Nieder suggested in the 15th century for those suffering from sexual assaults by an incubus or succubus. The others were prayer, making the sign of the cross, exorcism and confession; for the change of location, Nieder referred to this earlier narration of Arnoldus' daughter. ${ }^{68}$

At first glance, the case of Arnoldus' daughter seems to underline the much repeated topos of women's lustfulness and moral fragility. However, there are other potential links to $\sin$ in this case. The girl was not tormented only for her own moral weaknesses but for her father's vices, too. After all, she was the illegitimate daughter of a priest. The Dialogue on Miracles was written down soon after the Fourth Lateran Council, where the requirement of clerical celibacy was yet again asserted. Her torments underline the idea that the sins of the parents could be avenged upon their children (Exodus 20:4-6). Caesar's text is rather well-known for his tolerant attitude towards women, and the condemnation of feminine lust does not seem to be his main message. For example, after the next tale in the compilation (about a woman voluntarily having sex with a demon for years), a monk and novice discuss the moral dangers demons pose to Christians. Echoing the prevailing ideas about femininity, the novice argues that women should be very alert to the danger of giving consent to demons or offering them an opportunity to have sex with and corrupt women. However, the monk contests this claim, explaining: 'It is not only for the women to be alert but men, as well. As is said, demons in the male form tease and corrupt women, but so in the female form they seduce and deceive men' ${ }^{69}$

The tale of the priest's daughter did not end with the girl's translocation, however. After she was gone, the demon appeared to the father, asking where the priest had sent his wife. The demon gripped the priest so violently that he died within three days. Thus, in this case, the sexual relationship was directly likened to wedlock. However, the intention may have not been only to underline the submissive position of the priest's daughter to the Devil, not to mention the accusation of witchcraft. Caesar's intention was to emphasise the linkage between the father and the Devil: the obvious message seems to have been the 
equation of a demon taking a wife with a priest doing the same: the true diabolical sex took place between the priest and his concubine.

The idea of copulation was not only an elite fantasy, since in the early modern era, confessions of a certain type in witchcraft trials did involve admitting to sexual relations with the Devil. In these cases, sexual relations were a part of the story that had to be told for the witness statement to be credible. According to Lyndal Roper, German women were made to say they were married to the Devil because according to the period's notion of marriage, that made them subordinate to the Devil. According to traditional legal views, marriage could not exist without sexual intercourse. Roper argues that the stories also reflect the women's own, less than encouraging experiences of their worldly marriages: many of the women she studied did not make a deal with the Devil until after their earthly husbands had left them in the lurch. ${ }^{70}$ The guidebook the judges and interviewers had read determined how much prominence marriage and intercourse with the Devil had in the trials. In most cases, it was not discussed at all; most trials focused on the damage the accused witch had caused according to regular earthly laws. Not all trials, then, relied on any demonological guides, and most guides never mentioned intercourse with or marriage to the Devil.

\section{Demonology, witchcraft and gender}

One of the oldest feminist interpretations of witch-hunts claims that they were a way of branding and judging women who did not quietly remain in the shelter of the home. ${ }^{71}$ Even now, many writers think that accusations of witchcraft were mainly the result of women assuming masculine roles either as landowners or professionals in trade, fishing and travelling. ${ }^{72}$ However, the reasons behind witch-hunts are not so simple. On the one hand, nearly all women (and men) accused of witchcraft were active members of their community, and their activities meant they met other villagers. Although women accused of witchcraft often tended to typically perform women's duties, such as rearing cattle and churning butter, or unisex duties, such as brewing beer and fishing, their duties did not confine them to their homes. Women took cows to pasture, went to the beach to fish and sold beer in public. The accused women seemed aggressive in demanding their rights - sometimes very aggressive. They also seemed keen to interfere in other people's business. On the other hand, they were hardly accused of witchcraft simply for being active, demanding their rights or breaking some gender norms, because so did many other women who were never accused of witchcraft or anything else at all.

An examination of the sex ratios among those accused of witchcraft in early modern Europe is nevertheless required before questions of gender and witchcraft can be assessed. In Europe, our understanding of the sex ratios has changed due to research made on new materials and new sets of trials. According to current statistics (by Levack, Schulte, and Apps and Gow), women most often made up between sixty and eighty per cent of those accused. In some places, such as the 
Holy Roman Empire, the Habsburg empire (including such places as the Bishopric of Basel, the County of Namur and sometimes Austrian Hungary, which did not formally belong to the Holy Roman Empire), the County of Essex and the Wielkopolska region in Poland, the proportion of women accused was even higher. On the other hand, Iceland, Estonia, Finland, Russia and Normandy saw lower proportions of women accused and consequently higher proportions of men $(90 \%$ in Iceland, $60 \%$ in Estonia, around 50\% in Finland and $70 \%$ in Normandy). ${ }^{73}$

There are numerous problems with such statistics. Homogenising the widely varying conditions - such as the competing cities, bishoprics and principalities of the Holy Roman Empire - into a unified geographical entity obscures the fact that witch-hunts even in neighbouring towns were often very different in terms of both intensity and sex ratios. The statistics usually concern uneven periods of time and vary from almost three centuries in Poland (1500-1775) and Finland (1500-1800) to just a few decades in places like Toul or Aragon. The example of Finland shows that sex ratios can change quickly over time: during the first 150-year period from 1500 onwards, most witches were men, although a few women appeared occasionally. However, during the most intensive period of witch trials, from 1660-1700 - a time when new kinds of witchcraft accusations involving the witches' Sabbath and various forms of superstitious magic became common - women came to form the majority of the accused. During the 18th century, women became nearly invisible once again: eighty-five per cent of the accused during this period were men. ${ }^{74}$

The apparent heartlands of the witch-hunts - the Holy Roman Empire, France and Scotland - were dominated by the stereotype of the female witch. The peripheries, on the other hand, especially the north-east of Europe, but also Normandy in the west, maintained the stereotype of the male witch. These concepts of centre and periphery are not necessarily geographical or cultural; rather, they are related to the intensity of the witch-hunts. The proportion of men seems to be greater in the less intense and moderate hunts, such as in Iceland, with its 120 accused between 1625 and 1685, and in Estonia with under 200 accused between 1520 and 1729. The countries that blur this picture are Russia, with almost 600 accused between 1622 and 1785, and Finland, with at least 2,500 accused between 1500 and 1800. These two countries were geographically large though sparsely populated, which means that it is not easy to compare them with densely populated European cities. Russia and Finland can also be thought of as areas with low intensity witch-hunts, because although the trials were frequent, they were also conducted meticulously according to due legal procedure and the punishments were usually milder than those received further west. ${ }^{75}$

One can thus claim that the areas with intense witch-hunts saw a greater proportion of women as witches than areas with less intensive hunts. This seems to contradict Erik Midelfort and others, who claimed that men as witches often appeared in the trials only after the hunt had intensified, and the social characteristics of the witch had been complicated by a snowball-effect whereby the 
male friends and relatives of previously accused women were linked by association and chains of accusations. ${ }^{76}$ Nevertheless, the focus on intensive witchhunting is a crude generalisation and offers a rather one-sided look at witchcraft and magic, including in terms of how gender worked in the trials. If one seeks to find out more about the gendered concepts of magic in early modern Europe, one should consider the other characteristics of both the trials and the society in which they took place.

Witch-hunts were usually at their most intense where the idea of the witches' Sabbath took root. In their purest form, the witches' Sabbath trials took place in Germany and France, but they occurred occasionally in other countries as well. This Sabbath - where witches were said to congregate - was essential for chain accusations and snowballing denunciations. The majority of the accused in the Sabbath trials were women. This has been explained by the sexual nature of the Sabbath and the encounters between the witches and the Devil. Nevertheless, in Continental Europe, the concept of the witches' Sabbath grew to include men. Although it was never impossible for demonologists to conceive of female demons and devils having sex with human men, sex was not as important for the masculine experience of witchcraft. This was possibly the case because, as Lyndal Roper claims, ${ }^{77}$ early modern understanding related sex to the subordination of the woman to the power of the man. During the witches' Sabbath, men took on other roles. Rita Voltmer and Peter Heuser found that in German witch-hunts, a wider cultural development was perhaps more important to the change than the escalation of chain accusations. The emergence of men as witches was made possible by the reimagining of the witches' Sabbath in terms of the village festival; men took roles in the witches' Sabbath that corresponded to their roles in the village festival. This reimagining, rather than a simple escalation of accusations, was the cause of the emergence of the male witch. ${ }^{78}$ The Sabbath has also been described as the mirror image of society in general, which may also lead to seeing its main figures as men, just as in everyday society. ${ }^{79}$

Finland and Sweden had a few trials that involved the witches' Sabbath and Blåkulla, the place where witches gathered to celebrate. In Finland, these trials were mainly held in the Swedish-speaking areas of Ostrobothnia and Åland, suggesting that Sweden had a significant influence. On 28 May 1666, Karin Persdotter from Enkarby, already sentenced to death by beheading and burning at the stake by the Aland circuit court, was presented at Turku Court of Appeal. She had been sentenced because she had had 'a connection and a union with Satan and been able to say when something had been stolen and by whom'. Maria and Brita from Engeby were also presented before the court of appeal for supposedly having been enticed to practise witchcraft by Karin, but they were only sentenced to forty-mark fines. Contrary to its practice, the court of appeal did not pardon Karin but explicitly ordered her to be carefully questioned before her beheading about who else had been involved in witchcraft so that they could also be examined and brought to justice. ${ }^{80}$

Later that autumn, Maria Nilsdotter from Finnström and a number of other women named by Karin Persdotter were also brought to court. Maria had a 
connection and union with Satan that helped her cure diseases with magic. She had received a death sentence in the circuit court. In Maria's case, too, the court of appeal enforced her sentence. Because the other women were yet to be investigated and sentenced, circuit court judge Nils Psilander was told to bring the women together before the beheading and to listen to Maria's entire confession before the named women. The circuit court judge was to hear the women's responses to Maria's confession and to write everything down carefully. These women were then to be investigated so that the court of appeal could make the final ruling on their cases as well. ${ }^{81}$

In the February of the following year, the cases were presented at the court of appeal. Lisbetta from Sund was sent to the court of appeal for practising common witchcraft, making a deal with the Devil in Blåkulla, and then paying him an annual butter tax. When she first came to Blåkulla, Satan had branded her shoulder and announced that her body and soul were now his. Ebba, Mats Henrickson's widow from Finby, was investigated at the same time. She offered a similar confession and said she had been in a union with Satan for two years. The union offered her better luck with butter and crops, and in return she paid the Devil one talent of butter a year. The Devil had bitten Ebba, too - on the right shoulder - to mark that her body and soul now belonged to him. Neither woman was pardoned by the court of appeal. A similar story of a deal and butter tax was offered by Anna Bengtsdotter from Sund, yet another woman the court of appeal did not spare. ${ }^{82}$

In total, seven women were sentenced to death. The events had begun to unfold in 1665 in Jomala, where hay had been stolen from Mats Pålsson. The thief had been caught with 'information' given by Karin Persdotter. Karin was questioned about her trips to Blåkulla and any orgies she might have attended, after which the court was convinced that she was in open alliance with Satan. ${ }^{83}$ Karin explained that the Devil had scolded her for being poor and threatened that she would always remain poor unless she began to serve the Devil and pay tax to him. Although this did not interest the court of appeal, the Devil had bitten Karin's breasts so that the marks were still visible.

This series of trials was highly unusual: they were the first Sabbath trials in Sweden and included many features that never became common. Above all, they included an unusually high number of features discussed by demonologists: Satan was personally present, and the women were in an explicit union with him. These features were gendered and partly sexual, but whereas the women in Germany were made to describe how they had sealed their pact by a symbolic marriage with - or a rape by - the Devil, the Finnish women described having confirmed the union by paying taxes of butter and money. This was no less gendered than the stories in German areas, but clearly in a different way, and the details were more connected to the women's civic and economic roles than their sexual roles. The Devil himself was portrayed as a young man in a sailor's outfit - a coastal variation of the figure that appeared in some German witchcraft narratives - a gentleman dressed in black velvet. ${ }^{84}$ 
The accused women in Aland never told much about the Sabbath they had attended. Much more emphasis was placed on the magic they performed in their home villages, mostly in their homes, cattle sheds and pastures. The accused women fairly freely testified that they had recited the Lord's Prayer to protect their cattle. Karin gave her cows special fodder to protect them from disease saying, 'My cow has been robbed of spirit, my cow has been robbed of blood, my cow has been robbed of flesh, but I will give you malt and salt, and you will get your strength back'. Thereafter, she said the Lord's Prayer. ${ }^{85}$ Lisbetta said she had let her cows out together with the rhyme 'you shall go after me, like the Devil goes after the wrong master, and like the one who goes to court and knows right but testifies wrong. ${ }^{86}$ Later on, one of the women also testified to having read a long reading to the cows; however, the witness could only remember that she said to the cows, 'you shall want me like the poor soul wants the Realm of God, or like the earth wants fresh water'. ${ }^{87}$ Though they were sentenced for misusing the name of God, they sought to present themselves as fulfilling their gendered economic roles with religious piety in a manner that could have reflected Luther's ideas of calling and vocation, had their actions not encroached upon the clergy's role as the dispenser of prayer and divine intervention. The narratives of women's witchcraft were firmly embedded in the everyday, but also in religious expectations. The narratives also suggest that the women seem to have thought it worthwhile to seek divine help in their daily duties. Instead of a vengeful God, they saw - at least until they faced torture in the witch trials - a God that was a potential help, even for a lowly woman with a sick cow. The spiritual came into the material and bodily world.

Among the educated elites at least, and through teaching and more or less top-down cultural transmission, the female stereotype of the witch was wellestablished. Demonologists writing on the subject are usually considered indicative: Stuart Clark has concluded that due to a deep-rooted, long-standing dualism in early modern categories of thinking, witchcraft, along with inferiority, was associated with women. By contrast, all good and appreciable things were associated with men. According to Clark, this was not a conscious misogyny, but rather an implicit characteristic of the early modern learned way of thinking. Clark's claim that prejudice was inbuilt, unintentional, and unrecognised actually means that it was not the individual demonologists or witch-hunters who were misogynists; rather, it was the culture and society as a whole. ${ }^{88}$

Scholars in the 21st century have amended Clark's argument: instead of a dualistic polarisation of opposites, gender is now most often seen as a web of assumptions or latent qualities that could be drawn on as the situation needed. This web of assumptions was 'not so polarised as to prevent leakage across gender boundaries'. ${ }^{89}$ A similar development has led to the argument that stereotypically feminine qualities could well be attached to individuals of both sexes: some men could be imagined to be like women, and therefore witches. According to Claudia Opitz-Belakhal, Jean Bodin regarded some educated men's greed for power and knowledge as prone to make them as vulnerable to the Devil's lures 
as women's carnal greed. Whereas Bodin associated his enemies with greed, witchcraft and femininity, he also presented himself as godly, dutiful, virile and, with this combination, ultimately very masculine. ${ }^{90}$ It was obviously also possible to use witchcraft accusations to present a godly and dutiful femininity. It is also likely that witchcraft sceptics and the more cautious judges were equally able to identify their rationality and patriarchal position as reflecting masculine qualities. $^{91}$

Gendered beliefs about magic have also been formed by various other agendas. For example, Sigrid Brauner, Merry Wiesner-Hanks and Rolf Schulte have claimed that Protestant ideologists - including and especially Luther - either adopted or retained for longer the stereotypical image of witches being female. ${ }^{92}$ While this may seem a viable generalisation, it is noteworthy that in the majority of the areas where most of the accused were men, the dominant religion was Protestantism. ${ }^{93}$ The influence of the Eastern Orthodox religions and Islam on gendered concepts of witchcraft and magic has not yet received much serious assessment, although the issue must be of significant relevance since geographically, more than a third of Europe was under the influence of these religions.

The demonologists' stereotype of the female witch was not necessarily transferred into the practice of trials or the popular concepts of witchcraft. Both women and men could be witches, but female and male witches differed from each other. In peasant cultures, the differences were so varied that they are somewhat difficult to analyse. They also do not necessarily go hand in hand with the 'goodness' or 'evilness' of witches, or with their scariness, powerfulness or appreciation, although many researchers have tried to view them in this way. In the 1970s, feminist researchers assumed that women were actually the good witches, healers and midwives, but that the elites branded them evil. Men, on the other hand, were more often occultists, practitioners of 'high magic', or astrologers who worked in courts and palaces and were thus rarely reached by the authorities. These assumptions were based on a limited amount of learned literature with political rhetoric and a couple of pamphlets describing trials. More recent research comes closer to presenting statistics about actual trials. Modern researchers often state that in the Netherlands, Sweden and some German cities, for example, men acted more often as so-called wise men, healers and mediators in marital disagreements. For these men, witchcraft seems more often to have been a way to gain a higher status than for women. ${ }^{94}$

At times, the differences between women and men as witches seemed to reflect the division of labour between the sexes in general. There are two possible explanations for this. One explanation is that women did magic relating to women's work and men did magic relating to men's work. Sometimes men and women acted as village healers or mediators in marital disagreements - and sometimes as saboteurs. Another explanation is that women's actions in the men's sphere were easily interpreted as witchcraft. For example, 19th-century Finnish folklore shows that if a woman so much as touched a horse's harness, it became unlucky. ${ }^{95}$ The other explanation comes from statistics presented by 
Marko Nenonen in 1992: both the number of women charged and the number of charges for benevolent cattle magic increased simultaneously after the 1660s. At first glance, it would be easy to think that women were involved in benevolent cattle magic and men in maleficium, but Nenonen claims this is a statistical fallacy: the two things simply changed at the same time. Although the phenomena seem to correlate, they are in fact entirely independent of each other, much like ice cream consumption and death by drowning. The fact is rather that before the 1660s, witchcraft charges dealt almost entirely with maleficium, meaning that nobody was accused of benevolent cattle magic. Also before the 1660 s, women were not charged with anything at all, meaning that women were not charged with maleficium before this. After the 1660s, however, two things changed: witchcraft charges began to focus on benevolent magic and women began to be charged. These coinciding changes cannot be used to deduce that men or women performed more of either type of magic, but that gender expectations were changed by the Sabbath trials in the late 1660s. ${ }^{96}$

The line between benevolent and malevolent magic is fine, because it depends on whose point of view is considered. Exposing a thief may sound like benevolent magic at first, but the matter was complicated by the fact that the thief was often uncovered after some accident happened to him. Some magic was similar to theft. Examples include taking a few straws of hay from your neighbour's barn and putting them in yours or cutting a few meshes from your neighbour's nets and adding them to your own to guarantee sufficient feed and a good catch. ${ }^{97}$ Categorising magic into benevolent and malevolent may not be useful in the first place, and it certainly does not distinguish women's magic from men's magic. ${ }^{98}$ In the early modern period, men healed, did magic and cast spells on cattle, food, beer and children, even if these were typically associated with women's magic. Conversely, women cast spells on horses, fields and trees that fell in forestry work almost as often as they did so-called women's magic.

\section{Sin and faith embodied}

Though catering to the needs of a patriarchal society and though hierarchical by nature, pre-modern religion was not necessarily oppressive towards either gender. Historians of religion have emphasised that among theologians and in spiritual instruction, 'feeling like a woman' was not a disparagement. ${ }^{99}$ The phrase referenced Christ's bride in the mystical union between the church and the Divine. Moreover, the corporeality of Christ and his sacrifice, which lay at the heart of Christianity, was considered symbolically feminine by the late medieval period. Since women were considered to be more carnal than men, women could also more easily identify and be identified with the incarnate nature of Christ, and to share in the suffering that was supposed to free humankind from sin. Thus, to take part in the imitation of Christ, men who wished to be leaders of the congregation also had to present themselves as imitating women. This is visible in a number of late medieval pious instruction manuals and meditation texts. ${ }^{100}$ 
Even though this was of course a symbolic and ideological discourse rather than a pragmatic or political one, it also had implications in lay piety and thereby the practical life of the parishioners. The feminine was therefore not necessarily hierarchically less preferential to the masculine, although some scholars emphasise that this reversal of roles was only temporary. ${ }^{101}$ Whereas the importance of such imitation diminished with religious mysticism in many forms of Protestantism, mysticism did not wholly disappear from even the most orthodox Lutheranism. On the contrary, it had a role in Lutheran religious experiences, even in Luther's own descriptions of his awakening, and later in the personal cults that developed. In other words, the portrayal of masculinity among Lutherans always included a dimension of femininity, frailty and ecstasy. ${ }^{102}$

There were other kinds of religious performances as well, those not so much directed towards the maintenance of social order. Post-Reformation prayer meetings were one such element. It is clear that a prayer continued to be a performance also after the Reformations. More specifically, it was a bodily performance much more than a verbal utterance or unspoken thought. In the western part of Finland, and particularly so in Satakunta on the south-west coast of Finland, traces of a rosary cult can be found in the mid-17th century. The court records of the rosary practice show that Marian devotion channelled religious feelings in Finland during this time. In 1646, a group of women from Huittinen were indicted for having held a convent or a 'Resolia' at home in order to improve the failing eyesight of one of the village women. When indicted for superstition and questioned in court, the women reported that they had read a sequence of prayers nine times, prepared and consumed a special sacrificial dinner with beer on the table, and held hands and struck 'with iron on flint stone'. ${ }^{103}$

While prayer was difficult to define in the early modern period - just as it is now - the women themselves thought of and called these actions prayer. Other comparable events in the court records include cases where the agents themselves call an action a prayer and they refer to a (usually Christian) Divinity - although others around them may have thought of the same actions as being a joke or superstition, sometimes even a blasphemy. All the above-mentioned characteristics were typical elements of early modern prayer as described in the court records. Prayer was not merely a litany of words; rather, it consisted of series of tangible and ritual actions, such as kneeling in front of or beside the target of the prayer, or else touching or circling it - the sick person, the damaged limb or the endangered field. Eating was also an important part of the lay prayer meeting, implicating both the Holy Communion and the bodily engagement of the participants, and it should not be separated from the meeting.

Scholars of medieval religion have investigated contemporary devotional manuals as affective scripts where the pious exercise was constructed from sequences and little actions that followed one another. If performed correctly, they would not only present but also produce the desired religious experience and religious emotion. In these texts, they were often small exclamations and short adjectival descriptions that functioned as emotives - expressions that were 
meant to signify and communicate emotion as an interpretative explanation both to others and to oneself. They were a means to communicate things that went on in one's mind internally. ${ }^{104}$ The early modern Finns were barely literate, and few descriptions of the verbal parts of prayer are available. However, what the women told of their prayer rituals suggest that they also functioned as a script, but a script that materialised in action and in the body instead of through words and phrases. When groups of women performed the bodily rituals together, it was meant to produce a shared experience of the sacred and of the expectation and granting of divine help, conveyed by the body. ${ }^{105}$

The shared meal was part of these meetings. Eating was important for various reasons. In magical thinking, making someone eat something was a way to gain access to the inside of the body and thereby have power over it and the soul that dwelled within. ${ }^{106}$ Eating together was also important because it connected the individual body with its private sensations to the community that shared the meal. Eating, especially ritual eating influenced by the sacrificial communion, also connected in a tangible and accessible way the mundane and daily to the sacred and religious. This was no less important in Protestant and Lutheran culture than it had been in the medieval Catholic culture. In fact, the importance of the physical experience of partaking in the Communion may have been emphasised in Lutheranism. ${ }^{107}$ Many court cases report how the parishioners took communion into their own hands and celebrated it outside church. Nevertheless, even in indictments of blasphemy and superstition, most cases testify to the respect shown towards communion. Using communion bread and sometimes even wine for magical purposes, in healing for example, presumes that the items were thought of as holy and powerful, having an effect not only spiritually but also physically. The Lutheran communion was a bodily experience of the divine body; it was not a commemorative meal but a true meeting with the essence of the flesh and blood of Christ, which were made a part of the human body by consuming them and which thereby sanctified the human body, at least for a moment. Not only in church communion but also in the unofficial sacrificial meals, the religious experience was shared in a physical form. The physical and bodily also made the experience sexed and gendered.

This shared physical experience of the sacred or religious could then be used to define the limits or the order of the community. The Huittinen prayer meeting mentioned above had been organised because a woman in the village was losing her eyesight. All the participants stated that their prayer had been successful, and she was now 'better'. Regardless of whether she actually saw any more clearly than before, the shared ritual had shown that she was a still a member of the community, although her place within it may have been changing. The ritual was also a way of recognising this change, the transformation from someone who could and would be expected to work for the community to someone who needed and would receive help. The ritual signified that this change was accepted and legitimate; it was not a matter of idleness, laziness or sin. If in the pre-modern context being well or healthy meant fulfilling the expectations posed, ${ }^{108}$ this woman was certainly better again. 
Such a ritual embodied compassion, one of the key religious emotions in the pre-modern period, in a tangible, physical expression that took place by doing things: cooking, eating, stepping and kneeling. Believers touched or circled a thing by walking or crawling around it to invoke the holy power embodied in a church, shrine, statue or well, or else they walked around an item, space, animal or person in order to provide the protection of the holy power. They included their fellows in their rituals by doing things together and sharing the physical action. The phenomenon is much like that described in Saba Mahmood's (2005) influential ethnographic work on the women's mosque movement in contemporary Egypt, which highlights that the religious experience of women occurs in and through the body, and that piety is an embodied practice. Likewise, according to Caroline Walker Bynum, the body was constitutive of the religious self in Medieval Christian teaching. ${ }^{109}$ The early modern believers, who touched, ate and walked in their prayers, similarly performed religion with their bodies rather than - or in addition to - words. Their bodily performances of prayer also made religion and faith tangible and concrete, giving it meaning but not turning it into a mere ceremony. Simultaneously, it brought religion-as-lived into the mundane spaces outside the church.

Corporeality shaped religious experiences differently for men and women. One of these differences may have been that while both men's and women's bodies where thought of as porous and permeable, women's bodies were thought to be more so. ${ }^{110}$ Women's bodies were leaky vessels that did not always contain their bodily fluids. They could be more easily entered into by spirits and malicious people as well as by well-meaning magic, but they were also overflowing with emotion and spirituality, not governed by order and structure. This was partly what made the symbolic paradox of spirituality because of corporeality so strong. Therefore, as McNamer puts it:

Recognizing that gender performance became an enduring, core mechanism for the production of this emotion not only helps to explain the historically specific social and ethical functions of compassion in late medieval England, it also helps expose emotion-driven fractures within so-called traditional religion - especially in the meditative practices of powerful lay men - at the cusp of the Reformation. ${ }^{111}$

Compassion, essential for the imitation of Christ, was largely a gender performance: to perform compassion was to feel like a woman. Compassionate feeling and religious performance for the benefit of others was first and foremost a woman's devotion.

The spiritual and the bodily were always intertwined, but for women, they were even more so. This difference may have increased during the Reformations' emphasis on order, regulation and self-government as essential ingredients of masculinity, particularly religious masculinity. ${ }^{112}$ Mysticism was not absent from Protestantism, especially from Lutheranism, and the Catholic Reformation 
relished the mystical and the miraculous, but during the 16 th and 17 th centuries, even mystical experiences had to be controlled.

This may explain one difference that can be found in men's and women's bodily religious practices in early modern Finland. It appears that regular, calendar-related feasts were often celebrated and the rituals conducted by men, like the celebration in Jääski in the previous chapter. In the context of immediate emergencies, however - when someone fell ill or needed help, as happened in Huittinen, women more often took charge. This was not a cast-iron rule, however: there were many women taking part in the annual feasts, and there were also calendar rituals specifically for women - for example, letting out the cattle - and men took sometimes part in the emergency magic as well. However, more often the formal rituals were performed by men and the informal rituals by women. ${ }^{113}$

It appears that the practices supported a gendered sense of belonging to a group of similar people, either to other men or women, or to a kin or family group. The gendering of religious practices and the emotions acted out in them were much more directly related to other people in the immediately surrounding community. Compassion for a neighbour with failing eyesight was not sought through imagining Mary's suffering, but through tangible work with one's neighbours to begin the charitable care in terms of the food, clothing, and company that the member of the community needed. Compassion was a decent woman's proper feeling, but it was also the feeling of a woman in a certain tangible social and geographical religious group. Men, on the other hand, did not perform the rituals to produce compassion; their rituals were for reproducing appreciation and a sense of authority. It is a simplification - but it may be a useful one - to claim that women's rituals centred on compassion and help in emergencies, while men's rituals centred on order in the everyday.

\section{Conclusions}

The internal hierarchy and gender order followed and taught by the church was not a self-evident truth. The church's own conflicting notions are evident in the problems the medieval church faced in defining women's religiousness. The church sometimes struggled to draw the line between an ascetic mystic and a person possessed by a demon, between a woman prophesying and a heretic spreading misbeliefs. Definitions were not made by clergymen alone. Ordinary Christians, men and women, no doubt experienced religion as something that restricted and controlled them, but it also offered them new opportunities. The church determined how religion should be practised by requiring annual confessions and penances, but it also left individuals with plenty of freedom to choose. Religion thus offered women the freedom and space to fulfil themselves and sometimes even the opportunity to take down gendered behavioural norms. Most of women's religious activities nevertheless did support the church's patriarchal structures, and very often, women's actions enforced the prevailing 
gender order and hierarchy. In particular, women ascetics' eucharistic mysticism and fanaticism strengthened the position of the priests offering communion. Similarly, women's private religious practices, such as pilgrimages, supported the definition and network of the sacred places created by men. ${ }^{114}$ While the performance of virginity inserted queer elements into femininity; at the same time it produced a dualistic - even complementary - gender order: the confessor guarded and mediated the ecstatic mystics' experiences for the wider audience to comprehend and cherish.

Late medieval and early modern Christianity, both Protestant and Catholic, may have worked on the platform of neo-Platonic binaries that organised the world into pairs of opposites, such as black and white, light and darkness, and men and women, but it also seems to have flirted with paradoxical inversions of the same binaries - the performance of religion required the queering of gender. To be righteous, it was necessary to be humble, to be saved it was necessary to feel the enormous weight of the sin one carried and to beg for forgiveness. This paradox led to different expressions in Protestantism and Catholicism, but it was important in both. The Protestant idea of salvation by faith alone was based on the inability of humans to avoid sin. Therefore, flawed, sinful humans could only be saved if they admitted to their sinfulness and submitted to divine grace. The Catholic Reformation's focus on the figure of Mary Magdalene and the church's expenditure on refuges for fallen women indicate a similar quest to identify and associate virtue with the sinful. It became a competition to present oneself as the worst sinner, the weakest vessel, for the early modern believer took pride in being as humble as possible. ${ }^{115}$

Obviously, this was not a new idea; it drew from the Bible and was largely cultivated during the Middle Ages. The humility topos was a well-known and widely fostered element in medieval religious writings. Humility was a virtue and the counterpart to the capital sin of pride. It was the first step on the path to salvation; therefore, authors could willingly use it as an element of spiritual merit. Those that were the most humble were the most deserving of redemption. ${ }^{116}$

Medieval and early modern Christians believed not only in communal and individual $\sin$ and salvation but also in the idea that 'the last will be first, and the first last' (Matthew 20:16). Sin and virtue, humility and pride, and freedom and servitude to God formed binary pairs that were constantly inverted; they intermingled and eventually formed paradoxes in which sin and virtue did not exist without each other - humility was pride, and servitude was freedom. The identity and subjectivity of the religious self was formed in this submission to rules and the whole that was mightier than oneself. ${ }^{117}$ While categories of male and female sex as physical or biological entities did not share in this blurring, the social and cultural categories of feminine and masculine gendering did.

In this context, the concept of gender also changed. Instead of considering it a hierarchy, historians of religion usually approach gender as a matrix or a web of qualities that could be drawn upon by people to present themselves as religiously successful men or women. These qualities fall less clearly into neo-platonic 
categories, and therefore both men and women drew on the same qualities, albeit perhaps in different situations and for different ends. The question is or was, therefore, not so much what men or women did or were able to do in terms of religion, but how they did it. How did men perform religion to be good men, or women to be good women? While these performances were certainly regulated, as Judith Butler has pointed out, ${ }^{118}$ early modern and medieval regulation was not self-evidently similar to modern religious regulation, and although it operated on binaries - the categories of masculine and feminine - medieval and early modern Christianity's play with paradoxes set their asymmetric hierarchy in a continuous swinging motion. To be masculine, men had to be feminine. The same applied also vice versa to women, as testified by a number of medieval saints' vitae describing fasting even until the bodily signs of femininity disappeared or by Protestant descriptions of women taking up masculine tasks and roles in the absence of 'good and Godly' - that is, of course, Protestant - men. ${ }^{119}$

Thus, gender turns into a performative project: it is something people do and therefore appropriate and change - instead of what they are, and it is something that people qualify, instead of something that qualifies them. Together, gender and religion formed a performative space, a stage that empowered people to do things and qualify the way they did things.

When the human body is brought to the centre of any investigation, it inevitably turns into a gendered body. But what does this mean? The gendering of bodies is not a self-evident and unchanging factor; it was different in the period under scrutiny from how it is now. Bodies were not only used to produce experience and religion; religion was used to produce the body. This is clear in the examples of this chapter: Clare of Montefalco's patient endurance of illness, naked Birgitta kneeling in prayer, the visible marks the Devil was thought to have left on the bodies of his victims, and the curing of the eyesight of the woman in Huittinen. All this is reminiscent of the way the body and gender have been approached in studies on Islam and Islamic cultures. Bodily performances and the experiences of the body moving and acting transform the self and allow it to pass through different normative regimes governed by different sets of formal or informal rules, norms and expectations. The body is not 'a mere receptacle or "inscriptive surface" for the work of representation-cum-discourse' of religion; rather, ' $[\mathrm{t}]$ he body and bodily practices are central to the enactment of sacred space'. ${ }^{120}$ In other words, the body is an agent itself that shapes the spiritual experience of a conscious human subject. It is not merely an outward representation or a tool. Religion-as-experience or experiencing religion was holistic, including both body and mind not detaching them into binary categories.

Religion is an elaborate construction of complex and conflicting human minds. Late medieval and early modern Christianity, both Protestant and Catholic, may have operated on a platform of neo-Platonic binaries, but it continuously flirted with paradoxical inversions of the binaries. To be saved and righteous, it was necessary to confess to one's unavoidable sinfulness, and the early modern believer took pride in being as humble as possible. Sin and virtue, humility and 
pride, and freedom and servitude to God formed binary pairs that were constantly turned upside down and eventually turned into paradoxes in which sin and virtue did not exist without each other. Humility became pride, and servitude became freedom. The social and cultural categories of the feminine and the masculine were blurred and their relationship made more symmetrical. Feeling like a woman could be essential for the successful presentation of religious masculinity. Gender included hierarchies, but no longer permanently unbalanced relationships of 'power over'. It turned into a quality - or a web of qualities - that empowered people to do things, a performative project of identity in the Butlerian vein of thinking.

In the religious rituals of early modern lay people, the gender roles related to everyday life and livelihood for each and every status were reinforced in the sphere of the sacred. The religious experiences enforced and moulded gendered roles in the family and community, but gender also produced religious experiences and identities through shared and individual communal and bodily practices. These experiences could be restrictive, since the sharedness meant that they had to be at least partly approved by others, but they could also be empowering and constructive, as they allowed a negotiation of individual and communal identity.

In this chapter on medieval and early modern sin and faith, we have also discussed the obvious importance of the body and the material in religion and gender. Both religion and gender are, after all, things that need to be done lived - in the everyday, and although the medieval and early modern everyday included many non-material beings and things, for humans their very existence, let alone doing and performing, needed the body. So the body also guided the experience of both faith and of gender. The body also guided the experiences of lacking or or not fitting in in either faith or gender. And although the body in the medieval or early modern period was never understood as dualistically separate from the mind or the spirit - of which medieval saints like Birgitta of Sweden were examples - she became virginal sponsa Christi when she devoted herself to the religious life, long after she had married and born children. The body and the mind were not separate, not perhaps even intertwined or interdependent, but rather amalgamated in the human - or Christian - person.

The bodily nature of doing religion and gender gave the experiences of faith or gender a sense of immediacy that could be transferred between people and consequently shared within communities. We could use Karen Barads New Materialist theorising, stating that material bodies intra-act on a-deeper-thanmolecular level, and are 'neither individual entities, nor mental impressions, but entangled material practices'. ${ }^{121}$ Barads' theory essentially means that in the nature bodies - or any material objects - have no fixed essence. Rather, they are constantly changing, 'coming-to-be' something that is influenced by everything else. The early modern people did not think in terms of quantum physics, but, on a much more practical level, they understood that the surroundings of people moulded the people, and the people moulded the surroundings. When thought 
in terms of 'coming-to-be', gender and sexed bodies could also refer to maturing and ageing. Especially female corporeality was unstable because of the reproductive life course; the female body transgressed categories, manifested noncompliance to norms and signified decay.

Experience was part of this process: A bodily sensation of touch, or of cold or warmth, of smell or sight, was not necessarily the same for everyone, but there likely was one for almost everyone, or at least almost everyone had some previous experience that allowed them to imagine such sensations. And while not necessarily the same to begin with, these sensations could be assigned meanings that were similar enough to allow people to negotiate a shared interpretation. The body was not only a means of individual experience of faith and gender but also of sharing and negotiating those with other individuals and whole communities. ${ }^{122}$ The body, and the material surroundings, were part of what bridged individuals and communities, and transferred one-time actions into rituals and eventually social structures.

\section{Notes}

1 For women pilgrims, see esp. Craigh, Wandering Women and Morrison, Women Pilgrims.

2 Specht, 'Kulturtradition', pp. 37-46.

3 On Mary, see especially Rubin, Mother of God.

4 Rubin, Mother of God, pp. 243-249; Karant-Nunn, The Reformation of Feeling, p. 164.

5 Caesar of Heisterbach, Dialogus Miraculorum, VII, 34.

6 Caesar of Heisterbach, Dialogus Miraculorum, VI, 30.

7 Vauchez, La Sainteté en Occident, pp. 524-529; Menestò, 'Processo Apostolico', pp. 125-126.

8 Il processo di canonizzazione di Chiara da Montefalco, testis CXXXVI, p. 411.

9 For women saints, see especially Bynum, Holy Feast and Fragmentation and Redemption; Lehmijoki-Gardner, Worldly Saints and Kristillinen mystiikka.

10 Rantala, Gender, Memory and Identity.

11 Bloch, Medieval Misogyny, pp. 98-108.

12 Kelly, Performing Virginity, pp. 3-7; see also Bernau et al., Medieval Virginities; Arnold, 'Labour of Continence', pp. 102-118; Karras, 'Thomas Aquinas's Chastity Belt', pp. 52-67.

13 For different ideas of virginity in the experiences of men and women mystics, see Heinonen, Brides and Knights of Christ.

14 Arnold, 'Labour of Continence', pp. 102-118; Karras, 'Thomas Aquinas's Chastity Belt', pp. 52-67. See also Simons, The Sex of Men, for virility as an element of manliness and social power.

15 Il processo di canonizzazione di Chiara da Montefalco, testis XXXIX, pp. 188-189.

16 Item dixit quod audivit dici frequenter a dicta sancta Clara huiusmodi et similia verba, quod ipsa, antequam perdere suam verginitatem et honestatem, potius vellet in hoc mundo quam diu haberet vivere stare in inferno <et> cum penis infernalibus corporaliter affligi, dummodo non separaretur a Deo'. Il processo di canonizzazione di Chiara da Montefalco, testis XXXIX, p. 168; on crucifix in her heart, articulus CXLIII, p. 22.

17 On Jerome's and Origen's comments, see Tinkle, Gender and Power, p. 23; Brown, The Body and Society, pp. 174, 188, 376.

18 Bynum, Fragmentation and Redemption; Resurrection of the Body, and Christian Materiality, also Biernoff, Sight and Embodiment, pp. 23-37 and de Groot and Morgan, 'Beyond the “Religious Turn”?', pp. 1-29. 
19 UB C 326 ff. 83r-86r.

20 The food-related practices, fasts, communions, and charity of women saints have been researched particularly by Caroline Walker Bynum. Bynum, Holy Feast.

21 Il processo di canonizzazione di Chiara da Montefalco, testis XXXIX, p. 176.

22 Caroline Walker Bynum emphasises suffering as an essential element in the connection formed with Christ's body; this was of particular importance for medieval saints. Bynum, Fragmentation and Redemption, pp. 184, 189. Richard Kieckhefer views patience as a virtuous characteristic especially of the 14th century. Kieckhefer, Unquiet Souls, pp. 50-51.

23 Kieckhefer, Unquiet Souls.

24 Geary, Furta Sacra, p. 10; Lett, 'Deux Hagiographes', pp. 201-216; Lifshitz, 'Beyond Positivism', pp. 95-113; Boesch Gajano, 'Dalla storiografia', pp. 215-233.

25 Amy Hollywood claims that ascetism was not stressed in religious texts written by women themselves until the 14th century. Hollywood, 'Inside Out', p. 82. For the interpretational differences between female saints and male biographers, see also Mooney, 'Imitatio Christi', pp. 52-77 and Scott, 'Mystical Death', pp. 136-167. Catherine of Siena also warned her followers against overly strict asceticism.

26 Elliot, Proving Woman, p. 93; Salmesvuori, Power and Sainthood, pp. 66-70; BlumenfeldKosinsky, The Strange Case of Ermine de Reims, and Mooney, Gendered Voices.

27 For the experiences of late medieval women mystics, see Lehmijoki-Gardner, Kristillinen mystiikka, pp. 281-326.

28 Elliot, Bride of Christ, pp. 177-219; Lowe, 'Secular Brides', pp. 41-65, esp. p. 44. Kate Lowe stresses the subordination of women in both instances: a woman was subordinated either to her husband and his and her families' interests or to the Church; neither sort of bride was consulted regarding her own wishes.

29 McNamer, Affective Meditation, pp. 34-40. Cf., however, see Newman, 'Crucified by the Virtues', pp. 182-209 for Cistercian monks depicting themselves with feminine images, also their soul as Christ's bride.

30 The seminal work in the field is Caroline Walker Bynum's Jesus as Mother. The scholarship on affective religiosity and feminine spirituality has been particularly vast in recent decades. See e.g. McNamer, Affective Meditation; Lindgren, Sensual Encounters; and Bryan, Looking Inward. Cf. Fulton, From Judgment to Passion.

31 Kamerick, Popular Piety and Art, p. 140.

32 Tinkle, Gender and Power, p. 79. See also Corbari, Vernacular Theology, pp. 164-165.

33 Mujica, 'Teresa de Ávila', pp. 30-39.

34 Farmer, 'You Need But Go to Rome', pp. 390-407; Paddock, 'The Imagery of Fire', pp. 91-124.

35 Wiesner-Hanks and Karant-Nunn, Luther on Women, p. 10.

36 Kreitzer, Reforming Mary, pp. 140-141.

37 Rapley, The Dévotes, p. 5; Paddock, 'The Imagery of Fire', pp. 91-124; Evangelisti, 'Religious Women', p. 17.

38 Lehmijoki-Gardner, Worldly Saints.

39 Rapley, The Dévotes, p. 6; Diefendorf, From Penitence to Charity, pp. 101-133; Peake, The Daughters of Charity.

40 See e.g. Kaufmann, 'Pfarrfrau und Publizistin', pp. 169-218; Matheson, Argula von Grumbach; Schütz Zell, Church Mother.

41 Sulkunen, Liisa Eerikintytär.

42 Roper, Holy Household. For Finland's case, see e.g. Einonen and Karonen, Arjen valta and especially Karonen, 'Johdanto', pp. 10-23.

43 Latin sources also use different terms to describe such a situation, e.g. 'obsessus/obsessa, demoniacus/demoniaca, invasatus/invasata a diaboli'.

44 Caesar of Heisterbach, Dialogus Miraculorum, V, p. 11.

45 Several examples of medieval ideas of the Devil's works are included in Caesar of Heisterbach's Dialogue on Miralces in which the whole capitulum five has been dedicated to demons. 'Non potest esse diabolus in anima humana [. . . ] Cum diabolus dicitur esse 
in hominem, non intelligendum est de anima, sed de corpore, quia in concavitatibus eius et in visceribus ubi stercora continentur, et ipse esse potest'. Caesar of Heisterbach, Dialogus Miraculorum, V, p. 15. For examples of a good or evil spirit possessing a body, see Elliot, 'Physiology of Rapture', pp. 141-174.

46 Newman, 'Possessed by the Spirit', pp. 753-762; Caciola, 'Mystics, Demoniacs, and the Physiology of Spirit Possession', pp. 268-306.

47 Katajala-Peltomaa, Demonic Possession and Lived Religion.

48 'Heresy' investigated by inquisitorial methods was a complex and wide category, though. There is an ongoing discussion of the relationship between religious dissent, heresy, and persecution. See e.g. Arnold, Inquisition and Power; Pegg, The Corruption of Angels; Lambert, Medieval Heresy; Moore, Formation of a Persecuting Society, and Ames, Righteous Persecution.

49 Il processo di canonizzazione di Chiara da Montefalco, testis CLX, pp. 434-436.

50 Caciola, Discerning Spirits; Elliott, Proving Woman; Sluhovsky, Believe Not Every Spirit; Levack, The Devil Within.

51 Ames, Righteous Persecution, pp. 23-56.

52 Levack, The Devil Within, p. 195; Stephens, Demon Lovers, pp. 3-11.

53 Boureau, Satan hérétique, pp. 94-100; Russel, Lucifer, pp. 82-86.

54 Cohn, Europe's Inner Demons, p. 225.

55 Cohn, Europe's Inner Demons.

56 The evolution of ideas was not straightforward, and in the mid-15th-century case of Perrinus Hervei, the distinction between possession and madness was not clear, despite the fact that he had invoked demons. The case is cited in Smoller, 'A Case of Demonic Possession', pp. 149-176. See also Smoller, The Saint and the Chopped-Up Baby, pp. 31-33.

57 Olli, 'Devil's Pact' and 'Paholainen on minun veljeni'.

58 Briggs, Witches and Neighbours, pp. 37-31; Purkiss, Witch in History, pp. 145-176; Roper, Witch Craze.

59 Purkiss, Witch in History, p. $145 \mathrm{ff}$.

60 E.g. Trevor-Roper, European Witch-Craze, and several after him.

61 Maxwell-Stuart, 'Contemporary Historical Debate 1400-1750', pp. 11-32; Nenonen, Ihmisen pahuus, pp. 64-91.

62 Lately, the image of witchcraft as a women's holocaust has been repudiated and a more nuanced analysis of gendered features has been achieved. On the historiography, see Nenonen and Toivo, Writing Witch Hunt Histories, and Stephens, Demon Lovers, pp. 3-11. Stephens also links the emergence of witchcraft theory and Protestantism: they were both manifestations of the same crisis of confidence in the efficacy of the sacraments.

63 Cohn, Europe's Inner Demons; Ginzburg, Night Battles, in English 1983. For this discussion, see Nenonen, Ihmisen pahuus, pp. 50-63. For the relationship between Finnish and Swedish folklore and seer cults and notions of Blåkulla, see Östling, Blåkulla, magi och trolldomsprocesser and Eilola, Rajapinnoilla, p. $124 \mathrm{ff}$.

64 Caciola, Discerning Spirits, pp. 172, 254, 309; Elliott, Bride of Christ, pp. 241-265. See also Stephens, Demon Lovers.

65 Caesar of Heisterbach, Dialogus Miraculorum, III 8.

66 'Ut feminae cautae reddantur, quae forte haec quae dicturus sum legent vel audient'. Caesar of Heisterbach, Dialogus Miraculorum, III 6.

67 Cuffel, Gendering Disgust, p. 200.

68 On Nieder's suggestions, see Cameron, Enchanted Europe, p. 112, and Bailey, Fearful Spirits, pp. 209-210.

69 'Non solum in his cavendum est mulieribus sed et viris, quia sicut daemones per formas virorum, ut dictum est, feminas ludificant et corrumpunt, ita per species feminarum viros seducunt et decipiunt'. Caesar of Heisterbach, Dialogus Miraculorum, III 9.

70 Barstow, Witchcraze, p. 84; Roper, Witch Craze, pp. 84-96.

71 Daly, Gyn/Ecology. 
72 Karlsen, The Devil in the Shape of a Woman; Hagen, 'Female Witches', pp. 123-142.

73 Soman, 'The Parliament of Paris', pp. 30-44; Soman, Sorcellerie et justice criminelle; Briggs, Witches and Neighbours, p. 260; Monter, 'Toads And Eucharists', pp. 563-595; Monter, 'Witch Trials in Continental Europe', pp. 12-13 for considerably smaller figures. There are overviews of sex proportions in e.g. Apps and Gow, Male Witches in Early Modern Europe, p. 45; Levack, The Witch-Hunt, p. 142; and Schulte, Man as Witch, p. 71. As these are cited in various other introductory chapters on gender, femininity or masculinity, and witchcraft, we would like to point out that the percentages for Finland and Russia are outdated. For further information, see Toivo, 'Gender, Sex and Cultures', pp. 90, and Muravyeva, 'Russian Witchcraft', p. 124.

74 For European information, see the previous reference. For details on Finland, see Nenonen, 'Witch Trials'; and Tittonen, 'Tuomitaan taikuuden harjoittamisesta', pp. 40-41. The 18th-century figures come from Lahti, Tietäjiä, taikojia, hautausmaita.

75 Nenonen, 'Witch Trials', pp. 373-377; Muravyeva, 'Russian Witchcraft', pp. 109-139.

76 Midelfort, Witch Hunting in South-West Germany.

77 Roper, The Witch Craze, pp. 82-103; See also Roper, The Holy Household.

78 Voltmer, 'Witch-Finders', pp. 74-99; Heuser, 'Die kurkölnischen Hexenprozesse', pp. 133-174. See also Nenonen, 'Historiankirjoittajien paholainen', pp. 131-162, and Toivo, Witchcraft and Gender, p. $78 \mathrm{ff}$.

79 A classic description of the Sabbath and inversion in Clark, 'Inversion, Misrule and the Meaning of Witchcraft', pp. 98-127. Clark, however, did not make the leap to men as witches. For that, see e.g. Dillinger, Evil People, pp. 41-73, esp. pp. 52, 55.

80 SRA, Åbo hovrätt till Kongl Maijt vol. 4. Rotulus Opå de Criminalie saker 1666, 28th May, item 23.

81 SRA, Åbo hovrätt till Kongl Maijt vol. 4. Rotulus Opå de Criminalie saker 1666, 25th Oct, item 43.

82 Åbo hovrätt till Kongl Maijt vol. 4. Rotulus Opå de Criminalie saker 1667, 6th February.

83 Heikkinen, Paholaisen liittolaiset, pp. 204-243.

84 Roper, Witch Craze.

85 'Mijn koo är modstulen, mijn koo är blodstulen, mijn koo är köttstulen, men jagh skall gifwa dig malt och salt, och du skallt få dijn mackt och kraft åther. Och derpå läsa dhe Fadher Wår'. NAF District court record draft Kastelholm 6 August 1666. See also Hausen Bidrag, 266. The court record original mixes what appears to be a direct quotation and a third person indirect narrative (and with them first and singular person pronouns) in a way that suggests that the scribe wished to avoid having to write down the Lord's Prayer.

86 'Du skalt gå efter migh, som fahnen efter dhen orätta mästaren, såsom ock efter dhen som går til tings och weet rätt men witnar orätt'. District Court Record draft, Sund 27 August 1666; Hausen Bidrag, p. 280.

87 'Du skall längtä efter migh som den fattige siäl efter Gudz rijke, och Jorden efter friskt watn'. District court record draft, Sund 27 August 1666; Hausen Bidrag, p. 281. Roughly similar in another testimony against the same woman on Sund 13-14 December 1666; Hausen Bidrag, pp. 288, 289.

88 Clark, Thinking with Demons, pp. 124-133. Important parts of the volume actually consist of work conducted and published as journal articles already during the 1980s and early 1990s. See e.g. Clark, 'The Gendering of Witchcraft in French Demonology', pp. 426-437.

89 Apps and Gow, Male Witches, p. 136.

90 Opitz-Belakhal, Das Universum des Jean Bodin, pp. 131-167.

91 Rowlands, 'Witchcraft and Gender', pp. 449-467; Kallestrup 'The Infected', pp. 233254; Kallestrup, 'Kind in Words', pp. 137-153.

92 Brauner, Fearless Wives and Frightened Shews; Wiesner-Hanks, Witchcraft in Early Modern Europe; Schulte, Man as Witch. 
93 Toivo, 'Witchcraft and Gender' or Rowlands 'Witchcraft and Gender' and further citations in both. On demonological theories and thinking, see various articles in Goodare, Voltmer and Willumsen, Demonology and Witch-Hunting.

94 The healer witch theories referred to here and originating in the 1970s stem from the same source, the most well-known advocate of which was probably Echrenreich and English, Witches, Midwives and Nurses. In Germany, Rowlands 'Witchcraft and old women'; in the Netherlands, de Blécourt, 'Evil People'; and in Sweden, Oja, 'Kvinnligt, manligt'.

95 For Finnish folklore and casting a spell on harnesses, see Stark-Arola, Magic, Body and Social Order, p. $203 \mathrm{ff}$.

96 Nenonen, Noituus, taikuus ja noitavainot, pp. 72-85, 346-372, and 'Noituus ja Idän mies', pp. 131-162; Ulvila 4-5 November 1695. Vehmaa ja Ala-Satakunta II, KO a 5:367-368. NAF.

97 Examples about cattle magic abound: Ulvila 13-16 February 1704. Vehmaa ja AlaSatakunta II KO a 20: 346-352. NAF. For magic resembling stealing, e.g. Ulvila 19-20 January 1675. Bielkesamlingen vol. 27:16-17 and Ulvila 11-12 September 1676. Bielkesamlingen vol. 27:53-54v. SRA. See also e.g. Eilola, Rajapinnoilla, p. 68.

98 See e.g. de Blécourt, 'Evil People', and Davies, Cunning Folk.

99 Bynum, Holy Feast.

100 McNamer, Affective Meditation, pp. 119-148.

101 Karant-Nunn, The Reformation of Feeling, p. 185.

102 See analyses on Luther's experiences in Roper, Martin Luther. For descriptions of the Luther Cult, see e.g. Scribner, 'Incombustible Luther', pp. 38-68.

103 Huittinen 4-5 June 1646. Ala-Satakunta I KO a 6, 148. NAF. See also Toivo, 'Religion and Emotion', pp. 289-305.

104 Appropriating terminology from Reddy, The Navigation of Feeling. See also Plamper, 'History of Emotions', pp. 237-265.

105 Van Gent, Magic, Body, $127 \mathrm{ff}$.

106 See e.g. Purkiss, The Witch in History, pp. 91-117; Eilola, Rajapinnoilla.

107 Heal, 'Sacred Image and Sacred Space', pp. 39-59; Burnett, 'Social History of Communion', pp. 77-119, esp. pp. 87-88; Karant-Nunn, The Reformation of Ritual, pp. 116-120.

108 Kuuliala, 'Disability and Religious Practices', pp. 46-74.

109 Bynum, Fragmentation and Redemption.

110 Van Gent, Magic, Body, $127 \mathrm{ff}$.

111 McNamer, Affective Meditation, p. 7.

112 Hendrix and Karant-Nunn, Masculinity in the Reformation Era.

113 See e.g. the material in Toivo, Faith and Magic and 'Protestantism, Modernity and the Power of Penetration', pp. 75-103.

114 For the role of communion mysticism in strengthening the clergy, see Bynum, Holy Feast. For the support offered to sacred places determined by clergy(men), see Morrison, Women Pilgrims.

115 Luther, 'On the Magnificat', pp. 295-358. The same can be found concerning theology in Finland in, e.g. Ericus Erici Sorolainen's 'Sermon on the 1st Sunday after Christmas' in his Postilla. For similar interpretations, see also, e.g. Mack, 'Religion, Feminism, and the Problem of Agency', pp. 434-459; McNamer, Affective Meditation, pp. 119-148, or Bynum, Holy Feast.

116 Newman, 'Crucified by Their Virtues', pp. 182-209.

117 Mack, 'Religion, Feminism, and the Problem of Agency'; see also Mahmood, Politics of Piety.

118 Butler, Gender Trouble, pp. 45-49, 163-171, 177-178.

119 Bynum, Holy Feast; Protestant examples are discussed e.g. in Matheson, Argula von Grumbach; Mikkola, 'Esikuvallinen uskonsisar', 41-69.

120 Holloway, 'Make Believe', pp. 1961-1974, esp. p. 1963; id., 'Enchanted Spaces', pp. 182-187; Gökarıksel, 'Beyond the Officially Sacred', pp. 657-674.

121 Barad, Meeting the Universe, 55f.

122 See also Mahmood, Politics of Piety and Ahmed, 'Some Preliminary Remarks'. 


\section{Bibliography}

\section{Unprinted source material}

Riksarkiv, Sweden/Stockholm (SRA).

Åbo Hovrätt till Kongl Maijt, vols. 2-4.

Bielkesamlingen: Gustaf Horns och Sigred Bielkes gods- och länshandlingar. Finland.

Björneborgs grefskap, domböcker 1670-1678, vols. 26-27;

The National Archives, Helsinki, Finland (NAF).

Rural District Court Records: Ala-Satakunta I - II; Vehmaa ja Ala-Satakunta I - II.

Uppsala University Library (UB): C 326

\section{Printed source material}

Caesar of Heisterbach. Dialogus Miraculorum, edited by Joseph Strange. Ridgewood: The Gregg Press Inc., 1966 (1851).

Hausen, Renhold (1894-1898). Bidrag till Finlands historia II. Helsinki: The National Archives.

Il processo di canonizzazione di Chiara da Montefalco, edited by Enrico Menestò. Spoleto: Centro italiano di Studi sull'alto medioevo, 1991.

Luther, Martin. 'On the Magnificat'. In Luther's Works, the American Edition, edited by Jaroslav J. Pelikan and Helmut Lehmann, 295-358, 55 vols. St. Louis and Philadelphia: CPH \& Fortress Press, 1955-1986.

Schütz Zell, Katharina. Church Mother: The Writings of a Protestant Reformer in SixteenthCentury Germany. Edited and translated by Elsie McKee. Chicago and London: University of Chicago Press, 2006.

Sorolainen, Ericus Erici. Postilla I-II. Stockholm: Ch. Reusner, 1621-1625.

\section{Literature}

Ahmed, Sara. 'Some Preliminary Remarks on the Founding Gestures of the New Materialism'. European Journal of Women's Studies 15 (2008): 23-39.

Ames, Christine Caldwell. Righteous Persecution: Inquisition, Dominicans, and Christianity in the Middle Ages. Philadelphia: University of Pennsylvania Press, 2009.

Apps, Lara, and Andrew Gow. Male Witches in Early Modern Europe. Manchester: Manchester University Press, 2003.

Arnold, John. Inquisition and Power: Catharism and the Confessing Subject in Medieval Languedoc. Philadelphia: University of Pennsylvania Press, 2001.

Arnold, John. 'The Labour of Continence: Masculinity and Clerical Virginity'. In Medieval Virginities, edited by Anke Bernau, Ruth Evans, and Sarah Salih, 102-118. Toronto and Buffalo: University of Toronto Press, 2003.

Bailey, Michael D. Fearful Spirits, Reasoned Follies: The Boundaries of Superstition in Late Medieval Europe. Ithaca and London: Cornell University Press, 2013.

Barad, Karen. Meeting the Universe Halfway - Quantum Physics and the Entanglement of Matter and Meaning. Durham: Duke University Press, 2007.

Barstow, Ann Llewellyn. The Witchcraze: A New History of the European Witch Hunts. London: Pandora, 1995 (1994).

Bernau, Anke, Ruth Evans, and Sarah Salih (eds). Medieval Virginities. Toronto: University of Toronto Press, 2003. 
Biernoff, Suzannah. Sight and Embodiment in the Middle Ages. Houndsmills: Palgrave McMillan, 2002.

Bloch, Howard R. Medieval Misogyny and the Invention of Western Romantic Love. Chicago and London: University of Chicago Press, 1991.

Blumenfeld-Kosinski, Renate. The Strange Case of Ermine de Reims: A Medieval Woman Between Demons and Saints. Philadelphia: University of Pennsylvania Press, 2015.

Boesch Gajano, Sofia. 'Dalla storiografia alla storia'. In Miracoli. Dai Segni alla storia, edited by Sofia Boesch Gajano and Marilena Modica, 215-233. Rome: Viella, 2000.

Boureau, Alain. Satan hérétique. Histoire de la démonologie dans l'Occident médiévale (12801330). Paris: Odile Jacob, 2003.

Brauner, Sigrid. Fearless Wives and Frightened Shrews: The Construction of the Witch in Early Modern Germany. Amherst: University of Massachusetts Press, 1994.

Briggs, Robin. Witches and Neighbours: The Social and Cultural Context of European Witchcraft. London: HarperCollins Publishers, 1996.

Brown, Peter. The Body and Society: Men, Women, and Sexual Renunciation in Early Christianity. New York: Columbia University Press, 1988.

Bryan, Jennifer. Looking Inward: Devotional Reading and the Private Self in Late Medieval England. Philadelphia: University of Pennsylvania Press, 2008.

Burnett, Amy Nelson. 'The Social History of Communion'. Past and Present 211 (2011): 77-119.

Butler, Judith. Gender Trouble: Feminism and the Subversion of Identity. New York: Routledge, 1990.

Bynum, Caroline Walker. Jesus as Mother: Studies in the Spirituality of the High Middle Ages. Berkeley: University of California Press, 1982.

Bynum, Caroline Walker. Holy Feast and Holy Fast: The Religious Significance of Food to Medieval Women. Berkeley: University of California Press, 1987.

Bynum, Caroline Walker. Fragmentation and Redemption: Essays on Gender and the Human Body in Medieval Religion. New York: Zone Books, 1991.

Bynum, Caroline Walker. The Resurrection of the Body in Western Christianity, 200-1336. New York: Columbia University Press, 1995.

Bynum, Caroline Walker. Christian Materiality: An Essay on Religion in the Late Medieval West. New York: Zone Books, 2011.

Caciola, Nancy. 'Mystics, Demoniacs, and the Physiology of Spirit Possession in Medieval Europe'. Comparative Studies in Society and History 42, no. 2 (2000): 268-306.

Caciola, Nancy. Discerning Spirits: Divine and Demonic Possession in the Middle Ages. Ithaca: Cornell University Press, 2003.

Cameron, Euan. Enchanted Europe: Superstition, Reason, and Religion, 1250-1750. Oxford: Oxford University Press, 2010.

Clark, Stuart. 'Inversion, Misrule and the Meaning of Witchcraft'. Past and Present 87 (1980): 98-127.

Clark, Stuart. 'The Gendering of Witchcraft in French Demonology: Misogyny or Polarity?'. French History 5 (1991): 426-437.

Clark, Stuart. Thinking with Demons. Oxford: Oxford University Press, 1997.

Cohn, Norman. Europe's Inner Demons: An Enquiry Inspired by the Great Witch-Hunt. New York: Basic Books, 1975.

Corbari, Eliana. Vernacular Theology: Dominican Sermons and Audience in Late Medieval Italy. Berlin and Boston: Walter de Gruyter, 2013.

Cuffel, Alexandra. Gendering Disgust in Medieval Religious Polemic. Notre Dame: University of Notre Dame Press, 2007.

Daly, Mary. Gyn/Ecology: The Metaethics of Radical Feminism. Boston: Beacon Press, 1978. 
Davies, Owen. Cunning Folk. Manchester: Manchester University Press, 2003.

de Blécourt, Willem. "Evil People”: A Late Eighteenth-century Dutch Witch Doctor and His Clients'. In Beyond the Witch Trials: Witchcraft and Magic in Enlightenment Europe, edited by Owen Davies and Willem de Blécourt, 144-166. Manchester: Manchester University Press, 2004.

de Groot, Joanna, and Sue Morgan. 'Introduction: Beyond the "Religious Turn"? Past, Present and Future Perspectives in Gender History'. In Sex, Gender and the Sacred: Reconfiguring Religion in Gender History, edited by Joanna de Groot and Sue Morgan, 1-29. Oxford: John Wiley \& Sons, 2014.

Diefendorf, Barbara. From Penitence to Charity: Pious Women and the Catholic Reformation in Paris. New York: Oxford University Press, 2004.

Dillinger, Johannes. 'Evil People': A Comparative Study of Witch Hunts in Swabian Austria and the Electorate of Trier. Charlottesville: University of Virginia Press, 2009.

Echrenreich, Barbara, and Deirdre English. Witches, Midwives and Nurses: A History of Women Healers. New York: The Feminist Press, 1973.

Eilola, Jari. Rajapinnoilla: Sallitun ja kielletyn määritteleminen 1600-luvun jälkipuoliskon noituusja taikuutapauksissa. Bibliotheca Historica 81. Helsinki: Finnish Literature Society, 2003. [On the Borderlines: Boundaries Between the Accepted and the Forbidden in Finnish and Swedish Witchcraft and Magic Cases in the Latter Half of the Seventeenth Century.]

Einonen, Pia, and Petri Karonen (eds). Arjen Valta. Suomalaisen yhteiskunnan patriarkaalisesta järjestyksestä myöhäiskeskiajalta teollistumisen kynnykselle v. 1450-1860. Helsinki: Finnish Literature Society, 2002.

Elliott, Dyan. 'The Physiology of Rapture and Female Spirituality'. In Medieval Theology and the Natural Body, edited by Peter Biller and A. J. Minnis, 141-174. Bury St Edmunds: York Medieval Press, 1997.

Elliott, Dyan. Proving Woman: Female Spirituality and Inquisitional Culture in the Later Middle Ages. Princeton: Princeton University Press, 2004.

Elliott, Dyan. Bride of Christ Goes to Hell: Metaphor and Embodiment in the Lives of Pious Women, 200-1500. Philadelphia: University of Pennsylvania Press, 2012.

Evangelisti, Silvia. 'Religious Women, Mystic Journeys and Ageing in Early Modern Spain'. Journal of Early Modern History 22, no. 1-2 (2018): 9-27.

Farmer, Julia. "'You Need But Go to Rome": Teresa of Avila and the Text/image Powerplay'. Women's Studies 42, no. 4 (2016): 390-407. https://doi.org/10.1080/0049787 8.2013.772865.

Fulton, Rachel. From Judgment to Passion: Devotion to Christ and the Virgin Mary. New York: Columbia University Press, 2002.

Geary, Patrick. Furta Sacra: Thefts of Relics in the Central Middle Ages. Princeton: Princeton University Press, 1978.

Ginzburg, Carlo. The Night Battles: Witchcraft and Agrarian Cults in the Sixteenth and Seventeenth Centuries. Baltimore: The Johns Hopkins University Press, 1992 (Italian Original 1966).

Goodare, Julian, Voltmer, Rita and Willumsen, Liv Helene. Demonology and Witch-Hunting in Early Modern Europe. London: Routledge, 2020.

Gökarıksel, Banu. 'Beyond the Officially Sacred: Religion, Secularism, and the Body in the Production of Subjectivity'. Social \& Cultural Geography 10, no. 6 (2009): 657-674.

Hagen, Rune Blix. 'Female Witches and Sami Sorcerers in the Witch Trials of Arctic Norway (1593-1695)'. ARV Nordic Yearbook of Folklore 62 (2006): 123-142.

Heal, Bridget. 'Sacred Image and Sacred Space in Lutheran Germany'. In Sacred Space in Early Modern Europe, edited by Will Coster and Andrew Spicer, 39-59. Cambridge: Cambridge University Press, 2005. 
Heikkinen, Antero. Paholaisen liittolaiset. Noita- ja magiakäsityksiä ja -oikeudenkäyntejä Suomessa 1600-luvun jälkipuoliskolla (n. 1640-1712). Historiallisia tutkimuksia LXXVIII. Helsinki: Suomen Historiallinen Seura, 1969.

Heinonen, Meri. 'Brides and Knights of Christ: Gender and Body in Later Medieval German Mysticism'. Ph.D. diss. University of Turku, 2007.

Hendrix, Scott H., and Susan C. Karant-Nunn (eds). Masculinity in the Reformation Era. Kirksville: Truman State University Press, 2008.

Heuser, Peter. 'Die kurkölnischen Hexenprozesse des 16. und 17. Jahrhunderts in geschlechtergeschichtlicher Perspektive'. In Geschlecht, Magie und Hexenverfolgung, edited by Ingrid Ahrendt-Schulte, Dieter R. Bauer, Sönke Lorenz, and Jürgen Michael Schmidt, 133-174. Hexenforschung Band 7. Bielefeld: Verlag für Regionalgeschichte, 2002.

Holloway, Julian. 'Make-believe: Spiritual Practice, Embodiment and Sacred Space'. Environment and Planning A: Economy and Space 35, no. 11 (2003): 1961-1974. https:// doi.org/10.1068/a3586.

Holloway, Julian. 'Enchanted Spaces: The Séance, Affect, and Geographies of Religion'. Annals of the Association of American Geographers 96, no. 1 (2006): 182-187.

Hollywood, Amy. 'Inside Out: Beatrice of Nazareth and Her Hagiographer'. In Gendered Voices: Medieval Saints and Their Interpreters, edited by Catherine M. Mooney, 78-98. Philadelphia: University of Pennsylvania Press, 1999.

Kallestrup, Louise Nyholm. 'The Infected and the Guilty: On Heresy and Witchcraft in Post-Reformation Denmark'. In Contesting Orthodoxy in Medieval and Early Modern Europe: Heresy, Magic and Witchcraft, edited by Louise Nyholm Kallestrup and Raisa Maria Toivo, 233-254. London: Palgrave Macmillan, 2017.

Kallestrup, Louise Nyholm. "Kind in Words and Deeds, But False in Their Hearts": Fear of Evil Conspiracy in Late-Sixteenth-Century Denmark'. In Cultures of Witchcraft in Europe from the Middle Ages to the Present, edited by Jonathan Barry, Owen Davies, and Cornelie Usborne, 137-153. Cham: Springer International Publishing, 2018.

Kamerick, Kathleen. Popular Piety and Art in the Late Middle Ages: Image Worship and Idolatry in England, 1350-1500. New York: Palgrave, 2002.

Karant-Nunn, Susan. The Reformation of Ritual: An Interpretation of Early Modern Germany. London: Routledge, 2007 (1997).

Karant-Nunn, Susan. The Reformation of Feeling: Shaping the Religious Emotions in Early Modern Germany. New York: Oxford University Press, 2010.

Karlsen, Carol F. The Devil in the Shape of a Woman: Witchcraft in Colonial New England. New York: Vintage Book, 1989 (1987).

Karonen, Petri. 'Johdanto: Moninainen Patriarkaalisuus'. In Arjen Valta. Suomalaisen yhteiskunnan patriarkaalisesta järjestyksestä myöhäiskeskiajalta teollistumisen kynnykselle $v$. 1450-1860, edited by Pia Einonen and Petri Karonen, 10-23. Helsinki: Finnish Literature Society, 2002.

Karras, Ruth Mazo. 'Thomas Aquinas's Chastity Belt: Clerical Masculinity in Medieval Europe'. In Gender and Christianity in Medieval Europe: New Perspectives, edited by Lisa M. Bitel and Felice Lifshitz, 52-67. Philadelphia: University of Pennsylvania Press, 2008.

Katajala-Peltomaa, Sari. Demonic Possession and Lived Religion in Later Medieval Europe. Oxford: Oxford University Press, 2020.

Kaufmann, Thomas. 'Pfarrfrau und Publizistin: Das Reformatorische "Amt" der Katharina Zell'. Zeitschrift für Historische Forschung 23 (1996): 169-218.

Kelly, Kathleen Coyne. Performing Virginity and Testing Chastity in the Middle Ages. London: Routledge, 2000. 
Kieckhefer, Richard. Unquiet Souls: Fourteenth-Century Saints and Their Religious Milieu. Chicago and London: University of Chicago Press, 1987 (1984).

Kreitzer, Beth. Reforming Mary: Changing Images of the Virgin Mary in Lutheran Sermons of the Sixteenth Century. New York: Oxford University Press, 2004.

Kuuliala, Jenni. 'Disability and Religious Practices in Late Medieval Prussia: Infirmity and the Miraculous in the Canonization Process of St. Dorothea of Montau (14041406)'. In Lived Religion and the Long Reformation in Northern Europe. c. 1300-1700, edited by Sari Katajala-Peltomaa and Raisa Maria Toivo, 46-74. Leiden: Brill, 2017.

Lahti, Emmi. Tietäjiä, taikojia, hautausmaita. Taikuus Suomessa 1700-luvun jälkipuoliskolla. Jyväskylä studies in humanities. Jyväskylä: University of Jyväskylä, 2016. [Cunning Folk, Practitioners of Magic and Cemeteries: Magic in Late 18th Century Finland]. http://urn.fi/URN:ISBN:978-951-39-6466-5.

Lambert, Malcolm. Medieval Heresy: Popular Movements from the Gregorian Reform to the Reformation. Oxford: Blackwell, 2002.

Lehmijoki-Gardner, Maiju. Worldly Saints: Social Interaction of Dominican Penitent Women in Italy, 1200-1500. Helsinki: Suomen Historiallinen Seura, 1999.

Lehmijoki-Gardner, Maiju. Kristillinen mystiikka. Läntinen perinne antiikista uudelle ajalle. Helsinki: Kirjapaja, 2007.

Lett, Didier. 'Deux hagiographes, un saint et un roi. Conformisme et créativité dans les deux recueils de miracula de Thomas Becket'. In Auctor et auctoritas: invention et conformisme dans l'écriture médiévale. Actes du colloque de Saint-Quentin-en Yvelines (14-15 juin 1999), edited by Michael Zimmermann, 201-216. Paris: Ecole des chartes, 2001.

Levack, Brian. The Witch-Hunt in Early Modern Europe. London: Pearson, 2006.

Levack, Brian. The Devil Within: Possession E Exorcism in the Christian West. New Haven: Yale University Press, 2013.

Lifshitz, Felice. 'Beyond Positivism and Genre: "Hagiographical" Texts as Historical Narrative'. Viator 25 (1994): 96-113.

Lindgren, Erika Lauren. Sensual Encounters: Monastic Women and Spirituality in Medieval Germany. New York: Columbia University Press, 2009.

Lowe, Kate. 'Secular Brides and Convent Brides: Wedding Ceremonies in Italy During the Renaissance and Counter-Reformation'. In Marriage in Italy 1300-1650, edited by Trevor Dean and K. J. P. Lowe, 41-65. Cambridge: Cambridge University Press, 1998.

Mack, Phyllis. 'Religion, Feminism, and the Problem of Agency: Reflections on Eighteenth-Century Quakerism'. In Women, Gender and Enlightenment, edited by Sarah Knott and Barbara Taylor, 434-459. Basingstoke: Palgrave Macmillan, 2005.

Mahmood, Saba. Politics of Piety: The Islamic Revival and the Feminist Subject. Princeton: Princeton University Press, 2005.

Matheson, Peter (ed.). Argula von Grumbach: A Woman's Voice in the Reformation. Edinburgh: Clark, 1995.

Maxwell-Stuart, Peter. 'The Contemporary Historical Debate 1400-1750'. In Witchcraft Historiography, edited by Owen Davies and Jonathan Barry, 11-32. Basingstoke: Palgrave Macmillan, 2007.

McNamer, Sarah. Affective Meditation and the Invention of Medieval Compassion. Philadelphia: University of Pennsylvania Press, 2010.

Menestò, Enrico. 'Il Processo apostolico per la canonizzazione di Chiara da Montefalco (1318-1319)'. In Mistiche e devote nell'Italia tardomedievale, edited by Daniel Bornstein and Roberto Rusconi, 107-126. Napoli: Liguori Editore, 1992.

Midelfort, H. C. Erik. Witch Hunting in South-West Germany, 1562-1684. Stanford: Stanford University Press, 1972. 
Mikkola, Sini. 'Esikuvallinen uskonsisar: Sukupuolen merkitys Martin Lutherin käsityksessä Argula von Grumbachista reformaation edistäjänä'. In Reformaatio 500 vuotta. Suomen kirkkohistoriallisen seuran vuosikirja 2016, edited by Piia Latvala and Olli Lampinen-Enqvist, 41-69. Helsinki: Suomen kirkkohistoriallinen seura, 2016.

Monter, William. 'Toads and Eucharists: The Male Witches of Normandy 1564-1666'. French Historical Studies 20, no. 4 (1997): 563-595. https://doi.org/10.2307/286912.

Monter, William. 'Witch Trials in Continental Europe 1560-1660'. In Witchcraft and Magic in Europe: The Period of the Witch Trials, edited by Bengt Ankarloo, Stuart Clark, and William Monter, 1-52. London: The Athlone Press, 2002.

Mooney, Catherine (ed.). Gendered Voices: Medieval Saints and Their Interpreters. Philadelphia: University of Pennsylvania Press, 1999.

Mooney, Catherine. 'Imitatio Christi or Imitatio Mariae? Clare of Assisi and Her Interpreters'. In Gendered Voices: Medieval Saints and Their Interpreters, edited by Catherine M. Mooney, 52-77. Philadelphia: University of Pennsylvania Press, 1999.

Moore, R. I. The Formation of a Persecuting Society: Authority and Deviance in Western Europe 950-1250. Oxford: Blackwell, 2007.

Morrison, Susan Signe. Women Pilgrims in Late Medieval England: Private Piety as Public Performance. London and New York: Routledge, 2000.

Mujica, Barbara. 'Teresa de Ávila: Portrait of the Saint as a Young Woman'. Romance Quarterly 63, no. 1 (2016): 30-39.

Muravyeva, Marianna G. 'Russian Witchcraft on Trial: Historiography and Methodology for Studying Russian Witches'. In Writing Witch-Hunt Histories: Challenging the Paradigm, edited by Marko Nenonen and Raisa Maria Toivo, 109-139. Leiden: Brill, 2014.

Nenonen, Marko. Noituus, taikuus ja noitavainot Ala-Satakunnan, Pohjois-Pohjanmaan ja Viipurin Karjalan maaseudulla 1620-1700. Helsinki: Finnish Literature Society, 1992.

Nenonen, Marko. 'Noituus ja Idän mies. Noitavainojen erityisluonne Viipurin Karjalassa'. In Manaajista maalaisaateliin. Tulkintoja toisesta historian, antropologian ja maantieteen välimaastossa, edited by Kimmo Katajala, 131-162. Tietolipas 140. Helsinki: Finnish Literature Society, 1995.

Nenonen, Marko. 'Historiankirjoittajien paholainen. Noitavainojen uusi kuva'. In Paholainen, noituus ja magia - kristinuskon kääntöpuoli. Pahuuden kuvasto vanhassa maailmassa, edited by Sari Katajala-Peltomaa and Raisa Maria Toivo, 244-299. Tietolipas 203. Helsinki: Finnish Literature Society, 2004.

Nenonen, Marko. 'Finland: Witch Trials'. In Encyclopedia of Witchcraft: The Western Tradition, edited by Richard M. Golden, 373-377, vol. 2. Santa Barbara: ABC-CLIO, 2006.

Nenonen, Marko. Noitavainot Euroopassa. Ihmisen Pahuus. Jyväskylä: Atena, 2007.

Nenonen, Marko, and Raisa Maria Toivo (eds). Writing Witch Hunt Histories. Leiden: Brill, 2013.

Newman, Barbara. 'Possessed by the Spirit: Devout Women, Demoniacs, and the Apostolic Life in the Thirteenth Century'. Speculum 73 (1998): 733-770.

Newman, Martha G. 'Crucified by the Virtues: Monks, Lay Brothers, and Women in Thirteenth-Century Cistercian Saints' Lives'. In Gender and Difference in the Middle Ages, edited by Sharon Farmer and Carol Braun Pasternack, 182-209. Minneapolis: University of Minnesota Press, 2003.

Oja, Linda. 'Kvinnligt, Manligt, Magiskt. Genusperspektiv på folklig magi i 1600- och 1700-Talets Sverige'. Kyrkohistorisk årskrift (1994): 43-55.

Olli, Soili Maria. 'The Devil's Pact: A Male Strategy'. In Beyond the Witch Trials: Witchcraft and Magic in Enlightenment Europe, edited by Owen Davies and Willem de Blécourt, 100-116. Manchester: Manchester University Press, 2004. 
Olli, Soili Maria. “'Paholainen on minun veljeni”. Kirkon ja kansan Paholaiskuva uuden ajan alussa'. In Paholainen, noituus ja magia - kristinuskon kääntöpuoli. Pahuuden kuvasto vanhassa maailmassa, edited by Sari Katajala-Peltomaa and Raisa Maria Toivo. Tietolipas 203. Helsinki: Finnish Literature Society, 2004.

Opitz-Belakhal, Claudia. Das Universum des Jean Bodin. Staats-Bildung, Macht un Geslecht im 16. Jahrhundert. Frankfurt: Campus, 2006.

Östling, Per Anders. Blåkulla, magi och Trolldomsprocesser. En etnologisk studie av folkliga trosförestälningar och av trolldomsprocesserna inom Svea Hovrätts jurisdiktion 1597-1720. Etnolore 25. Uppsala: Uppsala Universitet, 2002.

Paddock, John. 'The Imagery of Fire, Water and Marriage in Saint Teresa of Avila'. Bulletin of Spanish Studies 92, no. 8-10 (2015): 91-124.

Peake, Rose-Marie. 'The Daughters of Charity and Moral Management in SeventeenthCentury France: Creating Conservative Catholics, Securing Survival'. Unpublished Ph.D. diss. Helsinki: University of Helsinki, 2015.

Pegg, Mark Gregory. The Corruption of Angels: The Great Inquisition of 1245-1246. Princeton: Princeton University Press, 2001.

Plamper, Jan. 'The History of Emotions: An Interview with William Reddy, Barbara Rosenwein, and Peter Stearns'. History and Theory 49, no. 2 (2010): 237-265.

Purkiss, Diane. The Witch in History: Early Modern and Twentieth Century Representations. London and New York: Routledge, 1996.

Rantala, Jussi (ed.). Gender, Memory, and Identity in the Roman World. Amsterdam: Amsterdam University Press, 2019.

Rapley, Elisabeth. The Dévotes: Women and Church in Seventeenth-Century France. Montreal: McGill-Queen's University Press, 1990.

Reddy, William. The Navigation of Feeling: A Framework for the History of Emotions. Cambridge: Cambridge University Press, 2001.

Roper, Lyndal. The Holy Household: Women and Morals in Reformation Augsburg. Oxford: Clarendon Press, 1989.

Roper, Lyndal. The Witch Craze: Terror and Fantasy in Baroque Germany. New Haven: Yale University Press, 2004.

Roper, Lyndal. Martin Luther: Renegade and Prophet. London: Bodley Head, 2016.

Rowlands, Alison. 'Witchcraft and Old Women in Early Modern Germany'. Past and Present 173 (2001): 50-89.

Rowlands, Alison. Witchcraft Narratives in Germany Rothenburg, 1561-1652. Manchester: Manchester University Press, 2003.

Rowlands, Alison. 'Witchcraft and Gender in Early Modern Europe'. In The Oxford Handbook of Witchcraft in Early Modern Europe and Colonial America, edited by Brian P. Levack, 449-467. Oxford: Oxford University Press, 2013.

Rubin, Miri. Mother of God: A History of the Virgin Mary. New Haven: Yale University Press, 2009.

Russel, Jeffrey Burton. Lucifer: The Devil in the Middle Ages. Ithaca: Cornell University Press, 1984.

Salmesvuori, Päivi. Power and Sainthood: The Case of Birgitta of Sweden. New York: Palgrave McMillan, 2014.

Schulte, Rolf. Man as Witch: Male Witches in Central Europe. Houndsmills: Palgrave, 2009.

Scott, Karen. 'Mystical Death, Bodily Death: Catherine of Siena and Raymond of Capua on the Mystic's Encounter with God'. In Gendered Voices: Medieval Saints and Their Interpreters, edited by Catherine Mooney, 136-167. Philadelphia: University of Pennsylvania Press, 1999. 
Scribner, Robert. 'Incombustible Luther: The Image of the Reformer in Early Modern Germany'. Past and Present 110 (1986): 38-68.

Simons, Patricia. The Sex of Men in Premodern Europe: A Cultural History. Cambridge: Cambridge University Press, 2011.

Sluhovsky, Moshe. Believe Not Every Spirit: Possession, Mysticism, E Discernment in Early Modern Catholicism. Chicago: University of Chicago Press, 2008.

Smoller, Laura Ackerman. 'A Case of Demonic Possession in Fifteenth-Century Brittany: Perrine Hervé and the Nascent Cult of Vincent Ferrer'. In Voices from the Bench: The Narratives of Lesser Folk in Medieval Trials, edited by Michael Goodich, 149-176. Houndsmills: Palgrave Macmillan, 2006.

Smoller, Laura Ackerman. The Saint and the Chopped-Up Baby: The Cult of Vincent Ferrer in Medieval and Early Modern Europe. Ithaca: Cornell University Press, 2014.

Soman, Alfred. 'The Parlement of Paris and the Great Witch Hunt (1565-1640)'. Sixteenth Century Journal 9, no. 2 (1978): 30-44. https://doi.org/10.2307/2539661.

Soman, Alfred. Sorcellerie et justice criminelle. Le parlement de Paris (16e-18e siècles). Aldershot: Variorum, 1992.

Specht, Edith. 'Kulturtradition einer weiblichen Gottheit: Beispiel Ephesos'. In Maria, Abbild oder Vorbild? Zur Sozialgeschichte mittelalterlicher Marienverehrung, edited by Hedwig Röckelein, Claudia Opitz, and Dieter R. Bauer, 37-46. Tübingen: Edition Diskord cop., 1990.

Stark-Arola, Laura. Magic, Body and Social Order: The Construction of Gender Through Women's Private Rituals in Traditional Finland. Studia Fennica Folkloristica 5. Helsinki: Finnish Literature Society, 1998.

Stephens, Walter. Demon Lovers: Witchcraft, Sex, and the Crisis of Belief. Chicago: University of Chicago Press, 2002.

Sulkunen, Irma. Liisa Eerikintytär ja hurmosliikkeet 1700-1800-luvulla. Helsinki: Hanki ja Jää, 1999.

Tinkle, Theresa. Gender and Power in Medieval Exegesis. New York: Palgrave McMillan, 2010.

Tittonen, Emmi. ““Tuomitaan taikuuden harjoittamisesta”. Taikuusoikeudenkäynti 1700luvun lopun Pohjois-Pohjanmaalla ja Kainuussa'. MA thesis in Finnish History. University of Jyväskylä, 2007. http://urn.fi/URN:NBN:fi:jyu-2007623.

Toivo, Raisa Maria. Witchcraft and Gender in Early Modern Europe: Finland and the Wider European Experience. Aldershot: Ashgate, 2008.

Toivo, Raisa Maria. 'Gender, Sex and Cultures of Trouble in Witchcraft Studies: European Historiography with Special Reference to Finland'. In Writing Witch-Hunt Histories: Challenging the Paradigm, edited by Marko Nenonen and Raisa Maria Toivo, 87-108. Leiden: Brill, 2014.

Toivo, Raisa Maria. Faith and Magic in Early Modern Finland. Basingstoke: Palgrave Macmillan, 2016.

Toivo, Raisa Maria. 'Religion and Emotion: Rosaries as Objects and the Associated Emotions in 17th Century Finland'. Scandinavian Journal of History 41, no. 3 (2016): 289-305.

Toivo, Raisa Maria. 'Protestantism, Modernity and the Power of Penetration: Saints and Sacrifice in 17th Century Lutheran Finland'. In Lived Religion and the Long Reformation in Northern Europe c. 1300-1700, edited by Sari Katajala-Peltomaa and Raisa Maria Toivo, 75-103. Leiden: Brill, 2017.

Toivo, Raisa Maria. 'Witchcraft and Gender'. In The Routledge History of Witchcraft, edited by Johannes Dillinger. London: Routledge, 2020. 
142 Spirituality, sinfulness and gender

Trevor-Roper, Hugh. The European Witch-Craze of the 16th and 17th Centuries. New York: Harper \& Row, 1969.

Van Gent, Jacqueline. Magic, Body and the Self in Eighteenth-Century Sweden. Leiden: Brill, 2009.

Vauchez, André. La Sainteté en Occident aux derniers siècles du Moyen Âge. D'après les procès de canonisation et les documents hagiographiques. Rome: École française de Rome, 1988 (1981).

Voltmer, Rita. 'Witch-Finders, Witch-Hunter of Kings of the Sabbath? The Prominent Role of Men in the Mass Persecutions of the Rhine-Meuse Area (Sixteenth-Seventeenth Centuries)'. In Witchcraft and Masculinities in Early Modern Europe, edited by Alison Rowlands, 74-99. Houndsmill: Palgrave Macmillan, 2009.

Warner, Marina. Alone of All Her Sex: The Myth and the Cult of Virgin Mary. London: Pan Books, 1985 (1976).

Wiesner-Hanks, Merry E. Witchcraft in Early Modern Europe (Problems in European Civilization). Boston: Cengage Learning, 2006.

Wiesner-Hanks, Merry E., and Susan Karant-Nunn. Luther on Women: A Sourcebook. Cambridge: Cambridge University Press, 2003. 


\section{4}

\section{CONCLUSIONS}

\section{Structures of experiencing gender and religion from the medieval to the early modern period}

While our conceptualisations of religion and gender as lived are based on medieval and early modern evidence, we propose they may have wider temporal applicability. While experience is always situated in time and culture, wider conceptualisations and analytical categories are required to explain and to understand the past as well as the present.

To return to the questions posed in the introduction: we asked how people performed both religion and gender in their lives in ways that appropriated some methods, persons and contexts but were rather different from what the ideologists prescribed. How can this performance be conceptualised as a lived experience of gender and religion? Most importantly, how does such a conceptualisation change the historical investigation of either religion or gender?

It is widely agreed upon that religion permeated all spheres of society and people's lives. We have divided this book to three rather traditional sections: the home, the public and the religious spheres. The home could be understood as private, although we have argued that his kind of categorisation needs to be used with care. We have aimed at its deconstruction. The public should be understood here as the shared, communal and visible rather than the official. In the third section, the religious or the sacred sphere can be understood to be opposed to the secular, but here, too, we argue that the two infused one another. All these spheres were fluid rather than fixed categories; they contributed to the construction of gender and lived religion and were also produced by gender performance and religious practices.

The home, household and family stand out as spaces where religion and gender were performed and experienced. Marriage and the household were the basic units of society, and the marriage bed and marital relationship, with their joys, sorrows and duties, largely defined ordinary people's lives. Being a wife and mother or a husband and father were roles society expected of its members, and 
parenting and taking care of the household and one's dependants were religiously prescribed positions and moral responsibilities, even when many individuals lived their lives outside those roles. Family life and religion were intertwined. Family relations and the home were essential in both religious teaching and the components of daily life. Religion and gender were lived out and experienced at home, as were political relations, economic transactions and all kinds of societal reproductions. The home was a nexus of human life, not just a sphere of intimacy and affectivity. In the medieval and early modern period, it was not as invisible as it seems now; rather it was a significant societal and political sphere of action. The emphasis on the public and the official has stressed the hierarchal and narrowing side of religion, while at home religion created a sphere and room for action depending more on contingent situational needs than categorical hierarchies.

Secular and religious values regularly supported each other and guided the construction and performance of gender. Theological theories and teaching on gender within the family were often inconsistent and even contradictory. A good wife and mother, for example, possessed the attributes of a pious Christian: she was meek and humble and obedient, but also dutiful and diligent. However, if the need arose, she was to correct her dependants. Furthermore, humility and especially self-restraint were also part of being a husband in the religious context. Religion formed the basis for family relations but also offered an option for contesting them. Therefore, even if learned ponderings generally agreed upon the gender hierarchy, they did not form one uncomplicated category of the feminine or the masculine. Obviously, the lived experiences of medieval and early modern women and men were even more multifaceted.

Since homes themselves and family structures changed slowly, their influence on religion and gender also produced slow changes. However, the Reformation ideals of marriage and motherhood were not completely new to society, nor to religion. While the Protestant Reformation's ideals lifted marriage and motherhood up as sacred, the home and the family had long been central to everyday practices of faith and piety.

Different cultural areas of Europe were, of course, not alike in every respect. Family structures varied from the southern and eastern multigenerational and sibling households to the north-western nuclear types, and they were mixed within these areas so that one can find large households in England and Scandinavia as well as individual couples with children in the Mediterranean. It is essential to understand the contingent nature of all patterns, including gender and piety: people lived in many different circumstances. Since both gender and piety were things that people did, performed and lived in connection to other people and other demands around them, things that had to be negotiated, approved and interpreted with others in a community, they were also things that could be adapted, appropriated and changed according to situational needs.

The definitions of the private changed more profoundly only with industrialisation and the creation of bourgeois culture. Today, we are again facing a 
transformation of everyday spheres: women working outside is not an automatic norm even in western societies, and the (r)evolution of work (home offices and new types of working methods) may even take working members of society back into the home, while social media has revolutionised our understanding of the private and shared. The idea of only men occupying medieval public spaces has long been repudiated, but the idea of 'true, masculine men' of the past still lives on. The media promotes the idea of clear gender stereotypes in the past: 'back then' women were feminine and men were truly men. The Middle Ages, as an imagined past, is widely used in popular imagery and an example may be seen the use of the Viking as 'a true man' in advertisements. As we have hopefully managed to show in this book, clear gender categories were not the case during the Middle Ages or early modern era; such ideas belong to the 'imagined past' and simultaneously tell something about the needs of the current society and culture. The modern world does acknowledge various gender identities and sexual variations, but a more nuanced understanding of gender has also led to a counter reaction, to a longing for clear gender roles and categorisations. As an unfortunate example, the traditional wife movement: a wife fulfilling the mid-20thcentury gender role as 'natural' has emerged. Tellingly, this vocabulary is mostly cultivated among people who also desire clearer ethnic boundaries and admire the Middle Ages as a 'white' era - i.e. the white supremacist subculture.

Ideologically, it was inappropriate for women to have public power or spend time in a public space. Nevertheless, the communal nature of pre-modern religion demanded that it as well as gender - and their interaction - were also performed in the public sphere. Furthermore, politics influenced religion, and religion was a way to participate in the field of politics. For example, pilgrimages were manifestations of devotion but simultaneously politically laden acts - they opened the floor for each member of the community to make a statement in this field. Quite often broad participation was expected and even required. The best attested examples can be found in late medieval and Renaissance Italian city-states, where pilgrimages, processions, and flagellant movements not only enabled the participation of the whole community but also helped create the very community. Collective rituals embraced both feelings of belonging to and tensions within a community, and they provided tools for the participating group to form itself as a community. The interconnection of rituals with the community was, however, an open-ended process; they were not a stable mechanism with a fixed outcome - that is, a reinforcement of existing values. The interrelatedness of these phenomena simultaneously underlines the construction of gender as an open process.

The boundaries of the private and public spheres, and the appropriate and inappropriate, were also connected to the virtues and sins promoted by the church and supported by secular courts. No single authority defined virtue and vice, honour and disgrace, or private and public. Public opinion regulated the lives of people just as much as laws, court rulings and religious teachings, and both men and women were active agents in forming public opinion. They actively defined 
what was permitted and appropriate in the community, as well as what was not permitted and not appropriate. So, instead of being the objects of restrictions dictated by common norms, women, too, participated in producing these norms. Religion was both a platform and a medium for these processes of production.

The discussions about the participation of women in the public sphere reveal a continuum. The dangers of women's public participation were already present in medieval writings, and the definition of public and private spheres and actions remained at the heart of religious teachings in the early modern period. There is a long-lasting tradition of seeing public space as morally tainting for women; it continues even today also in western societies. Most recently, the \#metoo movement has made these presumptions and categorisations globally visible.

These are structures and mechanisms of experience that gained special forms and meanings in the medieval and early modern periods. The meanings of home and family as immediate circumstances and, indeed, pre-requisites of life at the time, enforced also a domestication of faith - and gender that may have been more profound than it is now. The forms that domestication took varied between families of different status and occupation: in towns the domestic sphere was smaller and more closely defined, whereas in the country and in farming families, the domestic - or 'our' land and rights - were much broader but also less clearly defined. In the most sparsely inhabited Nordic areas, a family's private or domestic space could extend several kilometres into the forest or water area. Nevertheless, the counterpart of domestication was always publication, or the negotiating, contesting and sharing of experience, religious or gendered.

We have also discussed the mechanisms and fora of bringing about and sharing experience. Ordinary lay Christians no doubt experienced religion as something that restricted and controlled them, but it also offered them new opportunities. The church determined how religion should be practised by requiring annual confessions and penances, but it also left individuals with plenty of freedom of choice. Religion thus offered people the freedom and space to fulfil themselves and sometimes even the opportunity to take down gendered behavioural norms or promote oneself by fulfilling them. Modern scholarship often starts with the premise that breaking the confines of gender was the ultimate goal of religious advocates, or at least it was required for a religious experience to be meaningful. However, a considerable amount of evidence suggests that women were happy to emphasise fulfilling such expectations via religion. This does not mean, in our view, that women were so suppressed by the patriarchy that they did not know their own good - rather the limits of gender were wide and flexible enough to be accepted and utilised in a positive way in identity building. So, while inserting queer elements into femininity, for example in the performance of virginity, the women mystics could at the same time produce a dualistic - even complementary - gender order between the confessor and the ecstatic mystic.

Late medieval and early modern Christianity, both Protestant and Catholic, may have operated on the platform of neo-Platonic binaries that organised the world into pairs of opposites, such as black and white, light and darkness, and 
men and women, but it also seems to have flirted with paradoxical inversions of the same binaries; the performance of religion required the queering of gender. Furthermore, since the last shall be the first, it was necessary to be humble to be righteous, and to be redeemed it was necessary to confess to one's unavoidable sinfulness. This paradox led to different expressions in Protestantism and Catholicism, but it was important in both. Sin and virtue, humility and pride, and freedom and servitude to God formed binary pairs that were constantly turned upside down; they intermingled and eventually formed paradoxes in which sin and virtue could not exist without each other, humility was pride, and servitude was freedom. The identity and subjectivity of the religious self was formed in this submission to rules and the whole that was mightier than oneself. The social and cultural categories of feminine and masculine gendering featured this blurring. Gender did operate in terms of categorical binaries, but instead of strictly maintaining the neo-platonic categories, medieval and early modern Christianity continuously flirted with paradoxical inversions. Religion set the genders' asymmetric hierarchy in a continuous swinging motion. Masculinity and femininity drew on the same qualities, albeit perhaps in different situations and for different ends. To be masculine, men had to be feminine. Conversely, the same applied also to women. The social and cultural categories of the feminine and the masculine were blurred; gender was a matrix or a web of qualities that could be drawn upon by people to present themselves as religiously successful men or women.

The building bricks in this process are bodily practices both in the sense of knowing actions, like rituals as well as sensory elements, seeing, hearing, smelling, tasting and touching the religion. Correspondingly, linguistic elements were crucial in these processes. By shared narrations and memories, be they at dinner table, village well or judicial hearing, men and women were giving meaning to their religious practices and performance of gender. Significant in the process in meaning-making were also memories. Recollecting events, practices, thoughts, emotions and sensory elements with others was a way to interpret the past in order to comprehend the present and plan for the future. Not all incident or practices become memories, the insignificant ones were forgotten. And not all experiences were occurrences that actually happened; they may have been created and evoked by shared narrations of cultural patterns. Collective memories, whether in form of repeated bodily practices like pilgrimages or narrations, were a way to give meaning to events, to comprehend and control them.

Thus, gender was a performative project, but also an experience formed both the material and mental entablements, and negotiated between the individuals and their surroundings: it was something people did instead of what they were, and it was something that people qualified rather than something that qualified them. Together, gender and religion formed a performative space, a stage that empowered people to do things and qualify the ways they did them. Obviously, these performances were regulated, but medieval and early modern regulation was not the same as modern religious regulation. In the religious rituals of the 
pre-modern lay people, the gender roles that related to everyday life and livelihood for each and every status were reinforced in the sphere of the sacred. The religious experiences enforced and moulded gendered roles in the family and community, but gender also produced religious experiences and identities through shared and individual communal and bodily practices. These experiences could be restrictive, since their sharedness meant that they had to be at least partly approved of by others, but they could also be empowering and constructive, as they allowed a negotiation of individual and communal identity.

The corporeality of religious practices simultaneously turns them into gendered practices. Bodies were not only used to produce experience and religion; appropriating Saba Mahmood's and Sara Ahmed's theories, religion was also used to produce the body and its gender. Bodily performances and the experiences of the body moving and acting transform the self and allow it to pass through different normative regimes governed by different sets of formal or informal rules, norms and expectations. The body is not just something upon which religion is imposed or displayed, a receptacle or inscriptive surface for religion. Rather than merely being an outward representation or a tool, the body is an agent itself that shapes the spiritual experience of the conscious human subject.

Religion is an elaborate construction of complex and conflicting human minds, including both the somatic and the cognitive. Gender included hierarchies, but not permanently unbalanced relationships of 'power over'. It turned into a quality - or a web of qualities - that empowered people to do things in a performative project of identity.

The title of this book mentions two traditionally separate periods of time, and it seems relevant to return to the question period boundaries. The religious changes that took place in the early modern period due to the Protestant and Catholic Reformations are often considered to have confined women more closely to their homes. In discussing women's public actions in medieval and early modern communities, we should bear in mind that the line between private and public as we understand it now was not created until in the bourgeois culture of the 19th century. In previous centuries, public and private had different definitions. In a wider historical context, confining women to the home has been a longue durée tradition especially prevalent in the Mediterranean from Antiquity on - it is not an exclusive element of Islamic societies.

In medieval and early modern ideologies, lay people were not permitted to guide the spiritual sphere, despite the Reformation rhetoric of the priesthood of all believers. In practice, however, most of the religious rituals that marked parish life both before and after the Reformations were performed by lay men and women. Furthermore, the clergy itself had difficulties in drawing the line between the virtuous, saints, sinners, heretics and demoniacs. The Reformation era, if anything, added to the confusion, and led to hesitation over proper belief, ritual and sacraments.

In this volume, we have looked at religion and gender as experience, and at experience and history as communicative and intersubjective processes of 
entanglement. Religion as experience is created by intersectionality; it creates a holistic account that includes both the cognitive and the somatic, as well as the spiritual, social and cultural.

It is evident to us, that things lived and experienced are at the same time more flexible to adaptation and slower to profound change than any of the written analyses of these changes - either by contemporaries or by later sociologists or historians - are apt to show. The lived and experienced are at the same time rooted in the momentary, contingent and changing situation, and in the basics of life, society and survival. They change radically only when the living conditions of people change equally radically.

The medieval era proceeded from one process of change to the next; it was not a stagnant time period. However, at the crossing to the early modern period, new kinds of wealth, innovation and disease entered the European universe. However, most of the basic modes of life nevertheless remained the same in the agricultural milieu and even in the mostly small towns' inherently rural conditions. The changes in family structure were slow, the range of occupations to provide livelihoods remained the same for most people, even though markets changed considerably with the globalisation of the early modern world. The inherent uncertainty of life and death under the fluctuations of politics, economics, markets, weather, disease and other things that could, for a long time to come only be explained as God's Wrath and managed by keeping God content stayed the same - or became even more uncertain - through the periods in question. In fact, it seems evident that the very fastness of the changes in political, economic and natural conditions of life led to people clinging to their old values, modes of faith and habits that had provided if not safety, at least comfort before. The haste of change in some spheres of life created inertia and perhaps stubborn slothfulness in others.

The pace of changes in the world from around the Millennium to 2020 seem to imply a similar nostalgic drive towards social and cultural conservatism, despite the fact that it's comforting safety is likely to be as completely false as it's traditionality is. Indeed, if we look at history, the things that conservative populist movements now see as 'traditional', or even 'natural', seem to have led the world far from safety. As one looks even deeper into longue durée history, they have only been traditional or dominant for a very short while. 


\section{INDEX}

Aachen 17, 82

Abraham Achrenius 108

Adam 7-8

Adam Schirreve 26, 28-29, 31, 32, 34

affectivity 9, 33, 98, 103, 122, 144; see also emotion

Albert of Mecklenburg 81

Ancona 17, 69

Andreuctia 70-71

Andriola (daughter of Cathalina) 67, 69

Angela of Foligno 103

Angelucia 30

Anna 105

Anna Bengtsdotter 118

Antti Skräddare 48, 52

Apps, Lara 115

Ariés, Philippe 27-28

Arnoldus (a priest) 113-114

ascetic, ascetism 8-9, 67-69, 79, 84-85, 89, 99, 101-103, 108, 109, 125-126

Augustine of Hippo 110

authority 9, 30-35, 36-37, 39, 41, 44, $46-47,50-52,73,79,82,86,88-89$, $102,125,145$

Avignon 17

Bartholoctus 70

Beatrice (a nun) 98-99

Beguines 10, 103

benandanti 110, 113

Bennett, Judith 6

Bentivenga da Gubbio 109

Berend Tappain 75, 76-77
Bible 7, 41, 87, 105, 110, 126

Blåkulla 117, 118

body 2, 8-9, 27-28, 37, 39, 40, 41, 51, $66,72,80,81,83,89,98,100-102$, 104-105, 108-109, 111, 112, 118, 122-125, 127-129, 147-148; see also corporeality

Boniacobus 30

Brauner, Sigrid 120

Brita from Engeby 117

Brita Palm 42-43

Butler, Judith 7, 127, 128

Bynum, Caroline Walker 124

Caciola, Nancy 109

Caesar of Heisterbach x, 37-38, 98-99, 113-114

Calvinists 15, 73

canonisation process $\mathrm{x}, \mathrm{xi}, 18-19,32,33$, $34,68,69,70,81,82,99,100,104,109$

Carmelite Reform 104, 106

Cathalina (a pilgrim) 67, 68-69

Catherine of Siena 103

Catherine of Sweden xi

Catholic/Catholics xi, 19, 38, 42, 53, 65, 66, $72,73,75,83,86-88,104,105-108,110$, $112,113,123,124,126-127,146-148$

Cecca 71

Ceccholus 99

Cecilia Schirreve 26, 27-29, 31, 32

celibacy 17, 30, 35, 36, 80, 83, 100, 114

charity $68,107,125$

Charles of Blois x, 71 
chastity 9, 35, 42, 80, 100, 106, 107

Cherubino of Siena 39-40

Chojnacki, Stanley 44, 45

Christmas 75

Cistersians 9, 103

Clark, Stuart 119

Cohn, Norman 113

Company of the Most Blessed Sacrament 106

Corinthians 37

corporeality 8, 9, 12, 39, 75, 89, 100, 101, $121,124,129,148$; see also body

Corpus Christi 75

Council of Trent xi, 104, 106

dancing 26, 27, 75

Daughters of Charity 108

demonic possession $19,72,82,102$, 108-110

Devil 7, 19, 26, 72, 101, 108-115, 117, 118-119, 127

Dialogue on Miracles 114

Diomisia 28

Discalded Carmelites xi, 105, 106

Dixon, Scott, C. 78

Dordi Matintytär 25, 45-49, 50, 52

drink (beer, wine) 26, 40, 75-76, 78, 115, $121,122,123$

Easter 75, 87

Ebba (Mats Henrickson's widow) 118

Ecstasy of Teresa 105

Ecstatic Pietism 108

Elliott, Dyan 102, 113

emotion 2, 4, 5, 7, 9-10, 12, 13, 27-28, $31,35,37,40,44,50,52,99,103-104$, 122-123, 124, 125, 147; see also affectivity

England xi, 12, 16, 54, 84, 124, 144

Europe x, xi, 10, 14-16, 17, 34, 42, 43, $45,54,68,71,75,76,77,86,88$, 103, 107, 110, 112, 115-116, 117, $120,144,149$

Eve 7-8, 98

experience: as an analytical concept $10,11-16,13 n 30,52-54,85,88-89$, 101-102, 122-124, 127-129, 143-144, 146-149; etymology of 12-13

family $13,16-18,25,26,28-35,36-37$, $39-42,44-45,46-48,50,52,53-54$, $65,66,68,69,70,71,73-74,77$, 78-79, 83, 86, 88, 104, 105, 106, 110, $125,128,143-144,146,148,149$

Farmer, Sharon 71 father/fatherhood 10, 17, 18, 26, 29, 30, $31,33,34-35,36,37,44,46,47,48$, 49-50, 52, 53, 68, 77, 79, 84, 114, 143 feast day/saint's day 75, 76, 77, 78, 101 Feast of Invention of the Holy Cross 75 Finland xi, 16, 25, 41, 42, 45, 47, 51, 66, $75,77,84,85,107-108,116,117,122$, 125

food 41, 51, 73, 77, 85, 101, 121, 125; see also meal

France xi, 38, 42, 72-73, 106, 108, 116, 117

German Peasants' War xi, 86

Gervasius (father of Rogerus) 34

Ghibellines 69

Gianlorenzo Bernini 105

Ginzburg, Carlo 113

Gospel of Matthew 35

Gow, Andrew 115

Gratian 19

Gudwasti 34

Guelphs 69

Guincamp 17, 71

Gustav Vasa xi, 12

Hall, David 3

Hannah 105

Hans Smek (a knight) 19, 81-82, 86, 108

Heikki Jankcari 45-50, 52

Henry VIII xi, 12

Herlihy, David 43-44

Heuser, Peter 117

household 5-6, 10, 17-18, 25, 31, 33, $36-37,39,40,41,46-48,50-51,52$, $54,66,73,74,75,76,77-80,89,105$, $143-144$

Huguenots 73

Ii 84

incubus 113, 114

intercourse 41, 45-47, 52, 79, 112, 113, 115

invocation $34,35,67$

Islam 105, 120, 127, 148

Italy 16, 29, 39, 43-45, 68-70, 109

ius commune 70

Jääski 17, 75, 76, 78, 125

Jansenism 106

Jean Bodin 119

Jesuits 83, 85, 106

Jews 104, 110

Johanna Schirreve (a 5-year-old) 18, 25-32 
Johanna Wase (little Johanna's godmother) 26-27

Johannes (Johanna's brother) 32

Johannes de la Wyle 26, 27, 29

Johannes de Pirebok 27

Johannes Nieder 114

Johannes Piscatoris 28

Joseph xi, 19, 104

Juha Ristonpoika 46-48, 49, 52

Karin Persdotter 117, 118-119

Karras, Ruth Mazo 80, 83

Katerina 34

Käthe 105

Kelly, Joan 15

Klapisch-Zuber, Christiane 44, 45

Late Antiquity 35, 80, 100, 103, 105, 110

Leon Battista Alberti 35

Lett, Didier 69

Levack, Brian 115

Liisa Eerikintytär 108

Lisbetta (from Sund) 118-119

Litany of the Saints prayer 75

Luther, Martin xi, 10, 50-51, 74, 83, 86, 105-106, 119, 120, 122

Lutherans 43, 73, 75, 83, 85, 122-123, 124

magic 4, 78, 81, 110-113, 116-121, 123-125

Mahmood, Saba 124, 148

maleficium 113, 121

Malleus Maleficarum xi, 112

Manfredus (a two-year-old) 30

Marches 69

Marden (village) 17, 26

Maria from Engeby 117

Maria from Ulvila 18

Maria Nilsdotter 117-118

Maria Pertuntytär Sawo 45-46, 48-52

Mary Magdalene 87, 105, 126

Mats Pålsson 118

McGuire, Meredith 3

McNamer, Sarah 103, 124

meal 76, 78, 101, 123; see also food

Melanchton 83

memory 12, 30, 32, 82, 111, 147

Ménagier of Paris 73-74

Midelfort, Erik 116

Mikko (Brother of Dordi) 47-48, 49

miracle 17, 18, 26, 28-30, 32, 34, 68, 69, $70-73,77,81-82,87,89,99,104$

missionaries, missionary work 85, 105, 106 Mitigated convent 105
Montefalco 17, 70, 101, 109

mother/motherhood 7, 10, 17-19, 27-31, $33-34,35,36,39,44,45-49,50-53$, 67-68, 70, 74, 77, 83, 97, 98-101, 104, 106, 143-144

Murray, Jacqueline 80

Muslims 110

mysticism 9, 80, 87, 99-100, 102-106, 108-109, 113, 121-122, 124-126, 146

Nanczus (son of Cathalina) 67

narration 7, 19, 25, 28, 32, 34, 74, 80, $82,83,101,102,110,112,113,114$, 118-119, 147

nature, natural 33, 128, 145, 149

Nenonen, Marko 121

Newman, Barbara 109

Nicholas Piscatoris 28

Nicole Orby 72-73

Opitz-Belakhal, Claudia 119

Orsi, Robert 3

Oulu 84

parent, parenthood 3, 17-18, 25, 27-35, $37,42,44,45,49-50,51,106,107,114$, 144

Paul 37, 86

Penitents 103, 107

Per Christersson Broberg 42-43

Perttu Laurinpoika Sawo 46-50, 52

Pietism/Pietists xi, 83-84, 85, 89, 107-108

pilgrim/pilgrimages 4, 18-19, 29, 32, 34, $65,66-69,71,77,82,83,87,89,97$, $106,126,145,147$

Pope 15, 37, 69, 104, 107, 110

Pope John XXII 69

Pope Pius IV 104

prayer $34,41,46,65,68,73,74,75,76$, 78, 99, 101, 103, 104, 107, 114, 119, 122-124, 127

Psilander, Nils 118

Pylkkänen, Anu 41

Restored convent 105

Risto (Father of Juha) 47-48

Rogation Days 75

Rogerus (Diomisia's son) 28, 34

Rome 17, 81, 100

Roper, Lyndal 51, 74, 115, 117

sacrament $35,42,73,106,110,112,148$

sacred $4,53,66-67,79,82,83,87,89$,

$110,123,126,127,128,143-144,148$ 
Saint Birgitta x, 19, 34, 81-83, 101, 127, 128

Saint Catherine of Alexandria 75-76

Saint Clare of Montefalco x, 70-71, 99-104, 109, 127

Saint George 25, 76

Saint Nicholas of Tolentino x, 30, 67, 69 Saint Olaf 76

saint/sanctity x, xi, 5, 19, 25, 26, 28-32, 34-35, 37, 66-72, 75-78, 81-83, 86, 87, 89, 97-104, 109, 110, 127, 128, 148

Saints' Day festivities xi, 75-78

Saint Teresa of Ávila (also called Saint Teresa of Jesus) xi, 104-105, 106

Saint Thomas (also called Thomas Cantilupe) x, 18, 25-26, 29-32, 34

Schäfer, Petter 84-85

Schulte, Rolf 115, 120

Scott, Joan 6, 12

sex 8, 9, 19, 35-37, 41-43, 46, 52, 72, 79, 80, 82, 100, 101, 111-115, 117; biological 7, 10, 36, 39, 79, 115-116, $119,120,123,126-127$; orientation 9, 10, 15, 80, 102, 145; roles 83, 105, 115, 117, 118, 119, 123; see also intercourse

Shepard, Alexandra 35, 36, 79

Simmons, Patricia 36

$\sin 4,5,8,29,35,37-38,39,51,72,75$, $79,80,81,82-83,85,88,97,98-101$, 104, 108, 110-111, 114, 121, 123, 126, 127-128, 145, 147, 148

Smedjegård 84

Society of Jesus 106

Spain 104

Spener, Philipp Jakob 84, 107

Stark, Laura 43

Stedman Jones, Gareth 12

Stephens, Walter 112

succubus 114 superstition 4, 5, 72, 75, 81, 116, 122, 123

Sweden x, xi, 12, 34, 40-42, 44, 74, 77, $81,84,108,111,117-118,120,128$

Swenonis 34

Theophilus 110

Thomas Aquinas 111

Thomas Boni de Fulcioneo 109

Thomas Schonk (father of Johannes) 26-27

Tuomas Pullinen 75

Turku 17, 42, 84-85, 117

Ulstadius, Laurentius Andears 84-85, 107

Umbria 70

Ursulines 106

Vadstena $17,34,81-83$

violence $39-43,49,71-72,80$

virginity $9,30,35-36,80,83,98-101$, $113,126,128,146$

Virgin Mary 9, 19, 36, 49, 50, 76, 87, 98-99, 103, 105, 122, 125

virtue $7,9,39,49,53,80,85,88,100$, 102, 103, 106, 113, 126-128, 145, 147

Voltmer, Rita 117

votive offering 69,97

Walterus de la Wyle 26

Wargentin, Anna 85

widow 10, 19, 31, 35, 37, 44-45, 74, 118

Wiesner-Hanks, Merry 74, 120

witchcraft 5, 17, 18, 19, 47-49, 51-52, 98, 102, 109-121

work 1, 5-6, 7, 16-17, 18, 29, 31, 33, 36, $43,45,49,51,71,75,77,78,107,120$, 121,145

Zona Ricii 67 


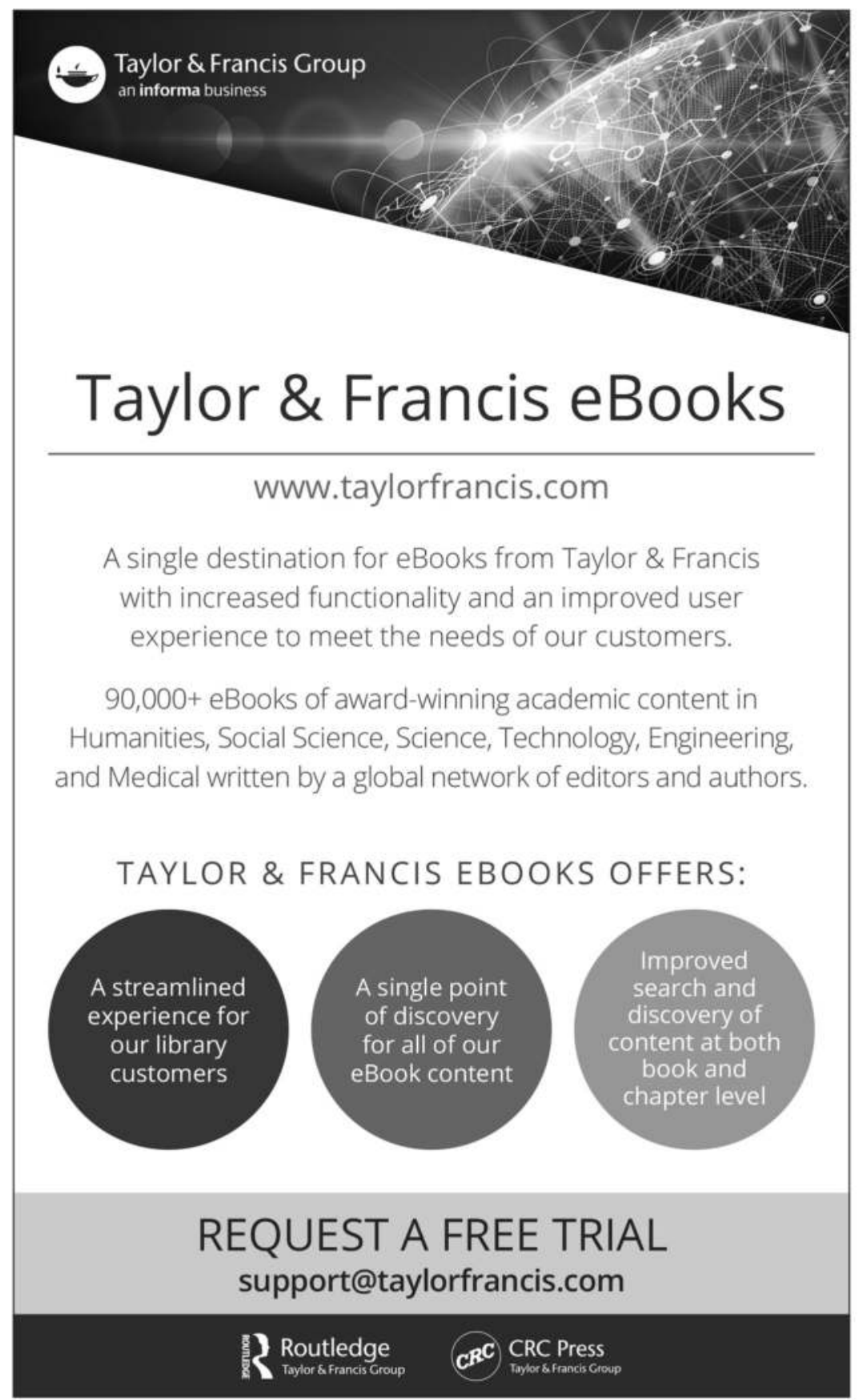

